Historic, archived document

Do not assume content reflects current scientific knowledge, policies, or practices. 



\section{厄.A RD.}

The consolidation announced one year ago of the firms of Joseph Breck \& Sons and Parker d Wood into the Joseph Brect: \& Sons (Corporation) has proved very sutisfactory. The reduction of expenses made by operating both concerns under one management enables us to serve our customers on a smaller margin of profit than could be done by either of the old firms, and we have not only held the business of both houses, but in some months the business of the Corporation exceeded the combined business of the old fims for the corresponding months of 1892 very considerably.

Our only regret is that owing to a demand far beyond our expectations our facilities for a while were inndequate for handling the business, and thereby some of our customer's were disappointed through not receiving their goods as promptly as could be wished. We take this opportunity to apologize to each one of our friends who was discommoded in this way.

We believe our arrengements reve now so complete thrt there will be no cause for complaint in the future, and that no house in the country is better prepared to give its patrons mompt and efficient service than we rre.

We are thankful for the generous patrouage heretrofore given, and intend to continue to merit the same by exercising the ntmost care and fidelity in promoting the interests of our customers.

47 to 54 No. Market St., 46 Merchants Row, and 17 to 19 North St.,

BOSTON, MASS.

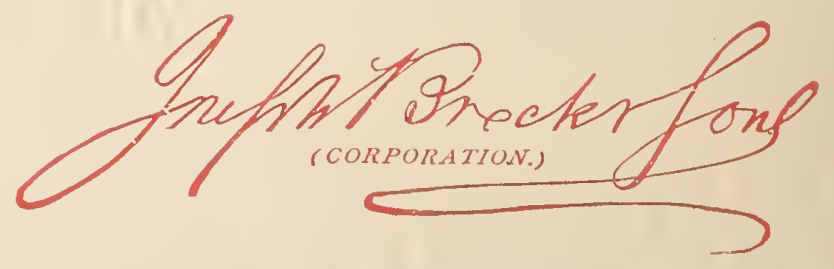




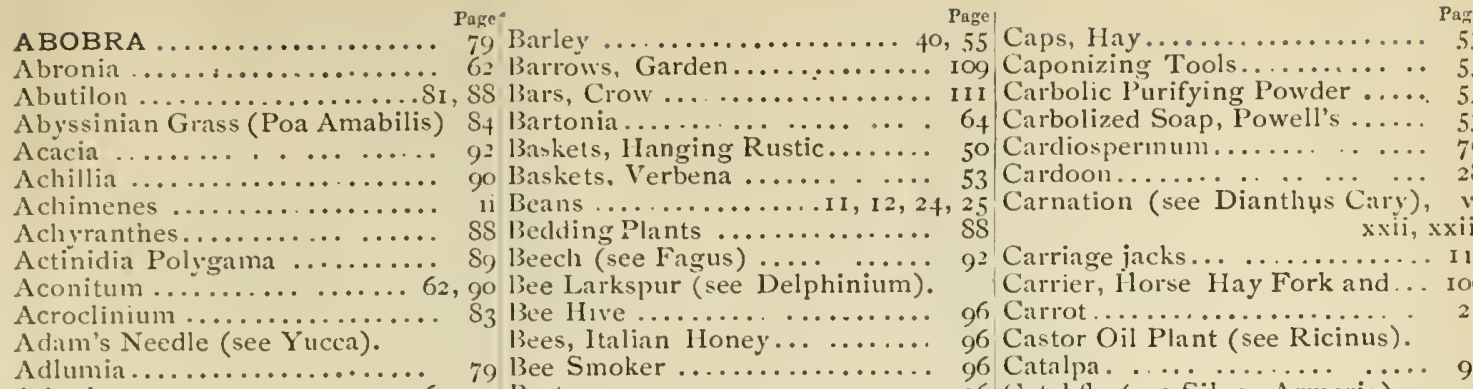

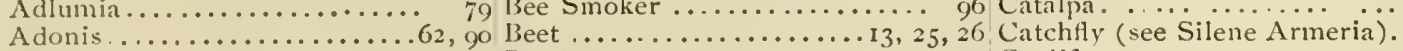

Esculus ................ 92 Beetles ................111 Cauliflower .......... . $4,2 S, 40$

African Rose (see Hibiscus). Begonia... .........ii, xiii, 8 I, S8 Celastrus Scandens........... \&9

Agapanthus ................ xvi Bell Flower (see Wahlenbergia). |Celery ............... $3,2 S, 40$

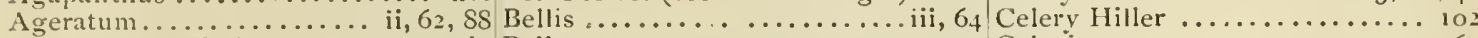

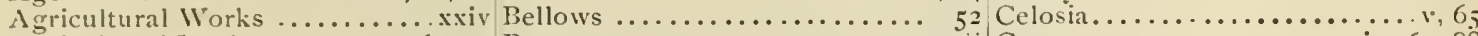

Agricultural Implements .... $0^{6,112}$ Bessera .................. xvii Centaurea.............. . . 65, sS

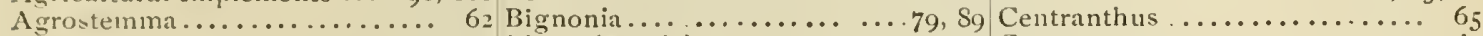

Agrostis................. $\delta_{3}$ Birch (Betula) ............ 92 Centrosema ............ iv

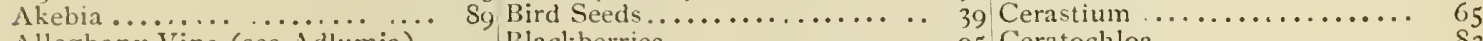

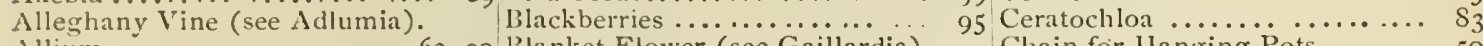

Allium ..............62, 90 Blanket Flower (see Gaillardia).

Almond, Flowering . ........... Sg Bleeding Ileart (see Dicentra).

Alonsoa ................ 62 Block, Sure Grip Steel Tackle.

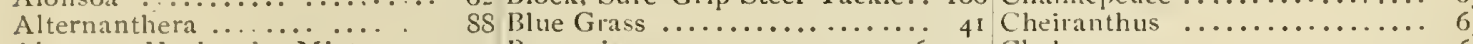

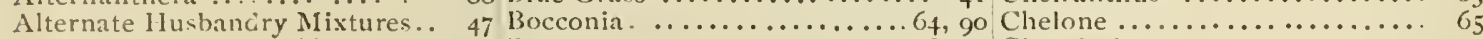

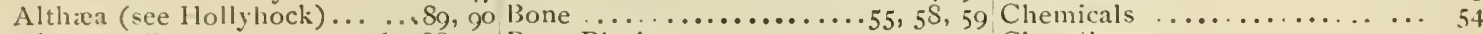

Alyssum, Sweet ....... $62,88,90$ Bone Black ............. 54 Chervil ............... 39

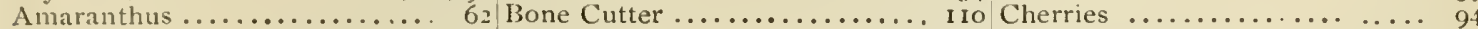

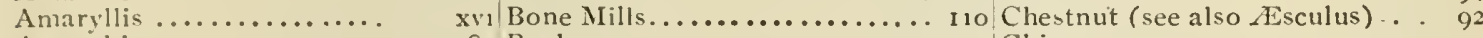

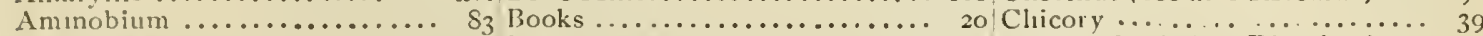

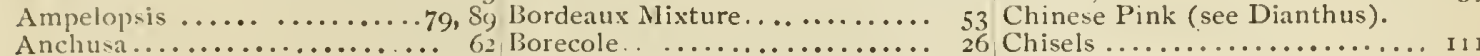

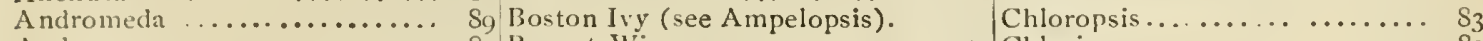

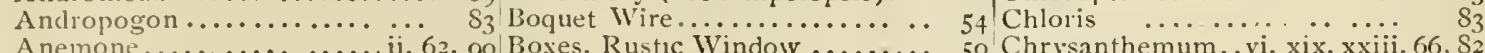

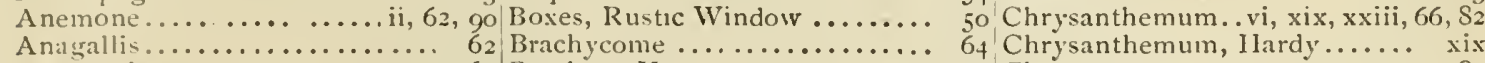

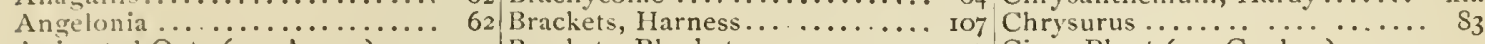

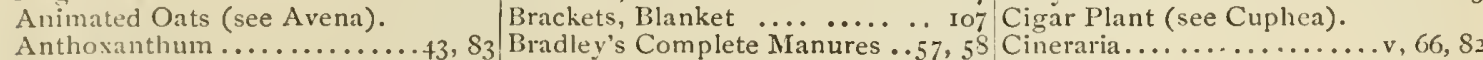

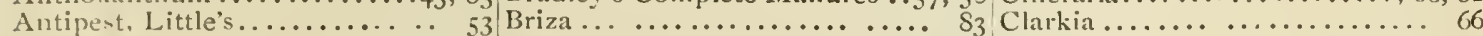

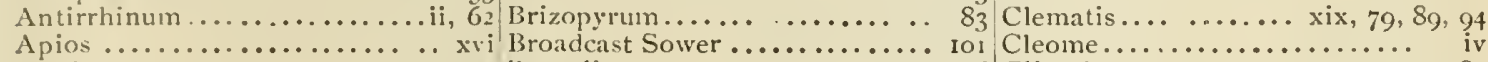

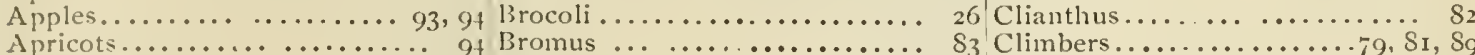

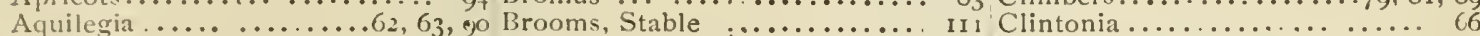

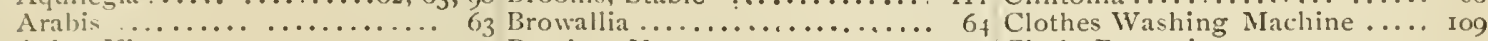

Arbor Vitx................ 91, 92 Brushes, Ilorse ............. I I I Cloth, Protecting ........... 54

Arctotis ............... 63 Brussels Sprouts ........... 26 Clover ..............15,4t

Argemone ................ $\sigma_{3}$ Buckthorn................. $9_{2}^{2}$ Coba................., so, SS

Arica Lutescens .............xxiv Buckwheat ............. to, 55 Coccinea ............... So

Aristolochia $\ldots \ldots \ldots \ldots \ldots \ldots \ldots$. 79 Burea of Registry and Informa- ${ }_{22}$ Cockscomb (see Celosia).

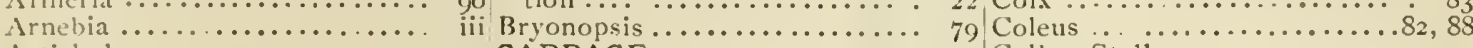

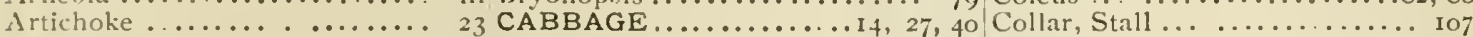

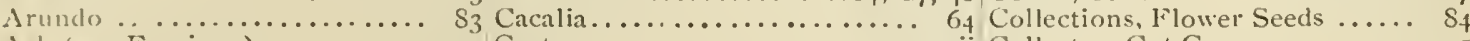

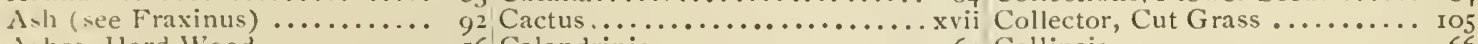

A 4 hes, 11 ard Wood........... 56 Calandrinia.............. 64 Collinsia ...............6 66

Asparagus ...............23, to Caladium................

Asparagus Plumosus .......... ii Calceolaria.................... si Columbine (see Aquilega).

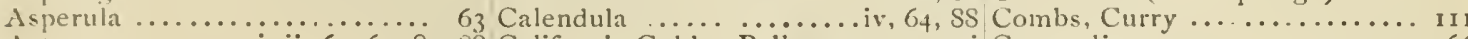

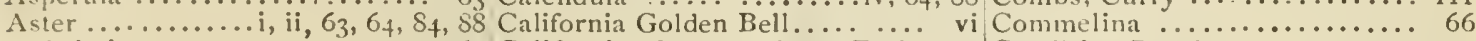

Aubrietia................ $6_{3}$ California Poppy (see Esch- Condition Powder............ 55

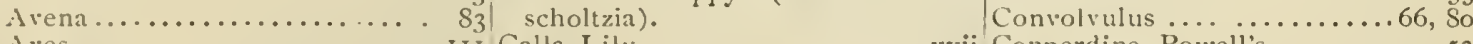

Axes .................. II I Calla Lily ............. xvii Copperdine, Powell's........ 53

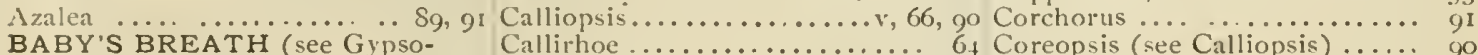

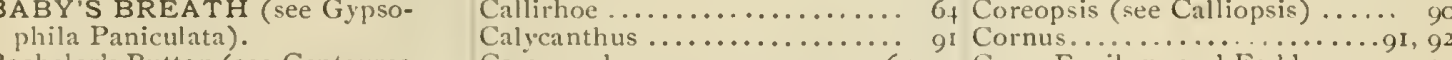

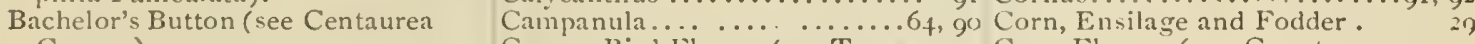
Ci:anus).

Balloon Vine (see Cardiospermum).

Balsam (see Impatiens Balsam. ina).

Canary Bird Flower (see Tropacluin).

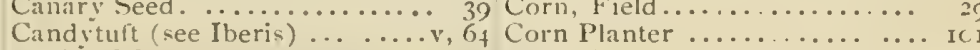

Canker Worm Exterminator.... 53 Corn, Pop.................. 29

Banticia .

$6+$ Canna .....................iii, 65, SS Corn, Sweet.

Barberry................. 92 Canterbury Bells (see Campanula). Corn Salad 
INDEX.

Page

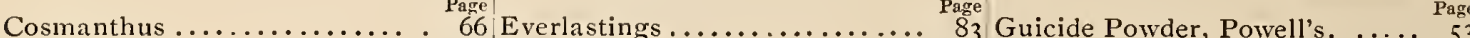

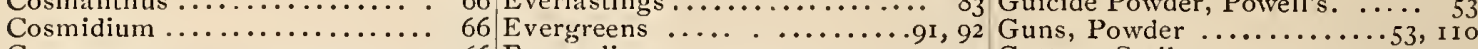

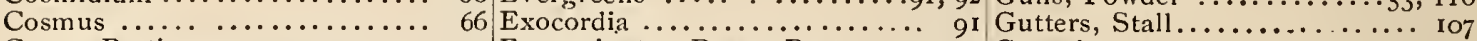

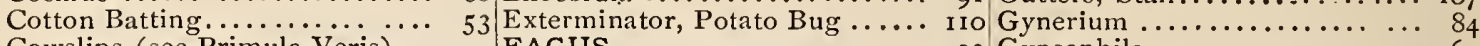

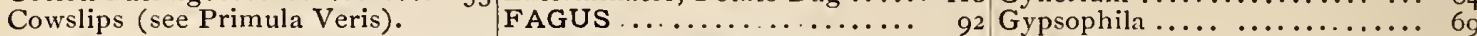

Cress.................. 30 False Indigo (see Baptisia). HAMMERS .............. III

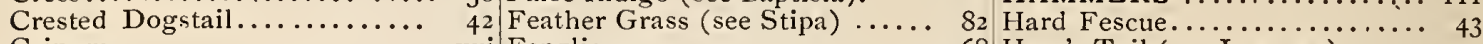

Crinum................. xvil Fenzlia ............... 68 Hare's Tail (see Laguras).

Crow Bars . . .............. I I I Fern, Sward ... ........... xxiv Harrow, Eleven Tooth ....... I02

Crucianelle ............... 66 Fertilizer Drill.............. ro3 Harrow, Morgan Spading ...... 99

Cucumber ............... 15, 30 Fertilizers .......54, 56, 57, 58, 59 Harrow, Planet, Jr. .......... I02

Cucumis ................. 8o Festuca ................. 82, 84 Harrow, Revisible Smoothing ... 99

Cucurbita................ So Fever and Ague (see Eucalyp- Harow, Spring Tooth .... .... I00

Cultirators.............. 102, I03 tus). Hatchet, Ice................ 11 1

Cuphea.................. 82,88 Feverfew (see Pyrethrum) $\ldots . .72,88$ Hawthorn $\ldots \ldots \ldots \ldots \ldots \ldots . . . . .62$

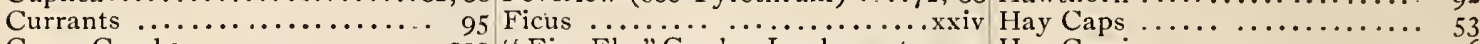

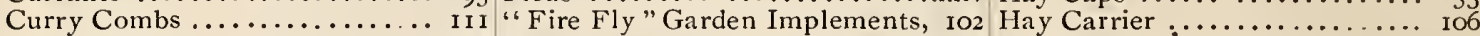

Cutter, Bone.............. I Io Firs ................. 9ा Headers, Barrel............. II

Cutters, Sod................ I I I Fish, Desiccated.............. 55 Heart's Ease (see Viola Tricolor).

Cuttle-Fish Bone........... 39 Flails ................ II I Hedge Plants............. 92

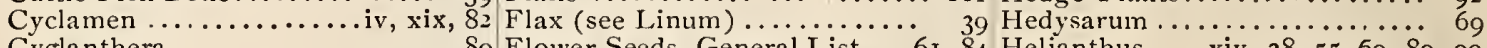

Cyclanthera .............. So Flower Seeds, General List....6r, 84 Helianthus ... .xiv, $38,55,69,89,90$

Cyclobothra ............... xvii Flowering Plum (see Prunus).

Cypress Vine (see Ipomæa). Flowering Sage (see Salvia).

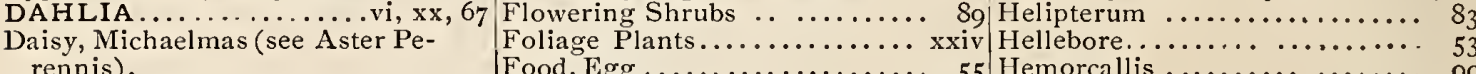

Daisy (see Bellis)

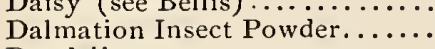

Dandelion

Daphne

Datura

Day Lily (see Funkia).

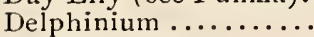

Foliage Plants...............

iii Food, Mocking-Bird......... 39 Hemp Seed ................. 39

53 Food, Parrot .............. 39 Herbaceous Plants ............ 99

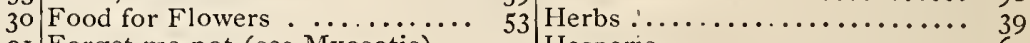

91 Forget-me-not (see Myosotis). $\quad 53$ Hesperis................... 69

67 Forks, Horse Hay .......... ro 6 Heuchera ............... vii

Forks, Garden .............. I I I Hibiscus................. 69

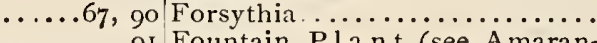

Devil-in-the-Bush (see Nigella).

Dew Plant (see Mesembryanthemum).

91 Fountain Plant (see Amaran. thus).

Four O'Clock (see Mirabilis).

Dianthus.............. 67 , 9o Foxglove (see Digitalis).

Dibbles.

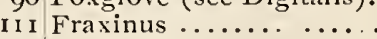

Dicentra

go Fruit Trees

91 Hiller, Celery.............. 102

Hoes, Garden.......... I03, i i 1 , i 18

Hoes, wheel .............. 102, 103

Hollyhocks.......... viii, $70,84,95$

42 Honesty (see Lunaria).

Honeysuckle.............. 80

92 Hooks...................... 118

93 Hop $\ldots \ldots \ldots \ldots \ldots \ldots \ldots \ldots \ldots \ldots \ldots \ldots \ldots$ vij

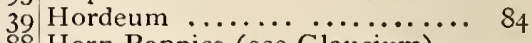

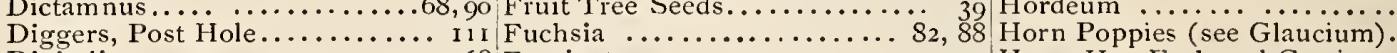

Digitalis ................. 68 Fumigators $\ldots \ldots \ldots \ldots \ldots \ldots$ I I Horse Hay Fork and Carrier.... Io6

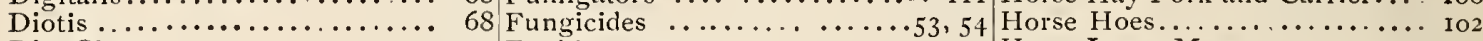

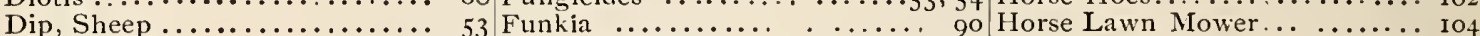

Dodecatheon................ vi GAILLARDIA

Dolichos.

Dogs, Cant

Dogwood (see Cornus).

Dracena

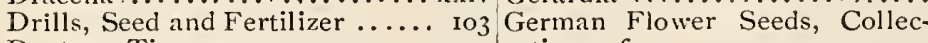

Dusters, Tin

Dusty Miller (see Centaurea).

Dutchman's Pipe (see Aristolochia).

\section{ECCREMOCARPUS}

Echeveria...

Edger Gras
Egg Plant

Egg Producer.

Elder ..............

Eleusine

Elichrysum (see Helichrysum)

Elm (Ulmus)

Emmanthe

Emulsion, Power Kerosene ....

Endive .....

Erianthus

Ervsimum

Eschscholtzia

Eucalyptus

Eulalia

Euonymus Radicans

Eupatorium.

Euphorbia

Eutoca

Evening Primrose (see CEnothera).
53 tions of .

Geum ...

Gilly Flower (see Mathiola)

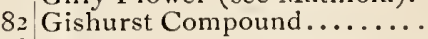

68 Gladioli

103, I I Glaucium...

40 Globe Amaranth (see Gom-

9I Gloxinia

9I Godetia

83 Golden Bell (see Forsythia). Golden Feather (see Pyrethrum).

92 Golden Tuft .

vi Gomphrena.

53 Gooseberries.

31 Gourds (see Cucurbita) .........

83 Grain

83 Grammanthes

68, 90 Grape Dust..

68 Grass Collecto

83 Grasses, Agricultural

89 Grasses, Prices of..

90 Grasses, Ornamental .

68, go Greenhouse Requisite
68 Grubbers, Daisy ....

Guano

Guaranty
55 phrena).

68 Horse Radish, Sets. ......... 40

I, 1 I 2 Hose ..................... ros

68, go Hose Nozzles ............... 1 108

82, \&s Humea ................... 82

vii Humulus ............... vii

Hungarian ................. 44

8. Hyacinth Bean (see Dolichos).

68 Hyacinthus Candicans .......x.i, 9o

69 Hydrangea ................. $9^{1}$ IBERIS (Candytuft) ...........

53 Ice Plant (see Mesembryanthe-

xi mum).

69 Impatiens (Balsam)......... 70

Indian Cress (See Nasturtium).. 33

Indian Pink (see Dianthus).

82 Indian Shot (see Canna).

69 Ink, Tree.................. 53

Insecticides...............53, 54

Insect Powder............... 53

90 Ipomá. ................... so

$S_{3}$ Iris . . . . . . . . . . . . . . xxi

95 Isolepsis . ................. S $_{4}$

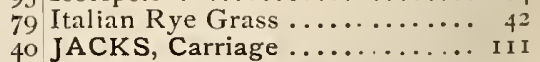

69 Jacob's Ladder (see Polemoni-

53 um).

95 Jacobra (see Senicio).

I0 5 Job's Tears (see Coix).
41,48 Joseph's Coat (see Amaranthus).

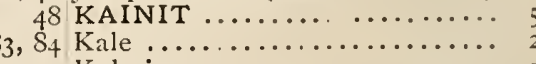

I I 1 Kalmia $\ldots \ldots \ldots \ldots \ldots \ldots \ldots \ldots 9^{1}$

I 1 Kaulfussia ................. 70

56 Kenilworth Ivy (see Linaria).

ro Kentia ................. xxiv 
Rage Pag

Reseda.................. P. 75 Spergula ...............

Restorer, Song ........... 39 Sphenogyne ..............

Retinospora.

Rhodanthe $\ldots \ldots \ldots \ldots \ldots \ldots \ldots \ldots$

Rhode Island Bent Grass .......

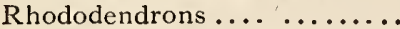

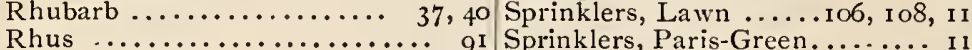
92 Spinach

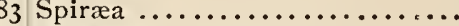

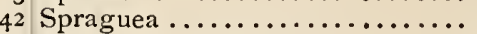

9I Spring Tooth Harrow ..........

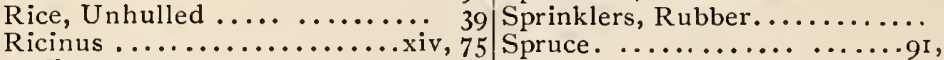

Roffea................. 54 Squash .................. I

Rollers, Garden ............ Iog Squirrel-Tail Grass (see Hordi-

Rose, Campion (see Agrostem$\mathrm{ma})$.

Roses, General Assortment...85,

Rose of Heaven (see Agrostem$\mathrm{ma}$ ).

Rose of Sharon (see Althaa).

Rough-Stalked Meadow Grass .

Roup Pills.

Ruta Baga...

Rustic Work

\section{SABBATIA}

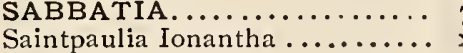

Salix................... 93

Salpiglossis ................

Salsify

Salvia...

Sanvitalia...

Saponaria

Saucers, Flower-Pot.

Saws, Pruning.............. I

Scabiosa ..........................

Schizopetalon

Schypanthus

Scissors, Flori

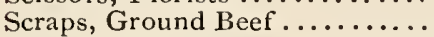

Scythes, Lawn ............... I I

Scythe Snaths ............. I I 2

Scythe Stones ............. I 2

Sedum $\ldots \ldots \ldots \ldots \ldots \ldots \ldots \ldots \ldots$. ${ }^{6}$, 90

Seed drills................. I

Sempervivum .............

Senico

Sensitive Plant (See Mimosa).

Settees, Rustic..............

Shade-Trees...............92, 93

Shears

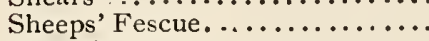

Sheep Manure

Shell Flower (see Molucella)

Shells, Ground Oyster....

Shovels

Shrubs

Silene

Silk Vine (see Peripoloca)

Slug Shot ....

Small Fruits.

Smilax (see Myrsiphyllum).

Smoke-Tree (see Rhus).

Smoker, Bee

Snake Cucumber (see Tricosanthes).

Snowball (Viburnum).

Snapdragon (see Antirrhinum).

Snowdrop-Tree (see Halesia).

Snow-on-the-Mountain (see Euphorbia).

Soap, Powell's Carbolized .....

Soap, Tobacco.

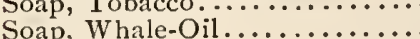

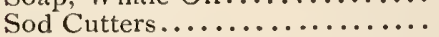

Solanum.

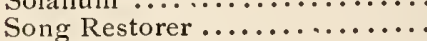

Sorbus ....................

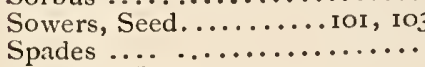

Spading Harrow ..........

Speedwell (see Veronica).

Swan River Daisy (see Brachy-
90
76

50 Sweet Rocket (see Hesperis).

93 Sweet Sultan (see Centaurea)...

43 Sweet William (see Dianthus).

56 Syringa

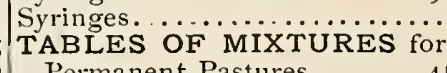

80 Tables of Mixtures for Perma-

${ }_{76}^{8}$ Tables of Mixtures for PermaHusbandry

4 Table Showing Time of Flower-

5 ing of Grasses

Tackle Block, Sure Grip Steel ..

Tagetes.................... . . . . . . .

91 Tall Meadow Oat Grass .........

Tares....................

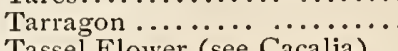

Tassel Flower (see Cacalia).

53 Thistle, Fishbone (see Chamæ.

54 peuce).

54 Thrift (see Armeria).

I I Thunbergia ................

76 Timothy.

39 Tinfoil

$9^{2}$ Tobacco ...................

12 Tobacco Dust...............

99 Tobacco Stems . . . . . . . . . . . . .

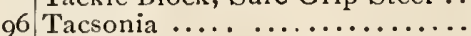

2 Tobacco Soap..............

Page

76 Tomato $\ldots \ldots \ldots \ldots \ldots \ldots . . . . .38$, 40

76 Tongs, Ice................ I I 2

37 Torch, Asbestos ............. I Io

91 Torenia .................. 77

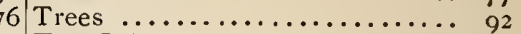

Tree Ink................. 53

2 Trellises................51, 52

Tricholæna............... 84

52 Tricosanthes............... 8

2 Trifolium $\ldots \ldots \ldots \ldots \ldots \ldots \ldots \ldots 77$

Trillium ............... 90

Tripsacum $\ldots \ldots \ldots \ldots \ldots \ldots \ldots 7,8_{4}$

Tritoma ................ 77

Stable Fittings....... ...... Io Tritonia ................ 77

Stachys................. 76 Trollius .................. 77

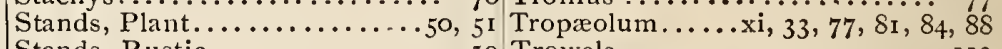

Stands, Rustic............. 5o Trowels ................ I I 2

Statice ................. 76 Truck, Barrel............... 109

42 Stellaria .................. $7^{6}$ Trumpet Flower (see Datura).

55 Stevia .................. 82 Trumpet Vine (see Bignonia).

39 Sticks, Plant ............ 5 I Tubs, Plant.............. 5 I

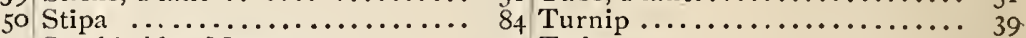

40 Stockbridge Manures. . . . . . 59 Twine.................... 54

75 Stocks (see Mathiola).... xiv, 7 I, 72, UMBILICUS ............ 77

84,88 Uniola $\ldots \ldots \ldots \ldots \ldots . \ldots \ldots$

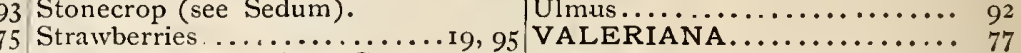

37 Strawberly-Tree (see Calycan- Vases, Rustic............... 50. thus). $\quad$ Vegetable Plants and Roots .... 40.

76 Streptocarpus...... ....... xv Vegetable Seeds, General list of, II,

76 Sturtevant's Lawn Dressing .... 56 . 56

50 Sulky Plow ............... 97 Venidium ................ 77

2 Sulphate Ammonia ......... 54 Venus'-Looking-glass (see Cam-

54 panula).

76 Sulpho Steatite Powder, Powell's, 53 Verbena............xv, 77, 78, 88

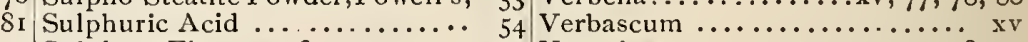

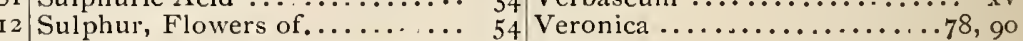

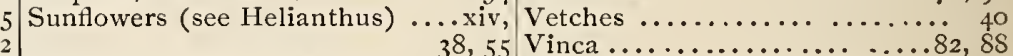

Superphosphates, Bradley's . .57, 59 Viola ........................ $78,84,88$

2 Supplies, Bee ............... 96 Virgins' Bower (see Clematis).

IOI Sweet Alyssum (see Alyssum).. 62 Virginian Stock (see Malcomia).

So WAHLENBERGIA.............. 78

o Waitzia .............

Wake Robin (see Trillium).

65 Wallflower (see Cheiranthus).

43 Washing-Machine, Clothes ..... Iog

Water-Barrel Truck .......... Io9

Water Lily .................. xxi

I 2 Water-Pots .............. Ios

Wax, Grafting .............. 54

46 VVeeders, Hand ............. I12

Veeder Wiards ............. I00

IVeigelia ................. gI

47 Weights, Table of........... 60

Whale-Oil Soap............. 54

45 Theat .................. 40, 55

60 Wheelbarrows ............. I09

Io6 Wheel Hoes............. 102, 103

82 White Fringe (see Chionanthus).

75 Whitlavia................. 78

43 Wigandia ........................ $\delta_{4}$

40 Wild Indigo (see Amorpha).

40 IVillow (Salix) ............. 93

Wind Flower (see Anemone).

II2 WVire, Bouquet .............. 54

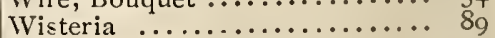

IVood Meadow Grass.......... 43

XANTHOCERAS . .......... $9^{1}$

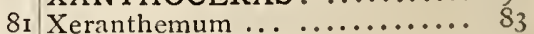

4 I YANKEE PLOW............ 98

54 Yarrow (see Achillea).

38 Yellow Oat Grass ............ 43

54 Yucca Filamentosa... ........ 9o

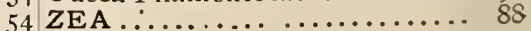

54 Zinc Labels................. 54

54 Zinnia.......................... $59,84,8$ s 

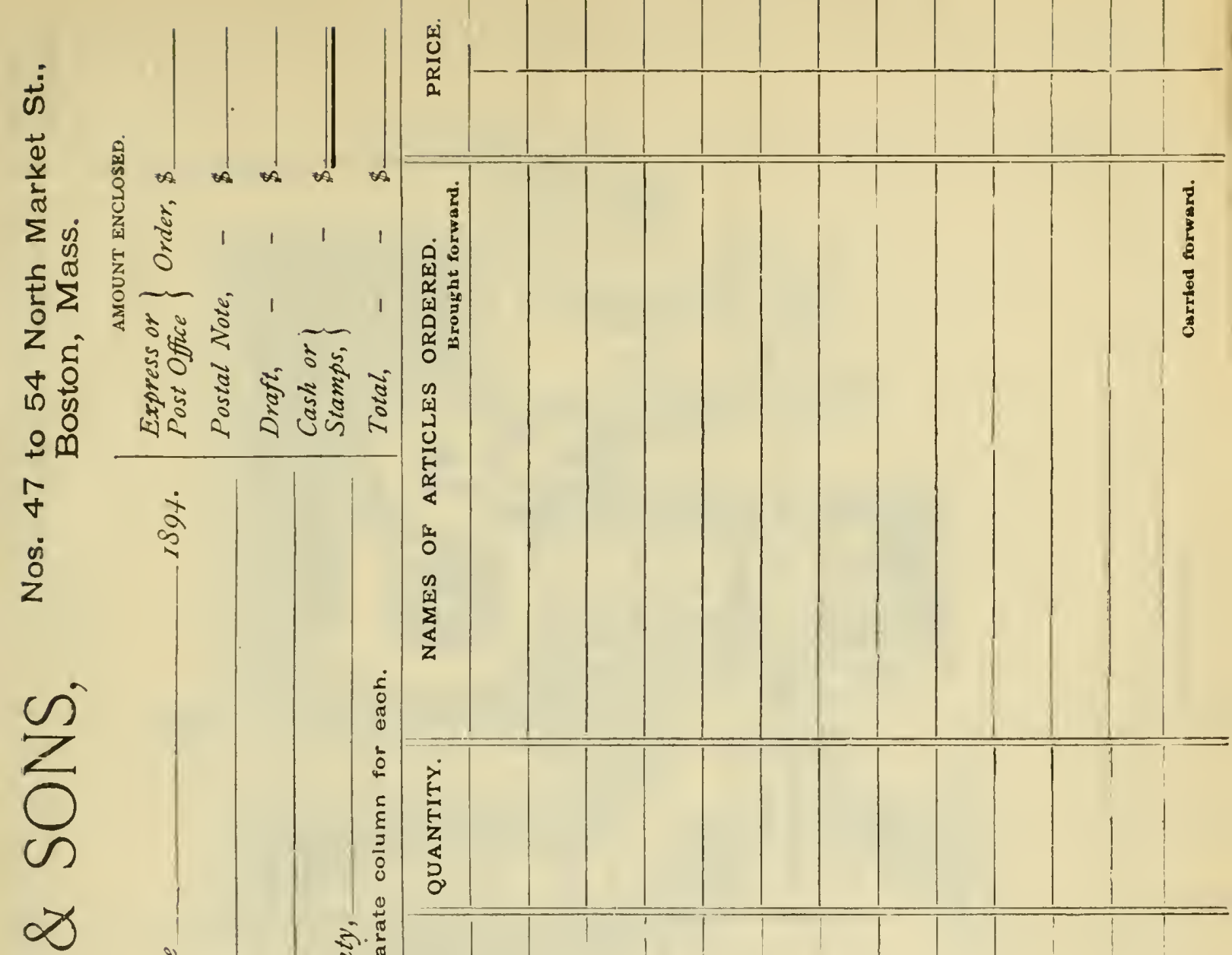

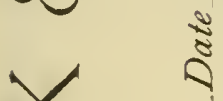

$U$

ㄱ.

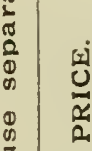

$\frac{\omega}{\infty} \frac{}{\infty}$

$\frac{a}{0}$

मै

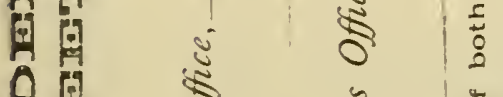

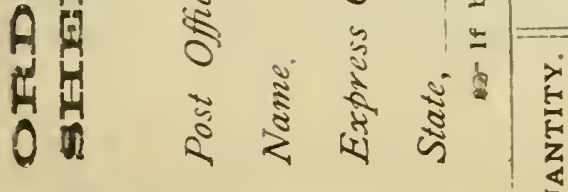



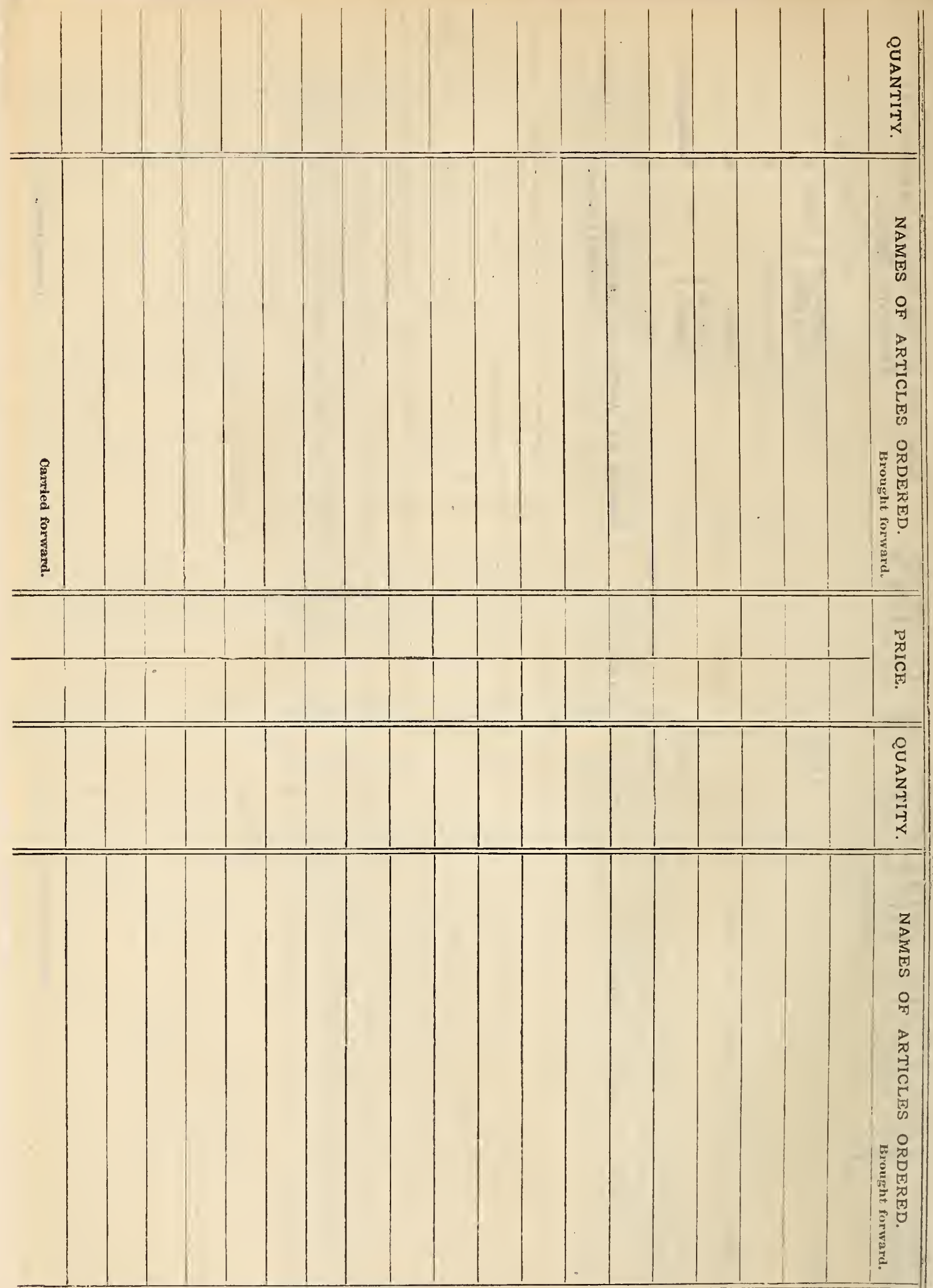

Sper. 


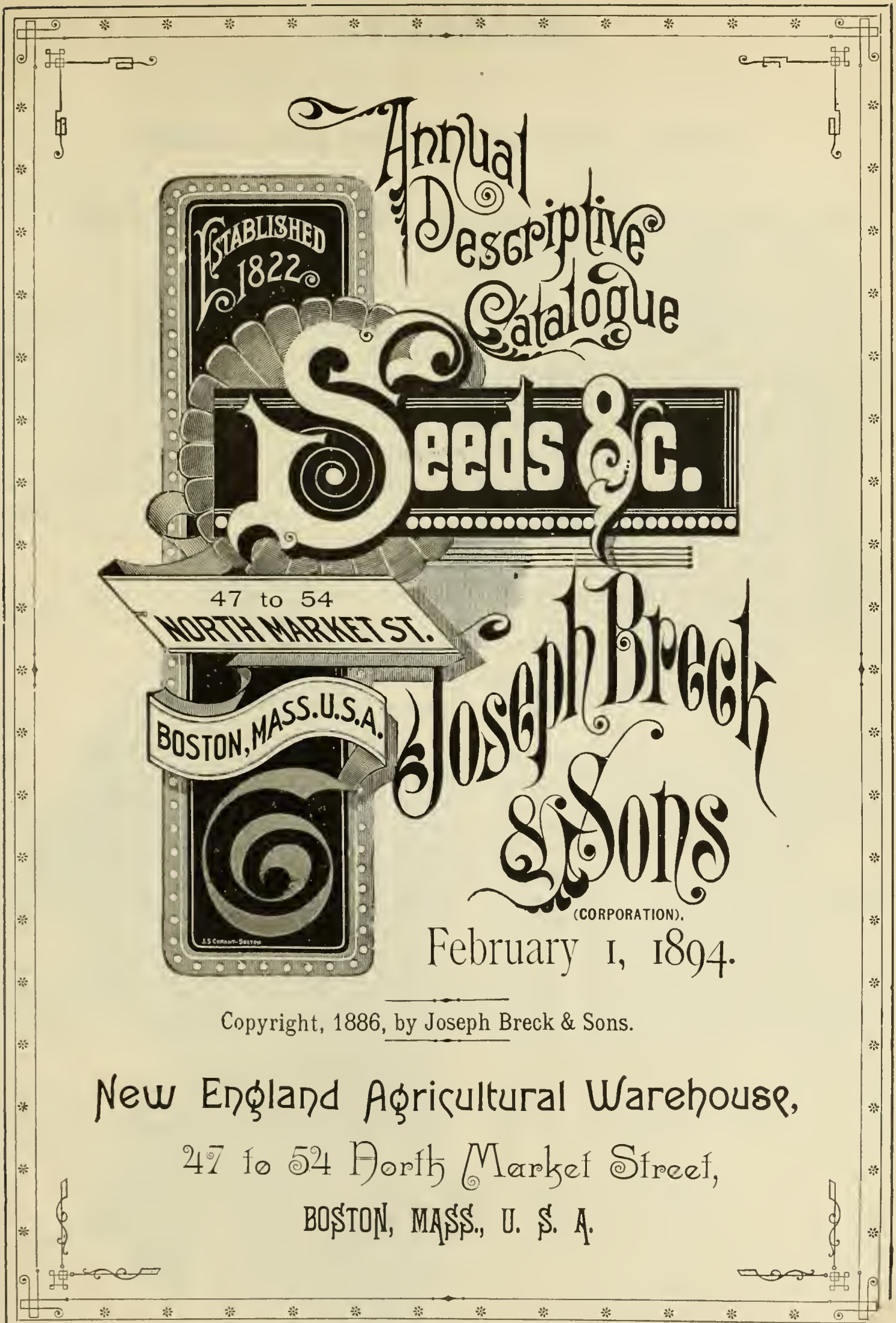




\section{OUR SPEOIALTIES ARE}

\section{Everything for Farm, Garden and Lawn.}

Our stores are by far the largest in New England, our knowledge of producers and facilities for obtaining the very best of everything in our line are unsurpassed. The care exercised in selecting and testing every article before sending out, coupled with our moderate prices, prompt service and special delivery offers are some of the factors that have made our seeds, bulbs, plants, tools, etc., popular alike with the amateur and professional gardeners and farmers of the United States. Quality being always our first consideration, purchasers when placing orders with us may feel assured of receiving only goods of the highest standard of excellence.

BACS.-Persons remitting with their orders are respectfully requested to include a sufficient sum to coves cost of bags necessary to contain purchase. The prices for sound cotton bags are : 2 bushels, $20 \mathrm{cts}$; I bushel, 20 cts.; $1 / 2$ bushel, I 5 cts.; $1 / 4$ bushel, Io cts.; $\frac{1}{8}$ bushel, 8 cts. The amount charged will be refunded if bags are returned in good condition free of expense to us, within one month from date of purchase.

NAME AND ADDRESS.- Always be careful when ordering goods to give name in full, postoffice address and name of freight depot or express office to which goods are to be forwarded. Delay in receiving goods is frequently caused through purchaser's failure to give these particulars.

\section{OUR GUARANTY.}

First.-Our seeds are guaranteed pure and clean, and of the percentage of vitality named on the label accom. panying and describing contents of each package.

Second.-This guaranty is subject to the test and analysis of the Botanist of any of the State experiment stations, and to properly authenticated complaint being made to us within twenty days from time of purchase of seeds complained of. If the result of the analysis does not confirm the guaranty, we will take back the seeds, and refund the money paid for them, and pay the cost of transportation both ways.

Third.-Seeds once sown, or the above specified time for complaint having expired, our responsibility ceases. The results in field culture depend upon so many things besides the quality of the seeds, that the growth and crop cannot be guaranteed.

The advantages of this method of guaranty will at once be apparent to the careful farmer; it will give security as to vitality, freedom from noxious weeds, and to some extent, confidence as to varieties planted; in short, by obtaining seeds a few days before they are required for planting, you can have, without cost (for we assume expenses if results of tests are unsatisfactory), a warrant against everything except the visitations of Providence.

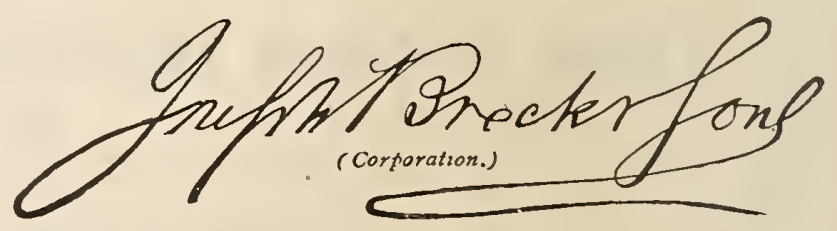




\section{4.}

\section{VEGETABLE SPECIALTIES.}

Under this heading we include new varieties that are, we believe, meritorious and standard sorts worthy of special mention.

\section{THORBURN EXTRA-EARLY MARKET BEAN.}

This bean las been grown to some extent in Germany, but never was catalogued or generally known there. An American, interested in horticulture, noticed it two years ago, and was so impressed with its merits that he brought some home with him. It seemed to him to possess, in a marked degree, the qualities most desired by our market gardeners here.

It is an exceedingly vigorous and healthy grower, and enormously productive, the pods being borne in thick clusters, and as many as 35 to 40 on each plant. In earliness of ripening it is some days ahead of the Mohawk, and fully a week before the Best of All. It is rust-proof to a remarkable degree. Out of a lot left in an open vessel for eight days, not one was found to be yellow or rusty. The seeds being black, .6 is likely to remain true to its character longer


than light or different colored beans. The pods are of a light-green color, long and perfectly round, solid-fleshed, and of very soft marrow and texture. For earliness, productiveness, solidity of flesh, and roundness of pod, it excels any now in cultivation.

The stock is limited, consequently is oflered in packets only, this season. Per packet, 10 cents.

\section{EARLY BLACK LIMA POLE BEAN.}

A black-mottled seeded variety of the Sieva or Sewee Pole Bean. The seeds, which are about half the size of the large Lima, do not rot in the ground so readily as the latter. The vine is a mediumvigorous grower, quite hardy, and enormously productive; the clusters being borne in such profusion upon the poles that they presedt the appearance of veritable ropes of pods. from the ground up to a height of six or seren feet. The pods have a uniform length of about three and a half inches, and contain three and four beanseach. A given measure will shell out over a third more than the ordinary Lima. They are of a dark-green color when cooked, and in their extreme tenderness, delicate quality, and delicious flaror, they stand without a peer. We venture to say that any one once raising them for his own table will every planting season thereafter reserve space for the "Black Lima."

Packet, 25 cents; pint, 75 cents; quart, \$1.25

Gexts : Your annual was duly received. I have purchased seeds of the old firm and its predecessors, and have always found the seeds satisfactory. Enclosed find remittance, etc.

D. H. S., Oconomozvoc, Wis.

See Special Offers on third page of cover. 


\section{THE WARREN BUSH BEAN.}

A green podded variety of extra quality. It may be used either as a string or shell bean, and will compare most favorably with the best wax sorts for the former purpose, and with the pole cranberry for either. The pods are succulent and tender; and these qualities are retained to a very advanced stage of growth, or until quite of suitable size for shelling. Per packet, Io cents; quart, 30 cents; peck, \$I.5O.

\section{BURPEE'S BUSH LIMA BEAN.}

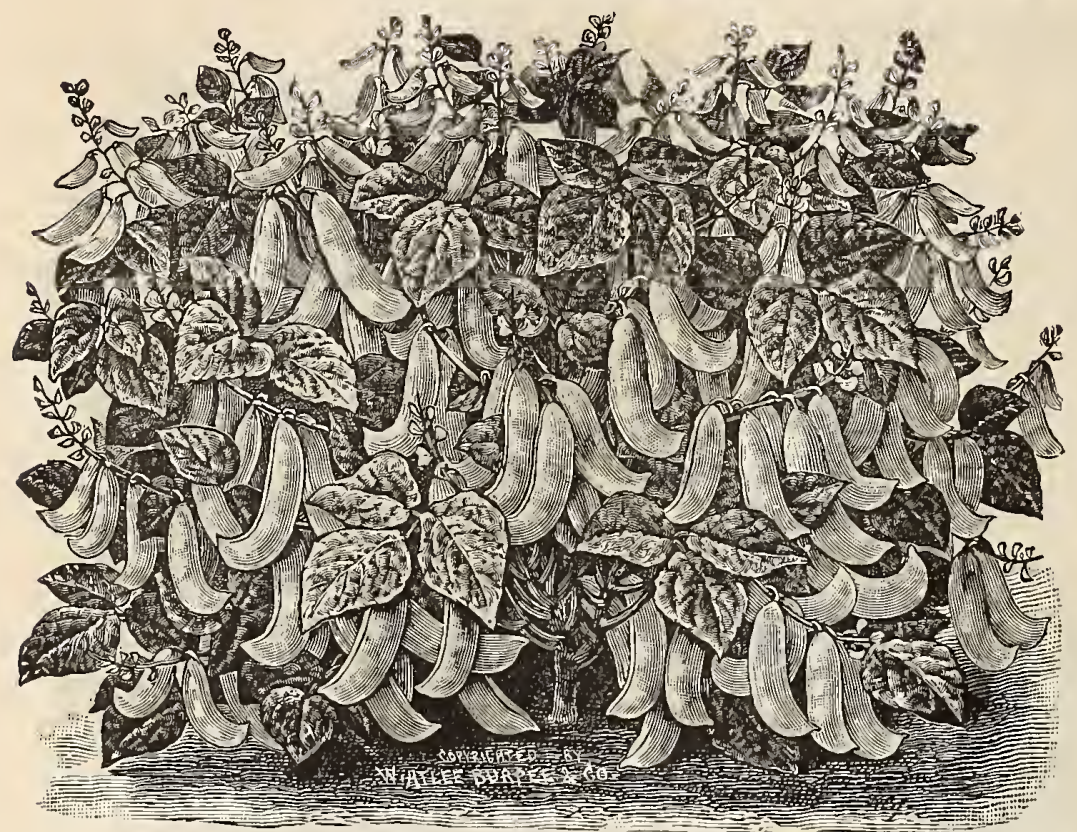

BURPEe's Bush Lima comes absolutely true from seed. The bushes grow eighteen to twenty inches high, and each develops into a magnificent circular plant from two feet to three feet in diameter. The bush character is thoroughly established, not one plant in a thousand showing any disposition to "run." The thickness of the main stalk and branches of the plant indicate the strong constitution of this variety. It is an immense yielder, each bush bearing from 50 to 200 of the handsome large pods, well filled with very large beans, which are identical in size and luscious flavor to the wellknown large pole Limas. By the introduction of this most valuable novelty, the largest and best Lima Beans can now be raised in quantity at small cost, without the expense and labor attached to the use of poles.

Per packet, $I_{5}$ cents; pint, 40 cents; quart, 75 cents ; peck, $\$ 5.00$.

\section{DREER'S BUSH LIMA BEAN.}

This is a true bush variety of the Dreer's Improved Lima, possessing all the good qualities of that excellent and well-known sort. The plants grow from $1 \frac{1}{2}$ to 2 feet high, of vigorous bushy habit, producing pods in great abundance. The beans grow close together in the pods, are very thick, sweet, and succulent, and ripen fully ten days earlier than the pole Lima. A proof of its productiveness is the fact that many growers have raised specimens bearing from one hundred to one hundred and eighty-five pods.

Per packet, 15 cents; pint, 40 cents; quart, 75 cents; peck, $\$ 5.00$.

\section{SOYA BEAN (Glycine Hispida).}

\section{The price on Soya Beans is net at our store.}

The kindly reception this bean received last season, and the reports we have since had from many persons who planted it, lead us to believe that it will be in large demand this spring. It was introduced from Japan a few years ago, and put in commerce by us, spring of $I 893$. It is a mediumearly white that will not only produce an immense quantity of valuable fodder and ensilage in New England, but from which may be harvested a thoroughly matured crop of beans averaging from twenty-five to thirty bushels to the acre. These beans can readily be ground by local millers, and the meal is more valuable ton for ton than cotton-seed meal, bran, or any grain. This crop affords the Northern farmer a means of producing the nitrogenous foods which every feeder knows are essential to economical feeding and the largest products either in growth or milk, and as the plant gather's its nitrogen from the atmosphere, it should enable the farmer to dispense in a large ineasure with purchased nitrogenous fertilizers. The superiority of this bean over clover for fertilizing purposes has already been clearly demonstrated, and it is only a matter of time when it will be generally recognized. It has a stiff stalk, growing three to four feet high, holding the pods well off the ground, and it matures all the beans together. When roasted and ground the beans form an excellent substitute for coffee. They may be sown broadcast at the rate of half a bushel per acre, or

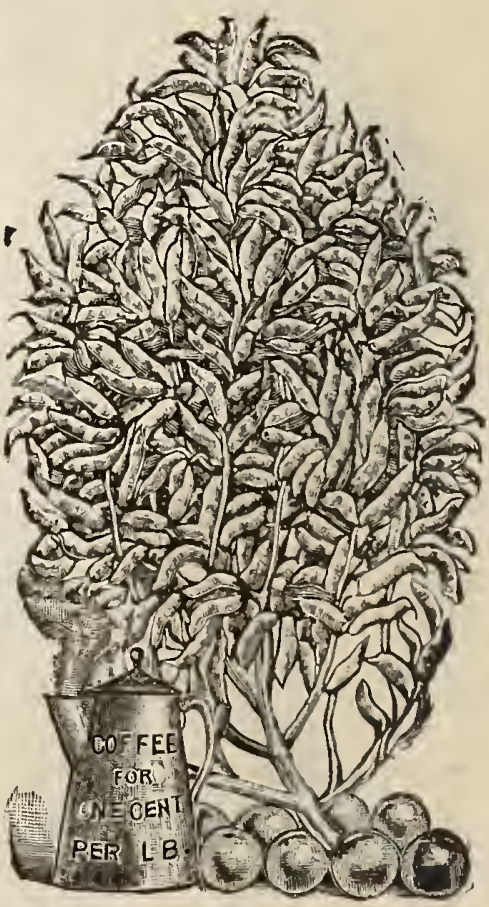
planted in drills three feet apart and one foot between the plants.

Per packet, Io cents; quart, 25 cents; peck, \$I.50.

| I found your seeds last year very SATISfactory. T. A. B. J., Turner's Falls, Mass. | See Special Offers on third page of cover. 


\section{COLUMBIA BEET.}

The originator says: The handsome appearance of this distinct new Beet is well represented in the illustration herewith. The roots are of a neat turnip shape, with smooth skin and deep blood-red fesh, of rich tender quality. It is ready to use very carly, growing as quickly as does the Eryptian, while it does not become coarse and stringy as does that variety when ot large size. Compared with such famous sorts as Edmands' and Eclipse, the Colunbia has proved earlier than either, and even better in quality than these two really first-class varieties. In habit of growth it is remarkubly thoroughbred, the foliage being small, neat, and of a rich bronze color. We have received many voluntary letters from our custom. ers, all of whom have been most enthusiastic in praise of Tine Columbia BeET, both as an early and main-crop variety. We are sure that market gardeners will find it a splendid variety, whilc its fine flavor as a table beet will clelight all private planters. $\$ 1.50$.

Per packet, 10 cents ; ounce, 15 cents; pound,

\section{CROSBY'S EGYPTIAN BEET.}

A desirable extra-early market variet $y$, selected froin the original Egyptian by the late Josiah, Crosby, of Arlington, who spared neither labor nor expense in perfecting it. It is as early as the original variety, thicker, of better color and quality, besides being smoother. The seed we offer is not Arlington grown, but was carefully raised from stock seed supplied by an Arlington farmer.

Per packet, 5 cents. ; ounce, ro cents; pound, \$I.00.

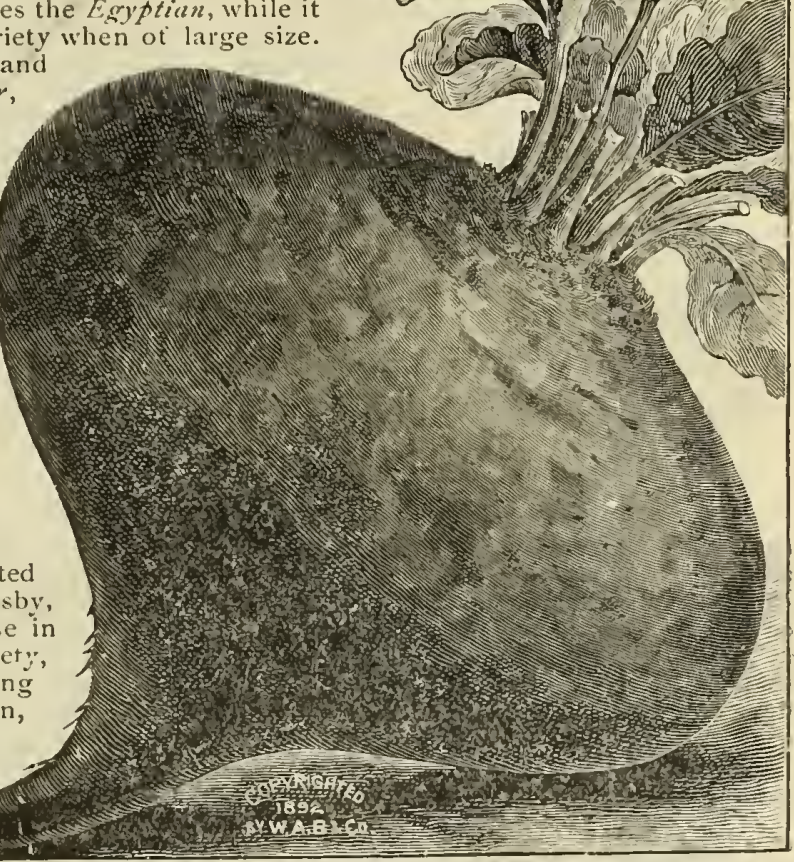

NEW ROSE CELERY.

There is, we know, a general dislike to all Celery that has any red shade of color. but as quality is and should be the first consideration, we have confidence in recommending this sort to the special attention of our customers. The color is, as the name implies, a delicate shade of rose, the quality (and comparisons have been made by disinterested authorities) is ahead of any other variety in cultivation, being fine, inild-flavored, solid, crisp, and entirely free from stringiness.

Per packet, 5 cents; ouncc, 25 cents; pound, $\$ 3.50$.

\section{GOLDEN SELF-BLANCHING CELERY.}

Not a new variet $v$, but one that is much in demand among Narket Growers. It is a "sport," and like most sports has not a perfectly fixed character, and is liable to show in the best obtainable strains plants of the original variety from which it sprung. The Seed we offer is direct fiom the originator and introducer, who claims that he has now perfected the strain, and says that it can be offered with confidence, as it will undoubtedly prove almost entirely true to character and give satisfaction to customers. The plant has a beautiful ap-

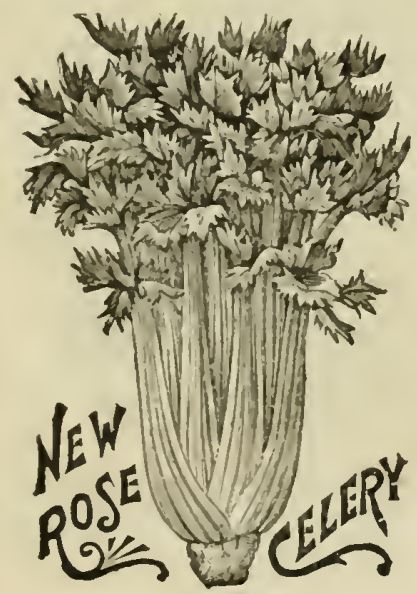
pearance, its compact habit of growth and straight. vigorous stalks being very noticeable. The ribs are perfectly solid, crisp, brittle, and of delicious flavor, surpassed by no other variety, whilc it has the merit of being selfblanching to a very remarkable degree; without earthing up or other covering, even the outer ribs become of a handsone yellowish-white color. The heart is large, solid, and of a rich golden color. Its keeping qualities are wonderful.

Per packet, to cents; ounce, 35 cents; $1 / 4$ pound, $\$ 1.00$.

\section{GIANT PASCAL CELERY.}

This, the best keeping, best flavored, and heaviest cropper, is a sport from the Golden Self-Blanching Celery; it couples with all the meritorious features of that variety greater size and better keeping qualities. The stalks are very largc, thick, solid, crisp, and of a rich nutty flavor, entirely free from any trace of bitterness.

Per packet, 10 cents; ounce, 35 cents; $1 / 4$ pound, $\$ 1.00$.

I received rour catalogue.

I will, in due time, send you h order for Seeds, as 1 had good success with those I obtained from your house the past seasolt.

W. P. McC., 2uinsigamond, Mass.

See Special Offers on third page of cover. 
PERFECTION RED CABBAGE.

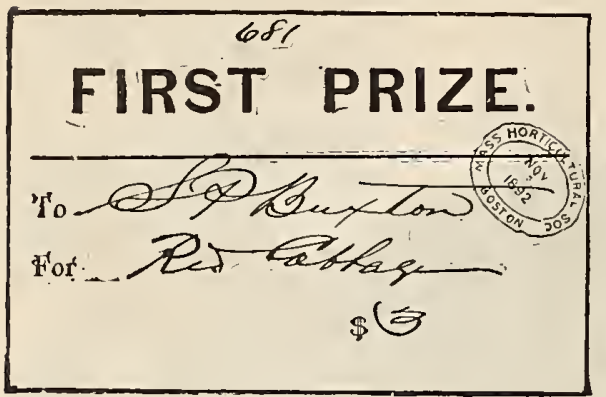

We have pleasure in again offering seed of this valuable red cabbage grown by the originator, Mr. Buxton, of Peabody. This is beyond question the best "Red" brought to Boston market, and is unsurpassed by anyin color, size, dwarf compact growth, certainty of heading and solidity. It is the result of years of careful and skilled selection for these desirable points, and is nearer to what its name implies - PERFECTION - th a n an $y$ other Red Cabbage. We could print many testimonials from successful market and private growers regarding its excellence, but it is too well known and popular to require them. First prizes have always been awarded it at the Massachusetts Horticultural So-

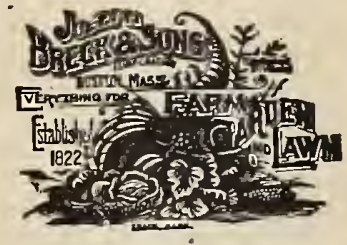

ciety's shows and elsewhere when exhibited. The genuine is for sale only in packages sealed with our trademark. Per package, Io cents; ounce, 40 cents; pound, $\$ 4.00$.

\section{BRECK'S WHITE BOUQUET CAULIFLOWER.}

Since we introduced Breck's White Bouquet Cauliflower three years ago, it has, on its merits, found its way into nearly all the best private and market gardens in New England, as well as many other States. We claimed it to be in all respects equal at least to any other sort in cultivation. Now a great many of our customers, who have grown it, claim it is better than all other sorts, no matter at. what price offered. We have continually aimed to improve the strain, if possible, by

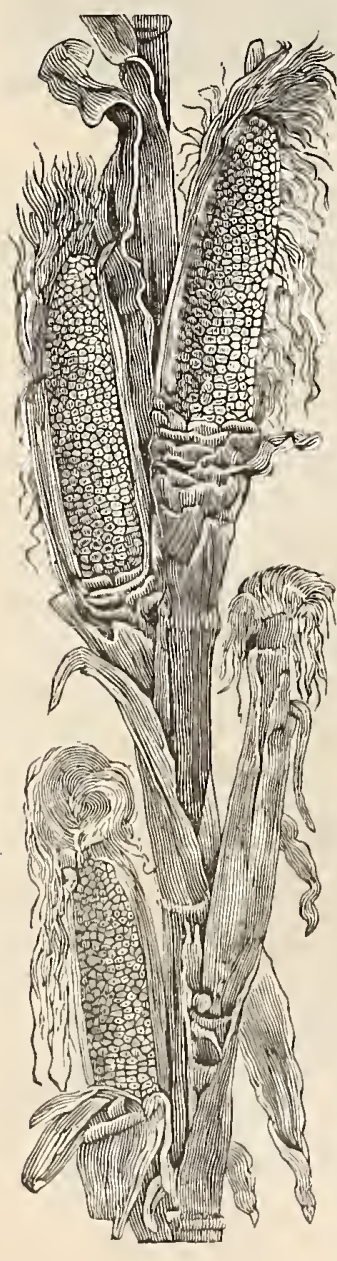
selection, and we feel we have succeeded in producing a type that is without an equal, either for forcing or open-ground cultivation. It is earlier than any other cauliflower, produces a larger percentage of solid pure-white heads, averaging ten inches in diameter, is dwarfer and more compact in habit, and has no useless, rank-growing outer leaves to take up space. Its natural early maturing, coupled with its neat form of growth. make it peculiarly suitable for growing under glass during winter or spring. WVe own the entire seed stock, and every package of the genuine will be sealed with our trade-mark. Per packet, 25 cents; ourice, $\$ 3.50 ; 1 / 4$ pound, $\$$ I 2.00 .

We had two acres of Breck's White Bouquet Cauliflower last season. It proved more satisfactory and profitable than any other variety we ever grew. W. G., Woburn, Mass.

\section{SILVER COIN SWEET CORN.}

The originator says: We take pleasure in introducing this grand new sweet corn. The stalks usually each produce two and occasionally three very large ears. It is remarkable, however, that, although of such large size, it is fully as early as Stowell's Evergreen. It is also more prolific and the ears more uniformly well filled at the ends. The kernels are broad and deep, and of pearly whiteness in all stages of growth. The depth of kernel is aptly referred to by one admirer, who says that "those who like to eat corn without gnawing a cob will hail the new Silver Coin with delight." In fact, considering the tender and luscious quality of this grand new Corn, together with its depth of kernel, it is really a luxury to secure it after eating ordinary kinds. It will be found to excel in two very important points, - productiveness and quality. Per packet, I5 cents; quart, 35 cents; peck, $\$ 2.25$.

\section{COUNTRY GENTLEMAN SWEET CORN.}

Ne-plus Ultra, from which this is a selection, is well known as the most tender and sugary sweet corn grown; the only objection ever raised against it was its small size. A skilled corn-grower in Connecticut undertook the task of overcoming this fault, and has now secured a strain that retains all the good qualities of the original, but with much larger ears and kernels. The Country Gentleman is a vigorous grower, almost equal to Stowell's Evergreen - and bears an average of three ears to the stalk. The kernels are pearly white, long, thin, and exceedingly sweet. We recommend it to all as a valuable main-crop variety. Per packet, Io cents; quart, 25 cents; peck, $\$ 1.25$; ears, 5 cents each.

Seeds you sent last spring proved to be in all respects satisfactory, and the extras, well - most desirable.

H. A. G., Salem, Mass.

See Special Offers on third page of cover. 


\section{CRIMSON, GERMAN, OR SCARLET CLOVER.}

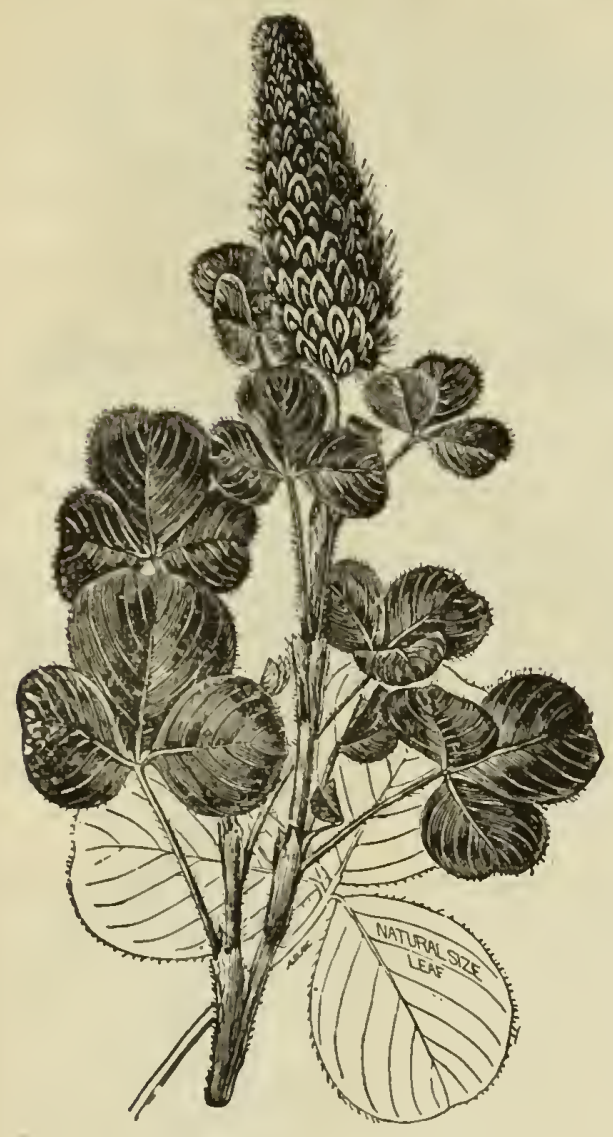

Owing to articles in the agricultural papers a large inquiry was made last year for this clover. It was first introduced from Italy into our Southern States, and has gradually found its way north. It is recommended as being a valuable green manure crop, and for an April green-food crop for cattle, or it can be made into hay during May. Sow broadcast during July or August at the rate of fifteen to twenty pounds peracre; it may be sown among corn at the last hoeing, and it will make a good "catch" on stubble land by merely harrowing the soil with a heavy spading or disk harrow.

Per pound, 20 cents ; IOO pounds, \$15.00.

"PEARL" WHITE EGG PLANT.

A delicious vegetable, and one of the handsomest and best novel ties ever sold. It originated in Georgia.

The plant is a large, vigorous grower, and comparatively free from

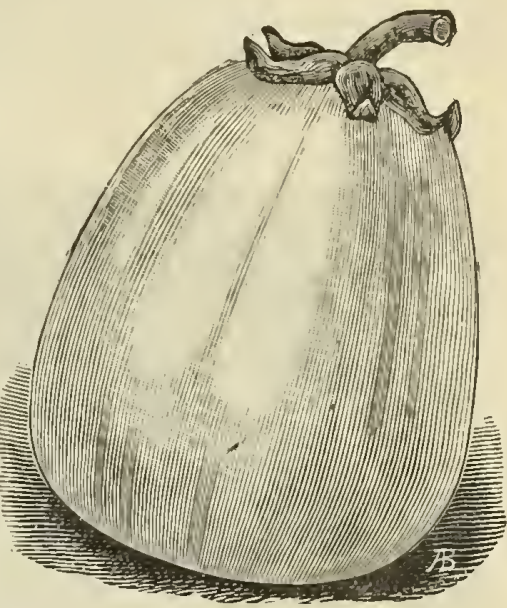
thorns. The fruit is pure creamy white, with slight shading of a very light green near the stem, thus being of much more attractive appearance than the purple sorts; beautiful in shape, resembling somewhat the purple variety, as large and larger in size, and more prolific. In eating quality it is superior, being more delicate, very fine grain and well-flavored. It makes one of the most palatable dishes, either baked or fried. There is not a garden in the land which would not be improved by this vegetable being represented in its collection. Per packet, 10 cents.

I make principally the same selection as formerly, as everything proved so satisfactory, especially so the Peas and Onions.

They were really superb. $\quad$ S. B., Rockland, Me.

\section{EVERGREEN CUCUMBER.}

The originator of this variety says he distributed spring of I Sgo ten thousand packets of it, and all reports were "praising it in unstinted terms." This variety has been thoroughly tested the country over, last season,

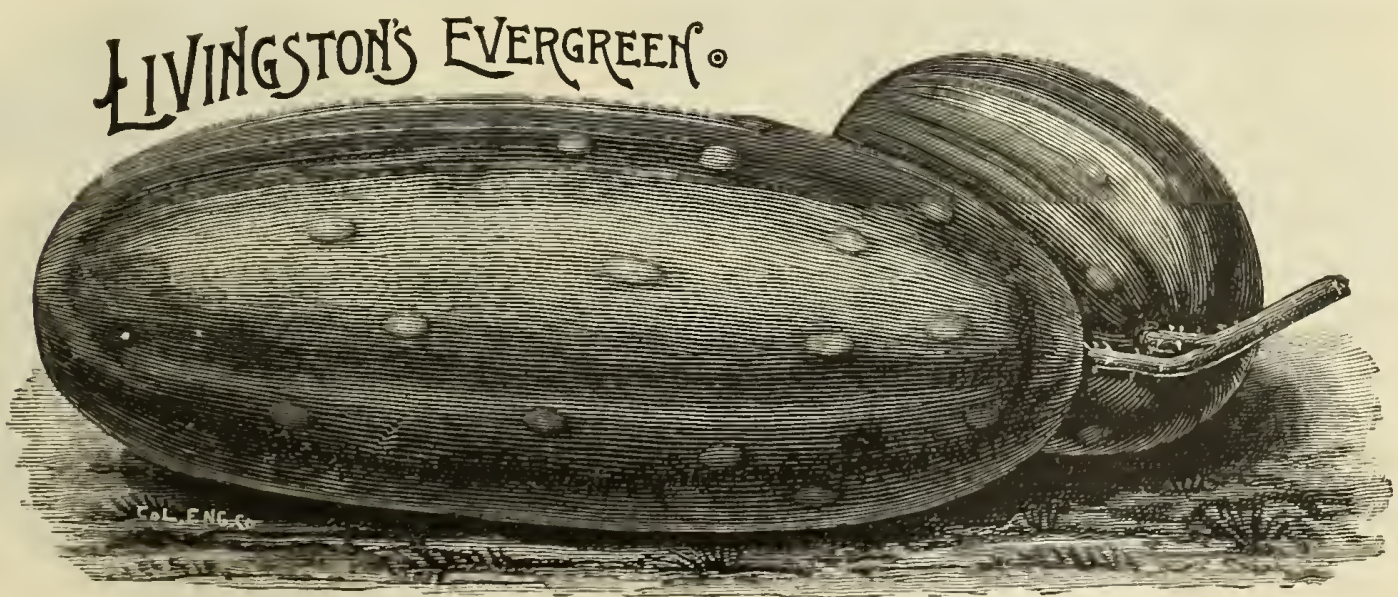

and the farorable reports are still coming. One of our special claims for this variety is its wonderful prolificacy. The grower to whom we intrusted the contract for growing our supply of the seed, states, after the frost had killed the vines, it really looked as if the fruit entirely covered the ground when the field was viewed from a short distance. A nother grower says it outyields average sorts four to one.

Per packet, Io cents; ounce, I5 cents; pound, $\$ 1.25$.

See Special Offers on third page of cover. 


\section{ARLINGTON BLACK-SEEDED TENNIS BALL LETTUCE.}

The seed we offer under this name is a selection of the deservedly popular Black-Seeded Tennis Ball, grown by $M r$. C. A. Learned, Arlington, and highly prized by the market gardeners of that and neighboring towns who make a specialty of vegetable-growing for the Boston market. It is adapted for forcing as well as out-door cultivation, and has been selected with such care for a number of years that Mr. Learned now says " ninety-nine per cent. of it will head good and hard under ordinary conditions." It makes but few outer leaves, and for this reason can be planted quite closely, - say six to seven inches, - which is a great consideration when grown under glass. Packet, 10 cents; ounce, 30 cents; pound, $\$ 3.00$.

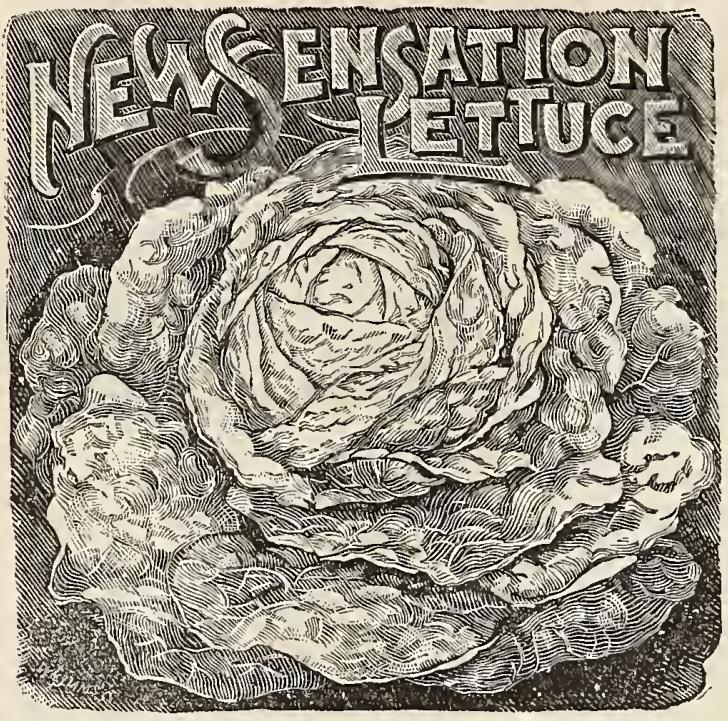

\section{SENSATION LETTUCE.}

This variety was generally catalogued last season, and was received with favor by shrewd market gardener's and private growers, many of whom agree in pronouncing it the best lettuce they have ever grown for forcing, and equally valuable for growing in open ground during the hottest summer months. It is a beautiful light yellowish-green color, leaves much blistered on the surface, and of very superior even quality. It has the peculiarity of forming a solid head, even before half grown. It is the shyest seeder of any lettuce we have ever seen. Per packet, Io cents; ounce, 30 cents; pound, $\$ 3.00$.

\section{NEW BOSTON MARKET LETTUCE.} (ALSO KNOWN AS "BIG BOSTON.")

This new variety is a distinct strain of the popular Boston Market Lettuce, and is identical to it in all respects except size and time of maturing. It is very desirable for both open ground and forcing, and although perhaps a week later than the common sort, its immense solid heads will commend it to the market grower, while its excellent quality is sure to make it a favorite in the home garden. Per packet, Io cents; ounce, 30 cents; one-fourth pound, \$1.00.

\section{IMPROVED EMERALD GEM MUSKMELON.}

The Emerald Gem Muskmelon has for some years been very popular on the Boston market, the best hotels and restaurants preferring it to all others, even at a higher price. Growers, however, while realizing that a good market was always obtainable for the Emerald Gem on account of its delicious flavor and thick, sugary flesh, usually preferred to plant a larger-growing sort, even though it did not meet with such ready sale. They can now have in Breck's Improved Emerald Gem a variety that couples size with all the desirable qualities of the original. It nas the same thin, dark-green rind, thick, melting salmon-colored flesh, and high flavor. We recommend all our customers to give it a trial, especially those who like the Emerald Gem type and quality. Our supply of seed is again quite limited through the great care taken in selection; we therefore offer it in sealed packets and ounces only. Per packet, Io cents; ounce, 50 cents.

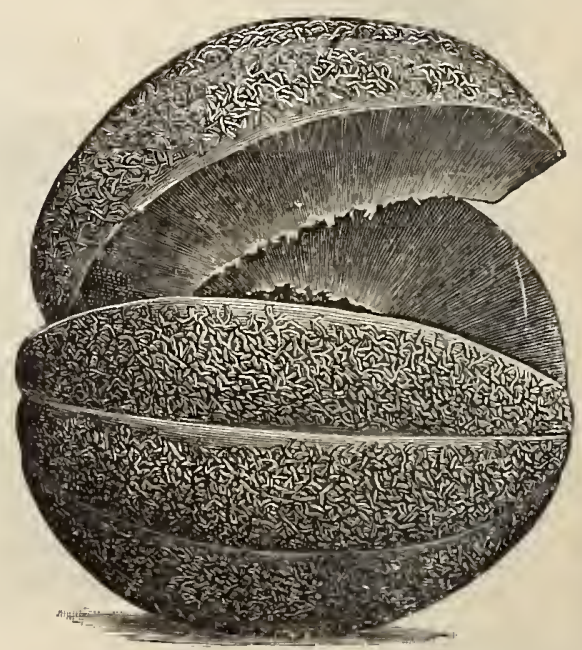

Seed received all right. It is the handsomest lot of seed I ever had the pleasure of seeing. The same has also been said by a number of amateur Gardeners here.

F. E. W., Riverpoint, R.I.

See Special Offers on third page of cover. 


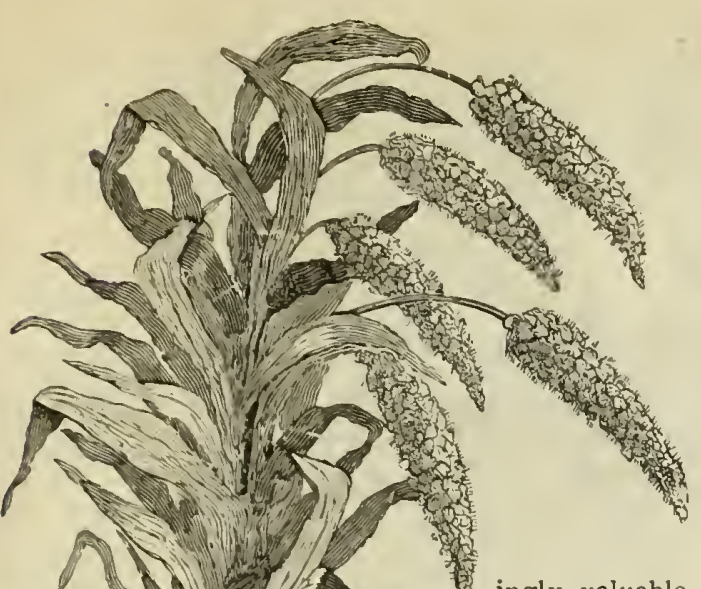

\section{JAPANESE MILLET.}

(Panicum Miliacenm.)

This wonderful millet proved in the hands of hundreds who tried it season of 1893 to be more meritorious than our greatest claims for it set forth. The limited stock of seed at our disposal was quickly sold, and many of our customers who planted small lots for trial have since written us praising it very highly, and ordered a supply of seed for this year's sowing. The original seed-stock was imported three years ago from Japan, where the grain is largely used as human food. The importer in 1891 planted a small plot of ground, which yielded at the rate of six and three-quarters tons dry straw, and over ninety bushels of seed per acre. The yield of seed is surely a remarkable one, especially since a considerable amount was lost through the ravages of birds (which prefer it to comunon millet) as well as by rattling out, for unlike common millet, this threshes very easily. There is good reason to believe this new variety will prove an exceedingly valuable crop for green fodder or for the silo, as it is as much superior in every respect to all other millets as is the Japanese buckwheat, that has since its introduction gained such popularity over the common sort fornerly largely grown. The seed of this millet constitutes an excellent grain for hens, and when ground is a wholesome, nutritious, and economical food for cattle. The plants attain an average height of six feet, are short-jointed, and at every joint there is put forth an immense number of long, thick, fleshy leaves that increase its value as a cattle food. The heads average a foot in length and over six inches in diameter. Our illustration, drawn from nature, is one-twelfth natural size, but it scarcely conveys an adequate idea of the great food-producing qualities of this millet. The demand for this millet we believe will again exceed the supply; therefore we recominend our patrons who desire to secure seed to order at once. The price we quote is very low in order to induce a general demand for this variety, and is not subject to either of our special offers. Per peck, 60 cents; bushel, \$2.0o.

\section{MAMMOTH SILVER KING ONION.}

This is one of the largest onions in cultivation, averaging from 15 to 22 inches in circumference, and often weighing from $2 \frac{1}{2}$ to 4 pounds each. It is quite early, of fine shape, a little flattened, but very thick. The skin is a beautiful silvery-white color; the flesh pure white, tender, and very mild-flavored. It has attracted much attention by its large size and handsome appearance, which qualities, together with its mild flavor, recommend it for the exhibition as well as the home table. Per pkt., Io cents; ounce, 25 cents; pound, $\$ 2.50$.

\section{POTATOES.}

The seed potatoes we offer are grown under contract in Northern Maine, and are usually harvested sufticiently early to allow of delivery being made to purchasers before severe frosts begin to fall; we will, therefore, when desired by intending planters of 1895 or our South-

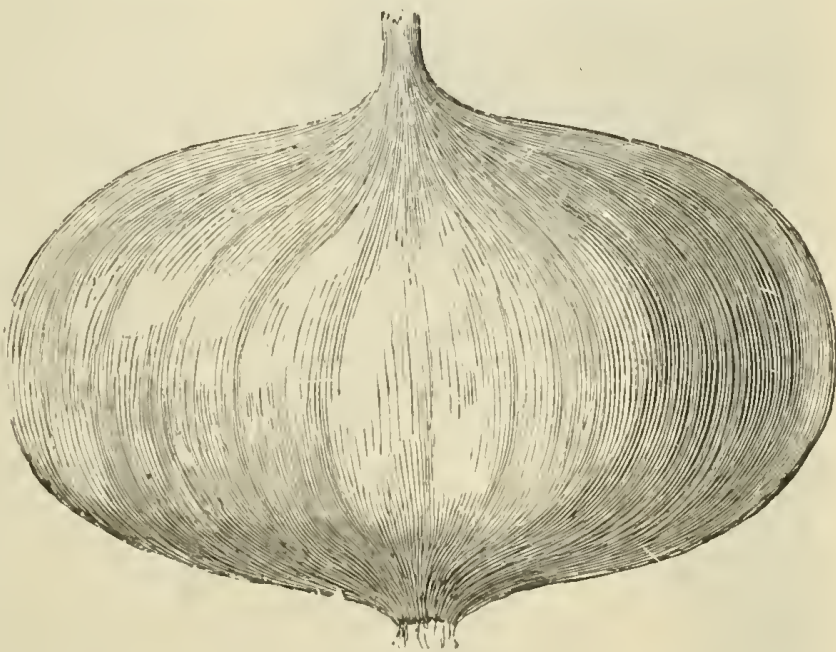

ern customers, make shipments during the autumn of this vear. This method will enable us to sell at a lower price than if we had to store the potatoes all winter, and be of value to the planter, in that it assures safer transportation and affords opportunity to have the tubers cut and, if wished, sprouted, ready to plant as soon as the soil can be got into condition to receive them.

For descriptive list of varieties see page 36 . We invite correspondence on the subject, and will quote prices on application after September 1 .

I am glad to say that all the seeds sent ine by Messrs. Breck S Sons have done well.

$$
\text { n }
$$
never do as well here as at home, though their seed is bearing better than any English seed I nave ever seen. The Wax Beans are a sight to gladden any horticulturist's eyes. 'The root vegetables are all doing well, though the beet seems to lose somewhat in flavor. Rev. J. P., Meiktela, Upper Burmah.

See Special Otfers on third page of cover. 


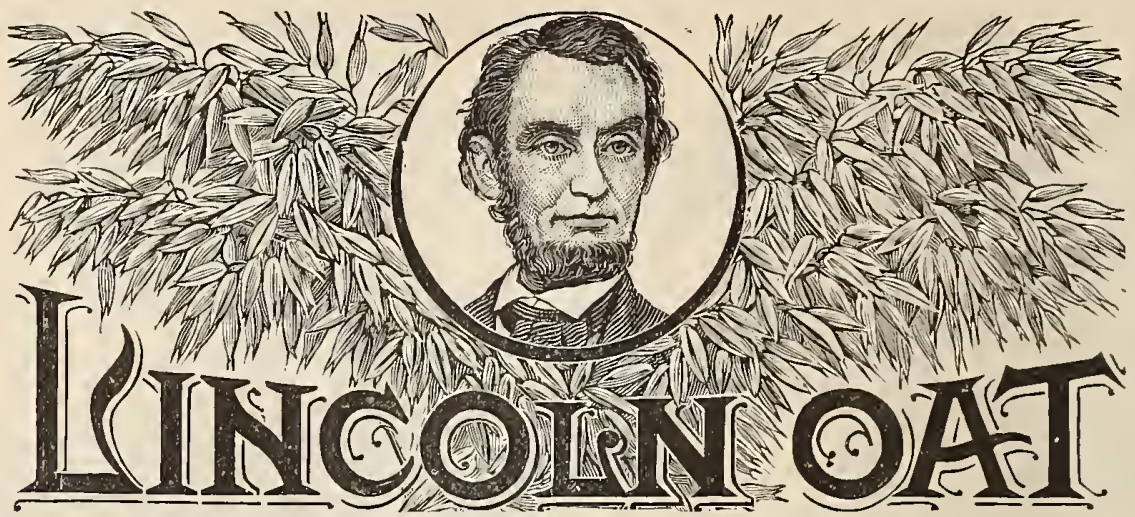

The continued hot, dry weather in New England during the growing season of I 893 prevented this oa! from producing the immense crops it has proved itself capable of in the Northwest, where the variety originated a few years ago. We have, however, lost none of our faith in it, because we know that in seasons favorable to the growth of this valuable grain it will show better results than any other kind in quantity and quality of grain, as well as straw.

The Lincoln Oat is again offered with the belief that it will prove the most popular of any oat yet introduced. It has produced one-third more than any other variety grown in the same localities, is very early, entirely rust-proof, stands upp perfectly, even on heavy soil, and is best for feeding because of its thin hull, heavy meat, and soft nib.

Every enterprising farmer should sow at least a bushel in order to procure seed for next season. Unlike most new oats, the LINCoLN is offered at a price so reasonable as to place it within the reach of all. $\$$ I.oo per bush., net. Not subject to special offers.

\section{PARAGON PEA.}

For many years market and private growers have been seeking for a main crop pea that produces an abundance of even-sized, good-colored pods well filled with first-quality peas. All these qualities, we believe, they will find combined in the Paragon. To be sure the seed is light-col-

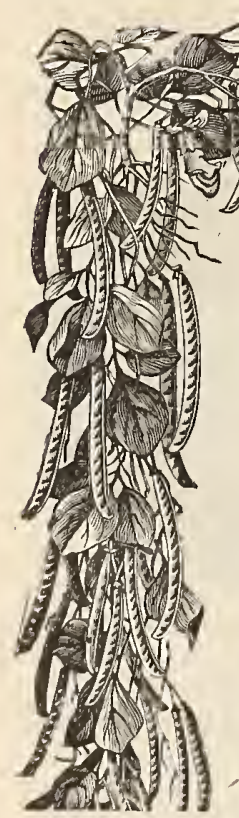
ored, and the vines grow all of three feet high, but the quality more than offsets the color, and quantity cannot be had without a vigorous, healthy vine. The originator describes this new variety as follows:

"Height, three feet; double podded; medium late; long, straight pods; six to nine peas. Stubbed, stocky vine with luxuriant foliage; pods light green; quality superb, not excelled by any pea, and the

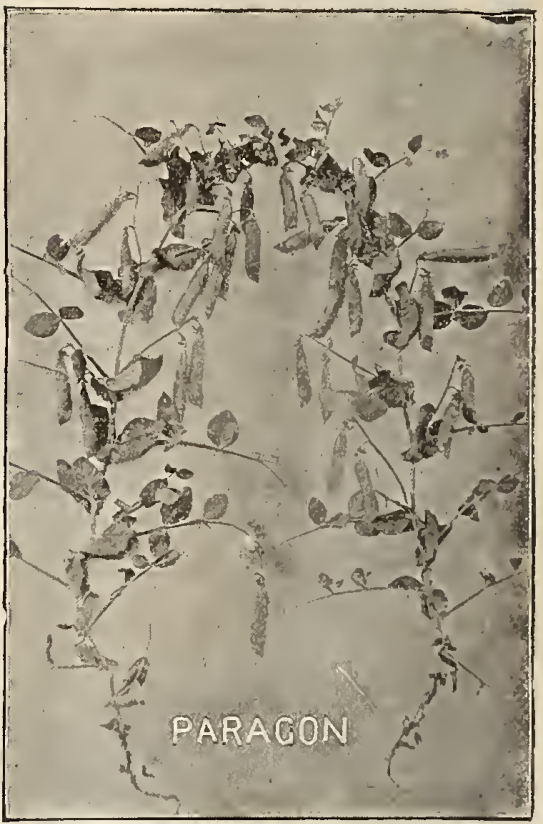
largest producer known.

This claim seemed to be fully borne out by test made in our trial grounds last season. Per packet, Io cts.; quart, $35 \mathrm{cts}$; peck, \$2.25.

\section{WONDERFUL PEA.}

The great demand we had for this pea last season was quite surprising, the supply of seed was somewhat limited, and it was offered in packets only. Following is the description of it that appeared in our 1893 Catalogue:

"It may be that this new variety will not find much favor with either market or private growers who wish to harvest a crop of well-filled pods only, but if it in a reasonable degree answers the originator's description, we think farmers who desire to increase the flow of milk or fatten stock economically, will find a valuable addition to their list of fodder and ensilage crops, as well as a plant that will improve the soil in which it is grown by collecting and storing nikrogen in its roots, which gradually decay and furnish plant food for succeeding crops. The originator says the plants make a growth of from twenty to forty feet and are literally covered with large pods, each containing about twenty peas of excellent quality both in the green state and dried. Per packet, Io cts.; quart, 25 cts.; peck, $\$ \mathrm{r} .50$.

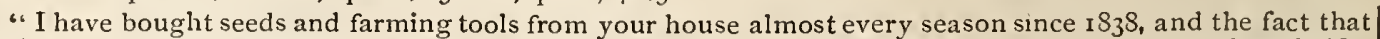
I a, n still a customer is evidence of quality and fair treatment in all dealings with you for more than half a century." 


\section{SHROPSHIRE HERO PEA.}

This valuable new, second-early wrinkled pea is a decided improvement on the old Yorkshire Hero. It is pronounced by market gardeners and others who have tested it, the greatest acquisition in new peas made in recent years. It is a robust grower, about three feet in height, producing its large pods in abundance, as shown in our cut. The pods are larger and better filled than Stratagem and others of its class, containing nine to ten fine large peas of exquisite flavor. It has been awarded a ñrst-class certificate by the Royal Horticultural Society of England. Per pkt., ro cts.; qrt., $30 \mathrm{cts.;} \mathrm{peck,} \mathrm{\$ 1.75.}$
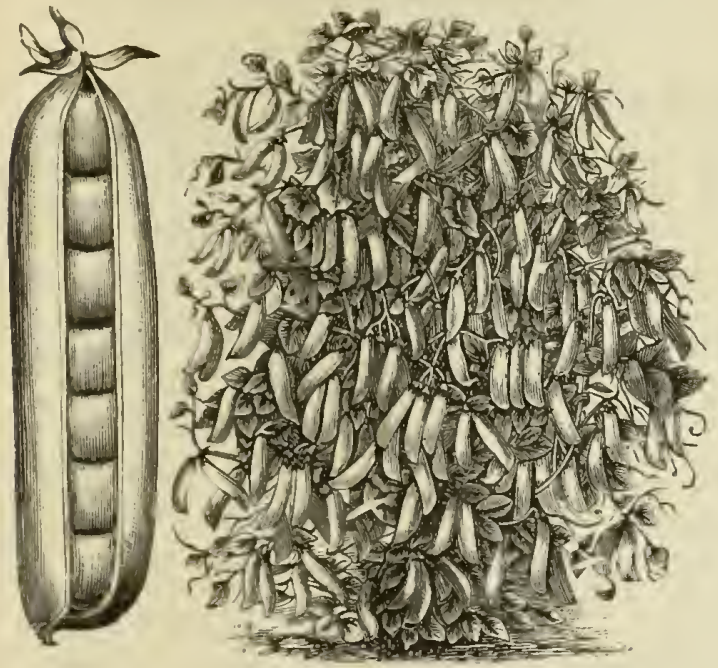

\section{KING OF THE DWARFS PEA.}

This is a seedling, selected as the most promising from forty different plants. In season it follows closely McLean's Little Gem, being intermediate. The vines are sturdy and remarkably vigorous, growing from eighteen to twenty inches high, bearing a profusion of pods, which are packed closely with large, smooth green peas of a most delicious flavor. On careful comparison, both as to number of pods and peas in the pods, with all of the principal dwarf varieties, including the American Wonder, we find that the King of the Dwarfs outyielded them all by 20 per cent.; all planted at the same time, in the same soil, and with equal cultivation, Per pkt., Io cts.; qrt., $30 \mathrm{cts.;} \mathrm{peck,} \mathrm{\$ 1.75.}$

\section{NEW PEPPER, - GOLDEN KING.}

The introducer says: We now oifer for the first time a superb new Golden Pepper, an exact counterpart, except in color, of the famous RUBY King PePPER, which has so steadily gained in popular favor the past nine years. Goldev KING was first found in 1886 in a crop of RUBY KING. Since then we have been carefully selecting and "training" a strain in which should be

inbred all the grand characteristics of RUBY KrNG. The beautiful, healthy plants bear large, handsome fruits, of a most attractive, bright golden-yellow, which shine out of the rich dark-green foliage. The Alavor is unsurpassed by any; exquisitely mild and pleasant, allowing the fruits to be even sliced like tomatoes or cucumbers, as an appetizing salad, while for stuffing or pepper hash they leave nothing to be desired. Per pkt., $10 \mathrm{cts}$; ; ounce, $35 \mathrm{cts}$.

\section{PIE SQUASH.}

The introducer says: This new squash has already become a favorite with market-men. It is exceedingly uniform in size and shape, and just the right size for retailing. It has been kept in one family for many years, and is preferred by them to any other for pies. The skin is russety and of a dark orange color, making the appearance very attractive. The flesh is very thick, making them so heavy that they appear to be perfectly solid. It is sweet, very fine grained, and is unexcelled for making pies. It is of great value to market gardeners, and we hope to see it generally distributed. The seeds are quite small, about the size of the Scallop Squashes. Per pkt., 5 cts.; ounce, $15 \mathrm{cts}$.; pound, \$1.25.
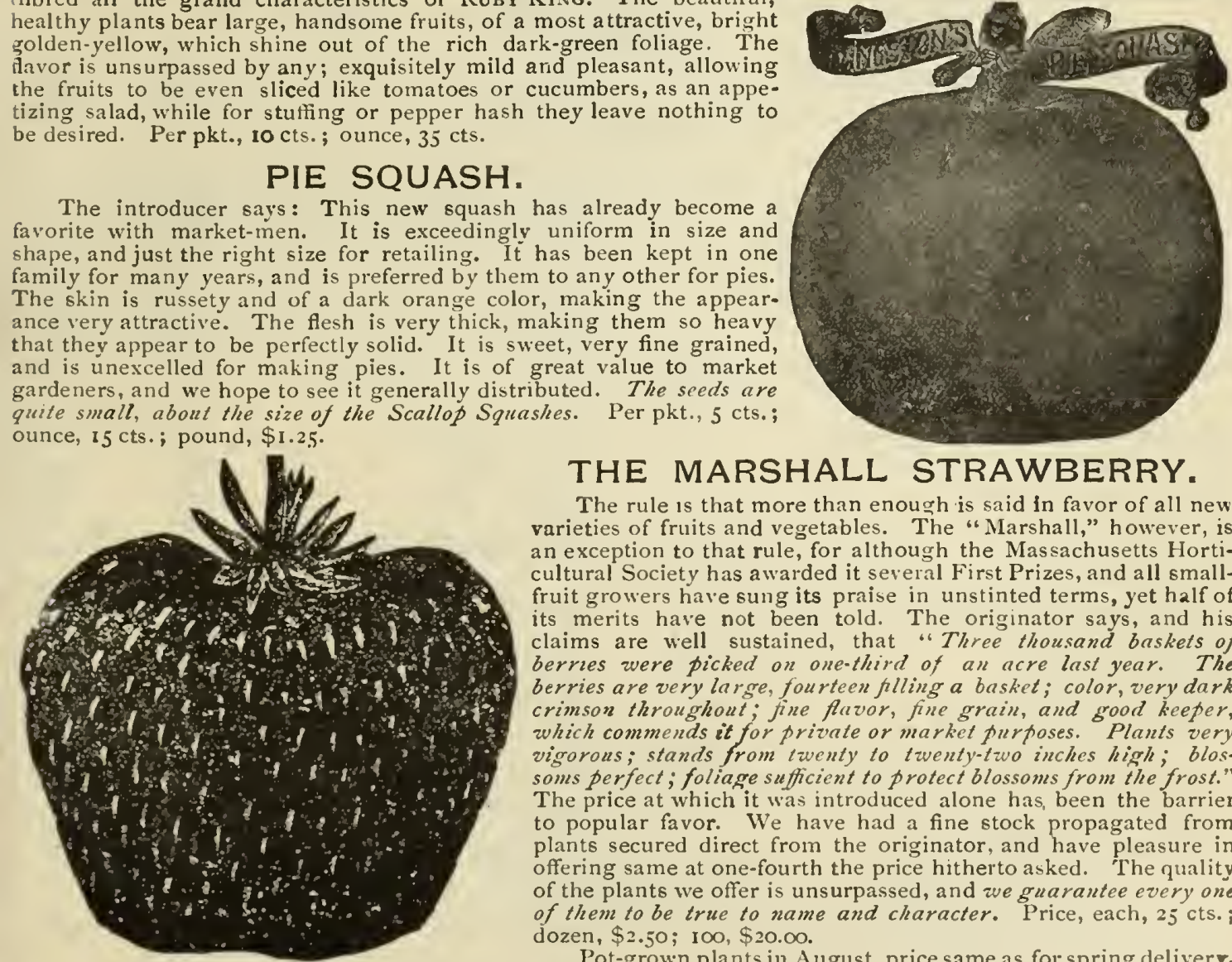

\section{THE MARSHALL STRAWBERRY.}

The rule is that more than enough is said in favor of all new varieties of fruits and vegetables. The "Marshall," however, is an exception to that rule, for although the Massachusetts Horticultural Society has awarded it several First Prizes, and all smallfruit growers have sung its praise in unstinted terms, yet half of its merits have not been told. The originator says, and his claims are well sustained, that "Three thousand baskets of berres were picked on one-third of an acre last year. The berries are very large, fourteen flling a basket; color, very dark crimson throughout; fine favor, fine grain, and good keeper, which commends it for private or market purposes. Plants very vigorous; stands from twenty to twenty-two inches high; blos. soms perfect; foliage sufficient to protect blossoms from the frost." The price at which it was introduced alone has, been the barrier to popular favor. We have had a fine stock propagated from plants secured direct from the originator, and have pleasure in offering same at one-fourth the price hitherto asked. 'The quality of the plants we offer is unsurpassed, and we guarantee every one of them to be true to name and character. Price, each, $25 \mathrm{cts}$. ; dozen, $\$ 2.50 ; 100, \$ 20.00$.

Pot-grown plants in August, price same as for spring delivery.

See Special Offers on third page of cover. 


\title{
BOOKS ON RURAL TOPICS.
}

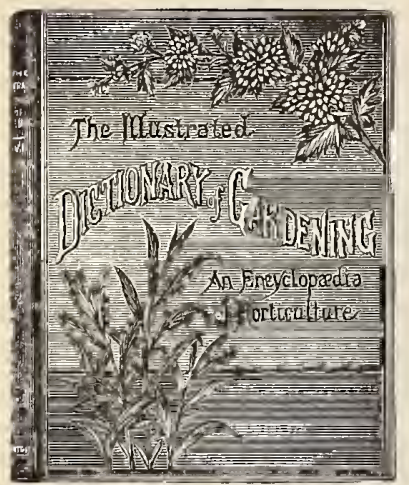

Play and Profit in My Garden

Gardening for Profit (new and enlarged edition).

Gardening for Pleasure.

Ornamental Gardening .

Money in the Garden

Practical Floriculture

Parsons on the Rose

Your Plants, and How to Grow Them

Lilies and Their Culture

Success in Market Gardening

The Tree Planter and Plant Propagator Fuller's Practical Forestry

Field Notes on Apple Culture

Barry's Fruit Garden

Fruit Culture

Fuller's Grape Culturist

Fruits and Fruit Trees of America

Small Fruit Culturist

Pear Culture

Cranberry Culture.

Allen's New American Farm Book

Farming for Profit

French's Farm Drainage.

Silos and Ensilage

How the Farm Pays

Ten Acres Enough

Farm Implements and Machinery

American Cattle

The Pig

Dairyman's Manual

Grasses and Forage Plants

Practical Poultry Keeper.

An Egg Farm

Practical Poultry Keeping

Elements of Scientific Agriculture

Injurious Insects of the Farm and Garden Quinby's New Bee Keeping

Lumber and Log Book

\section{A PRACTICAL ENCYCLOPEDIA OF HORTICULTURE.}

Edited by George Nicholson, of the Royal Botanic Gardens, Kew.

\begin{abstract}
With over 2,000 Illustrations and Colored Plates.
\end{abstract}
Everybody who has an interest in Horticulture, whether for pleasure or as a means fivelihood, should possess this work. It will pay for itself twice over in six months.

Price, complete, in four volumes, beautifully bound, gilt edges, $\$ 20.00$.

JosEPH BRECK \& SoNs, Boston, Mass., sole agents for New England.

\section{THE GARDEN.}

Rev. E. P. Roe

Henderson

Henderson

E. A. Long

Quinn.

Henderson

Samuel B. Parsons

Sheehan

Dr. Wallace .

W. W. Rawson

FOREST.

- Wood

\section{FRUIT.}

L. H. Bailey, Jr.
Barry :
W. C. Strong :
Fuller •
Downing
Fuller $:$
Quinn :
White

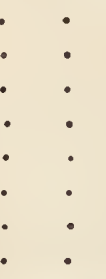

S. Fuller Publishers' J. Breck \& Sons'
Prices.

$\$ 1.50$

$\$$ I. 35

I. 80

I. 80

I.80

I. 35

I. 35

.90

.36

2.00

.90

.95

I.35

.68

.75

1.80

1.00

.90

I. 50

ז. 35

4.50

I. 35

I. 50

1.00

.90

I.13

1.25

THE FARM.

Richard L. Allen • • . 2.50

John E. Reed • • • • 3.75

Miles

.50

.45

2.25

1.00

.90

1.50

I. 35

Thomas

Allen

2.25

Harris

t. 50

I. 35

Stewart

1.80

2.00

2.00

1.88

\section{POULTRY.}

\author{
Wright \\ Stoddard
}

2.00

I. 80

.45

.45

MISCELLANEOUS.

.50 


\section{FREE} 粦櫒

\section{To Mail Order Customers.}

CASH CUSTOMERS, who order at one time, by mail, FLOWER OR VEGETABLE SEEDS IN PACKETS to the value of 50 cents, will receive a SIX MONTHS' PAID-UP SUBSCRIPTION TO "THE WHOLE FAMILY," a high-class Boston monthly magazine, replete with attractivu stories and useful information, of interest to every member of the household; or a copy of "MIY HANDIKERCHIEF GARDEN," by Charles Barnard, a practical work on gardening, valuable t" amateurs and others who have small lots of land in city or country.

Those making SIMILAR PURCHASES TO THE AMOUNT OF \$1.0o will receive ONE YEAR'S SUBSCRIPTION TO "THE WHOLE FAMILY," the numbers of which will be mailed direct as published.

Customers entitled to premiums will please advise which they wish to take advantage of.

These premiums are entirely FREE, and do not prevent patrons taking advantage of Special Offers shown on page 3 of cover.

\section{THE WHOLE FAMILY}

is the best popular Illustrated Magazine for the home. Every month it contains a large amount of instructive and entertaining reading for every member of the family.

Serials of great power and absorbing interest.

Short Stories of Romance and Adventure.

Humorous, interesting, and instructive Anecdotes.

\section{Monthly Question Contests, with}

\section{A S H PRIZ $\in$ S}

For Every Contestant.

\section{SCENES IN STRANGE LANDS.}

The Household.

Farm and Flowers.

Popular Science.
The Fashions.

Etiquette.

Woman's Work.
The Nursery.

The New Books.

Music.
Art.

Knots to Untie.

Sports and Pastimes.

SOME OF THF EDITOHS AND CONTRIBUTORS.

BRET HARTE, ELLA WHEELER WILCOX, LAURA E. RICHARDS, PROF. ELLIOTT COUES,
RUDYARD KIPLING, EDWARD BRECK, JULIAN HAWTHORNE, HEZEKIA11 BUTTERWORTH, See Special Offers on third page of cover.
OLIVER OPTIC, IGNACE PADEREWSKI, HERBERT WARD, ELIZABETH STUART PHELPS. 


\title{
NEW ENGLAND AGRICULTURAL WAREHOUSE AND SEED STORE.
}

ESTABLISHED 1822.

\author{
51,52, and 53 NORTH MARKET STREET, BOSTON, MASS.
}

\section{In the Interest of Employers and Employees in General.}

Early in I\$90, having long realized the necessity of such a mediurn, we established a Bureau of Registry and Information, whereby employers of labor in the lines of Horticulture and Agriculture could be put in coin. munication with RELIABLE persons seeking situations. The fact that NO PERSON was admitted to registration until he had been carefully looked up by us, together with our well-known respectability and responsibility, soon won the approval of employers and employees, and insured the usefulness of our new departure fiom the start; we were, however, but partially prepared for the success our Bureau soon achieved. As the public became aware of and appreciated the principles on which it was conducted, we began to receive inquiries for employees and for situations outside of the lines we originally intended to accommodate, and as these inquiries rapidly increased, we experimented, and the number of situations for book-keepers, cashiers, salesmen, clerks, shippers, porters, and boys, in almost every branch of business, satisfactorily filled by us, we believe fully warrant us in announcing to the public that we are prepared, through our Bureau of Registry and Information, to put employers of MALE HELP in every known occupation in communication with reliable persons seeking such positions.

A RECORD WILL BE KEPT of the names, addresses, and the present and future engagements of all applicants who prove to be qualified for registration. Particulars of actual experience and capabilities, salary expected, and testimonials from past employers will be on file.

PARTIES WISHING TO ENGAGE the services of reliable men in any position, or competent and reliable men desirous of filling any position, if of good character and habits, are respectfully invited to call or communicate with us.

BLANK FORMS, in which employers can state the particulars necessary to govern us in selecting suitable men, will be furnished on application.

APPLICANTS FOR SITUATIONS will fill out and sign registration blanks, which we will furnish, stating fully the kind of place and salary that they will accept. On receipt of the same properly filled out, the references given and former employers are written to, and if the replies are deemed satisfactory, the applicant's name will be entered on the register, when he will be entitled to all the benefits connected therewith, and put ir: communication with employers desiring such service as he seems capable of rendering.

WE DO NOT ORDINARILY GUARANTEE employment; neither do we, unless specially requested, negotiate with employers or with applicants for positions, as employers generally prefer to inake their own selections.

WE ARE, HOWEVER, prepared not only to guarantee employment, but to negotiate between employer and employee if desired. Circulars covering our conditions and terms in such cases will be furnished on application.

FOR POSITIONS OF TRUST or extra responsibility, we are prepared to furnish first-class insurance against dishonesty of employees, on the most reasonable terms. Full particulars on application.

WE OFFER PATRONS of the Bureau the conveniences of our store as a place where employer and employee can meet, and privacy will be insured if desired.

INQUIRY WIL.L BE MADE at least once each year of employers as to the charcter, habits, and general satisfaction given by employees obtained through our Bureau, so far as we are able to locate thein, and the reports kept on file.

WE RESERVE the right to remove the name of any applicant for a situation from the register at discretion.

A NOMINAL FEE will be charged to assist in maintaining the Bureau.

WE BELIEVE this Bureau has a tendency to improve and elevate the service, and supplies a long-felt want. We trust that both employers and employees will appreciate the efforts we are making in their behalf, and give our Bureau of Registry and Information their hearty coöperation.

Yours respectfully,

Copyright, $1890, b y$

Foseph Breck \& Sons.

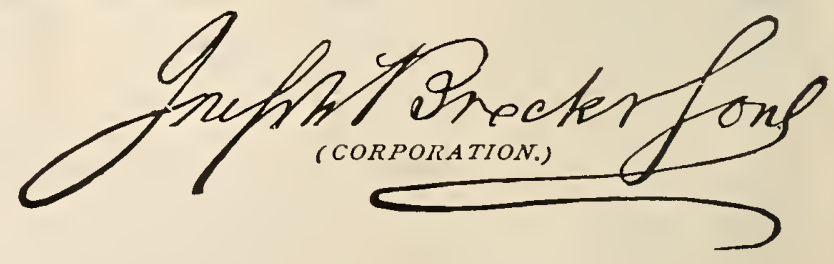

P.S. - We have recently added a

FEMALE MERCANTILE DEPARTMENT,

with experienced lady attendant, private rooms, etc., and are prepared to furnish approved female employees in all mercantile pursuits, such as book-keepers, cashiers, stenographers, salesgirls, forewomen, etc. 


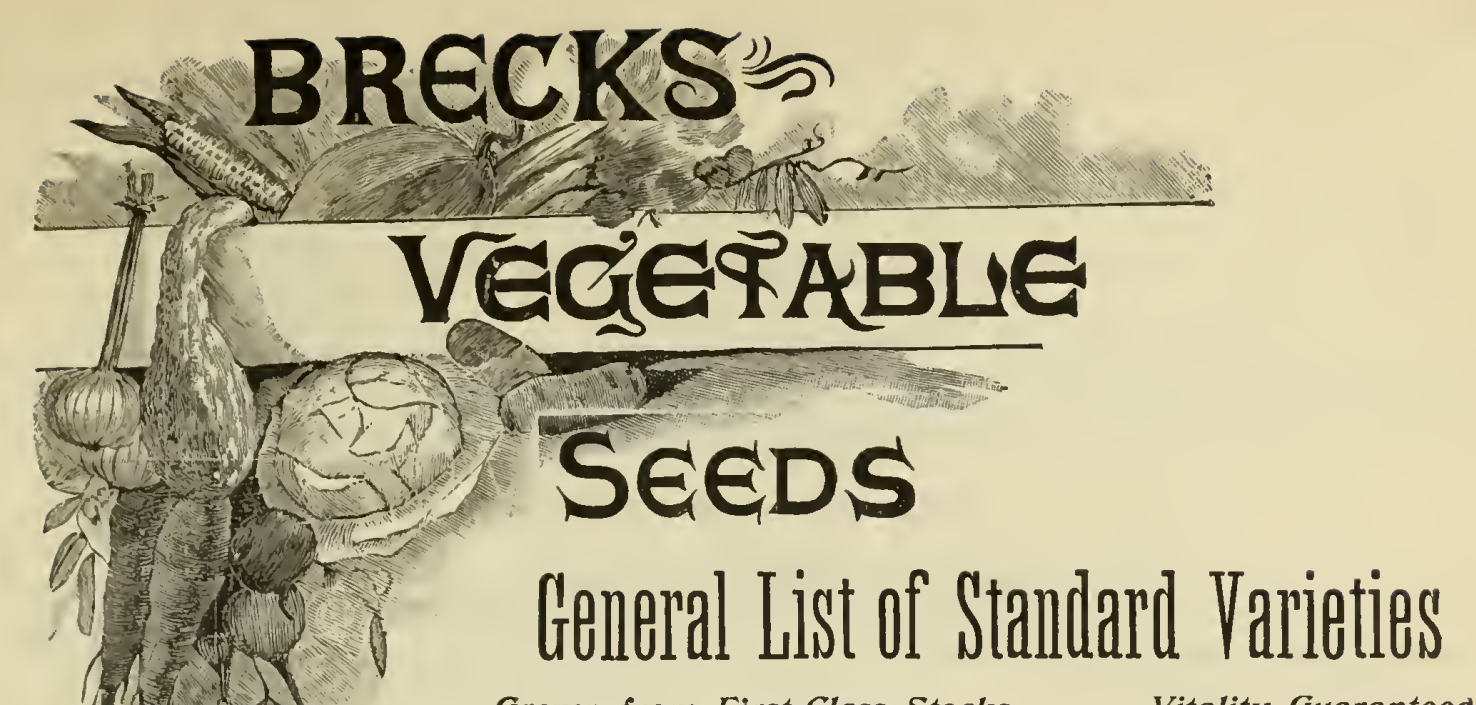

Grown from First=Class Stocks.

Vitality Guaranteed

Goods Delivered in your Town or City at Prices Quoted.

See Special Offers on Thirll Page of Cover.

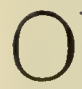

See speciat Offers on Third $P$

familiar with our establishment almost three-quarters of a century ago; their recommendations annually bring us new patrons. If our methods of doing business are unknown to you, some of your neighbors can tell you of them, and also of the quality of our seeds; inquire, and if results warrant it, send us a trial order. We supply only tested secds of varieties that experience has shown to be the best.

NoTE. - Prices may vary as the season advances. Ours will always be as low as the lowest for goods of equal quality.

\section{ARTICHOKE.}

\section{German, Artischoke. - French, Artichaut. - Spanish, Alcachofa.}

Culture. - Sow seed in April in drills I in. deep. Following spring transplant the young plants in rows $2 \mathrm{ft}$. plant to plant, $3 \mathrm{ft}$. between the rows. Mulch during dry weather. They prefer rich deep loam, and should be well manured every spring. One ounce of seed sows $30 \mathrm{ft}$. of drill.

LARGE GREEN GLOBE, grown for the unripe flower-heads, which are produced in abundance from May

to August. Packet, 5 cents; ounce, 25 cents; lb., $\$ 3.00$.

JERUSALEM, thrives best upon light, hard soil. Cultivated for pickles, also for feeding to sheep and swine.

Tubers per quart, 25 cents; per peck, \$1.00.

\section{ASPARAGUS.}

German, Sparget. - French, Asperge. - Spanish, Espárragos.

(For price on Asparagus Roots, see Vegetable Plants.)

An Asparagus bed may be made from one, two, or three year old roots, planted in October, or during April and May. The bed should be made very rich with well-rotted manure, and thoroughly worked over to a depth of nearly $2 \mathrm{ft}$. Plant the roots in rows $4 \mathrm{ft}$. apart, leaving about $12 \mathrm{in}$. between the plants in the row. Lay the roots flat in trenches, spreading them well, and asing care to have all the crowns placed in the same direction. Cover lightly at first, gradually filling the trenches as the plants grow.

Seed may be sown in April in drills $\mathrm{I}$ in. deep and I ft. apart. One ounce of seed sows bo feet of drill.

HUB ASPARAGUS, the best.

Conover's Colossal, large and excellent Moore's Giant Palmetto

(For Asparagus Plants, see under "Vegetable Plants.")

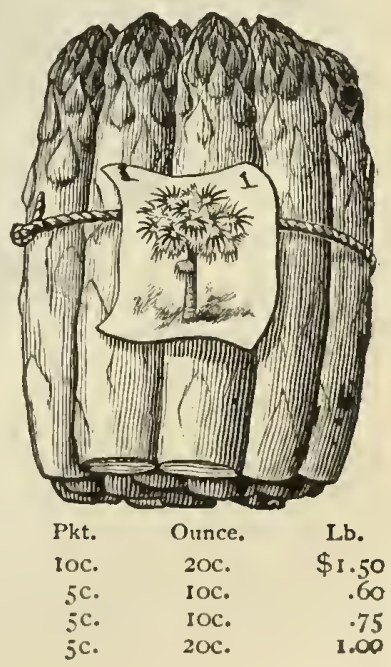

See Special Offers on third page of cover. 


\title{
BEANS. Dwarf or Bush.
}

\author{
German, Bohne. - French, Haricot. - Spanish, Frijorenano.
}

To afford a regular succession of crops throughout the season, plant every two weeks, from the middle of spring to the end of summer; but not until the soil becomes warm, as they are very sensitive to both heat and cold. Plant in rows, eighteen inches apart, two inches deep; cultivate frequently, but only when dry, as the scattering of earth on the foliage or pods, when moist, will cause them to become damaged with rust.

One quart will plant 100 -feet drill.

\section{GREEN-PODDED VARIETIES.}

Burpee's Bush Lima, a true bush form of the large Lima, productive and of excellent quality

Dreer's Bush Lima, a bush form of the Dreer's Improved $\dot{L}$ Lima, possessing all the good qualities of that sort

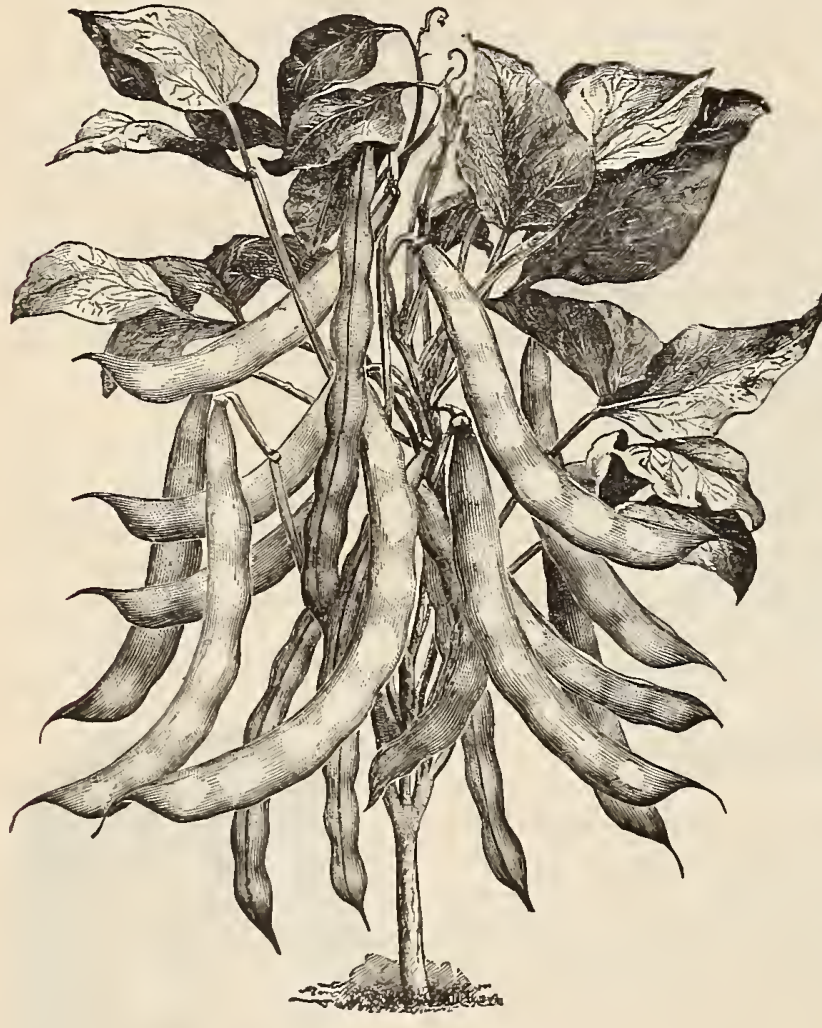

Henderson's Bush Lima, à bush variety of the small Lima or Sieva .

Long Yellow Six Weeks, an excellent generalcrop variety . .

Red Valentine Improved desirable for private and market gardens.

Early Mohawk, about the best early quality, ex-

Early China, early and good .

Refugee, or Thousand to One, the best pickling bean . i iarge,

Low's Champion, large, green, flat, stringless pods.

Red Cranberry, a stringless variety of great merit,

Breck's Dwarf Horticultural, unexcelled.

Dwarf Horticultural, one of the best shell beans

The Warren, excellent either as a string or shell bean .

Large White Marrow, used generally as a winter bean. $\dot{\text { Pea }}$ Bean,

Prolific Tree Pea Bean,
the best for baking. Yellow Eye Improved, a desirable winter bean,

Turtle Soup, the small black bean used for soup

\begin{tabular}{|c|c|c|}
\hline Pkt. & Qt. & Pk. \\
\hline .I 5 & .75 & $\$ 5.00$ \\
\hline . 15 & .75 & 5.00 \\
\hline . IO & .40 & 2.50 \\
\hline .10 & .30 & 1.50 \\
\hline . 10 & .30 & 1.50 \\
\hline . IO & .25 & I.25 \\
\hline . IO & .25 & 1.25 \\
\hline .10 & .25 & I. 25 \\
\hline . 10 & .30 & 1.50 \\
\hline .10 & $\cdot 30$ & 1.50 \\
\hline . IO & .25 & 1.25 \\
\hline .IO & .25 & I. 25 \\
\hline . IO & $\cdot 30$ & 1.50 \\
\hline . 10 & .20 & I. .0 \\
\hline .10 & .20 & 1.00 \\
\hline .10 & .20 & $1 . \infty$ \\
\hline . 10 & .25 & I.25 \\
\hline
\end{tabular}

\section{WAX-PODDED VARIETIES.}

Rust-Proof Golden Wax, none, more desirable Golden-Eyed Wax, almost rust-proof, quality good Kidney Wax, productive and desirable.

Yosemite $W$ ax, the pods are nearly all solid pulp. saddle-Back Wax very meaty and absolutely stringless Black Wax, pods waxy-yellow, thick and tender . White Wax, very tender and delicious

Retugee Wax, suitable for early or late planting 


\section{BEANS. Pole or Running.}

German, Stangen Bolıne. - French, Haricots à Rames. - Spanish, Fudias.

It is desirable to make the planting of Pole Beans at least a week later than

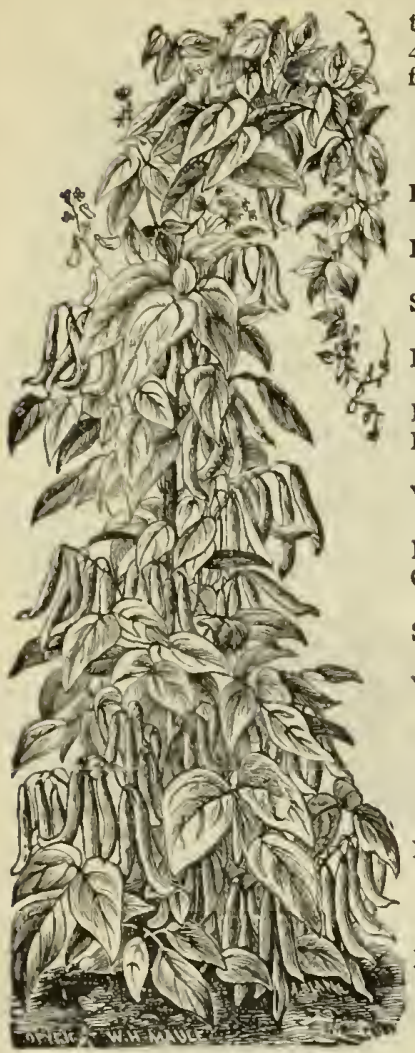

the first planting of the bush sorts, as they are more tender. Plant in hills 3 to 4 feet apart, putting four or five beans in a hill, and leaving space in the centre for the pole. A liberal quantity of well-composted manure in each hill is desirable.

\section{GREEN-PODDED VARIETIES.}

LARGE WHITE LIMA. This is considered the best of all pole beans

DREER'S IMPROVED LIMA, earlier than above, large and fine quality

SMALL LIMA, or Sieva, earlier than the preceding, beans smaller

RED POLE CRANBERRY, one of the earliest, quality unsurpassed.

HORTICULTURAL POLE, the most popular pole beans,

BROCKTON POLE, handsome, vigorous, productive, and fine quality.

WHITE CASE KNIFE, early productive, excellent flavor. Good green or dry

LAZY WIFE'S, entirely stringless, green pods, fine flavor,

CONCORD, or Parti-colored, excellent quality and very prolific.

SCARLET RUNNER, very ornamental flowers, early. An excellent string bean

$\begin{array}{llr}\text { Pkt. } & \text { Qt. } & \text { Pk. } \\ \text {.10 } & .40 & \$ 2.50 \\ \text {.10 } & .40 & 2.50 \\ \text {.10 } & .35 & 2.25 \\ \text {. I0 } & .35 & 1.75 \\ \text {.10 } & .30 & 1.75 \\ \text {.10 } & .30 & 1.75 \\ \text {.10 } & .30 & 1.75 \\ \text {.10 } & .30 & 1.75 \\ \text {.10 } & .30 & 1.75 \\ \text {.10 } & .30 & 1.75 \\ \text { I0 } & .30 & 1.75\end{array}$

WAX-PODDED VARIETIES.

EARLY GOLDEN Pkt. Ql. Pk.

CLUSTER, extra

early, productive,

of good quality

Golden Butter, ear-

liest of the wax pole varieties. Excellent

INDIAN CHIEF, or Black Wax, the most popular wax pole bean.

GIANT WAX, an old-fashion favorite yellow-podded sort .

\section{BEET.}

German, Runkel Rube. - French, Betterave. - Spanısh, Beteraga.

Sow from A pril to middle of June, in deep rich sandy loam, one inch deep, or in drills about one foot apart. Thin the young plants to the distance of six or eight inches, and fill up the vacant places with those taken out. The early turnip-rooted are the earliest, and are of fine quality. When young, the leaves make excellent greens. One ounce will sow fifty feet of drill.

EDMAND'S EARLY TURNIP, the best in shape, color, size, and

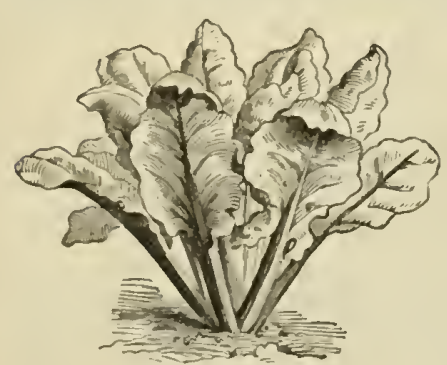
quality

CROSBY'S EGYPTIAN, as early as the original type, but thicker, smoother, and of better quality .

ECLIPSE, very early, dark-red color, small top, smooth roots.

EGYPTIAN, the earliest, good color, smooth turnip beet

DEWING'S EARLY BLOOD, a standard variety of excellent quality

EARLY BASSANO, the earliest of all; flesh almost White

EARLY BASTIAN, a quick, large-growing sort of good color

LONG SMOOTH BLOOD RED, an excellent late variety

SWISS CHARD SEA-KALE. This variety is cultivated solely for its leaves. The midrib is stewed and served as Asparagus, the other portion of the leaves beingused as Spinach

See Special Offers on third page of cover. 


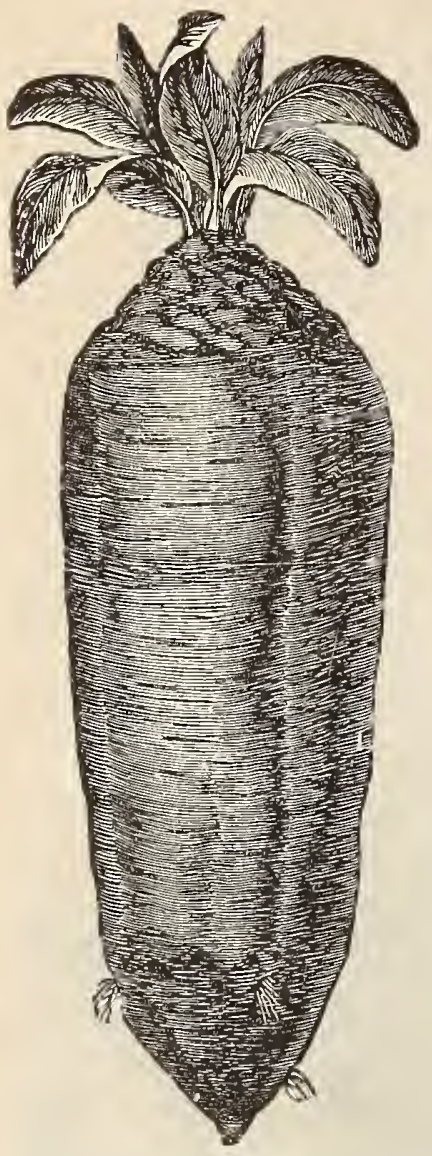

\section{MANGEL-WURZELS and SUGAR BEETS.}

Sow in April or May, six to eight pounds per acre. The value of these for stock-feeding cannot be overestimated; for sheep, dairy-stock, and fattening of cattle, experience has proved the Mangel-Wurzel to be at once healthful, nutritious, and economical. One ounce will sow 50 feet drill, 6 pounds per acre.

BRECK'S MAMMOTH LONG RED, a selection of the Pkt. Oz. Lb. long red variety. It is smoother skinned, finer grained, and heavier cropper. We consider it superior to all others

NORBITON GIANT, Long Red, a valuable variety:

GOLDEN TANKARD, a half-long variety of a bright yellow color.

LONG YELLOW, differs from long red only in color

KINVER YELLOW GLOBE, large globular-formed roots. Adapted for growing in shallow soils.

RED GLOBE, similar to Yellow Globe, except in color,

LANE'S IMPROVED SUGAR BEET, a well-known variety, valuable for feeding to cattle.

BRECK'S IMPERIAL SUGAR, an improved American-grown French Sugar Beet

\section{BORECOLE, or KALE.}

German, Blatterkohl. - French, Chou Vert. - Spanish, Breton.

Sow early in the spring in prepared beds, covering the seeds thinly and evenly; transplant in June, and treat in the same manner as for cabbage. They are extremely hardy, and will endure quite a low temperature. One ounce will sow 150 feet drill.

\section{WINTER or GERMAN}

GREENS, "Sprouts,"

should be sown in August or early in September in rows one foot apart, and treated as Spinach. They make Pkt. Oz. Lb. excellent spring greens, .05 . $10 \quad .75$

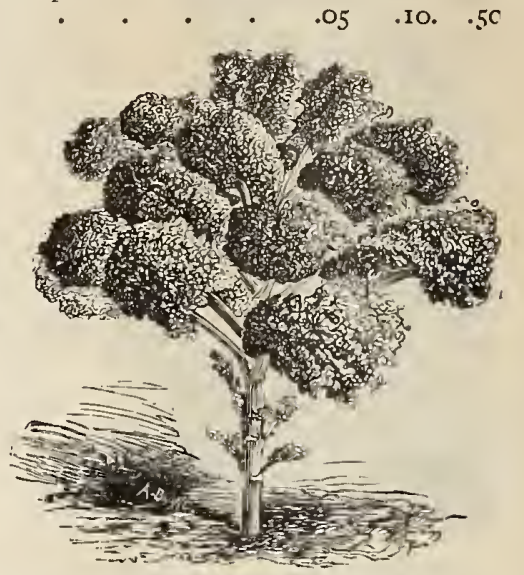

$.05 \quad .10 \quad .50$

$\begin{array}{lll}.05 & .10 \quad .50\end{array}$

$.05 \quad .10 \quad .50$

$.05 \quad .10 \quad .5 \mathrm{C}$

$\begin{array}{lll}.05 \quad .10 \quad .50 \\ .05 & .10 & .50\end{array}$

$.05 \quad .10 \quad .5 \mathrm{C}$

$.05 \quad .10 \quad .50$

$.05 .10 . \quad .5 \mathrm{C}$

DWARF GREEN CURLED SCOTCH, dwarf leaves of a bright green and very tender and closely curled. This variety should be sown in spring. The quality is improved if the plants are touched by the frost before being used.

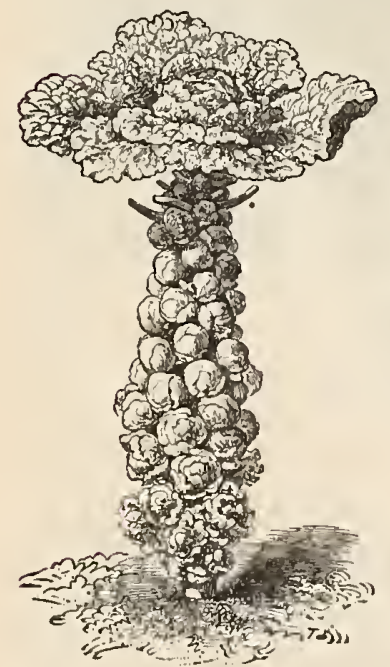

\section{BROCCOLI.}

German, Spargelkohl. - French, Chou Brocoli._Spanish, Bröculi. One ounce of seed produces about $I, 200$ plants.

This vegetable somewhat resembles the Cauliflower, but is hardier. In parts of the country where the thermometer does not fall below $20^{\circ}$ to $25^{\circ}$ Broccoli can be had from November until March. It succeeds best in a moist and rather cool atmosphere. The seed should be sown in May in a seed-pan and the plants afterwards set out in rows two and a half feet apart and eighteen inches between the plants.

WHITE CAPE, heads medium size, close, compact, and of a Pkt. Oz. Lb. creamy color.

EARLY PURPLE CAPE, harder than the preceding

WALCHEREN, a valuable late variety, with very large, fine heads

$\begin{array}{rrr}.10 & .30 & 3.00\end{array}$

$.10 \quad .40 \quad 4.00$

\section{BRUSSELS SPROUTS.}

German, Sprossenkohl. -French, Cloo de Bruxelles.-Spanish, Berza de Brusela.

Species of the Cabbage family. It produces along the whole length of the stem small sprouts resembling miniature cabbages. These heads are a great delicacy boiled in the same way as Cauliflower. Seed should be sown about the middle of May in a seed-bed, and the plants afterwards set out in rows two feet or more apart and cultivated like Cabbage. It is ready for use late in autumn after the early frost. One ounce of seed produces about $I, 200$ plants.

DWARF IMPROVED FRENCH, of sturdy compact growth. Packet, 5 cts.; ounce, 20 cts. ; pound, \$2.50. IMPROVED PARIS MARKET, a most desirable strain. Packet, 5 cts.; ounce, 20 cts.; pound, \$2.50. 


\section{CABBAGE.}

German, Kofflohl. - French, Chou Pomme. - Spanish, Berza.

(For price on Cabbage Plants, see Vegetable Plants.)

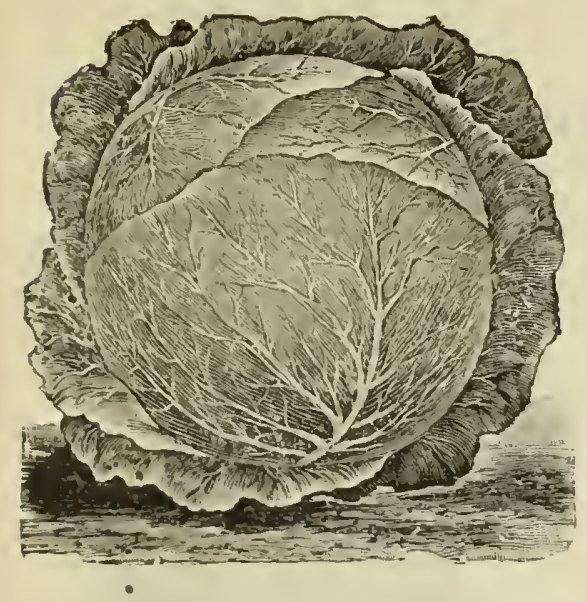

EARLY ETAMPES, one of the earliest WINNINGSTADT, a conical-shaped variety,

EARLY YORK, a well-known, fine-flavored early variety

HENDERSON'S SUCCESSION CABBAGE. Valuable second and late crop variety.

ALL SEASONS, an early Drumbead variety, WARREN-STONE-MASON, an improved strain of Stone Mason, nearly as early as Fottler's Brunswick, rounder in shape and extremely solid

STONE MASON DRÜMHEAD, a wellknown winter Cabbage of excellent qualits, FOTTLER'S IMPROVED BRUNSWICK, a short-stemmed early Drumhead

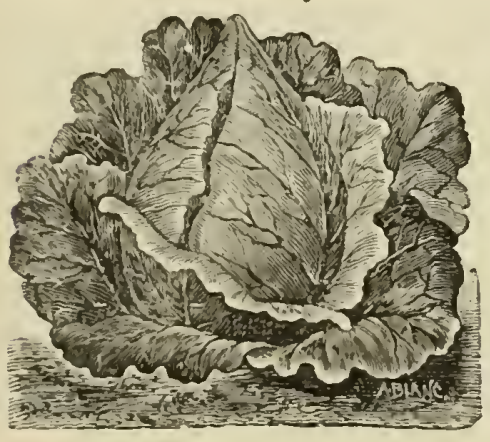

\section{MARBLEHEAD MAMMOTH DRUMHEAD,} the largest variety of Drumhend. Heads often Pkt. Oz. Lb. weigh fifty pounds

BRECK'S PREMIUM DRUMHEAD, recommended for its immense size and sure heading qualities, BRECK'S PREMIUM FLAT DUTCH. This we consider superior to any late cabbage . .

DRUMHEAD SAVOY, the largest of this class

AMERICAN IMPROVED SAVOY, the best of all winter cabbages

ENGLISH CURLED SAVOY' (for greens). Used only to sow early in spring for greens

PERFECTION RED, superior in size and quality to all other red varieties

RED DUTCH, or PICKLING, an oid but desirable sort for pickling

\section{CARROT.}

German, Möhre. - French, Carotte. - Spanish, Zauahoria.

Carrots are grown largely both for feeding to stock and culinary purposes; the long varieties used for the former, the "Horn" and medium sorts for the latter. The "Horn" sorts can be grown on thin soil and are mostly for early use. The others prefer deep, sandy loam that was well-manured the previous year for some other crop, such as potatoes or onions. Sow in April or May in drills about one incl deep and fifteen inches apart. Thin out the plants from three to eight inches apart, according to variety. One ounce of sced is sufficient for one hundred feet drill, four pounds to an acre.

EARLY SCARLET FORCING, very early and valuable for forcing

EARLY SCARLET HORN, a medium-sized, half-long variety of fine color

GUERANDE, heart-shaped, intermediate between half-long and Horn sorts

DANVERS HALF LONG, the most desirable main crop variety; an excellent keeper

LONG ORANGE IMPROVED, a large, long-rooted variety, suitable for table or stock.

LARGE WHITE BELGIAN, the largest and most profitable for feeding to stock

See Special Offers on third page of cover.
$.05 \quad .25 \quad 2.5 \mathrm{C}$

$.05 \quad .30 \quad 3.00$

$.05 \quad .10 \quad .75$

$.10 \quad .40 \quad 4.00$

$\begin{array}{lll}.05 & .25 & 2.5 C\end{array}$
$.05 \quad .25 \quad \$ 2.5 \mathrm{C}$

$.05 \quad .25 \quad 2.5 C$

$.05 \quad .30 \quad 3.00$ 


\section{CARDOON.}

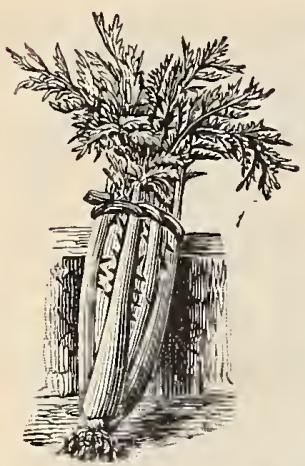

German, Kardon. - French, Cardon. - Spanish, Cardo Hortense.

Cardoon is grown for the midrib of the leaf, which requires to be blanched in the same manner as celery. Sow early in spring, where the plants are to remain, in drills three feet apart and an inch and a half deep, and thin out the young plants to a foot apart in the drills.

\section{LARGE SPANISH \\ CAULIFLOWER \\ $\begin{array}{lll}\text { Pkt. } & \text { Oz, } & \text { Lb. } \\ \text {. IO } & .30 & \$ 3.00\end{array}$}

German, Blumenkohl. - French, Chou-feur. - Spanish, Coliflor.

(For price on Cauliflower Plants, see Vegetable Plants.)

Cauliflower is the most delicate and delicious of the cabbage family. For the production of the Cauliflower a rich, deep loam is required, a low moist situation being preferable. A liberal supply of water when possible produces very marked results. Seed of the early variety should be sown in a hot-bed in February or March. For later supply, sow seed in May, choosing a cool, moist place. When large enough, transplant, making the rows about $2 \frac{1}{2}$ feet apart, and 18 inches between the plants: Transplanting should be done in moist weather. One ounce of seed produces about 2,500 plants.

BRECK'S WHITE BOUQUET. This we believe the earliest and most reliable Cauliflower for New England. Since its introduction it has become an especial favorite with the market gardeners a round Boston

EARLIEST DWARF ERFURT, a very choice strain of the well-known Erfurt Cauliflower

EARLY SNOWBALL, a reliable early variety, grown largely for market

EARLY DWARF DANISH, a variety of the Erfurt from Denmark. It matures evenly and is a reliable header

EARLY PARIS, an old but still popular sort

VEITCH'S AUTUMN GIANT, a desirable large, late variety.

\section{CELERY,}

German, Sellerie. - French, Céleri. - Spanish, Apio. (For price on Celery Plants, see Vegetable Plants.)

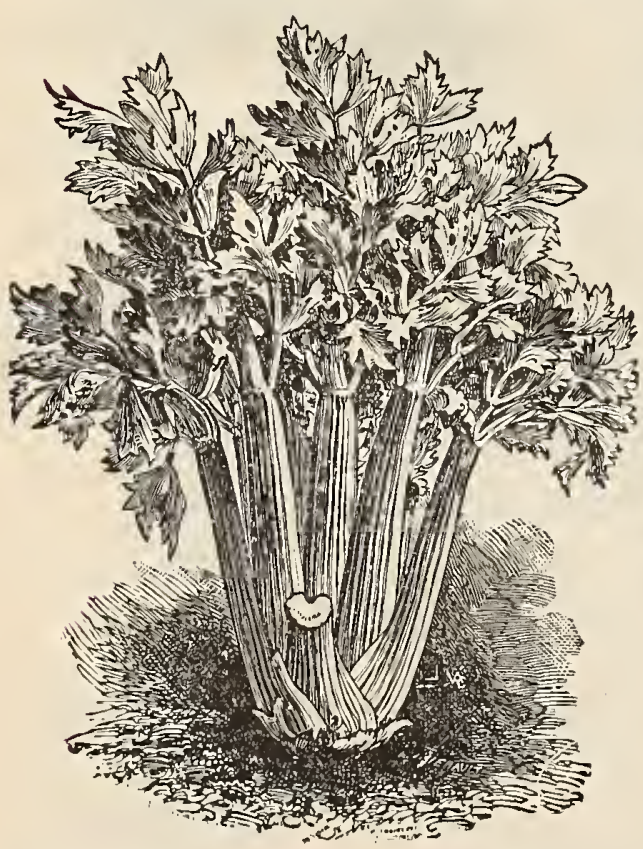

Sow seed the first or second week in April in hotbed or cold-frame. As soon as the plants have at-

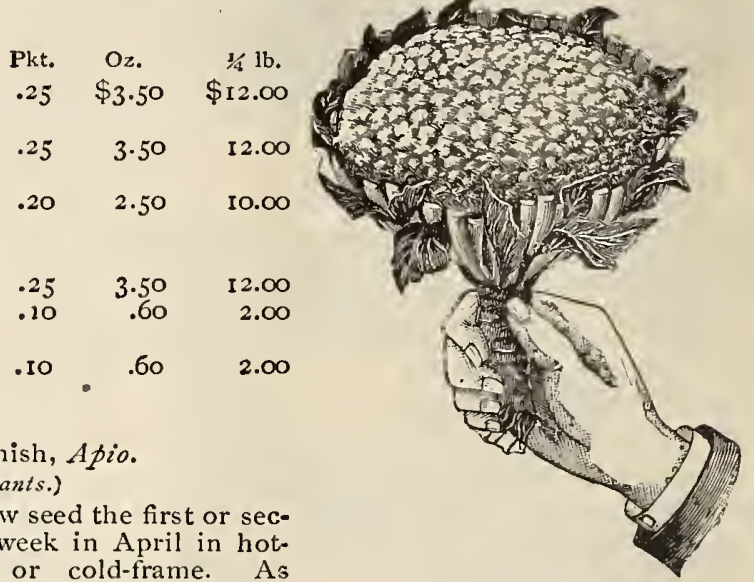

tained a height of three inches, transplant in prepared border, setting them four inches apart. In order to secure "stocky" plants, cut off the tops once or twice before transplanting into richly manured soil, in rows four feet apart, and from seven to nine inches plant to plant. Keep down all the weeds, and as fall approaches draw earth up to the plants, keeping the stalks well together. When well blanched it is ready for use. For winter use it is usually placed in frames and covered with litter, or stored in cold cellars. Some of the varieties, such as Golden Self-Blanching and White Plume, may be blanched by simply placing a board twelve to fifteen inches wide on edge on each side of the row, and to hold them in place tack bits of laths across the rows at the top. One ounce of seed produces about 3,000 plants.

BOSTON MARKET, the best and most popular sort in cultivation.

EARLY ARLINGTON, excellent for OLDEN SELF-BLANCHING, a self-blanching early golden-colored variety that is very popular

WHITE PLUME. This variety can be blanched with boards. It is solid, and of a pleasing nutty flavor.

GIANT PASCAL, a sport from Golden Self-Blanching. A strong grower and wonderful keeper

SANDRINGHAM, a dwarf white variety, solid, crisp, and fine-flavored

CARTER'S DWARF CRIMSON, solid, crispy, and fine-flavored

CELERIAC, or TURNIP-ROOTED. The turnip-shaped roots of this variety are cooked and sliced and used with vinegar, making a most excellent salad

CELERY SEED FOR FLAVORING

$\begin{array}{rrr}\text { Pkt. } & \text { Oz. } & \text { Lb. } \\ \text {.10 } & .30 & \$ 3.50 \\ .10 & .30 & 3.50 \\ & & \\ .10 & .40 & 4.00 \\ & & \\ .10 & .35 & 4.00 \\ & & \\ .10 & .35 & 4.00 \\ .05 & .30 & 2.50 \\ .05 & .30 & 2.50 \\ .05 & .20 & 2.00 \\ .05 & .10 & .50\end{array}$




\section{CORN. - Sweet.}

German, Mais. - French, Mais. - Spanish, Maiz.

A rich, warm soil is best, especially for the earlier varieties, which ordinarily should not be planted before the middle of May. Successive plantings may be made until July. Plaut in hills three or four feet apart each way, according to the height of the variety. One quart will plant about zoo hills.

Selected Ears, Five Cents each, except as noted.

CROSBY, Josiah Crosby's strain Pkt. Qt. Pk.

EARLY MAINE, earliest white-cob variety in cultivation. . . .

EARLY CORY, earliest of all the redcob varieties.

EARLY MARBLEHEAD, a variety similar to Cory

FIRST CROP SUGAR, an extra early eight-rowed variety of good quality.

BRECK'S PREMIER, large, medium early, unequalled in quality

MOORE'S CONCORD, ears large and weli filled, early, and unsurpassed for richness

BLACK MEXICAN, said to be the sweetest coin in cultivation.

POTTER'S EXCELSIOR, perhaps the best and sweetest main-crop variety.

NE PLUS ULTRA, medium-sized ears, very long kernels.

EGYPTIAN, a very large late variety, exceedingly sweet and superior.

MAMMOTH SUGAR, a late variety, produces ears larger than any other
STOWELL'S EVERGREEN, the standard late variety

COUNTRY GENTLEMAN, a large and later Ne Plus Ultra

$\begin{array}{lll}\text { Pkt. } & \text { Qt. } & \text { Pk. } \\ \text {.10 } & .25 & \$ 1.25 \\ \text {.10 } & .25 & 1.25 \\ \text {.10 } & .25 & 1.25 \\ \text {.10 } & .25 & 1.25 \\ .10 & .20 & 1.00 \\ \text {.10 } & .25 & 1.25 \\ .10 & .25 & 1.25 \\ \text {.10 } & .20 & 1.00 \\ .10 & .25 & 1.25 \\ .10 & .25 & 1.25 \\ .10 & .25 & 1.25 \\ .10 & .25 & 1.25 \\ .10 & .25 & 1.25 \\ .10 & .25 & 1.00 \\ .10 & .25 & 1.25\end{array}$

\section{CORN. - Field.}

VARIETIES FOR FIELD CULTURE.

Speciul Offer No. 2 only applies to Field and Fodder Corns.

ANGEL OF MIDNIGHT, the earliest and best yellow flint variety

LONGFELLOW. eight-rowed yellow flint, long ears with small cob

EARLY YELLOW CANADA, wellknown early, eight-rowed flint variety,

EARLY SANFORD, a white flint variety, equally valuable for ensilage or grinding

LEAMING a yellow dent variety, very valuable for ensilage

GOLDEN BEAUTY, a tall-growing leafy dent variety, suitable for ensilage,

PRIDE OF THE NORTH. This variety can be successfully grown farther north than any other dent corn. Grown for ensilage or fodder

BRECK'S BOSTON MARKET. 'This Qt. Pk. Bu. $.20 \quad .75 \$ 2.50$ $.15 \quad .60 \quad 2.00$

$.15 \quad .60 \quad 2.00$

$.15 \quad .60 \quad 2.00$

$.15 \quad .60 \quad 2.00$

$.15 \quad .60 \quad 2.00$

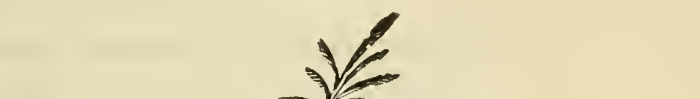

variety is now so well known that it is scarcely necessary for us to say that it is especially adapted for the purpose of ensilaging. More than a dozen different agricultural experiment stations in the States have indorsed $i t$, as have also thousands of successful farmers, P. \& W. PERFECT MAMMOTH ENSILAGE, a well-known ensilage variety BLUNT'S PROLIFIC, an early eight-rowed heary dent variety

RED COB ENSILAGE, an excellent fodder and ensilage sort

WHITE SOUTHERN, an immense cropper, valuable for ensilage and fodder

EVERGREEN SWEET FODDER. For cutting green and feeding to stock this variety excels all others in tenderness, sweetness, and nutriment. Also popular as a silo variety

WHITE RICE, selected ears for seed purposes, 3 cts. per ear.

POP_CORN WHITE PEARL, selected ears for seed purposes, 3 cts. per ear.

EIGHT-ROWED WHITE, selected ears for seed purposes, $3 \mathrm{cts}$. per ear.

TATTOOED YANKEE POP-CORN, per pkt., 5 cts.

Special Offer No. 2 only afflies to bolh Ensilage and Cob Corn.

See Special Offers on third page of cover.

Qt. Pk. Bu.

$.15 \quad .60 \$ 2.00$

$\begin{array}{lll}.15 & .50 & 1.75\end{array}$

$.15 \quad 50 \quad 1.75$

$.15 \quad .50 \quad I .50$

I.25

$\begin{array}{lll}.15 & .75 & 2.25\end{array}$ 


\section{CORN SALAD, or FETTICUS.}

German, Lammersalat. - French, Macke. - Spanish, Macha Valerianilla.

Used as a salad. It is sown very early in spring, in rows one foot apart, and is fit for use in six or eight neeks. For early spring use sow in September, and winter in cold-frames, or cover with litter. One ounce will

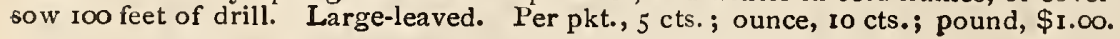

\section{CRESS.}

\section{German, Garten und Brunnen Kresse. - French, Cresson. - Spanish, Mastuerzo.}

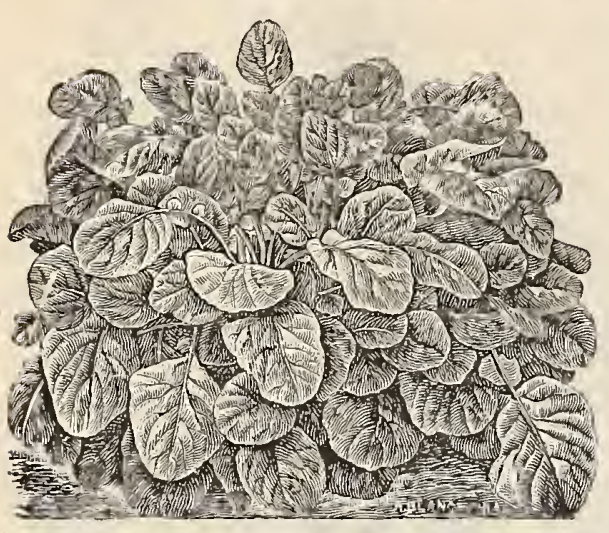

Sow early in the spring and at intervals throughout the season, for a succession, thickly in shallow drills, as it soon runs to seed. The Water Cress requires a stream of running water, ditch, or pond, in which it will grow without care, except at first keeping weeds from interfering with it. It is easily introduced by planting along the margins of ditches or streams, and increases rapidly by the spreading of the roots or from the seed.

Extra Curled, or Peppergrass, fine flavor, and can be cut severai times . . . . Erfurt Water, True, a perennial aquatic plant, Upland Cress, a hardy perennial, can be eaten raw or as a salad .. . . . . .

$$
\begin{array}{lll}
\text { Pkt. } & \text { Oz. } & \text { Lb. } \\
.05 & .10 & \$ 0.50 \\
.10 & .40 & 4.00 \\
.10 & 1.00 &
\end{array}
$$

\section{CUCUMBER.}

German, Gurken. - French, Concombre. - Spanish, Pepino.

The first planting should be made early in May on partly spent hot-beds; inverted sods form an excellent medium for oth planting on and for carrying the young plants to their permanent location, or small pots can be used. Such plantings are usually ready for transplanting to the open ground in from three to four weeks, and are seldom troubled with the striped bug. Transplanting, when practical, should be done in the evening, into hills four feet apart each way. Thin out to about four plants to a hill when established. The seed may be planted in hills late in May, thus giving a succession. For pickles, plant during the last two weeks of June.

Plaster Dust, or an infusion of Hellebore powder in water, will destroy the striped bug.

One ounce will plant about fifty lills.

EARLY RUSSIAN. The earliest variety. About four inches long EARLY CLUSTER. Grows in clusters. Bluioh-green color EARLY FRAME. Of medium size. Valuable for both table and pickling IMPROVED WHITE SPINE. The best table variety, of excellent quality. IMPROVED LONG GREEN. The standard late variety. Productive and gosd TAILBY'S HYBRID. A cross between White Spine and an English Fmene sort EVERBEARING. Medium size, early, and productive BOSTON PICKLING. Produces an abundant crop of short, dari-green fruit . WEST INDIA GHERKIN. A short green oval.

\section{ENGLISH FRAME VARIETIES.}

These are mostly grown by private gardeners. They attain a length of from twelve to thirty inches, and are of fine quality. ROLLINSON'S TELEGRAPH. B!UE GOWN. CARTER'S MODEL. Each, per jacket, 25 cents.

\section{DANDELION.}

\section{German, Pardeblum. - French, Pisse-en-lit. - Spanish, Amargon.}

The Dandelion is cultivated for spring greens, or for blanching for salad.

Sow seed in May or June, in drills half an inch deep and :welve inches apart. Cultivate, to keep down the weeds during summer, and upon the approach of severe weather cover with litter, which should be removed early the following spring.

One ounce will sow 200 feet of drill. One lb. will sow an acre. AMERICAN IMPROVED. A fine home- Pkt. Oz. Lb.

grown variety . . . . . . $40 \quad \$ 4.00$ THICK-LEAVED FRENCH. Large and

tender

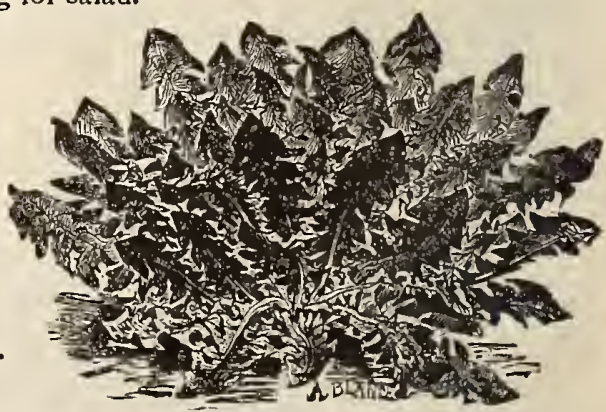

\section{EGG-PLANT.}

German, Eierpfanze.-French, Aubergine.-Spanish, Berengena. (For price of Plants, see Vegetable Plants.)

Pkt. Oz. Lb. .05 . Io $\$ 0.75$ $.05 \quad .10 \quad .75$ $.05 \quad .10 \quad .75$ $.05 \quad .10 \quad 1.00$
.05 $.05 \quad .10 \quad 1.00$ $.05 \quad .10 \quad 1.00$
.05 $\begin{array}{lll}.05 & .10 & 1.00\end{array}$ .05 . I0 1.00 $\begin{array}{lll}.05 & .15 & \mathrm{I} .50\end{array}$

Sow the seed in hot-beds the first week in April, care being taken to protect the young plants from cold at aight. Plant out about June $I$, about two and a half feet apart. One ounce will produce about $I, 000$ plants.

NEW YORK IMPROVED, the leading market variety; excellent and very productive . Pkt. Oz. Lb. Early Long Purple, differing in shape from the foregoing; early, hardy, and productive 


\section{ENDIVE.}

German, Endivien. - French, Chicoréc. - Spanish, Endivia.

Sow for an early supply about the middle of April. $\Lambda$ s it is used mostly in the fall months, the main sowings are made in June and July, from which plantations are formed at one foot apart each way, in Augusi and September.

As it is generally used for salads, it should be blanched by tying all the leaves into a bunch at the extreme top. One ounce will sow 150 feet of drill.

Broad-Leaved Batavian, used for soup and salads, the best variety

Pkt. Oz. Lb. Green Curled, a nicely curled sort

$.05 \quad .20 \quad \$ 2.00$

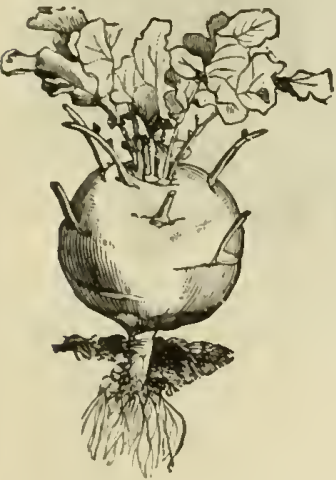

\section{KALE: See Borecole. KOHL RABI (Turnip-Rooted Cabbage).}

German, Kohl-Rabi. - French, Chou-Rave. - Spanish, Col de nabo ó Nabicol.

An intermediate vegetable between the Cabbage and Turnip. Sow in April, in rows is inches apart, and thin out or transplant in rows 8 inches apart. When 3 to 4 inches in diameter they are fit to eat For late use, sow in June and July. One ounce will sow 150 feet of drill. Early Purple Vienna, differing from the above in color

\section{LEEK.}

German, Lauch. - French, Poireau.-Spanish, Puerro.

Makes a valuable second crop on land that has been used for cabbage, etc., but the soil should receive a liberal dressing of well-composted manure before being planted. Sow the seed in April, in rows I foot apart, and transplant in July. Transplant quite deeply into rows 15 inches apart, with 6 inches between the plants. Hoe up the earth around the stems when they begin to grow, so as to blanch and make them tender. One ounce of seed will sow 100-foot drill.

MUSSELBURGH, or Scotch, grows to a large size; fine quality LONDON FLAG, a hardy sort

\section{LETTUCE.}

German, Lattich-Salat. - French, Laitue. - Spanish, Lcchuga.

(For price on Lettuce Plants, see Vegetable Plants.)

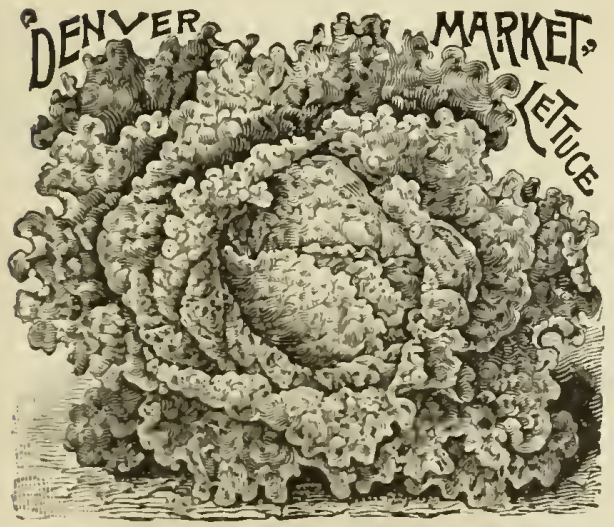

The most easily grown of all open-air plants used for salads. It requires a warm soil that has had a liberal dressing of well. rotted manure and abundant moisture. To be of a satisfactory quality, the growth should be rapid and vigorous. Seed may be sown in a frame in February or March, the plants set cut as early. as the ground can be worked, as light frosts will not injure them. Set the plants 9 inches apart in the rows, and 18 inches between the rows. For successive crops, sowings may be made every two weeks up to the end of August. Onc ouncc of seed will produce about four thousand plants.

DENVER MARKET, an early head variety. with blistered leaves like the Savoy Cabbage

Big Boston. a larger Boston Market.

Breck's Boston Market, a superior selection of White-Seeded Tennis Ball, grows very compact, and is a most profitable forcing variety

Black-Seeded Tennis Ball, well-formed heads; one of the best for out-door culture; compact and tender.

Black-Seeded Simpson, one of the best for out-door culture

Boston Curled, esteemed for its earliness, beauty, and good table qualities

Hanson, one of the best in cultivation, large, solid, heavy, crisp heads

All the Year Round, an excellent summer Lettuce, also valuable for forcing

Early Curled Simpson, forms a compact mass of tender leaves of a yellowish-green color. Early Prize Head, large, hardy, and tender

White Summer Cabbage, large, extra tender, and keeps well

Trocadero, one of the finest liead or package lettuce

Paris Cos or Romain, a sort with long, narrow upright leaves. When tied up blanches nicely and bears close planting

$\begin{array}{ccc}\text { Pkt. } & \text { Oz. } & \text { Lb. } \\ .05 & .30 & \$ 3.00 \\ .05 & .20 & 2.00\end{array}$




\section{MARTYNIA.}

The seed-pcds are used for pickling, and should be gathered when green and tender. Plant in the open ground the last week of May in rows two feet apart, making hills one foot apart in the rows; place several seeds in each hill, and when well up thin out to one plant. One onnce will plant fifty hills.

Martynia Proboscidia . . . . . . . . . . . $\begin{array}{cccc} & .40 & \$ 4.00\end{array}$

\section{MELON (Musk).}

German, Melone.-French, Melon.-Spanish, Melon.

Melons prefer a warm, light, sandy loam; being tender plantings, should not be made before middle of May. Plant about six seeds, half-inch deep, in hills five to six feet apart each way. The hills should have at leas $t$ a peck of well-rotted compost thoroughly

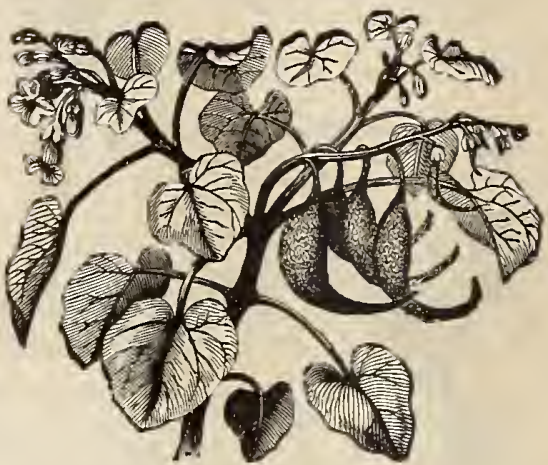
stirred into each of them before the seed is planted. When well grown thin out to three plants in a hill. If an earlier crop than this method of cultivation allows is desired, the directions given for growing early cucumbers may be followed.

One ounce will plant about sixty hills. Two pounds will plant an acre.

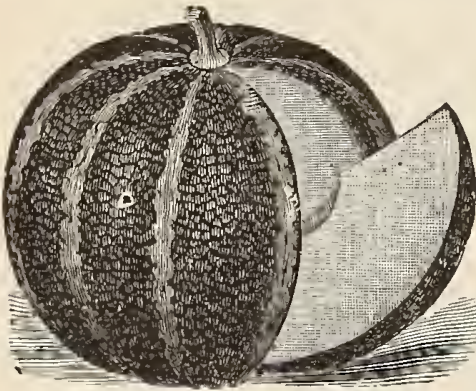

Bay View Cantaloupe, large size, green flesh, fine

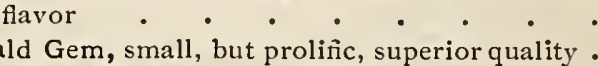

Emerald Gem, small, but prolinic, superior quality
Breck's Improved Emerald Gem, beautiful, large, almost smooth, green variety, with very solid orange flesh of unequalled quality . . .

Montreal Green Nutmeg, early, large size, excellent quality

Prolific Nutmeg, thick, green flesh, with honey flavor Surprise, bright-yellow flesh, musky flavor, medium size.

Hackensack Improved, large, productive, and fine flavored . Early Christiana, green, with yellow fiesh, an excellent early sort Casaba, large size, green fiesh, fine quality

Large Yellow Musk, large, flesh salmon-yellow, very sweet .

White Japan, early, medium size, skin cream-white

Mango, for Pickles, small, used in the green state .

\section{MELON (Water).}

Frencl, Melon d'eau. - German, Wassermelone. - Spanish, Sandia.

Water Melons require the same general treatment as Musk Melons; but being more tender they should have the best possible exposure. The hills should be eight feet apart.

One ounce for thirty hills; five pounds for an acre.

Phinney's Early, a standard sort for N. E., bright-red fiesh, sweet and tender Black Spanish, scarlet flesh, thin rind, sugary flavor Mountain Sweet, one of the best for general culture Ice Cream, medium size, solid, scarlet flesh, fine flavor . Green and Gold, a large early variety, of fine quality . Ruby Gold, a sport from green and gold, of fine quality and appearance Cuban Queen, round, large, bright red, sweet and sugary Citron, for preserving

See Special Offers on third page of cover.

$\begin{array}{rrr}\text { Pkt. } & \text { Oz. } & \text { Lb. } \\ .05 & \$ 0.10 & \$ 0.80 \\ .05 & .10 & .80 \\ & & \\ .25 & 1.00 & \\ & & \\ .05 & .10 & .80 \\ .05 & .10 & .80 \\ & & \\ .05 & .10 & .80 \\ .05 & .10 & .80 \\ .05 & .10 & .80 \\ .05 & .10 & .80 \\ .05 & .10 & .80 \\ .05 & .10 & .80 \\ .10 & .40 & 4.00\end{array}$




\title{
MUSHROOM.
}

\author{
German, Champignon. - French, Champignon.-Spanish, Hongo.
} (Special offer No. 2 only applies to Mushroom Spawn.)

Mushrooms may be grown in cellars, out-houses, sheds,

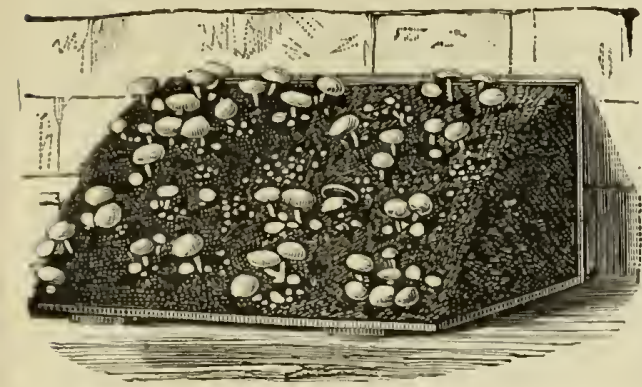
or under greenhouse benches. The amateur, however, is more likely to meet with success in cellars than elsewhere, as the cool moisture of the atmosphere and the uniform temperature are more congenial to the growth of this vegetable than that in structures above ground. The temperature should range between fifty-five and sixty degrees. Use a mixture of equal weights, fresh horse droppings and loam that has no manure in it. Before placing this mixture in the bed turn it over every day for a week so that it does not heat violently, and be careful to keep it under cover so that it cannot get wet. Then begin to make the bed by spreading thin layers of the mixture, and pound each firm, until you have in all a depth of eight to ten inches; leave it thus for a few days until the heat runs up to a hundred degrees or over and then declines to ninety degrees; when this point is reached it is readyfor spawning, which is done by making holes, three or four inches deep and twelve inches apart each way; into each hole put a piece of spawn about as large as a hen's egg and fill in the hole with compost. At the end of ten or twelve days the spawn will have run through the whole bed. There should then be spread over the entire surface about two inches of fresh loain. Over all place a few inches of straw. All that remains to be done is to keep the temperature as near to sixty degrees as possible; it should never be allowed to fall below forty degrees, or the crops will be both reduced and delayed. Ordinarily, if the conditions are right, mushrooms will appear in about six weeks and continue to come for about a month. In the event of the surface of the bed becoming very dry at any time sprinkle it freely with water at a temperature of about a hundred degrees. After the first crop has been taken off the bed, it should receive a dressing of fresh loam to a depth of half an ineh, thoroughly firmed, over the entire surface, and when dry a sprinkling with water as above recommended, and a second crop will soon be had. A brick of English spazun is sufficient for nine square feet of bed.

Mushroom Spawn, original English Milltrack, superior to all others

Mushroom Spawn, genuine French Virgin

Lb. $100 \mathrm{lbs}$

$.15 \$ 12.00$

$50 \quad 45.00$

\section{MUSTARD.}

\section{German, Senf. - French, Moutarde. - Spanish, Mostaza.}

Cultivated as a salad. The leaves are used like cress, when very young. Sow thickly in rows at different times from April to June, and cut when about two inches high; for use during winter, it may be sown at intervals in boxes, in the greenhouse, or in a frame. One ounce will sow forty feet of drill.

White London

Brown or Black, more pungent in flavor than white

Chinese, leaves twice the size of the ordinary white mustard, of a deeper green, flavor pleasantly sweet and pungent, and desirable as a salad

\begin{tabular}{lr} 
Oz. & \multicolumn{1}{c}{ Lb. } \\
.05 & $\$ 0.25$ \\
.05 & .25 \\
.15 & 1.00
\end{tabular}

\section{NASTURTIUM, or INDIAN CRESS.}

\section{German, Indianische Kresse.-- French, Capucine.-Spanish, Capuchina.}

Cultivated both for use and ornament; the seeds while young and succulent are picked and used as capers. The young leaves are also useful in salads. Its beautiful scarlet and orange colored flowers, which bloom freely all summer, add a charm to the garden. One onnce will sow forty feet of drill.

Tall, excellent for covering fences, trellis-work, etc.

Dwarf, good for borders

\section{OKRA, or GUMBO.}

\section{Gerinan, Essbarer. - French, Gumbo. - Spanish, 2uibombo.}

This vegetable is of the easiest culture, and grows freely, bearing abundantly in any ordinary garden soil. Sow early in May, in drills two inches deep, setting the plants from two to three feet apart. One ounce will sow forty feet of drill.

Improved Dwarf Green, early and productive

Tall White, about six feet high; pods eight to ten inches long; an ineh and a half thick at the stem, tapering to a point 


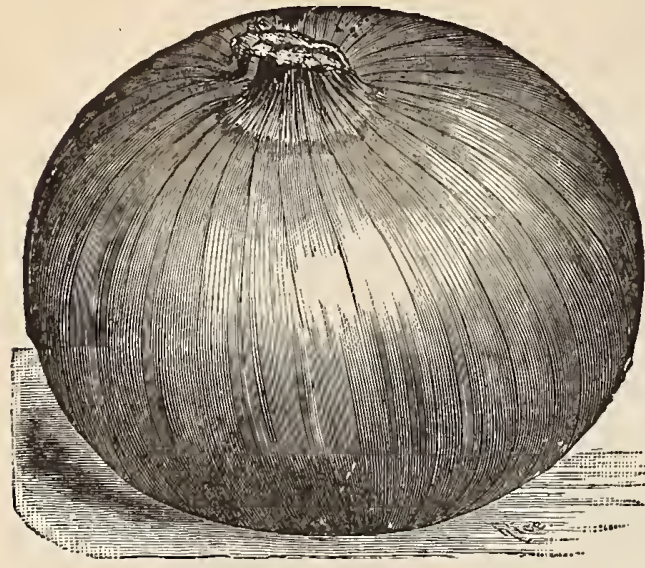

\section{ONION.}

German, Zweibel. - French, Ognon. - Spanish, Cebolla.

The Onion thrives best in rather strong, deep, loamy soil, which should be well enriched with old well-rotten manure or compost, or what is better, deeply trench, add manure the autumn previous to sowing, and lay upon ridges during the winter to soften. Sow the seed thinly in drills about one-quarter inch deep and one foot apart. To ensure quick and safe germination after sowing the seed, the drills should be trod along evenly with the foot, and then raked even, so that the hot, dry atmosphere may not dry up and destroy the sprouting seed. When three irches high thin to two inches apart. Hoe frequently to keep down weeds. In the seed rows where the hoe cannot be used, the soil should be stirred with the fingers, otherwise weeds will quickly grow up and choke the crop. One ounce of seed will sow one hundred feet drill; four pounds per acre.

The seED We OFFER, WITH THE EXCEPTION OF THE IMPORTED VARIETIES, IS EASTERN GROWN, AND CALCULATED TO GIVE MORE SATISFACTORY RESULTS THAN WESTERN-GROWN SEED.

Yellow Globe Danvers, grown from specially selected bulbs .

Yellow Globe Danvers, good, but not quite as good as the foregoing

Large Red Wethersfield, deep-red color, immense yielder and excellent keeper .

Red Globe, a fine. globe-shaped onion of superior quality

Extra Early Red, flat in shape and fully two weeks earlier than the Wethersfield .

White Portugal, early, mildly flavored, and excellent

New Queen, a small white variety grown extensively in the Soutl

Giant Rocca, beautiful globe-shaped, light-red onion, and mildly flavored :

White Italian Tripoli, grows to an immense size, flat in shape, very mild in flavor

Red Italian Tripoli, same as the White, except in color

\section{ONION SETS.}

\section{(Prices Variable.)}

Special Offer No. 2 only applies to Onion Sets.

The sets should be planted out as early in spring as the ground is dry enough to work; plant them in rows one foot apart, with sets three or four inches apart. When raised from sets the onions can be used in the green state in June, or they will be ripened off by July.

Top or Button Onions . - . - . $30 \quad \$ I .50$ Onion Sets, White .

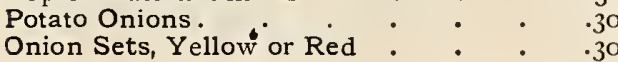

\section{PARSNIP.}

Pkt. Oz. Lb.

$\begin{array}{lll}.10 & .30 & \$ 3.00\end{array}$

$\begin{array}{lll}.05 & .25 & 2.50\end{array}$

$\begin{array}{lll}.05 & .25 & 2.50\end{array}$

$\begin{array}{lll}.05 & .25 & 2.50\end{array}$

$\begin{array}{lll}.05 & .25 & 2.50\end{array}$

$\begin{array}{lll}.05 & .35 & 3.50\end{array}$

$\begin{array}{lll}.05 & .25 & 2.50\end{array}$

$\begin{array}{lll}.05 & .25 & 2.50\end{array}$

$\begin{array}{lll}.05 & .25 & 2.50\end{array}$

$.05 \quad .25 \quad 2.5 \mathrm{C}$

\section{German, Pastinake. - French, Panais. - Spanish, Pastinaca.}

Sow thick in April, in rows twelve inches apart and one inch deep, in a rich, deep soil, well manured the previous fall, or with fine manure early in March. When the plants are two or three inches high, thin out to five or six inches apart in the rows. Unlike carrots they are improved by frost, and it is usual to take up in the fall a certain quantity for winter use, leaving the rest in the ground until spring, to be dug up as required. One ounce for one hundred feet of drill; five pounds to an acre.

Long Smooth, the best for general use.

The Student, a fine-flavored variety

\section{PARSLEY.}

German, Petersilie. - French, Persit. - Spanish, Perejil.

Soak the seeds a few hours in tepid water, and sow early in the spring in drills one foot apart; thin out the plants to three or four inches apart; a single row forms a very good edging for beds or walks. The seed germinates very slowly, and sometimes two ur three weeks will elapse before the plants make their appearance. One ounce to one hundred and fifty feet of drill.

New Fern-ieaved, most exquisite in form and coloring

Extra Moss Curled, leaves beautifully curled, extra fine for garnishing

Hamburg or TurnipRooted, roots used for flavoring soups.

$\begin{array}{ccc}\text { Pkt. } & \text { Oz. } & \text { Lb. } \\ .05 & .15 & \$ 1.25 \\ & & \\ .05 & .15 & \mathbf{1} .25 \\ .05 & .15 & \mathbf{1} .25\end{array}$

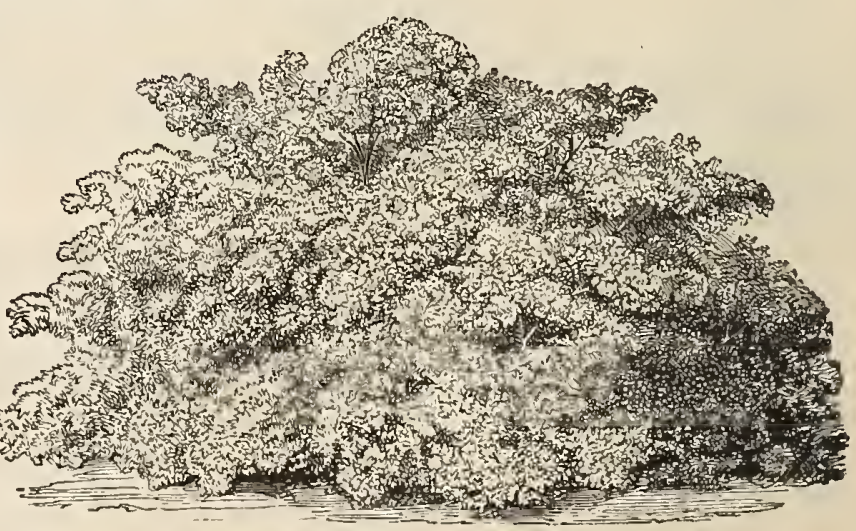

See Special Offers on third page of cover. 


\section{PEAS.}

German, Erbse. - French, Pois. - Spanish, Chicaros.

Peas come earliest to maturity in light, rich soils, but for a general crop a deep loam or moderately heavy 6oil is better. For early crops decomposed leaves or leaf mould should be used; if the soil is very poor stronger manure may be applied. The first sowing will be earlier if covered only one inch deep; those following should be covered two to six inclies deep, the deep planting preventing mildew and prolonging the season. Fresh manure, and wet, mucky soil should be avoided, as they cause the vines to grow too rank and tall. All wrinkled Peas are superior to, more delicate in flavor, and remain longer in season than the smooth sorts, but should not be sown until the ground becomes warm, for, as in sugar-corn, the wrinkled appearance indicates the greate amount of saccharine matter.

\section{EXTRA EARLY SORTS.}

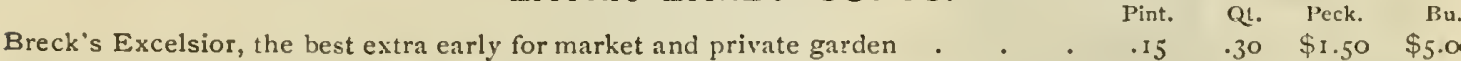
P. \& W. Maud S., a valuable extra early variety _. . . . . . . . . . . . . $\quad .30 \quad 150 \quad 5.00$ Alaska, a smooth, blue, prolific, sweet extra early variety . . . . . . . . . . $30 \quad 1.50 \quad 5.00$ Improved Dan'l O'Rourke, a standard extra early variety

Early Dexter, one of the best round white-seeded varieties

Kentish Invicta, resembles Pint. Q. Peck. Bu. $\begin{array}{lllll}\text { Alaska, but a little later. } & .15 & .25 & \$ 1.25 & \$ 4.50\end{array}$

Tom Thumb, very early, excellent quality, grows only about nine irrches high.

Bliss' American Wonder, earliest wrinkied sort.

Carter's Premium Gem, a $\mathrm{d} w a r f$ prolific green wrinkled early variety . McLean's Little Gem, a variety similar to the pre.

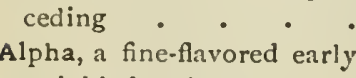

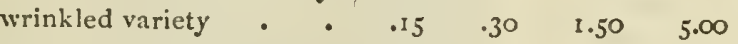

\section{SECOND EARLY SORTS.}

Bliss' Abundance, strong vines of medium height that bear an enormous number of well-filled pods, quality superior . .

Boston Wrinkled, superior to any other second early solt . . . McLean's Advancer r, a dwarf green wrinkled mar. row of fine flavor

Bliss' Everbearing, a most desirable main $\begin{array}{ccc}1.25 & 4.50\end{array}$

$\begin{array}{llll}.15 & .25 & 1.50 & 5.00 \\ .15 & .30 & 1.50 & 5.00\end{array}$

$\begin{array}{llll}.15 & .30 & 1.50 & 5.00 \\ .20 & .40 & 2.25 & 8.00\end{array}$

$\begin{array}{llll}.15 & .30 \quad 1.75 \quad 6.00\end{array}$

$.15 \quad .30 \quad 1.75 \quad 6.00$

(n)

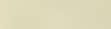

6.00

6.00

\section{GENERAL CROP.}

Champion of England, the standard late variety, sweet and productive

Yorkshire Hero, a wrinkied marrow of extra fine quality.

Carter's Telephone, a vigorous grower, extra large well-filled pods

Stratagem, a sport that usually produces stalky vines covered with fuli pods of extra size.

Shropshire Hero, after the style of Yorkshire Hero, but more desirable .

Pride of the Market, an enormously productive wrinkled marrow of good quality

Profusion, a productive, large-podded sort of good quality

Dwarf White Marrow, an old-fashioned yet popular variety

Blackeye Marrow, an excellent old-fashioned sort

\section{EDIBLE PODDED PEAS.}

Early Dwarf Wrinkled Sugar, a French variety, early and of good quality . Tall Gray Sugar, can be used either shelled or cooked in the pods 


\section{PEPPER.}

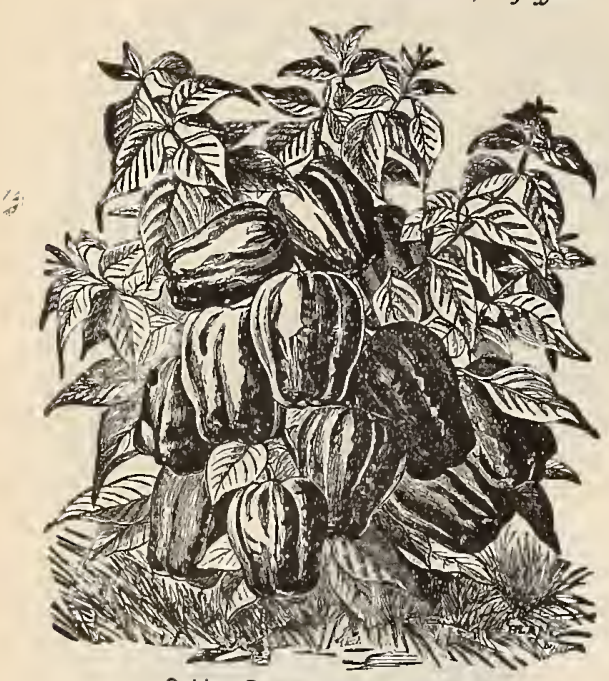

Golden Dawn Mango Pepper.

German, Pfeffer. - French, Piement. - Spanish, Pimiento.

Plant in hot-beds in March, and transplant into the open ground the latter part of May, in rows about twenty inches apart and eight inches apart in the row. Repeated hoeings promote their growth.

One ounce of seed will produce about 2,ooo plants.

LARGE BELL, or BULL NOSE, fruit large; an early sweet variety . . .

Cayenne, Long Red; the pods of this variety are from three to four inches in length, cone-shaped, and coral red when ripe .

Squash, or Tomato Shaped, the kind most generally grown for pickling; an excellent sort

SWEET MOUNTAIN, Or MAMMOTH, similar in shape to the Large Bell, but of much larger size.

Red Cherry, fruit round; very productive and ornamental
Pkt. Oz, Ib.

$.05 \quad .30 \$ 3.50$

$.05 \quad .30 \quad 3.50$

$.05 \quad .30 \quad 3.50$

$.05 \quad \cdot 30 \quad 3.50$

$.05 \quad .30 \quad 3.50$

\section{PUMPKIN.}

German, Kurbis. - French, Courge. - Spanish, Calabaza.

The Pumpkin is now little used except for agricultural purposes, the squashes being so much sweeter and drier and finer grained for the kitchen. The farmer, however, finds the Pumpkin a serviceable addition to his feed. The most common and least troublesome method of cultivation is to plant them with corn, two or three seeds in each hill.

Sweet Sugar, round, not large, but very sweet, and an excellent table variety .

Pkt. Oz. Lb.

$\cdot \quad . \quad .05 \quad .10 \quad \$ 0.60$

Mammoth, grows to an immense size, often weighing over one hundred pounds $\quad . \quad$. $\quad . \quad .10 \quad .30 \quad 3.00$

Connecticut Field, very productive; largely grown for feeding stock. Per bushel, $\$ 4.00 \quad$ • $\quad .05 \quad .10 \quad .25$

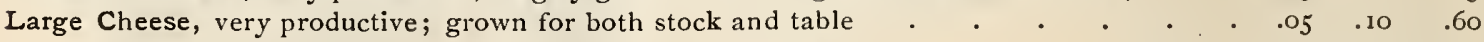

\section{POTATOES.}

\section{PRICES SUBJECT TO MARKET CHANGES.}

Special prices on large quantities quoted on application. Special Offer No. 2 only applies to Potatoes.

Of the many varieties of Potatoes that claim public favor, we have selected only a few, and these the best in cultivation. We aim to include in our list only those sorts which we have found by actual test are worthy of cultivation. Orders will be booked as received, and shipped in rotation, after danger of freezing is over; and as Potatoes are of perishable character, we assume no responsibility for dam. ages incurred in transit, but we will, of course, exercise the greatest care to guard against sudden changes in the temperature.

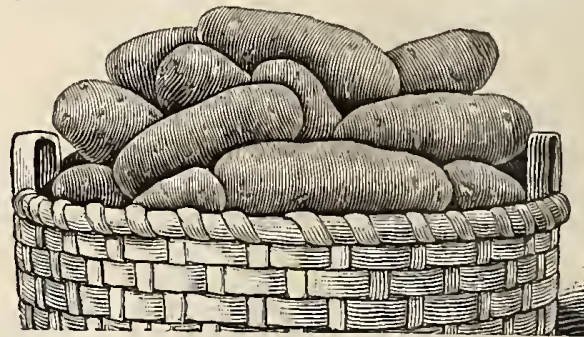

Early Northern, a seedling from Early Rose, which it resembles; productive

New Queen, true Northern Maine grown, good keeper, very early, excellent quality

Bliss Triumph, well-known early sort, of superior quality and excellent flavor .

Ohio Junior, extra early sort, good keeper, very productive, of fine quality

Polaris, a sport from Early Rose, white skinned, fine grain, very mealy

Clark's No. I, well-known sort, fine flavor and exceedingly productive -.75

P. and W. Victory, a handsome variety, resembling Clark's No. 1, but earlier . . . 60

Pearl of Savoy, very early, large, oblong tubers, productive, and of superior quality . .60

Beauty of Hebron, a standard sort, pure white skin and flesh; the best for general use.$\quad{ }_{50}^{\circ}$

Houlton Early Rose, so well known it needs no description; our stock is true and unmixed,

Dakota Red, produces freely large tubers, skin rough, and netted eyes quite deeply set

See Special Offers on third page of cover.

Peck. Bush. Bbl.

$.75 \$ 2.00 \$ 4.00$

$.60 \quad$ I. 75

. 75.50

$2.00 \quad 4.00$

$2.00 \quad 4.00$

$2.00 \quad 4.00$

I.75 3.50

I. 75350

I.75 $3.5^{\circ}$

$1.50 \quad 3.25$

1. $50 \quad 3.25$

$\begin{array}{lll}.50 & \text { I. } 50 \quad 3.25\end{array}$ 


\section{RHUBARB.}

\section{German, Rhabarber. - French, Rhubarbe. - Spanish, Ruibarbo Bastardo. \\ (For price of Rhubarb Roots, see Vegetable Plants.)}

Sow early in the spring, in drills a font apart, thinning out to about the same distance apart in the rows when a few inches high. In fall, or the following spring, transplant into deep, rich soil about three feet apart each way. If propagated by dividing the roots, it may be done either in fall or spring, planting it at the same distance apart as given above.

Linnæus, early, large, and tender

Victoria, very large, later than Linneus

\section{RADISH.}

German, Rettig, Radieschen. - French, Radis, Rave, Petit Rave. - Spanish, Rábano.

Radishes require a light, rich, sandy loam; heavy or clayey soils not only delay their maturity, but produce crops much inferior, both in appearance and especially in flavor. For a constant supply, sow from the middle of March until September, at intervals of two or three weeks. For an early supply they may be sown in a hot-bed in February. For winter Radishes, sow the seed about beginning of July, and keep the roots during winter in a cool cellar, covered with earth. They should be placed in cold water an hour or so before using.

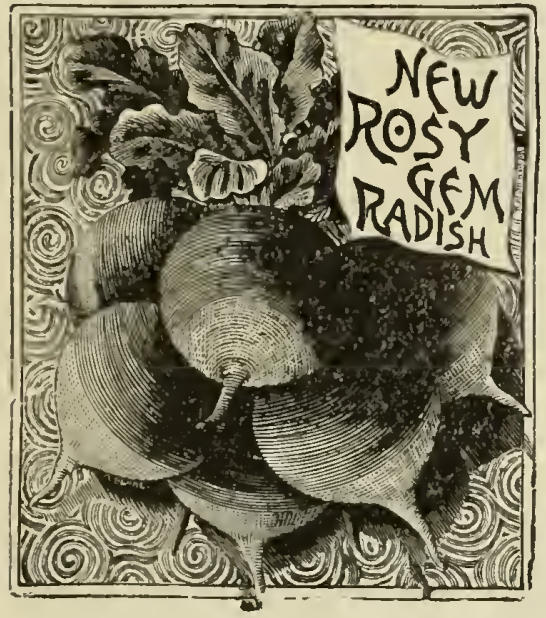
I oz. of seed will sow soo feet drill; so lbs. per acre.

Long Scarlet Short-Top, bright scarlet, crisp

French Breakfast, a variety of quick growth

The Startle, a half.long variety, fine for forcing,

Olive-Spades Scarlet, an early sort

Rosy Gem, globe-shaped, upper portion scarlet, shading into white at the tip

White Tipped Scarlet Turnip, an early variety of medium size, crisp and tender

Scarlet Turnip, one of the best for summer use .

White Turnip, excellent for summer use

Rose China Winter, bright rose color, grows to a large size, quality excellent .

Long Black Winter, an exceedingly fine winter variety

Round Black Winter, like the preceding, except in shape

\section{SALSIFY, or OYSTER PLANT.}

German, Boksbart. - French, Salsifis. - Spanish, Ostra Vegetal.

The demand for Salsify is increasing from year to year, as its delicious qualities are becoming known. It

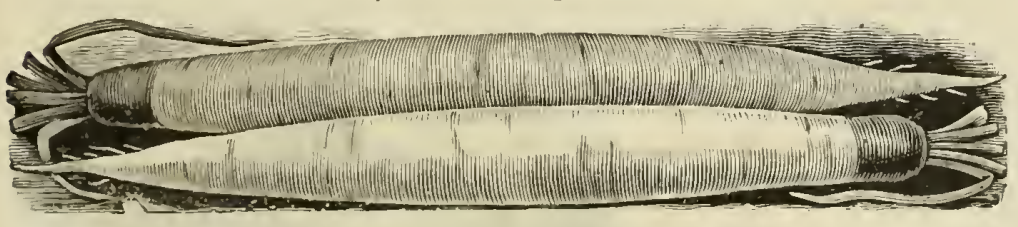

Breck's Improved, roots of medium size, white and smooth Mammoth Sandwich Island, twice as large as the preceding, is used stewed, boiled, or fried, and sometimes as a salad sliced raw in vinegar with salt and pepper. When cooked it has anoyster flavor, and is commonly called "vegetable oyster." Cultivate and start same as Parsnip. One ounce will sow fifty feet of drill.

$\begin{array}{llr}\text { Pkt. } & \text { Oz. } & \text { Lb. } \\ .05 & .15 & \$ 1.50 \\ .05 & .15 & 1.56\end{array}$

\section{SPINACH.}

German, Spinat. - French, Epinard. - Spanish, Espinaca.

Spinach likes a rich soil, and should be sown for a main crop in August or September. When cold weather sets in, it should be protected from frost by covering it with straw and brush. For summer use sow at intervals of two or three weeks from April to August. One ounce will sow fifty feet of drill; twelve pounds per acre.

Round Thick Leaf, one of the best.

Long Standing, does not readily run to seed.

Savoy Leaf, an extra good "carrier"

Prickly or Winter. hardy .

New Zealand (Tetragonia expansa), a distinct spreading plant, producing an abundant supply of greens all suminer; should be started in a hotbed, and transplanted when the ground is warm; set three feet apart each way

\begin{tabular}{llr} 
Pkt. & Oz. & \multicolumn{1}{c}{ L.b. } \\
.05 & .10 & $\$ 0.30$ \\
.05 & .10 & .30 \\
.05 & .10 & .30 \\
.05 & .10 & .30
\end{tabular}

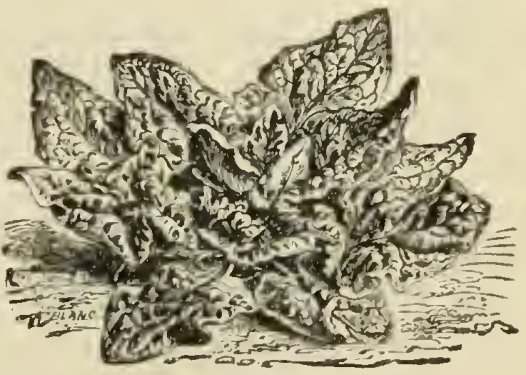

$.05 \quad .15 \quad 1.00$

See Special Offers on third page of cover. 


\section{SQUASH.}

German, Kurbiss. - French, Courge. - Spanish, Calabaza Tontanera.

As ali Squash are somewhat tender, they should not be planted out until danger from frost is past. The will grow on almost any soil, but a warm, mellow one that has been well manured suits them best. The hills for bush varieties should be about six feet apart; for running sorts, eight to ten feet. Thin out to two plants to a hill, and in the early stages of growth keep well sprinkled with plaster dust. Bush varieties, one ounce to fifty hills; running varieties, one ounce to twenty hills; four pounds per acre.

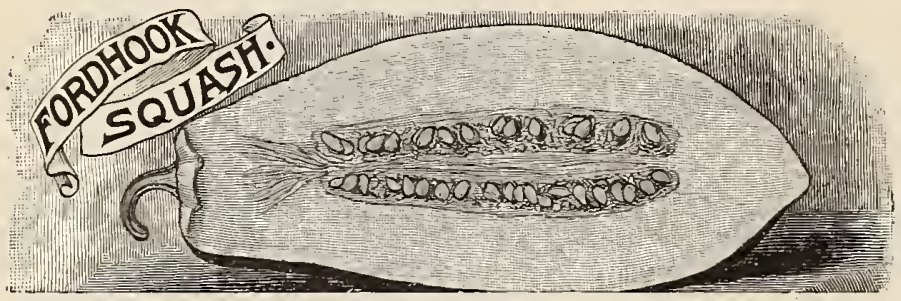

White Bush Scalloped,

Pkt. Oz. Lb. the best for very early use

Golden Summer Crook neck, long in shape, bright-yellow color, an excellent summer sort,

Early Prolific Marrow, earlier and more prolific than the Boston Marrow

Fordhook, a small, extra quality, cream-colored squash, that keeps well till spring .

Boston Marrow, a good fall and winter variety, follows in earliness the summer sorts

Hubbard, a standard winter squash, meat dry, and fine flavored .

Marblehead, remarkable for its combination of sweetness, dryness, and delicious flavor

Essex Hybrid, a cross between Turban and Hubbard, an excellent keeper

American Turban, very fine grained, dry, rich, and sweet .

Bay State, style of Essex Hybrid, color blue, fine dry, sweet flesh

Wirter Crookneck, an old standard variety, hardy, and a good keeper

Canada Crookneck, the best of the winter Crooknecks for table use; small, but productive

\section{SUNFLOWER.}

Large Russian

TOBACCO.

Connecticut Seed-Leaf, best adapted to the climate of the Northern and Middle States

$.05 .10 \$ 0.75$

$.05 \quad .10 \quad .75$

$.05 \quad .10 \quad .75$

$.05 \quad .10 \quad 1.00$

$.05 \quad .10 \quad .75$

$.05 \quad .10 \quad .75$

$.05 \quad .10 \quad .75$

$.05 \quad .10 \quad .75$

$.05 \quad .10 \quad .75$

$.05 .10 \quad .75$

$.05 \quad .10 \quad .75$

$.05 \quad .10 \quad .75$

Pt. Qt. Bush. . $10 \quad .15 \$ 3.00$

Pkt. Oz. I.b. $.10 \quad .30 \$ 3.00$

\section{TOMATO.}

\section{German, Liebesapfel. - French, Tomate. - Spanish, Tomate. \\ (For Tomato Plants, see Vegetable Plants.)}

The seed should be sown in a hot-bed about the first week in March, in drills five inches apart and half an inch deep. When the plants are about two inches high, they should be set out about four or five inches apart in another hot-bed. About the middle of May the plants may be set in the open ground; they are planted for early crops on light, sandy soil, at a distance of three feet apart, in hills in which a good shovelful of rotten manure has been mixed. On heavy soils, which are not suited for an early crop, they should be planted four feet apart. Water freely at the time of transplanting, and shelter from the sun for a few days until the plants are established. One ounce will produce about 2,00o plants.

Breck's Belmont, the best for either forcing or out-door culture. The bright-scarlet fruit is borne in clusters of four or five. It is finely flavored, has very few seeds, no core, Pkt. Oz. Lb. and remains firm a long time when ripe. . . 10 .40 $\$ 4.00$

Acme, very early and productive, medium size, dark-red fruit

Dwarf Champion, of dwarf and strong habit, fruit fine color, with few seeds

Canada Victor, one of the earliest, of medium size, very symmetrical in form . .

Lorillard, especially adapted for culture under glass

$.05 \quad .30 \quad 3.00$

$.05 \quad .30 \quad 3.00$

$.05 \quad 30 \quad 3.00$

$\begin{array}{lll}.05 & .30 \quad 3.00\end{array}$

ivingston's Beauty, an early variety, growing in clusters of four or five, glossy crimson in color

Livingston's Favorite, perfect in shape; ripens evenly and quite early. It is noted for its good shipping qualities

$.05 \quad .30 \quad 3.00$

$\begin{array}{lll}.05 & .30 \quad 3.00\end{array}$

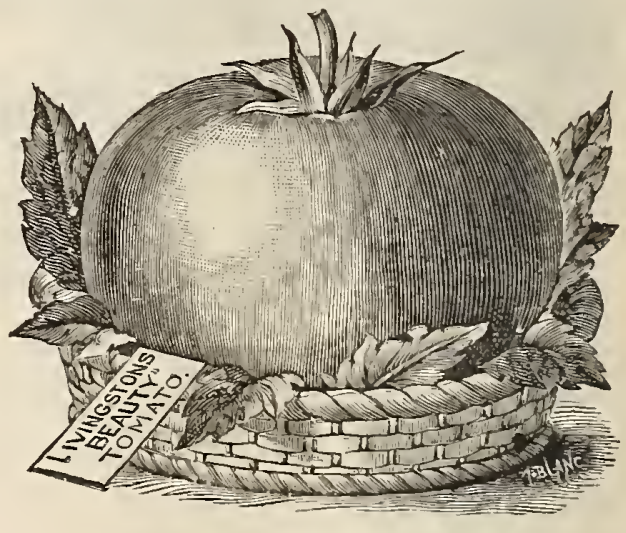

Livingston's Perfection, large and early, blood red, perfectly smooth, thick meat, few seeds, Paragon, medium size, color dark-red, ripens evenly, very solid, largely used for canning. Peach, resembles a peach in size, shape, and color; fine for preserves

Red Cherry, a small early variety, size and shape of a cherry, used for pickling

Yellow Cherry, similar to preceding, except in color.

Strawberry, or Winter Cherry (Plyysalis Alkekengi). The fruit grows in a husk, and will keep all winter. It has a pleasant strawberry-like flavor and is esteemed by many for preserving, See Special Offers on third page of cover.

$\begin{array}{llr}\text { Pkt. } & \text { Oz. } & \text { Lb. } \\ .05 & .30 & \$ 3.00 \\ .05 & .25 & 2.50 \\ .05 & .30 & 3.00 \\ .05 & .30 & 3.00 \\ .05 & .30 & 3.00 \\ .05 & .30 & 3.00\end{array}$




\section{TURNIP.}

German, Steckrube. - French, Nazet. - Spanish, Nabo Comun.

Turnips may be sown at all seasons from April to August in our climate, although those will be the bes: which are sown very early in spring for summer crop, and early in August for a fall and winter crop. A light soil well manured the previous year is the best; no manure should be applied at the time of sowing, unless it be well-decomposed compost, or the roots would be liable to be bad-flavored. The ground should be dug and ploughed deep and made mellow and fine. Sow the seed of the flat sorts broadcast, and rake in evenly. After they are well up, thin to six or eight inches apart, and keep them clear from weeds. The Ruta Baga sorts should be sown in drills fifteen inches apart, and for winter use may be sown from the twentieth of June to the middle of July, on land that has been well manured for other crops in spring; thin out as for the early crop. One ounce will sow 5 so-feet drill. Two pounds will sow one acre in drills. One pound will sow one acre broadcast.

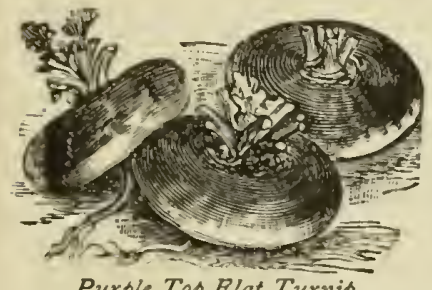

Purple Top Flat Turnip.
Purple-Top Milan, th earliest of the flat Redtop Turnips, sinall strapped leaves, white, sweet, tender flesh

Red top Strap Leaf, the best of the flat Turnips. Equally valuable for early or late crops.

White-Top Strap Leaf, similar to the preceding, but not so popular

White Egg, a handsome egg-shaped white variety; grows large

White Norfolk, one of the best late varieties for stock.

Long White or Cow Horn, flesh white, fine graded and sweet, and of excellent quality.

Purple-Top White Globe, a round handsome turnip of superior quality, either for the table or stock

lellow Stone or Globe, of medium size, excellent flavor, and a good keeper; flesh yellow, Golden Ball, a small, golden-yellow flesh variety, unsurpassed for table use

lellow Aberdeen, very hardy and productive; good for stock and table; keeps well. .

$\begin{array}{lll}\text { Pkt. } & \text { Oz. } & \text { Lb. } \\ .05 & .10 & .50 \\ .05 & .10 & .50 \\ .05 & .10 & .50 \\ .05 & .10 & .50 \\ .05 & .10 & .50 \\ .05 & .10 & .50 \\ .05 & .10 & .50 \\ .05 & .10 & .50 \\ .05 & .10 & .50 \\ .05 & .10 & .50\end{array}$

\section{RUTA BAGA, or SWEDISH TURNIP.}

Improved American, flesh yellow, solid, sweet, and fine flavor

Skirving's Purple Top, large-yellow, firm flesh, sweet, and a good keeper

Shamrock, a globe-shaped, very hardy, fine-grained, Pkt. Oz. Lb.

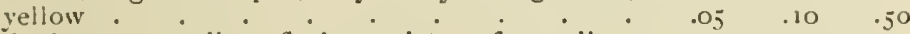

St. Andrews, a yellow flesh variety of excellent quality.

Sweet German, flesh pure white, very solid, sweet, mild, well flavored

White French, an excellent sort for table or stock. Flesh firm, white, and solid; a popular market variety

Budlong Swede, a choice strain of white Swede, said to be earlier and of better form than other sorts

$.05 \quad .10 \quad .50$

$.05 \quad .10 \quad .60$

$.05 \quad .10 \quad .60$

$.05 \quad .10 \quad .60$

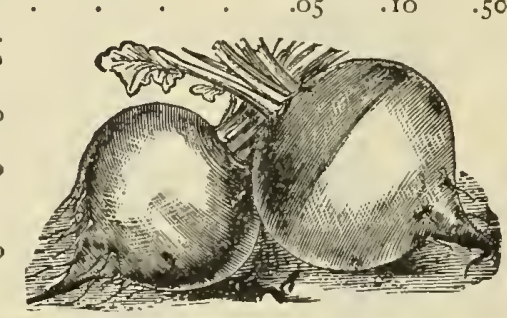

Purple Top Ruta Baga Turnip.

SWEET, POT, and MEDICINAL HERBS.

\begin{tabular}{|c|c|c|c|c|c|c|c|c|c|c|c|c|c|c|c|c|c|c|c|}
\hline Anise & & • & & $\begin{array}{r}\text { Pkt. } \\
.05\end{array}$ & $\begin{array}{c}\text { Oz. } \\
\text { \$o.15 }\end{array}$ & Coriander & & - & & & & $\begin{array}{l}\text { Pkt. } \\
.05\end{array}$ & $\begin{array}{c}\text { Oz. } \\
\text { \$o. } 15\end{array}$ & Rosemary. & & • & - & $\begin{array}{l}\text { Pkt. } \\
\text {. Io }\end{array}$ & $\begin{array}{r}\mathrm{Oz} \\
\$ 0.50\end{array}$ \\
\hline Balm & . & e & & . .10 & .40 & Dill . . & . & . & . & - & - & .05 & .15 & Rue. . & - & & • & .10 & .30 \\
\hline Basil Sw & reet & - & - & .10 & .20 & Fennel. & & . & - & - & - & .05 & .15 & Sage. . & & . & . & .05 & \\
\hline Borage & . . & - & . & .05 & .20 & Hop Seed & & - & . & - & . & .25 & 2.00 & Savory, Sumn & mer & & . & .05 & .2 \\
\hline Caraway & y & - & - & .05 & . Io & Horehound & & - & - & . & - & .10 & .40 & Sorrel, Broad- & & ved & . & .05 & .2 \\
\hline Catnip & & • & - & .10 & .50 & Hyssop. & - & - & - & - & - & .10 & 40 & Thyine, Broad & d. lea & aved & . & .05 & \\
\hline vil, & Curl & . & . & .05 & .20 & Lavender & - & - & - & . & - & .05 & .20 & Winter Savory & $y \quad \cdot$ & • . $\cdot$ & . & .10 & \\
\hline hicory & . & . & . & .05 & .10 & Marjoram & & & & . & . & .05 & .25 & Wormwood & & & & .05 & \\
\hline
\end{tabular}

\section{FRUIT-TREE SEEDS.}

\begin{tabular}{|c|c|c|c|c|c|c|c|c|c|c|c|c|}
\hline App & $\begin{array}{l}\text { Pkt. } \\
\$ 0.05\end{array}$ & $\begin{array}{l}\mathrm{O} z . \\
\text { \$o.10 }\end{array}$ & $\begin{array}{r}\text { Lb. } \\
\text { \$o } 50\end{array}$ & Currant. & $\begin{array}{l}\text { Pkt. } \\
\text { \$o } 10\end{array}$ & $\begin{array}{l}\text { Oz. } \\
\text { \$o. }\end{array}$ & $\$$ T.b. & Quince. . & & $\begin{array}{l}\text { Pkt. } \\
\$ 0.10\end{array}$ & $\begin{array}{r}\mathrm{Oz} . \\
\$ 0.25\end{array}$ & $\begin{array}{l}\text { Lb. } \\
\$ 2.50\end{array}$ \\
\hline ot Pits & .05 & .10 & .50 & Gooseberry & .15 & 1.00 & 10.00 & Raspberry . & & .15 & .25 & 7.00 \\
\hline Blackberry & .15 & 1.00 & 10.00 & $\begin{array}{l}\text { Peach, per b } \\
\text { Pear }\end{array}$ & $\begin{array}{l}1 ., \$ 2.50 \\
. \quad .10\end{array}$ & .25 & & Strawberry & - & .15 & .So & \\
\hline
\end{tabular}

\section{BIRD SEED, ETC.}

Canary, Sicily, per quart .

Hemp, Russian,

Hemp, American, “

Rape, English,

Rape, German,

Unhulled Rice, \$o. 5 Flax Seed, per quart

. 5 Millet, German,

.I5 Maw, or Poppy Seed, per lb.,

.15 Cuttle-fish Bone, per lb.

-15 Mocking-Bird Food, I-lb. bot-

.15 tles, each . . . . .
\$0.25 Mocking. Bird Food, in bulk,

.10 per pound . . . . . \$o.25

.25 Song Restorer, per bottle . $\quad .25$

.40 Parrot Food, per quart . : .20

Special offer No. 2 only applies to Fruit-Tree and Bird Seeds.

See Special Offers on third page of Cover. 


\section{VEGETABLE PLANTS AND ROOTS.}

All especially grown for our trade from choicest strains of seed.

\section{ASPARAGUS ROOTS.}

Colossal, two year old roots

The Hub, two year old roots

Palmetto

\section{CABBAGE PLANTS}

From hot-beds, ready about first week in April.

Early Jersey Wakefield

Henderson's Summer

Stone Mason

Fottler's Brunswick.

For Winter Crop. Ready July ist.

Savoy American Improved

Fottler's Brunswick

Stone Mason

\section{CAULIFLOWER.}

Breck's White Bouquet Snowball

\section{CELERY PLANTS.}

Boston Market

Golden Self-Blanching

Giant Pascal

White Plume

Chives, used for flavoring soups, etc., each .15; dozen, $\$ 1.25$.

\section{EGG PLANTS}

New York Improved

Black Pekin

$$
\begin{array}{rr}
100 & 1000 \\
\$ 1.00 & \$ 7.00 \\
1.50 & 12.00 \\
1.50 & 12.00
\end{array}
$$

$$
\begin{array}{rr}
100 & 1000 \\
\$ 1.02 & \$ 8.00 \\
1.00 & 8.00 \\
1.00 & 8.00 \\
1.00 & 8.00 \\
& \\
.50 & 4.00 \\
.50 & 4.00 \\
.50 & 4.00
\end{array}
$$

$100 \quad 1000$

$\$ 1.50$ \$1 2.00

$1.50 \quad 12.00$

$\begin{array}{rr}\text { 100 } & 1000 \\ \$ 1.00 & \$ 8.00 \\ 1.00 & 8.00 \\ 1.00 & 8.00 \\ \text { I.00 } & 8.00 \\ \text {.1 } 5 ; \text { dozen, }\end{array}$

$$
\begin{array}{lr}
\text { Doz. } \\
\$ 1.00 & \$ 6.00
\end{array}
$$$$
\text { I.00 } 6.00
$$

TARRAGON PLANTS.

Each .

Per Dozen

$\$ 0.30$

HORSE-RADISH SETS.

Per dozen, 25 cents; per I0o, 60 cents; per $1000, \$ 5.00$

\section{LETTUCE PLANTS}

\section{Boston Market Head}

Early Curled Simpson

PEPPER PLANTS.

Large Bell or Bull Nose. Per doz., \$1.00; per 100,
\$6.00. RHUBARB ROOTS.

Each
Per dozen

SWEET POTATO PLANTS.

Nansemond

$100 \quad 1000$ TOMATO PLANTS.

Breck's Belmont

Acme .

Paragon

Dwarf Champion

Livingston's Perfection

\section{GRAINS, ETC.}

(Prices subject to market changes.)

All our Grains are selected expressly for Seed, and are strictly pure and true.

\section{BUCKWHEAT.}

Japanese, early, immense cropper, and extra fine quality

Silver Hull, an improved variety

Common, yields an average of 20 to 30 bushels per acre

\section{BARLEY.}

Two-Rowed

Four-Rowed

OATS.

American Triumph, attains a growth of six feet, yet the straw is so strong and firm that it heads up well.

Per Bush.
$\$ 1.75$
1.50
1.25
Per Bush.
$\$ 1.25$
1.25

$\$ 1.00$

OATS

Welcome, a very heavy oat

Per Bush.

$\$ 1 . \infty$

White Bedford, the standard market sort . $\quad .80$

Black Tartarian, the most prolific and distinct variety of black oats grown. Will not lodge even on meadow land

2.00

\section{RYE.}

To avoid disappointment to our customers, we offer only Rye saved from crops we have seen growing.

\section{Spring
Winter, this is the ordinary variety sown in
the Fall} Per Bush.

I. 25

\section{SPRING WHEAT.}

Saskatchewan Fife, the best number one hard amber yet introduced. Unequalled for yield, earliness, and vigor

White Russian, a beardless white chaff wheat, with amber-colored grain

Lost Nation, a popular bald wheat

\section{WINTER WHEAT.}

Mediterranean Hybrid, heads broad, medium length, and full of large, plump, heavy, red grains

Martin Amber, heads beardless, four to seven inches long, good sized, full of plump grains of clear amber color

Clawson White, a well-known and favorite sort

\section{SPRING VETCHES, or TARES.}

Spring Vetches, extensively fed in England to Milch Cows. Sow broadcast at the rate of two to three bushels per acre

\section{PEAS}

Canada Field, a quick maturing valuable crop, either for soiling or green fodder. Sow 2 to 3 bushels per acre Special offer No. 2 only applies to articles on this page. See third page of cover.

Per Bush. 


\section{GRASSES.}

"And he gave it for his opinion that whoever would make two eurs of corn or two blades of grass to grone upon a spot of ground where only one grew before would deserve beller of mankind, and do more essential service to his country, than the whole race of politicians put together." - SwiFT.

$\left(\mathbb{U}^{\mathrm{E}}\right.$

E desire to call special attention to the following list of Agricultural Grasses, which will, we think, be found very comprehensive, both as to varieties and descriptions. We are devoting a great deal of time to this most important subject, and the department has aiready become an extensive one with us.

Having learned by experience that the so-called imported grasses which are offered by those making a specialty of them in this country are very far from reliable, both as regards purity and quality, we have found it necessary to import all our seeds of this character direct. We have accordingly made arrangements for our stocks with one of the most prominent growers of Agricultural Grasses on the continent, who, by virtue of many years' experience in growing seeds of this peculiar character, has become the recognized headquarters for same. This will enable us to furnish our customers with the very best, and that which we know to be free from all adulteration.

It seems almost unaccountable that at this day, when the different branches of practical agriculture are seemingly so thoroughly understood, that our American farmers should apparently ignore the importance of sowing upon their fields only those kinds of grasses which are adapled to the soil and climale, and which will produce in the shortest length of time a luxuriant crop of the desired character. The list of grasses now in use by most of our farmers can be counted on the fingers of one hand, which showing is indeed a small one, when we take into consideration the many species, valuable because of their respective merits, which should be in constant demand for the various soils and climates of America.

We invite special attention to our "Mixtures" for Permanent Pastures and Mowing Lands, which follow our descriptions. We have endeavored to bring into prominence a few important facts under the head of Mixtures, which, we think, cannot fail to be of interest to any one who is concerned in the laying down of profitable pastures, or who desires to obtain large crops of hay of choice quality from their fields.

TIMOTHY (Herd's Grass or Catstail), (Phleum pratense). Root fibrous on moist soils; on dry soils often bulbous; perennial; flowers in June and July. While this grass is commonly known as Timothy, it is frequently called Herds Grass, as this is the name under which it was originally cultivated. It is, without doubt, a most valuable grass for hay, especially in the North. It thrives best on moist, loamy soils of medium tenacity. Grows very readily and yields large crops on favorable soils. Should be cut just when the blossom falls. The hay is of best quality, yielding, under favorable circumstances, three or four tons per acre.

ORCHARD GRASS (Dactylis glomerata). Root fibrous; perennial; flowers in June and July. This is one of the most valuable and widely known of all the pasture grasses. Its rapidity of growth, the luxuriance of its aftermath, and its power of enduring the cropping of cattle, all commend it highly to farmers. Thrives well on light soils, and as its roots penetrate to a considerable depth, where the subsoil is favorable it withstands droughts better than most species on dry sandy soils. It is very valuable to be used in a mixture with Timothy and Clover, and produces splendid crops of hay. This grass is sometimes condemned because of its coarse growth, which is only apparent when in a neglected

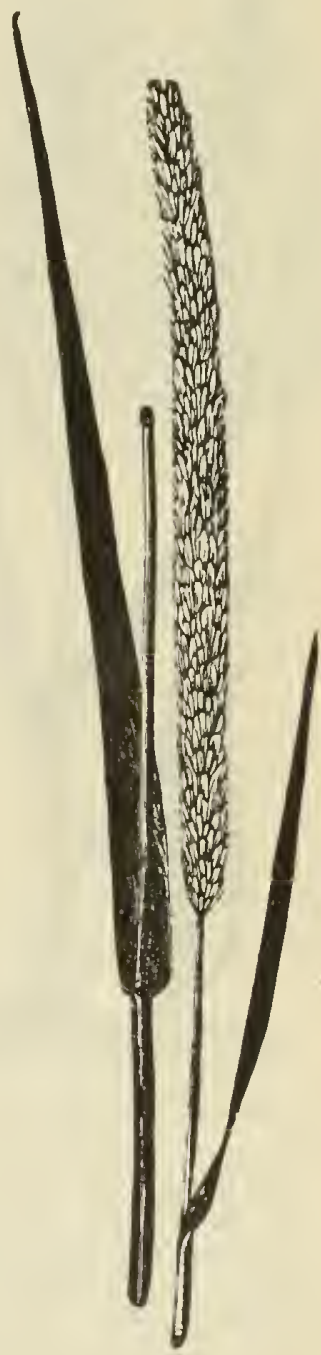

Tiмотну.

(Phleum pratense.) condition, but with proper management no grass is more valuable. When pastured Orchard Grass should never be allowed to become coarse, but should be kept closely cropped. In this condition it is highly nutritive, and relished very much by all kinds of stock.

KENTUCKY BLUE GRASS (Meadow Grass, June Grass, Spear Grass), (Poa pratensis). Root creeping; perennial; flowers in June. This valuable grass is very common in the soils of America, and is claimed by some to be the most valuable of all the grasses in our pastures. On the other hand, some claim that its creeping root impoverishes the soil. It is a fact, however, that it grows very luxuriantly, producing the most nourishing food for cattle until late in the season in the North, while in the South abundant herbage is furnished throughout the entire winter. It is a very valuable species in lawn mixtures. Kentucky Blue Grass requires about two or three years to become well set, and does not arrive at perfection as a pasture grass until the sward is at least four years old, hence it is not suited for alternate husbandry, or where the land is to remain in grass two or three years, and be then plowed up. 


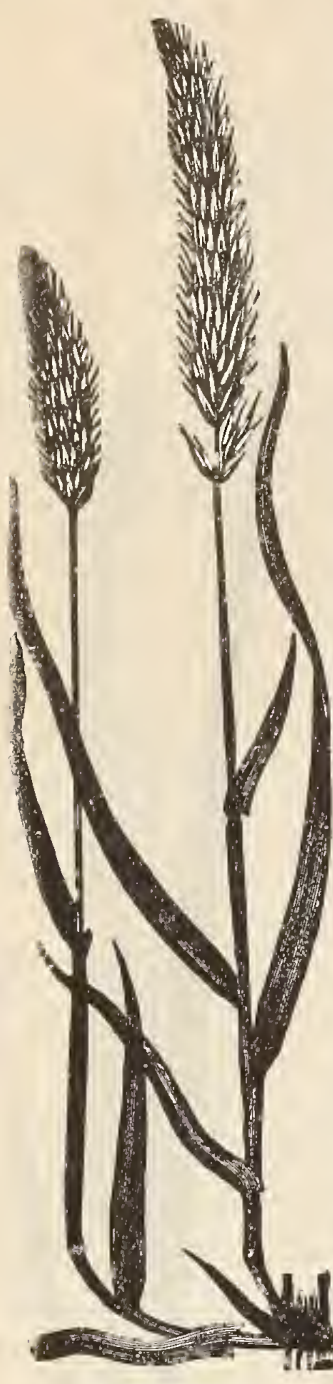

Sweet Vernal.

(Anthoxanthum odoratum.)

RED TOP (Herd's Grass), (Agrostis vulgaris). Root creeping; perennial; flowers in July. This valuable grass has been commonly cultivated in our fields for over a century. It is a fine permanent grass, and forms a nutritious pasturage when fed close. It is valuable for all wet soils, producing a large return in good hay. Red Top is often sown with Timothy and common Red Clover, in which case the Clover soon disappears followed by Timothy, after which the Red Top usually takes its place, and with some wild indigenous grass forms a close sward. When sown alone two to three bushels per acre are required.

RHODE ISLAND BENT (Agrostis canina). Root creeping; perennial; flowers in July. A most valuable permanent grass, largely used in New England for pastures and for lawns. For the latter purpose it is often sown by itself; and if cheapness is an object perhaps it is as good as could be sown, but we recommend the lawn mixture wherever practicable. Soil and treatment same as for Red Top (A. vulgaris).

ROUGH STALKED MEADOW GRASS (Poa trivialis). Root fibrous; perennial. This grass is valuable on account of its quick growth, productiveness, and nutritive qualities. Grows in perfection on moist, rich soils, and is also well adapted to ground iaded by trees. Grows early in the Spring, and continues green until late in the Fall. As it delights in shelter, its produce is always much greater when sown with other grasses. Cattle, sheep, and horses show a great partiality for it, and the pasture is generally eaten barest where this grass predominates. Does not thrive well on dry soils.

PERENNIAL RYE (Lolium perenne). A very valuable grass; arrives early at maturity, and produces a good supply of herbage, of which cattle are very fond. It grows freely on almost any soil, and shows a very early Spring growth. Although a perennial grass, the root will not live over three or four years, and unless the plant is allowed to reproduce from self-sown seed it will die out in about that time. This is an objection to its extensive use for permanent pastures, but for hay crops it may be introduced to good advantage along with other grasses and clovers.

ITALIAN RYE (Lolium Italicum). This is one of the most valuable grasses brought into notice during the present century. In nutritive value, earliness, and quickness of growth after it has been mown, it by far surpasses the Perennial Rye Grass. It is, therefore, indispensable for alternate husbandry; but as it does not last over two years it is of no use in permanent pastures. The

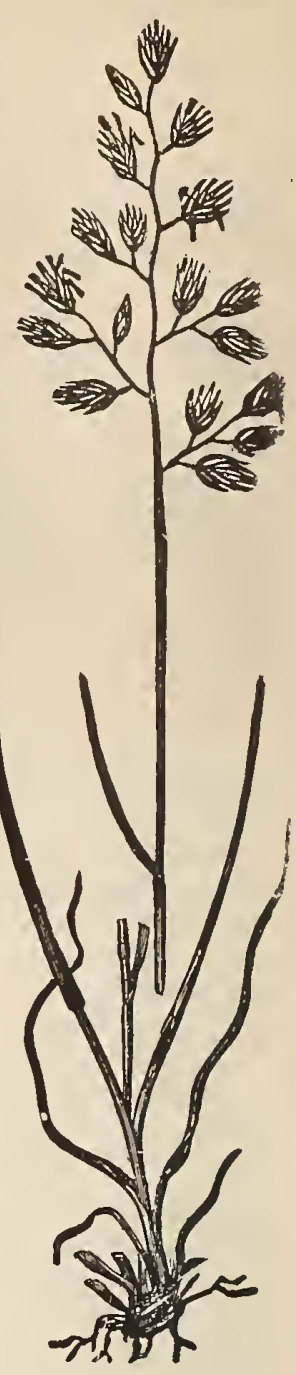

ROUGH-STALKED MEADOw

(Poa trivialis.) wils best adapted to Italian Rye seem to be those that are moist, fertile, and tenacious, or of a medium consistency, and of uch soils it is said to be one of the best grasses known to cut green, affording repeated luxuriant and nutritive crops.

FOWL MEADOW (False Red Top, Duck Grass, Swamp Wire Grass), (Poa serotina). Root slightly creeping; flowers in July and August. This perennial native grass is found on lowlands in many places, though it seldom takes full possession of the soil unless seed is sown. It has been largely introduced into New England, and is particularly adapted to moist, rich soils, such as the borders of rivers, ponds, etc., owing to the fact that an occasional overflow will not injure its growth. It may be mown at any time from June to October, as it never becomes so coarse and hard but the stalk is sweet and tender and eaten without waste. It makes an excellent grass for oxen, cows, and sheep, but is thought too Gne for horses. It is easily made into hay which is of a nutritive character.

MEADOW FOXTAIL (Alopecurus pratensis). Root fibrous; perennial; flowers in May. This is one of the best grasses for permanent pastures, and should always form a fair proportion of the mixtures for that purpose, because of its extremely rapid growth and great nutritive qualities. Thrives best on a rich, strong soil. As the Meadow Foxtail shoots up its flowering stalk much earlier than Timothy, it can be easily distinguished from the latter, which, at first sight, it greatly resembles. It endures the cropping of cattle and sheep probably better than any other variety of grass, making it, as stated above, wellnigh indispensable in all first-class permanent pastures. The nutritive qualities of Meadow Foxtail are mos! abundant at time of flowering.

CRESTED DOG'S-TAIL (Cynosurus cristatus). Roots fibrous and tufted; perennial. This is a most valuable permanent pasture grass. It is very tender and nutritious at time of flowering. If, however, it is left until the seed ripens, cattle will not eat it on account of its wiry stems. For parks this grass is well suited, because of its fine, close growth, and pleasant green color. It should form a portion of all mixtures for lawns.

MEADOW FESCUE (Festuca pratensis). Root creeping; perennial; flowers in July; one of the most valuable of the Fescue grasses. This grass is well adapted for permanent pastures, and is also sometimes used for alternate husbandry. It grows rapidly in rich and rather moist soils, and makes an excellent pasture grass, its long tender leaves being much relished by cattle. It should be always sown mixed with other grasses. 


\section{MILLETS.}

COMMON MILLET (Panicum Miliaceum). Requires a dry, light, rich soil, and grows two and a half to four feet high, with a fine bulk of stalks and leaves, and is excellent for forage. For hay, sow broadcast one-half bushel per acre, from May first to August first. For grain, sow in drills, one peck to the acre, and not later than June 2oth.

GERMAN, OR GOLDEN MILLET (Panicum Miliaceum var.). An improved variety, medium early, growing three to five feet high. The heads are closely condensed, though the spikes are very numerous. The seeds are contained in rough, bristly sheaths, and are round, golden yellow, and bcautiful in appearance.

From close observation during the past few years, the fact has been established beyond doubt that seed of the German or Golden Millet grown in southern latitudes will produce a much larger yield of hay than from seed grown in northern or western sections of the country, and for that reason is far better for farmers to sow. We have a good stock of southern grown seed, and, knowing its value, confidently recommend it. Bear in mind that to the farmer, southern grown seed is worth double that of northern or western grown, as that seed is degenerated and hybridized with other millets.

HUNGARIAN GRASS (Panicum Germanicum). This is a species of millet, growing less rank, with smalle, stalks, often yielding two or three tons of hay per acre. It is very popular and valuable with those who are clearing timbet lands. Like the common millet, it is an annual. and requires to be sown every season, but will produce a larger return thas almost any other crop.

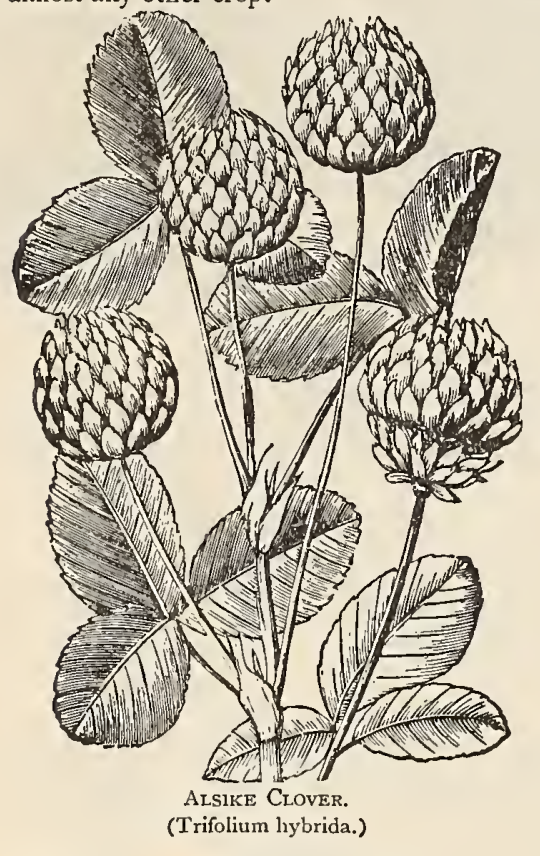

\section{CLOVERS.}

There are no plants so valuable for fertilizers as the Clover. They have the faculty of absorbing nitrogen from the air, and also of rendering availabie much of the inert plant food of the soil. Their long, powerful tap roots penetrate to a great depth, loosen the soil, admit air, and by their decay add immensely to the fertility of the soil.

MEDIUM RED (Trifolium pratense). This is the common Red Clover in general cultivation, and too well known to need a general description. It is by far the most important of all varieties for the pracical purooses of agriculture. When sown alone produces hay of splendid quality, and with Timothy or other grasses forms a desirable pasture.

MAMMOTH, or PEA VINE (Trifolium pratense var.). Grows five or six feet high; its stalks are so coarse and large that stock will eat only the ieaves, but by its judicious use lands which have been exhausted can be reclaimed, as it will grow where
the common clover will fail.

ALSIKE or SWEDISH (Trifolium hybridum). This is the most hardy of clovers, and is fast gaining popularity. It resists cold and extreme drought and wet, and on rich moist soil yields an enormous amount of hay or pasture of a nutritive quality. Can be cut several times in a season. It is well suited to low lands liable to wash, as its long, fibrous routs spread over a large area and hold the soil so as to resist

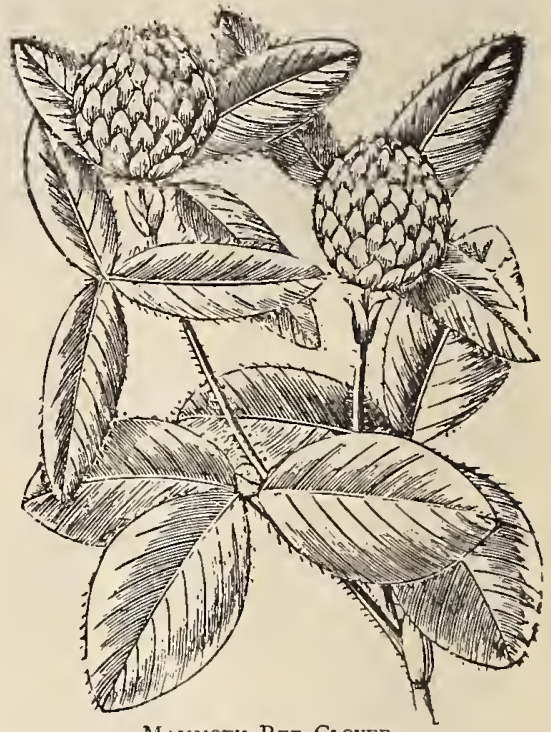

Mammoth Red Clover.

(Trifolium pratense var.)

the heaviest rains. The heads are globular, ver: sweet and fragrant, and much liked by bees, whe obtain a large amount of honey from them.

LUCERNE or ALFALFA (Medicago sativa), Where this variety succeeds well it is probably onc of the most valuable of all clovers. It is not, hun ever, particularly adapted to the Eastern or Northerr. States, but flourishes in all Western and Suuthern. It requires a fine mellow soil to get it firmly established, but when once thoroughly fixed will produce a profitable crop for a number of years. It yields an encr. mous amount of green fodder, and should be cut when commencing to blossom. Although a prodigious yielder, it does not exhaust the soil, but on the contrary improves it. In States to which it is arlapted, four or five crops can be obtained in one season.

WHITE CLOVER (Trifolium repens). The value of this Clover to the farmer is well known, and it is to be found in nearly every natural pasture. It is adapted to all soils. Being a deep-rooted plant, it withstands drought on dry, sandy sections. It should form a part of all mixtures for permanent pastures, and is also valuable for alternate husbandry, when these crops are sown down for more than one year.

CRIMSON CLOVER (Trifolium incarnatum). Is also known as Scarlet Clover and Carnation Clover. It is of rapid growth, and of great value where only one crop is desired, sown either alone or with Italian rye grass. It is an immense yielder, and can be fed green or made into hay. It may be sown in the fall for an early summer crop, or in the spring for cutting in July. 


\title{
MIXTURES FOR PERMANENT PASTURES.
}

\author{
"One thing is certain: that groot pasture land is the foundation of the riches of a farm." - SINCLAIR.
}

The oft-repeated complaints of wornout ancl cxhausted pastures, made to us by some of our best New England farmers, have long impressed us with the fact that there must be something radically wrong with the manncr in which our pastures

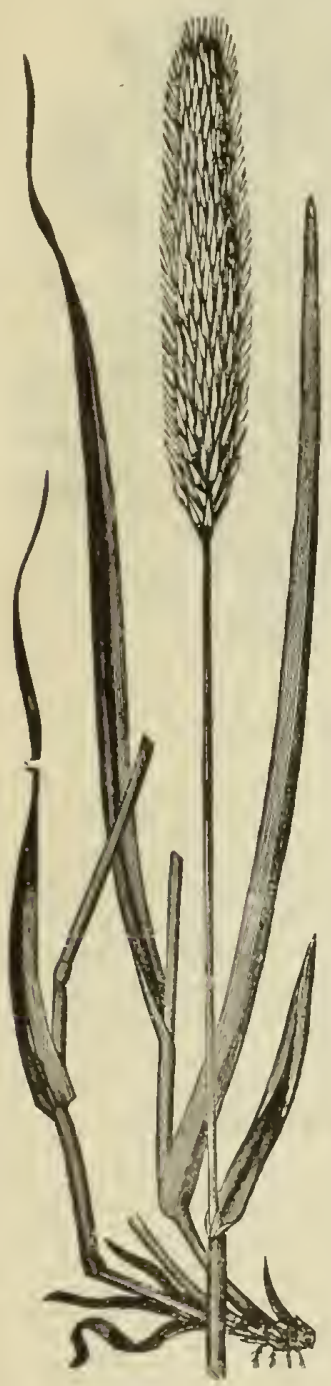

MEADOW FOXTAIL. (Alopecuris pratensis.)

Poa nemoralis, Alopecuris pratensis, Dactylis glomerata, Festuca pratensis, are formed and cared for. Some remedy for this state of matters is imperatively necessary, and it seems to us that one most important line of improvement would be the sowing of a larger number of species of grasses in the laying out of these pastures.

As we have already expressed as our opinion, farmers, as a rule, in prcparing their mixtures of grasses to be used in the laying down of permanent pastures, confine themselves to too few varieties, thus failing to arrive at the most profitable results. The chief properties which give value to a grass are nutritive powers, produce, early growth, and reproductiveness (that is, the property of growing rapidly after being cropped). If one species of grass could be discovered that possessed all these qualities in a superior degree to every other, there would be no necessity beyond that of botanical science for us to acquire the knowledge which enables us to distinguish the different species of grasses, the soils and subsoils best adapted to their growth, natural habits, and comparative value; but the results of all experiments have proven that a combination of all the merits and properties which give value to a grass is not to be found in any single species, or in fact in any two or three. In sowing a mixture of a number of different varieties we are but following nature, who can be always depended upon as the best teacher. This can easily be demonstrated by the careful examina. tion of any old, rich, permanent pasture, on which will invariably be found fifteen to twenty specics of grass or forage plants growing in great profusion. Where, however, it is left to nature to supply the necessary plants to make a rich and succulent pasturage, a great deal of valuablc time is of necessity lost, as seven or eight years will elapse before the field will naturally assume the character of a rich and profitable pasture, while by arificial means the same result can be brought about in one fourtis the time.

In compiling any table of grasses and clovers to be used for permanent pasture purposes there are several important features to be taken into consideration. First, the proportion of plants which would be produced from the amount of each kind of seed sown should be determined, so that the undue predominance of any particular variety may be avoided. We have given this point special consideration in preparing our mixtures. A selection of grasses should be made that blossom at alternate months of the year, as it is a well-known fact that there is no month from April to September, inclusive, in which some of the valuable grasses do not attain their full perfection.

The species which afford the principal grasses in Spring are:-

(Wood Meadoni)
(Meadow lioxtail).
(Cocksfoot).

Phleum pratense,

Anthoxanthum odoratum,

(Meadow Fescue).

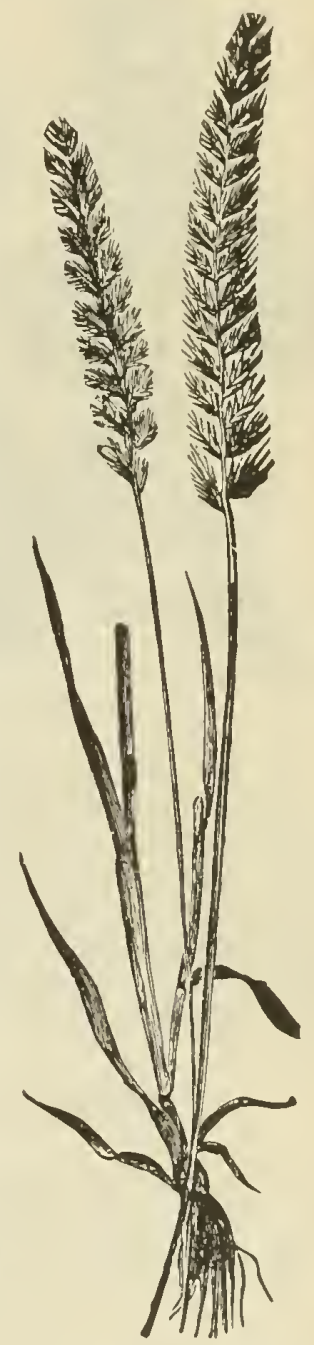

Crested Dogstail. (Cynosurus cristatus.)

The species which afford the principal grasses in Summer are:-

$\begin{array}{ll}\text { Festuca pratensis, } & \text { (Meadow Fescue). } \\ \text { Phleum pratense, } & \text { (Timothy). } \\ \text { Lolium perenne, } & \text { (Rye Grass). } \\ \text { Agrostis vulgaris, } & \text { (Red Top). } \\ \text { Poa pratensis, } & \text { (Blue Grass). } \\ \text { Festuca elatior, } & \text { (Tall Fescue). }\end{array}$
(Meadow Fescue).
Timothy).
Red Top).
Tall Fescue)

Trifolium pratense,

Trifolium hybridum,

Trifolium repens,

Cynosurus cristatus,

Dactylis glomerata,
(Timothy).

(Sweet Vernal)

(Perennial R'ye Grass).

The spccics which aîora the principal grasses in Autumn are:-

$$
\text { Fest }
$$

F
A
C
F
I$$
\text { Yellow Oat Grost }
$$$$
\text { (Tellow Gass) }
$$$$
\text { Hard Fogstail). }
$$$$
\text { (Rough Sialked Meadow). }
$$

Poa pratensis,

Trifolium pratense, Trifolium hybridum, Trifolium repens,
(Red Clover). (Alsike Clover). (White Clover). (Crested Dogstail). (Cocksfoot). 
By using a mixture comprising these species, it will be at once apparent that a rich and luxuriant growth will be secureo throughol the entire season, which result cannot possibly be obtained if the stereotyped mixture usually recommended com. poses the sward. It would be almost impossible for us to give a series of tables which would comprehend all the variations of soils, altitudes, and climates. We think, however, that those which we have compiled will be found sufficiently comprehensive

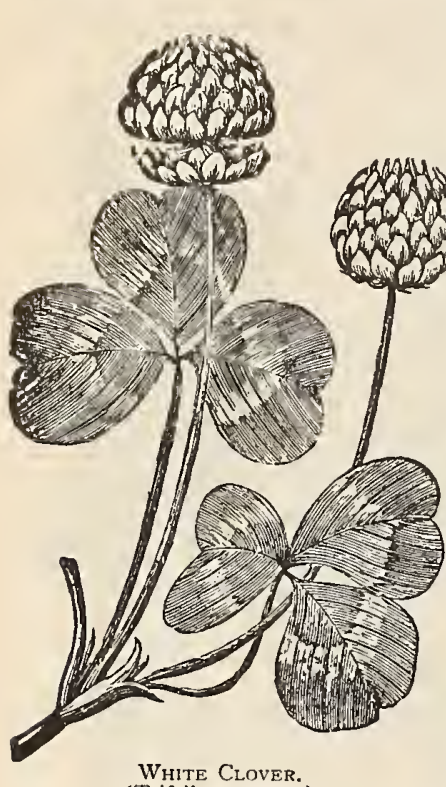

(Trifolium repens.) to meet nearly ail the contingencies that arise in ordinary farming.

These mixtures, which we recommend only after careful study and consultation with the best authorities, are of little or no value unless the seeds composing them are absolutely pure and true to name. We, therefore, especially request those who desire to obtain the best results from their mixtures for alternate husbandry, mowing lands, and permanent pastures, to avoid the probability of disappointment which would naturally attend the placing of orders with parties who have never given any degree of attention to this most important subject, and buy from us direct (or authorized agents), who are the first in this country to make a specialty of this branch of the seed business. We doubt if a full stock of all the grasses which form the components of our mixture could be found anywhere in the United States outside of our own estab. lishment, and know they cannot be obtained in the same quantities and of equal quality.

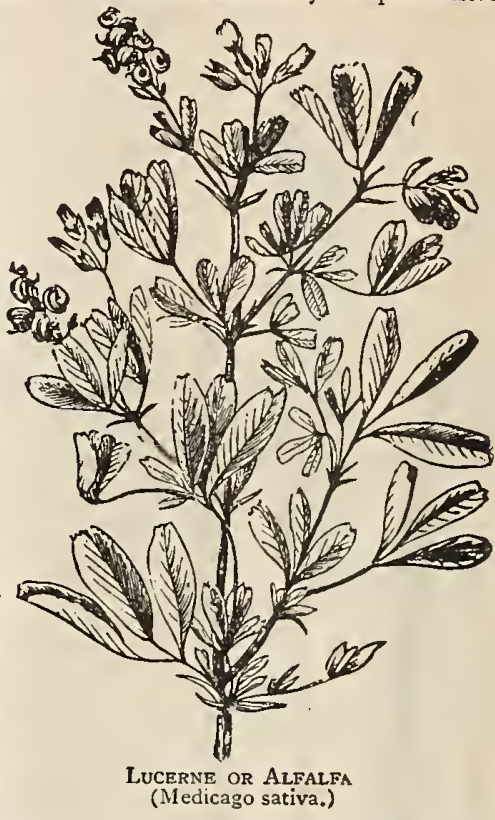

In conclusion, we would say, that although pastures be formed in the best manner as recommended by us, with a com. bination of MANY different species of grasses, yet a judicious mode of treatment afterwards is as necessary to continue they value. By proper stocking and top-dressing, very indifferent pastures may be brought to a state of great fertility; but, or the contrary, the richest pastures by neglect of proper stocking, top-dressing, or by the too frequent repetition of hay crops, will become so unprofitable as to require many years to bring them again to their original value. This fact every practical farmer is well aware of, and after the proper mode of sowing and stocking has been determined on, a suitable top-dressing should be found. Under the head of Fertilizers, in another part of this Catalogue, will be found a reliable top-dressing which we can strongly recommend as being specially adapted for pastures of this character.

\section{BRECK'S SPECIAL MIXTURES FOR PERMANENT PASTURES.}

Table showing the proper quantities to Sow on an Acre of Light, Medium, or Heavy Soils, for Permanent Pasture.

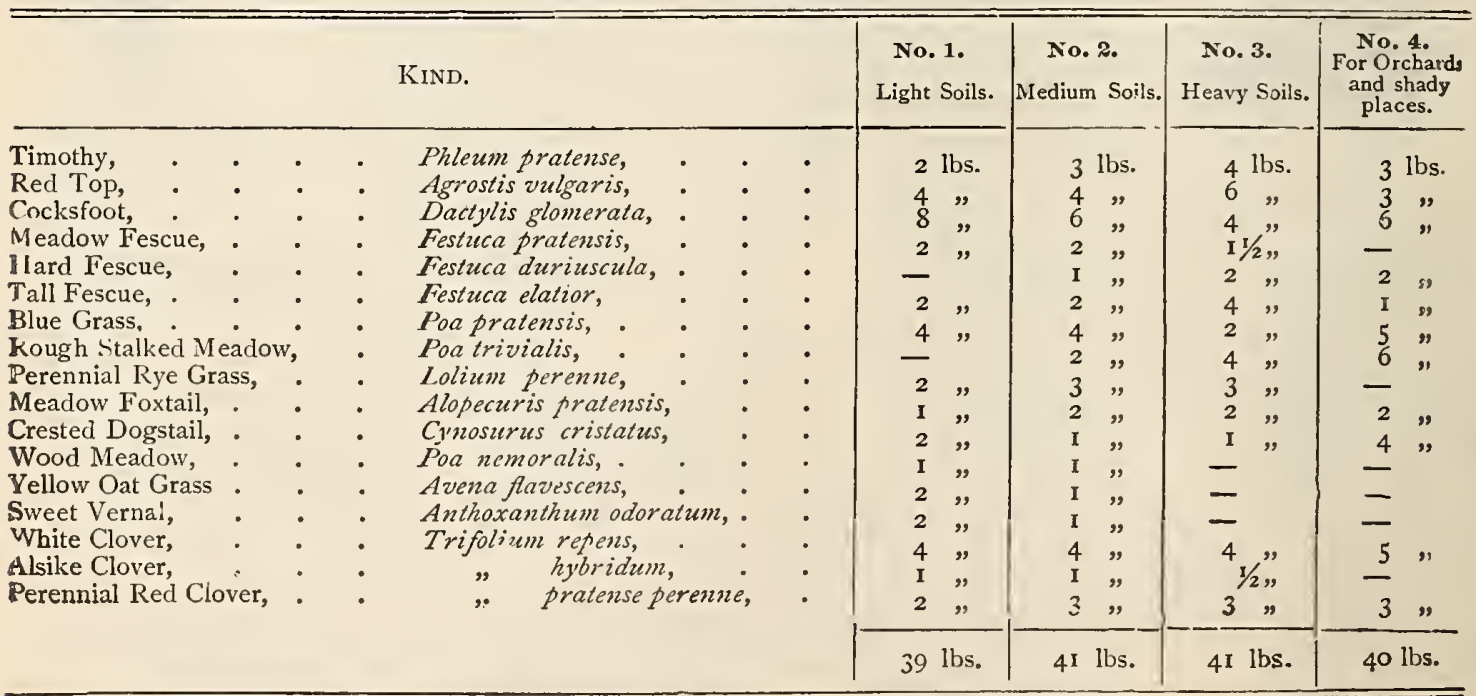




\section{Alternate Husbandry.}

\section{MIXTURES FOR MOWING AND GRAZING LANDS.}

As the pioneers of grass mixtures in this country, we naturally have great pleasure in learning from day to day and ieason to season that our remarks under the heading, "Mixtures for Permanent Pastures," are fast becoming universally admitted facts; and we predict, with confidence, that the time is not far distant when the practice of sowing only one or two varieties of grass seeds with the hope of obtaining the best results from it will pass, and the better and more profitable one of following nature's plan be adopted.

Many of our statements regarding Permanent Pasture Mixtures are equally pertinent when applied to Alternate Husbandry. It does not require much thought to convince any practical agriculturist that there is no basis to a system that employs the same quantity and kinds of grass seeds on all occasions, without regard to soil, duration of lay, or the condition in which the crop is to be used. All mistures for Alternate Husbandry should include, say for one or two years' lay, only annual and biennial or other sorts that attain full maturity within that period; for two or three years' lay a greater quantity of seed is required, which should embrace a larger proportion of permanent sorts, so that the places of the dead annual kinds may be filled by the varieties that are of slower growth.

If a mixture, principally for mowing, is intended to lay more than three or four years, especial care is necessary in selecting and adjusting the several varieties of grasses in proper proportion. A three or four years' lay sown with grasses that are only of annual or biennial duration must be either very thin or foul at the end of the period for which it was laid down - the spaces vacated by the annual and biennial grasses being in all likelihood occupied by objectionable weeds, when, if a proper selection of those species capable of lasting the whole of the desired period were sown, the lay would remain full of plants, free from weeds, and, consequently, much more profitable during the whole time the land is in grass.

The practice of mowing grass for hay when the plants are in blossom is acknowledged to be a good one, in that it is not so exhausting to the soil, and a more succulent hay, freer from dust, is obtained; it has, however, from the fact that all natural reseeding is prevented, a tendency to weaken the plants and reduce their number; hence when we see an old field of grass that was originally sown with Timothy, Redtop, and Clover, and which has been mowed, perhaps, twice annually, we can readily account for either the enormous number of weeds or vacant places that are sure to be noticeable. Our system of mixtures practically overcomes this difficulty by the continued growth and stooling out of some of the varieties included that do not attain full maturity under four to six years. Such mixtures, although in the first place more expensive than the ordinary orthodox seeding, are in the end more profitable; we have seen aftermaths from permanent mowing mixtures that more than equaled first crops of Timothy.

In making up the following tables the utmost care has been exercised, and we have no hesitation in recommending them to our patrons.

\section{BRECK'S SPECIAL MIXTURES FOR MOWING AND GRAZING LANDS.}

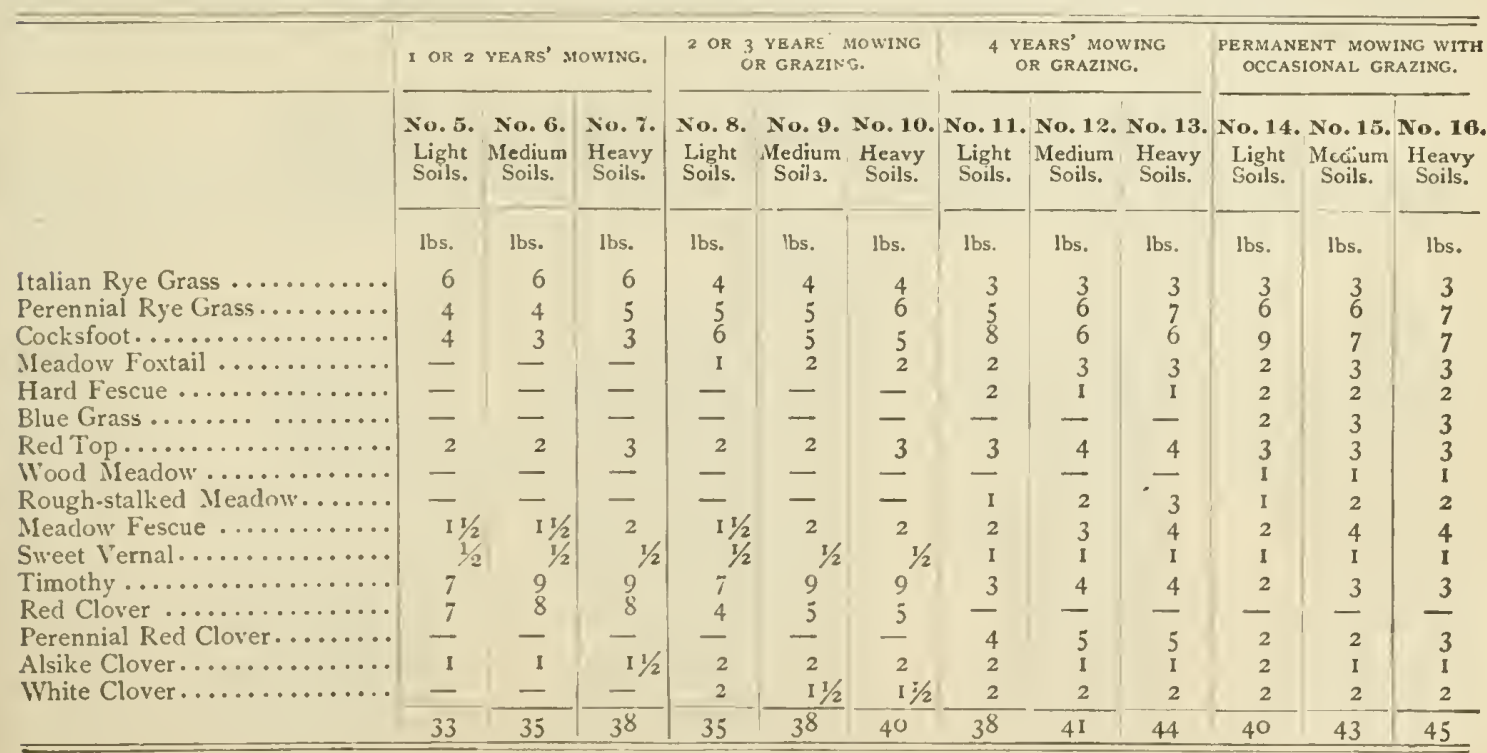




\section{NOTE.}

It will be noticed that the different tables are all based on the quantity required to sow one acre, so in orderng, our patrons will please state the number of acres for which the seed is desired. We shall, unless we are especially instructed to the contrary, put up each variety of seed in separate packages, packing the entire quantity necessary for one acre in a case. We recommend our friends to always buy their mixtures put up as above, and to refuse to receive them in any other shape. The advantage of buying the seed before it is mixed is very apparent, as it insures the purchaser obtaining the exact varieties and quantities which should compose the mixture he has ordered. This protec. ton cannot be enjoyed where the seed is mixed before it is sent out.

\section{PRICES FOR JOSEPH BRECK \& SONS' SPECIAL MIXTURES FOR PERMANENT PASTURES AND MOWING AND GRAZING LANDS.}

When o iering, simply give number and kind of mixture selected and the number of acres for which seed is desired; for example: "Send me No. 2 Mixture for Permanent Pastures for three acres."

\section{PERMANENT PASTURES.}

\begin{tabular}{c|c|c|c|c|}
\hline For Light Solls. & For Medium Solls. & For Heavy Solls. \\
\hline $\begin{array}{c}\text { No. 1. } \\
\text { Price per Acre. } \\
\$ 10.00 .\end{array}$ & $\begin{array}{c}\text { No. 2. } \\
\text { Price per Acre. } \\
\$ 10.00 .\end{array}$ & $\begin{array}{c}\text { No. 3. } \\
\text { Price per Acre. } \\
\$ 9.50 .\end{array}$ \\
\hline
\end{tabular}

\section{ALTERNATE HUSBANDRY.}

\begin{tabular}{|c|c|c|c|c|c|c|c|c|c|c|c|}
\hline \multirow{2}{*}{$\begin{array}{c}\text { FOR I OR } \\
\begin{array}{c}\text { No. 5. } \\
\text { Light } \\
\text { Soils. }\end{array}\end{array}$} & \multicolumn{2}{|c|}{2 Years' Mowing. } & \multicolumn{3}{|c|}{$\begin{array}{c}\text { FOR } 2 \text { OR } 3 \text { YEARS' MOWING OR } \\
\text { GRAIING. }\end{array}$} & \multicolumn{3}{|c|}{$\begin{array}{c}\text { For } 3 \text { OR } 4 \text { YEARs' MowING or } \\
\text { GRAZING. }\end{array}$} & \multicolumn{3}{|c|}{$\begin{array}{l}\text { Permanent Mowing witil } \\
\text { Occasional Grazing. }\end{array}$} \\
\hline & $\begin{array}{c}\text { No. } 6 . \\
\text { Medium } \\
\text { Soils. }\end{array}$ & $\begin{array}{c}\text { No. } \% . \\
\text { Heavy } \\
\text { Soils. }\end{array}$ & $\begin{array}{c}\text { No. } 8 . \\
\text { Light } \\
\text { Soils. }\end{array}$ & $\begin{array}{l}\text { No. } 9 . \\
\text { Medium } \\
\text { Soils. }\end{array}$ & $\begin{array}{c}\text { No. } 10 . \\
\text { Heavy } \\
\text { Soils. }\end{array}$ & $\begin{array}{l}\text { No. } 11 . \\
\text { Light } \\
\text { Soils. }\end{array}$ & $\begin{array}{c}\text { No. } 12 . \\
\text { Mediuin } \\
\text { Soils. }\end{array}$ & $\begin{array}{l}\text { No. } 13 . \\
\text { Heavy } \\
\text { Soils. }\end{array}$ & $\begin{array}{c}\text { No. } 14 . \\
\text { Light } \\
\text { Soils. }\end{array}$ & $\begin{array}{l}\text { No. } 15 . \\
\text { Medium } \\
\text { Soils. }\end{array}$ & $\begin{array}{c}\text { No. } 16 . \\
\text { Heavy } \\
\text { Soils. }\end{array}$ \\
\hline $\begin{array}{l}\text { Price per } \\
\text { Acre. }\end{array}$ & $\begin{array}{l}\text { Price per } \\
\text { Acre. }\end{array}$ & $\begin{array}{l}\text { Price per } \\
\text { Acre }\end{array}$ & $\begin{array}{l}\text { Price per } \\
\text { Acre. }\end{array}$ & $\begin{array}{l}\text { Price per } \\
\text { Acre. }\end{array}$ & $\begin{array}{l}\text { Price per } \\
\text { Acre. }\end{array}$ & $\begin{array}{l}\text { Price per } \\
\text { Acre. }\end{array}$ & $\begin{array}{l}\text { Price per } \\
\text { Acre. }\end{array}$ & $\begin{array}{l}\text { Price per } \\
\text { Acre. }\end{array}$ & $\begin{array}{l}\text { Price per } \\
\text { Acre. }\end{array}$ & $\begin{array}{l}\text { Price per } \\
\text { Acre. }\end{array}$ & $\begin{array}{l}\text { Price per } \\
\text { Acre. }\end{array}$ \\
\hline$\$ 5 . \infty$ & $\$ 5.00$. & $\$ 6 . \infty 0$ & $\$ 6.00$ & $\$ 8.5^{\circ}$ & $\$ 8.50$ & $\$ 8.00$. & $\$ 9.50$ & $\$ 10.00$ & $\$ 10.00$ & $\$ 11.00$ & $\$ I I .50$. \\
\hline
\end{tabular}

Special prices for quantities for ten acres and upwards.

While it is true that the mixtures which we have recommended are sEEMINGLY much more expensive than what a commonly used, it should be borne in mind that a vastly increased value is given to the pasture, not only for one year, but if the land is properly cared for it will remain in good condition for fifteen or twenty years without further sowing, and produce double the amount of fodder, while the ORDINARY sowing has to be repeated every three or four years; thus, in the end, costing more than four times as much as what would be paid originally for the proper mixture.

CAUTION. - Appreciating the fact that some unscrupulous parties will probably offer mixtures for permanent pastures, mowing lands, and alternate husbandry, purporting to be the same as ours, we shall, as a matter of protection to both our patrons and ourselves, stencil or print on each case, and also on package containing each variety of seed, our name and address, and request our patrons before purchasing from any other source than ourselves direct, that they examine the case containing same, and if not stenciled as described they may know that IT IS NOT our mixture, and therefore not in any way entitled to our endorsement.

\section{PRICES OF AGRICULTURAL GRASSES AND CLOVERS.}

\section{SUBJECT TO MARKET CHANGES. SPECIAL QUOTATIONS ON APPLICATION.}

\begin{tabular}{|c|c|c|c|c|c|c|c|}
\hline \multicolumn{2}{|c|}{ KIND. } & \multirow{2}{*}{$\frac{\begin{array}{c}\text { Price } \\
\text { per } \\
\text { pound }\end{array}}{\$ 0.30}$} & \multirow{2}{*}{\begin{tabular}{|c}
$\begin{array}{c}\text { Price } \\
\text { per } \\
\text { bush. }\end{array}$ \\
$\$ 2.50$
\end{tabular}} & \multicolumn{2}{|c|}{ KIND. } & \multirow{2}{*}{$\frac{\begin{array}{c}\text { Price } \\
\text { per } \\
\text { pound }\end{array}}{\mid \$ 0.08}$} & \multirow{2}{*}{$\frac{\begin{array}{c}\text { Price } \\
\text { per } \\
\text { bush. }\end{array}}{33.00}$} \\
\hline R. I. Bent & Agrostis canina & & & Timothy & Phleum pratense & & \\
\hline Red Top & Agrostis vulgaris & . Io & .80 & Wood Meadow & Poa nemoralis & .50 & 8.00 \\
\hline Meadow Foxtail & Alopecuris pratensis & .60 & 2.75 & Blue Grass (fancy) & Poa pratensis & .15 & 2.00 \\
\hline Sweet Vernal (true) & Anthoxanthum & & & Fowl Meadow & Poa serotina & .27 & 2.25 \\
\hline & & .75 & 4.50 & Rough Stalked Meadow & $\checkmark$ Poa trivialis & .50 & 9.00 \\
\hline Yellow Oat Grass & Arena flavescens & .60 & 5.00 & Tall Meadow Oat $A$, & rrhenatherum avenceum & .40 & \\
\hline Crested Dogstail & Cynosurus cristatus & .40 & 10.00 & Hungarian Millet Gras & s Setaria germanica & .05 & I.65 \\
\hline Orchard Grass & Dactylis glomerata & .22 & 2.35 & Common Millet & Panicum miliaceum & .05 & 1.50 \\
\hline Hard Fescue & Festuca duriuscula & .35 & 5.00 & Golden Millet & Panicum miliaceum, var. & .05 & 1.75 \\
\hline Tall Fescue & Festuca elatior & .40 & 6.00 & Red Clover & Trifolium pratense & .16 & \\
\hline Sheep's Fescue & Festuca ovina & .30 & 5.00 & Mammoth Red Clover & Trifolium pratense, var. & .18 & \\
\hline Red Fescue & Festuca rubra & .35 & 5.00 & White Clover & Trifolium repens & .30 & \\
\hline Meadow Fescue & Festuca pratensis & .40 & 7.00 & A lsike Clover & Trifoliwm hybridum & .22 & \\
\hline Iraiian Rye Grass & Lolium Italicum & .15 & 2.50 & Lucerne, or Alfalfa & Medicago sativa & .25 & \\
\hline Perenniai Pye Grass & Louzm perenne & .12 & 2.50 & Crimson Clover & Trifolium incarnatum & .20 & \\
\hline
\end{tabular}




\section{INSURE A BEAUTIFUL LAWN BY USING}

\section{BRECK'S LAWN GRASS SEED.}

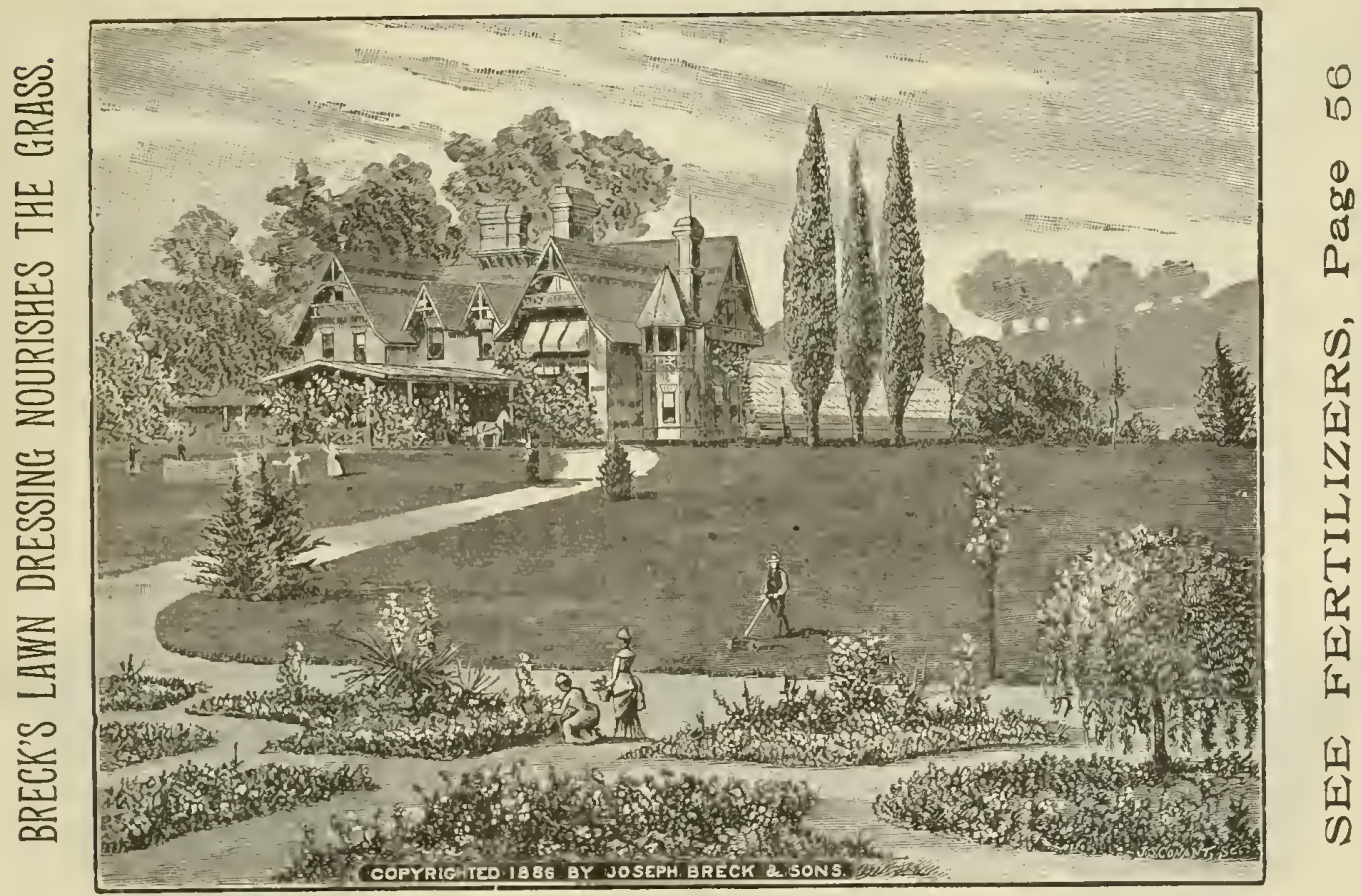

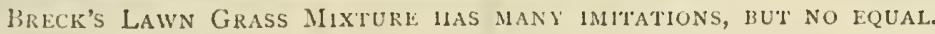

However much care is bestowed upon the garden and the house, no home in the city or country can be considered complete without a thoroughly made, well-kept lawn. The law1: is to the garden what the parlor is to the kitchen; therefore, why not take as much pride in it? It is a great mistake to suppose that grass will grow so as to make a beautiful lawn on unprepared soil. The fact is, as much care must be exercised in the preparation of the soil for the lawn as for vegetables or any other garden crop. First see that the ground is well prepared by deep digging and trenching, for it is vain to expect a lawn to retain its greenness in the scorching days of July and August unless the ground is thoroughly pulverized, so that the roots of the grass can penetrate at least two feet deep. Wherever necessary the ground should be drained, thoroughly manured, plowed, and harrowed, and all stones or roots removed. After the soil has been thus prepared, it should be made perfectly level — for if this is not done before the seed is sown, it cannot be done after the sward is formed without great expense and inconvenience - and left to settle a week or tcn days; then it should be raked smooth, after which it is ready for the seed. We have given much tnc ught and made many experiments, in order to ascertain just what is the best mixture for permanent lawns, and what grasses ar best suit d so this climate. By the proper blending of the varieties which constitute Breck's Lawn Grass we have obtainer a mixtine that, from early Spring to late Fall, will give to lawns made with it that rich, deep-green so often admired up:n the iawns and parks of England, but so seldom seen in this country. Sow at the rate of sixty to seventy pounds to the acre. The use of stable manure as a fertilizer should be avoided, as it always contains noxious weeds, and other more or less foreign seeds; and we especially recommend the use of Breck's Lawn Dressing, which will give the grass nourishment throughout the entire season, producing a rich, luxuriant growth of a rich, deep-green color. The lawn, after being properly prepared, should be neatly kept by rolling with a light garden roller. Frequent cutting of the grass after it attains a certain height produces a soft, velvety growth which cannot otherwise be obtained. For this purpose we know of nothing that will so efficaciously do the work as the Philadelphia Lawn Mower.

One quart will sow 300 square feet One-half peck will sow $\mathbf{1}, 200$ square feet One peck will sow 2,400 square feet (O) he hushel will sow 10,000 square fcct Four bushels will sow one acre.
Price: per quart, $\$ 0.25$

“ $\frac{1}{2}$ peck, .75

" peck, 1.,5

" bush, 7 u 
GARDEN AND FARM REQUISITES, ETC.

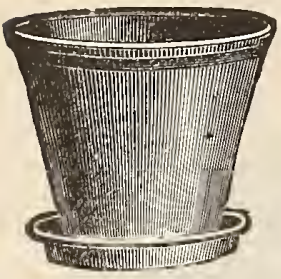

FLOWER-POTS, SEED PANS, ETC.

Special offer No. 2 only applies to Flower and Hanging Pots.

We handle a full line of all the different sizes and patterns of flower-pots and saucers, seed pans, fern pans, orchid pots, hanging vases, and fancy ware of all kinds, not less than 50 of a size supplied at roo rate.

The Measurement is from Outside to Outside. Packing Charged Extra.

\begin{tabular}{|c|c|c|c|c|c|c|c|c|c|c|c|c|c|}
\hline \multicolumn{3}{|c|}{ FLOWER-POTS. } & \multicolumn{2}{|c|}{ SAUCERS. } & \multicolumn{3}{|c|}{ FLOWER-POTS. } & \multicolumn{2}{|c|}{ Saucers. } & \multicolumn{2}{|c|}{$\begin{array}{c}\text { Round } \\
\text { SEED PANS. }\end{array}$} & \multicolumn{2}{|c|}{$\begin{array}{c}\text { SQUARE } \\
\text { SEED PANS. }\end{array}$} \\
\hline $\begin{array}{l}\text { Size. } \\
\text { Inches. }\end{array}$ & $\begin{array}{c}\text { Price } \\
\text { Per Doz. }\end{array}$ & $\begin{array}{c}\text { Price } \\
\text { Per roo. }\end{array}$ & $\begin{array}{c}\text { Price } \\
\text { Per Doz. }\end{array}$ & $\begin{array}{c}\text { Price } \\
\text { Per 100. }\end{array}$ & $\begin{array}{l}\text { Size. } \\
\text { Inches. }\end{array}$ & $\begin{array}{c}\text { Price } \\
\text { Per Doz. }\end{array}$ & $\begin{array}{c}\text { Price } \\
\text { Per Io0. }\end{array}$ & $\begin{array}{c}\text { Price } \\
\text { Per Doz. }\end{array}$ & $\begin{array}{c}\text { Price } \\
\text { Per Io. }\end{array}$ & $\begin{array}{l}\text { Size. } \\
\text { Inches. }\end{array}$ & $\begin{array}{l}\text { Price } \\
\text { Each. }\end{array}$ & $\begin{array}{l}\text { Size. } \\
\text { Inches. }\end{array}$ & $\begin{array}{l}\text { Price } \\
\text { Each. }\end{array}$ \\
\hline $21 / 2$ & \$o. I5 & $\$ 0.90$ & $\$ 0.15$ & \$I.IO & 7 & $\$ 0.95$ & $\$ 7.50$ & $\$ 0.55$ & $\$ 3.25$ & & & $6 \times 6$ & $\$ 0.20$ \\
\hline 3 & .20 & I. 15 & . I 5 & 1.20 & 8 & I. 3.5 & I0.00 & .60 & 4.25 & 6 & .07 & $8 \times 8$ & .25 \\
\hline $31 / 2$ & .25 & I. $40^{\circ}$ & .18 & I. 25 & 9 & 1.65 & 13.50 & .75 & 5.25 & 8 & . I0 & I OXIo & .30 \\
\hline 4 & .30 & 2.00 & .25 & 1.50 & 10 & 2.40 & 17.50 & .95 & 6.50 & IO & . I 5 & $\mathrm{I} 2 \mathrm{XI} 2$ & .40 \\
\hline 5 & .50 & $3 \cdot 25$ & .30 & 2.00 & I I & 3.50 & 23.00 & 1.20 & 8.00 & 12 & .20 & & \\
\hline 6 & .70 & 4.50 & .40 & 2.50 & 12 & $4 \cdot 75$ & $3^{1} \cdot 5^{\circ}$ & I. 75 & 12.00 & 14 & .40 & & \\
\hline
\end{tabular}

\section{FANCY HANGING POTS.}

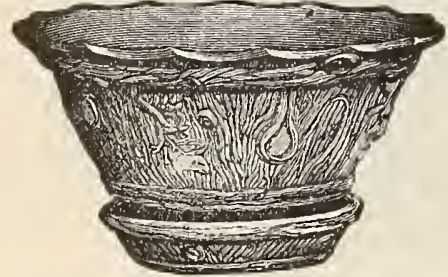

No. 16 .

No. 16,7 in., per doz.

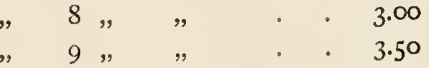

Patent Extension Hanger.

No. I16, Steel, per doz. . . \$1.8o " II 7, Brass, , . . 2.00

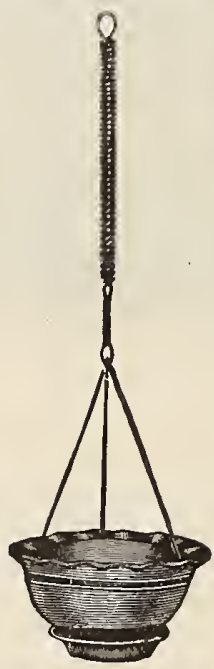

Hanging Pot Chains.

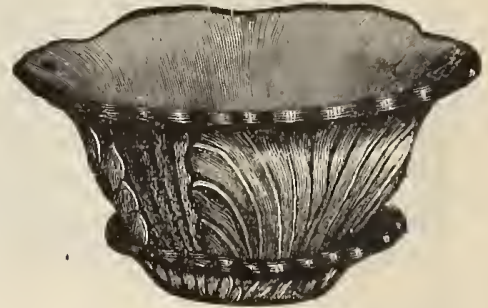

No. 18.

No. 18,7 in., per doz. . . $\$ 3.00$

, $8, " . \quad 4.00$

" $9, \quad . \quad 5.30$

Brass Jack Chain.

No. I1 8,3 strand, per doz. . $\$ 2.00$ , 119,4

WOOD POT LABELS.

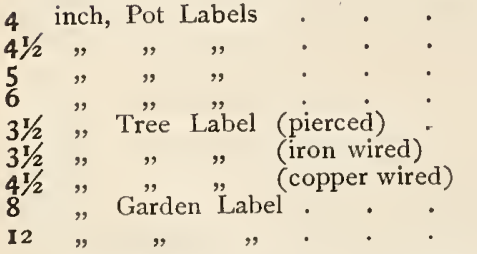

\begin{tabular}{|c|c|c|c|c|c|}
\hline & Plain. & Painted. & & \multicolumn{2}{|c|}{ Plain. Painted. } \\
\hline per 100 , & $\$ 0.15$ & $\$ 0.20$ & per 1000, & & \\
\hline " & .15 & .20 & , & .70 & .90 \\
\hline " & .15 & .20 & $"$ & .80 & 1.00 \\
\hline " & .15 & .20 & $"$ & 1.00 & 1.20 \\
\hline , & .15 & .20 & $"$ & .60 & .80 \\
\hline , & .15 & .20 & ", & 1.00 & 1.25 \\
\hline , & .20 & .25 & $"$ & 1.50 & I. 75 \\
\hline$"$ & .40 & 一 & ", & $3 \cdot 5^{\circ}$ & - \\
\hline$"$ & $.5^{\circ}$ & 一 & ", & $4 \cdot 5^{\circ}$ & \\
\hline
\end{tabular}

Flower Stands. Made very firmly of ash, and varnished; half circle shape; 3 feet 2 inches in height; 3 shelves. Each, \$1.25. 4 shelves : 3 feet 8 inches in height, each $\$ \mathbf{I} \cdot 75$

Rustic Work. The different articles are made of natural roots and knots; very durable and artistic.

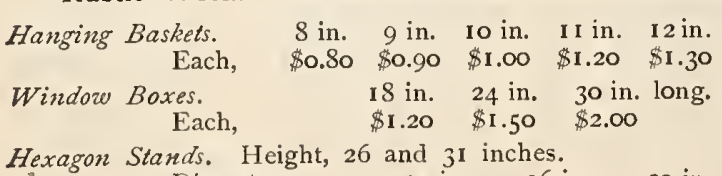

Diameter, 14 in. 16 in. 20 in. Each, \$1.70 \$2.50 \$3.00
Oblong Stands. Height, 24 in. 28 in. Each, \$2.50 \$3.00 \$5.00

Arm Chair, No. 3. Each, $\$ 5.50$.

Rustic Settee.

Length of seat, $\quad 2 \mathrm{I} / 2 \mathrm{ft} . \quad 3 \mathrm{l} / 2 \mathrm{ft} . \quad 4 \mathrm{t} / 2 \mathrm{ft}$. Each $\quad \$ 5.00 \quad \$ 7.00 \quad \$ 8.00$ 


\section{WIRE FLOWER-POT STANDS.}

Special offer No. 2 only applies to Wire Flower-pot Stands and Tomato Trellises.

These stands are most desirable either for household use or for conservatories and other purposes. Thr are elegantly made, painted a beautiful green, mounted on porcelain castors, and finished with gold bronze, making them very attractive and ornamental.

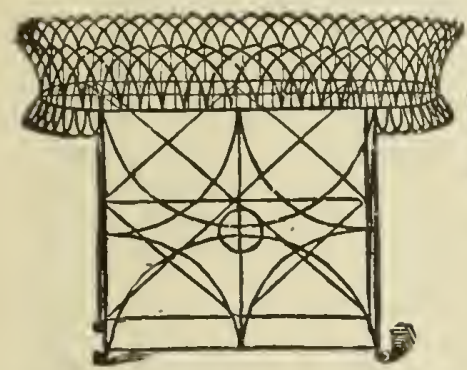

No. I, \$2.50.

Jblong Stand, 24 in. high, 30 in. long, $9 \frac{1}{2}$ in. wide.

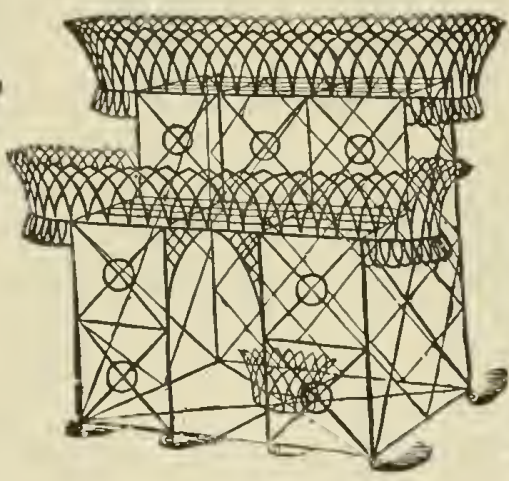

No. $2, \$ 3.25$.

Square Stand, with 2 shelves, 33 in. high, 18 in. deep, 33 in. long.

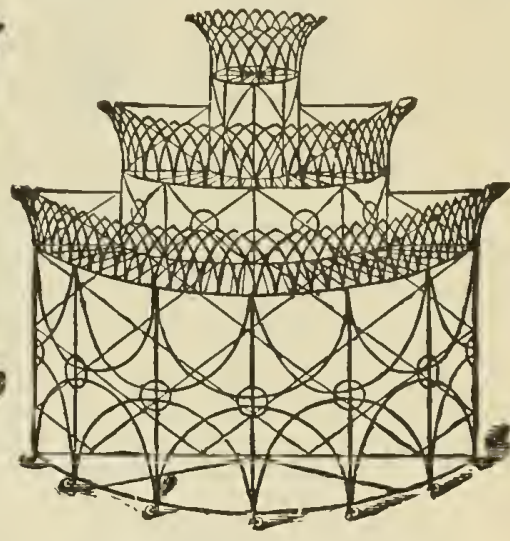

No. $4, \$ 4.75$.

Semicircle Stand, 36 in. high, 26 in. deep.

No. 3 is like No. 2, but has 3 shelves, 36 in. high, 24 in. deep, 33 in. long. $\$ 4 . \infty$.

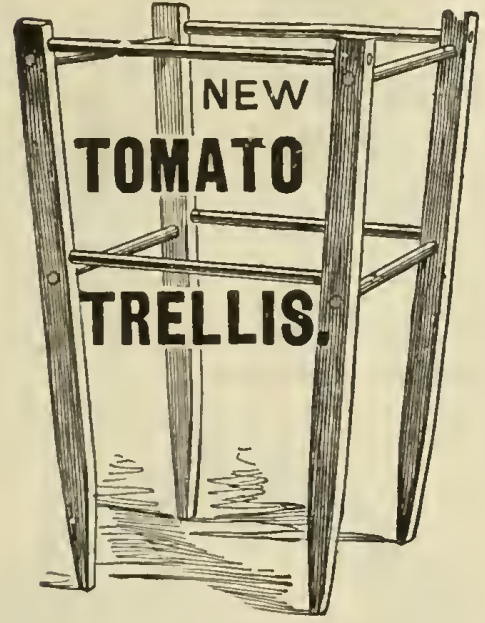

R()UND.

PATENT FOLDING WIRE PLANT STANDS.

Two and three shelf. Painted green, bronzed, and with strong casters. Frame folds perfectly flat to the thickness of two wires The shelves detach and fold one within the other. Size of two-shelf, 31 inches high, 18 inches deep, 36 inches long or wide. Price, $\$ 3.25$ each. Size of three-shelf, 39 inches high, $19 \frac{1}{2}$ inches deep. 29 inches long or wide. Price, $\$ 4.00$ each.

\section{NEW TOMATO TRELLIS.}

Try them once. Tcmatoes all clean and off the ground wil ripen earlier. Height, two and one half feet. One and one hal feet square at top, one foot at bottom. Weight, five pounds each. Per doz., only \$2.00.

\section{PLANT STICKS.}

Square and round, tapering and painted green; the neates: plant stick for supporting frail plants, the larger sizes being also suitable for Gladiolus, Dahlias, etc.

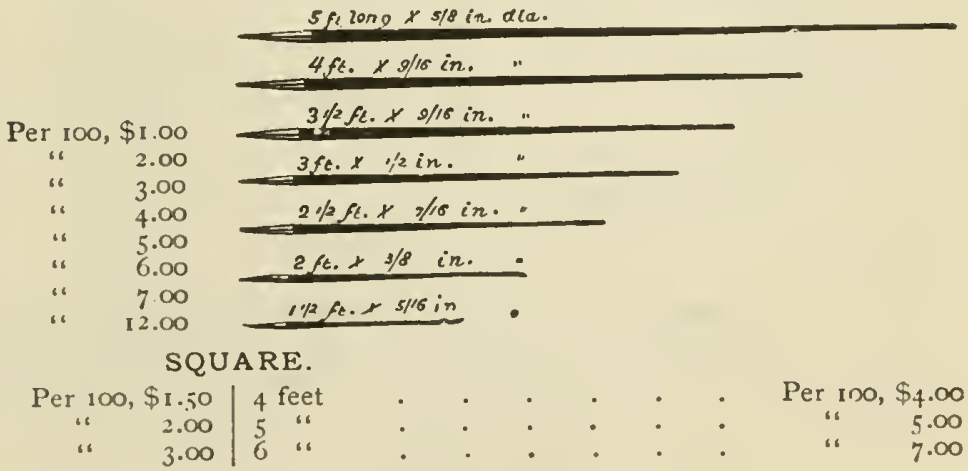

CEDAR PLANT TUBS.

For growing $A$ gaves, Century, and other large plants. Made of the best red cedar; painted green : iron handles.

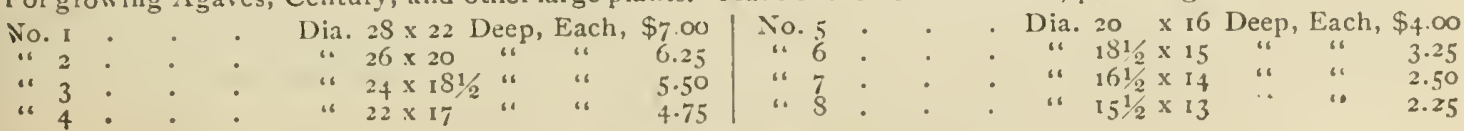

See Special Offers on third page of cover. 


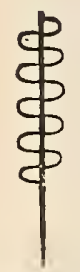

No. oo.

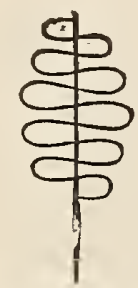

No. oo wide.

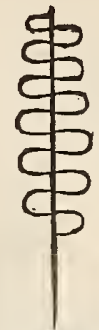

No. o.

No. $\infty$, 18 -in. stick, $3 \frac{1}{2}$ in. wide

" $\infty$ wide, 20-in. stick, 8 in wide

"o, 24-in. stick, 5 in. wide

" o wide, 24-in. stick, 8 in. wide .

o1/2, 24-in. stick, $71 / 2$ in. wide

Ivy Trellis. -16 in. diameter
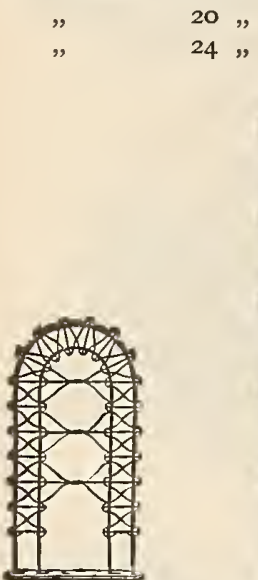

4 "

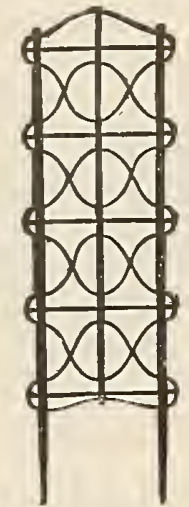

Arch Top Ivy.

Veranda Trellis.

ARCH TOP IVY.

$28 \times 14$ in., black walnut base

BOW TRELLIS.

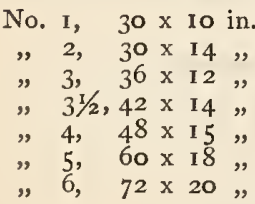

CROSS TRELLIS.

$24 \times 15 \mathrm{r} / 2$ in. $42 \times 24$

TRELLISES.
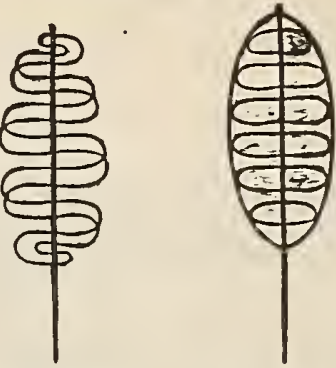

No. $01 / 2$.

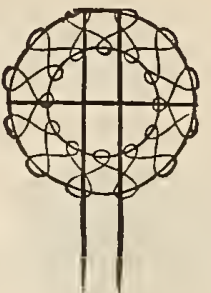

Ivy Trellis.

$\begin{array}{rr}\$ 0.05 & \$ 0.50 \\ .08 & .75 \\ .08 & .75 \\ .10 & 1.00 \\ .15 & 1.50 \\ .50 & 5.00 \\ .60 & 7.00 \\ .75 & 9.00\end{array}$

Fan Trellis. - $1 \mathrm{t} / 2 \mathrm{ft}$, .

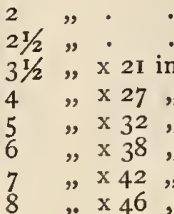

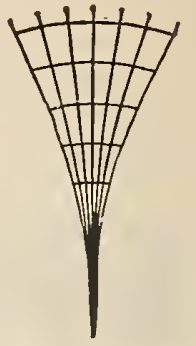

Fan Trellis. Each. Per Doz.

$\$ 0.10 \$ 1.00$

$\begin{array}{ll}.15 & 1.5 \mathrm{C}\end{array}$

$.20 \quad 2.00$

$.50 \quad 5.00$

$.50 \quad 6.00$

$.75 \quad 8.00$

$.75 \quad 9.00$

I. $.00 \quad$ I 1.00 $1.00 \quad 12.00$
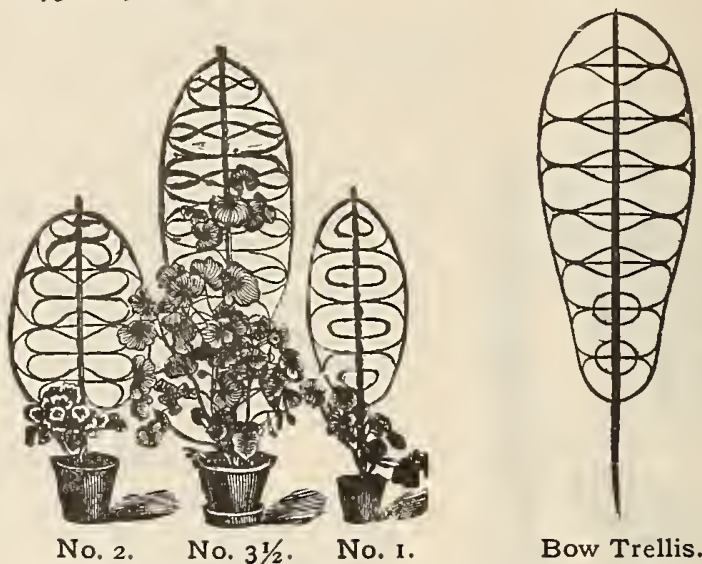

Bow Trellis.

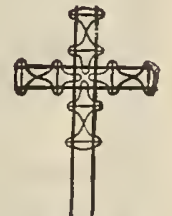

Cross.
VERANDA TRELLIS.

$\begin{array}{rr}\text { Each. } & \text { Per Doz. } \\ \$ 1.00 & \$ 10.00 \\ & \\ \$ 0.20 & \$ 2.00 \\ .30 & 3.50 \\ .40 & 4.00 \\ .45 & 4.50 \\ .50 & 5.00 \\ .60 & 6.50 \\ .75 & 8.00\end{array}$

\section{VERANDA TRELLIS.}

$\begin{array}{rr}\$ 0.30 & \$ 3.00 \\ .40 & 4.50\end{array}$

$\begin{array}{rr}\text { Each. } & \text { Per Doz. } \\ \$ 0.30 & \$ 3.00 \\ .40 & 4.00 \\ .50 & 5.00 \\ .70 & 8.00 \\ .80 & 9.50 \\ .95 & 11.50 \\ 1.10 & 13.00 \\ 1.25 & 15.00 \\ 1.50 & 18.00 \\ 1.75 & 21.00 \\ 2.00 & 24.00\end{array}$

INSECT POWDER BELLOWS (Houchin's Patent).

These possess the following advantages over all other makes: strength, durability, effectiveness, and low cost. They are fitted with patent receivers and are altogether the best bellows in the market. They are made in the following sizes:-

$$
\begin{aligned}
& \text { No. } 11 .+. \quad 4^{1 / 2} \times 16 \text { in. } \\
& \begin{array}{llllllllll}
\Rightarrow & 14 & \cdot & \cdot & \cdot & \cdot & 51 / 2 & x & 20 &
\end{array},
\end{aligned}
$$

BATES' FOLDING PLANT PROTECTOR, for protecting plants from vermin, and from light Spring frosts and high winds. Facilitates the growth of young plants wonderfully. Each, I 5 cents; per doz., \$1.50.

RUBBER PLANT SPRINKLER, an indispensable article for showering plants, sprinkling bouquets, and dampening clothes. Price, large size, \$1.00; small size, 50 cents eāch. 


\section{INSECTICIDES AND GARDEN AND FARM REQUISITES.}

We are Sole New England Agents for W. S. Powell \& Co.'s Reliable Fungicides and Insecticides, and offer the following at the inanufacturer's prices:

Powell's Guicide Powder. For potato blight, potato rot, grape vine flea beetle, potato bugs, pear and cherry slugs, codling inoths, curculio and strawberry crown borers. Can be used either dry or in solution. 25lb. boxes, .06 per lb., \$1.50 per bux

Powell's Copperdine. For black rot, downy mildew, and anthracnose of the grape, pear leaf blight, pear scab, apple scab and powdery mildew. I gallon cans, (makes 100 gallons wash) \$1.50 per can.

Powell's Bordeaux Mixture. For black rot, downy mildew and anthracnose of grapes, potato blight, potato rot, leaf blight of cherry, pear, quince, and other fungus diseases. 20-lb. packages, (50 gallons wash) $\$ 1.00$ per package.

Powell's Kerosene Emulsion. For plant lice of any kind, cabbage worms, scale insects on apple, pear, orange, lemon and other trees. 5 gallon buckets, (makes 75 gallons wash) $\$ 1.25$ per bucket.

Powell's Quassaine. This is a concentrated fluid extract Quassia, held in suspension by Whale Oil Soap adopted and officially recommended by the State Horticultural Board of Washington, as a cheap and eliable non-poisonous insecticide for hop lice, aphis and all scale insects, nothing better tor rose bushes and house plants. Quart cans, (50 gallons wash) \$1.0o per can; I gallon cans, (IOO gallons wash) \$I.50 per can; 2 gallon cans, (200 gallons wash) $\$ 2.50$ per can.

Powell's Carbolized Soap. For peach, apple and other tree borers, also for washing trees to prevent attacks of animals or vermin. I gallon cans, (makes 12 gallons paint) $\$ 1.00$ per can.

Powell's Sulpho-Steatite Powder. For lettuce mildew, powdery and downy mildew of the grape, rose mildew and other fungus diseases affecting plants under glass. $25-1 \mathrm{~b}$. boxes (used as a dust) $8 \mathrm{c}$. per lb.

Baskets, Verbena, adjustable handles. \$2.00 per 100; \$1\$.00 per 1,000 .

Carbolic Purifying Powder, for removing disagreeable, unhealthy odors. Trial pkg., .25; 6-lb. pkg., \$1.oo.

Caps, Hay, Breck's Improved, brown, medicated, complete with ropes and pins, each $.55 ;$ per Ioo, \$50.00.

Caps, Hay, Childs' Patent, water, mildew and vermin proof, complete with strings and pins, each .6o; $\$ 55$ per roo.

Canker Worm Exterminator, (Morrill's Tree Ink,) a sure protection to trees from the ravages of grub and canker worms. Directions with each can.

2-lb. Cans

$3-1 b$.

\begin{tabular}{r|l|}
$\$ 0.30$ & $20-1 b$. Cans \\
.45 & $28-1 b$. \\
.60 & $125-1 b$. Kegs, per lb. \\
1.10 & $460-1 b$. Barrels, “
\end{tabular}

Color, Improved Butter, Wells, Richardson \& Co., imparts the "golden tint of June" to butter at all seasons of the year. Bottles sufficient for $500 \mathrm{lbs} ., .25 ; 1250 \mathrm{lbs} ., .50$.

Color, Hanson's Butter, a universal favorite. In bottles at $2.5 \mathrm{c}$, $50 \mathrm{c}$. and $\$ \mathrm{r} .00$ each.

Cotton Batting, for packing flowers; etc. Per sheet, .o6.

Dalmatian Insect Powder, for destroying Roaches, Ants, Fleas, and all other noxious Insects. Per lb., .40.

Dip, McDougall's Sheep, an effective, non-poisonous preparation for killing vermin on sheep, cattle, and domestic animals. Per quart, .75; $1 / 2$ gallon, $\$ 1.50$; gallon, $\$ 2.50$.

Dusters, Tin, with finely perforated bottoms, for applying Paris green, slug shot, and similar insecticides, $25 \mathrm{c}$. ea. Food for Flowers, Bowker's. The best plant food for house plants, clean and effective. Boxes, $15 \mathrm{c}$. and $25 \mathrm{c}$. ea. Gishurst Compound, for destroying vermin on fruit trees, roses, greenhouse plants, etc. In boxes, $35 \mathrm{c}$. and \$1.00 each

Gun, Excelsior Powder, for insect powders. Price, each, .20; per doz., \$2.oo.

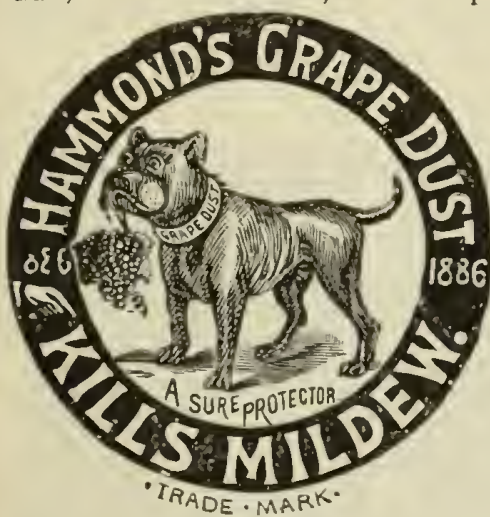

Grape Dust. A preparation for destroying mildew on grape vines. Can also be used on plants or trees affected with mould, mildew, or rust mites, either in greenhouses or the open air. Dust on a warm, dry day. Per lb., 10 cts.; 5 lbs., 35 cts.

Hellebore, for destroying Rose Slugs. One or two applications are usually sufficient for a season, and it is thoroughly effective. With directions. Per lb., $30 \mathrm{cts}$.

Little's Antipest. This preparation is a sure destroyer of all insect pests that infest plants. It is non-poisonous and when diluted and used arcording to directions is perfectly harmless to vegetation. Per pint, 60 cts.; quart, $\$ 1.00 ; 2$ quarts, $\$ 1.50 ;$ gallon, $\$ 2.50$.

London Purple, for destroying potato bugs. Directions with each package. Per lb., 25 cts.

Mats, Archangel. Size, $8 \times 4 \frac{1}{2}$ feet. An excellent covering for frames, hot-beds, etc., $75 \mathrm{cts}$. each.

Mats, Straw, for hot-beds, etc. Each, $6 \times 6 \mathrm{ft} ., \$ 1.75$. Other sizes to order. Oil, Soluble Fir Tree. An invaluable preparation for destroying all insects and parasites that infest fruit trees, plants and animals, whether on the foliage or at the roots of the plants. Does not contain any poisonous properties. Quart, $\$ 1.25 ;$ pint, $.75 ; 1 / 2$ pint, .50.

Paris Green, Breck's Strictly Pure, for destroying potato bugs. It is effectual for destroying that pest. Directions for use with each package. Per lb., 30 .

Paper, Waxed, for packing flowers. Per lb , .50 .

Faper, White, for packing flowers, etc. Per lb., . Io.

Paper, Wrapping, strong manilla. Per lb., .08.

Tarred Paper, for using with tree ink, in rolls, about 5o lbs. each. Per lb., .o5.

Special offer No. 2 only applies to articles on this page. See third page of cover. 
Protector, Arlington Plant, protects from bugs, borers, and fowl; also subdues wind, rain, and cold. Each, I 5 cents; per dozen, \$I.5O.

Protecting Cloth for Hot Beds, largely used as a substitute for glass for protecting plants in early spring. In pieces of about 40 yards, per yard, Io cents.

Scollay's Improved Putty Bulb, for glazing greenhouse sash, etc. Florists and nurserymen have found it to be a very valuable assistant. Price, $\$ \mathbf{r}$.00 each.

Rofiea, a strong and cheap tying material for plants. Per pound, 40 cents.

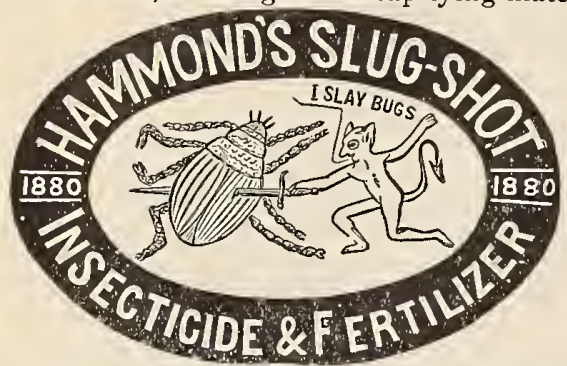

Slug Shot not only acts as an insect destroyer, but it will he found to be an excellent fertilizer. It contains nothing injuriou. to domestic animals, and does not deteriorate by age. On low growing plants it should be dusted on with a very fine sifter. On tall shrubs and trees it should be applied with bellows. Price, $5-1 \mathrm{~b}$ package, 30 cents; Io-lb. package, 50 cents; in barrels of about 226 pounds, four cents per pound.

Soap, Pinner's Tobacco, manufactured from the essential oil of tobacco, for the destruction of all insects, parasites and their eggs Per pound, 50 cents; $1 / 2$ pound, 30 cents.

Soap, Whale Oil, for destroying insects on plants, trees, vines, etc., for washing down the bark of trees. grape-vines, etc. In boxes, I pound, 15 cents; $21 / 2$ pound, 35 cents; in buckets of about 14 pounds, \$I. 75 .

Sulphur, Pure Flour of, for mildew on grape-vines, rose-bushes, etc., and for the destruction of insects on plants. Per pound, ro cents.

Tinfoil, for bouquets (price variable). Per pound, $: 5$ cents.

Tobacco Stems, for fumigating plants to destroy insects. Per pound, ro cents; in bales of about roo pounds, $\$ 2.50$.

Tobacco Dust, kills green and black fly, etc. Can be used dry or to make tobacco water. Per lb., ro cents Twine, Soft, for tying cut flowers, vines, etc. Per ball, 25 cents.

Twine, Parceling, all sizes. Per ball, ro to 2.5 cents.

Wax, Grafting, (Trowbridge's), the best in the market. Put up in $\mathrm{I}-\mathrm{lb} ., 1 / 2-1 \mathrm{~b} .$, and $1 / 4-\mathrm{lb}$. packages. Price per lb., 40 cents ; $1 / 2-1 b ., 25$ cents; $1 / 4-1 b ., 15$ cents.

Wire, Bouquet, Nos. 23 and 24 (price variable). Per stone, \$1.50.

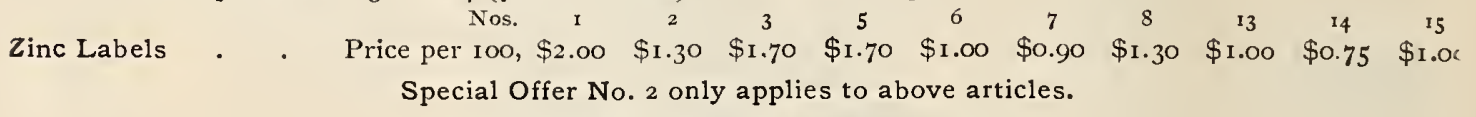

\section{THE MAPES MANURES.}

We are the sole Boston Agents, also, for some other New England sections. Pamphlets giving full information in regard to the Manures mailed free.

These Fertilizers are packed in bags of 200 pounds each. 2.000 pounds to the ton.

Our Special Offers do not apply to Mapes Manures, but we allow five per cent. discount for cash payments. F. O. B. Boston.

Potato Manure. For Irish and sweet potatoes; also for as. paragus, early vegetables, tomatoes, sugar beets, fruits, sor. ghum, and sugar cane. Per bag of $2001 \mathrm{bs} ., \$ 4.50$; three bags and over, $\$ 43.00$ per ton.

Frnit and Vine Manure. For insuring fruiting powcr, particularly in quality of fruit in vineyards (grapes), pears, apples, plums, strawberries, and all small fruits. Is slow in effects. Per bag of $200 \mathrm{lbs} ., \$ 4.20$; three bags and over, $\$$ fo.00 per ton.

Complete Manure (for heavy soils). For use on heavy or clay soil, for wheat, rye, oats, seeding-grass, or spring topdressing of meadows, pastures, etc., on any soils where small quantity of potash but large quantities of amtnonia and phos. phoric acid are required. It is very safe for use around young plants, nursery work, trawberry vines. Is very forcing. Per bag of 200 lbs., $\$ 4.40$; three bags and over, $\$ 4^{2} .00$ per ton.

Complete Manure (for light soils). Early vegetable or truek manure. For all kinds of soils, light or heavy, use broadcast; spccial for onions, also on light soils for as. paragus, sweet potatoes, melons, tomatoes, wheat and seeding to grass. Per bag of 2001 lbs., $\$ 4.60$; three bags and over, $\$ 44.00$ per ton.

Complete Mamure (" $\boldsymbol{\Lambda}$ " Brand). For use in hill or drill on all crops, particularly in connection with farm manures. Specitl for peas, beans, buckwheat, and turnips. Pcr bag of 200 lbs., \$3.90; three bags and over $\$ 37.00$ per ton.

Complete Manure (for general use). A substitute for stable manure. For use on all crops and all souls with or with. out stable manure. Use broadcast; use sparingly, if put in hills. Special for oats, Hungarian grass, vegetables, mclons, tomatoes, and sceding with or without grain. Per bag of 200 lbs., $\$ 4.20$; three bags and over, $\$ 40.00$ per ton.

Corn Mamure. For sweet corn, fodder corn, Iungarian grass, millet, latc turnips, latc cabbagc, and seeding to grass. Per bang of 200 lbs., $\$ 4.30$; three bag's and over, $\$ 41.00$ per ton.

Caulifower and Cabbagre Manure. Ammonia, 5.50 to 6.50 per cetst.; phosphoric acid, 6 to 8 per cent.; actual potash, 8 to 1o per cent. Per bag of 200 lbs., $\$ 4.20$; three bags and over, $\$$ per cent.

Grass and Grain Spring Top Dressiug. Ammonia, 5 to 6 per cent.; phosphoric acid, 7 to 9 per cent, actual potash, 5 to 7 per cent. Per bag of 200 llbs., $\$ 4.30$; three bags and over, $\$ 4$ t.oo per ton.

\section{CHEMICALS.}

Prices Variable. Subject to Change Without Notice.

Sulphate Ammonia, 25 per cent. ammonia,

Nitrate Soda, 95 per cent. purity,

Nuriate Potash, So to 85 per cent. MI. Potash, Sulphate Potash, 50 to 55 per cent. S. Potash, Kainit, 20 to 25 per cent. Sulphate Potash,

Bone Black,

Sulphuric Acid, per Ioo lbs. 


\section{POULTRY SUPPLIES. \\ PRICES SUBJECT TO MARKET CHANGES. \\ BRECK'S POULTRY AND SWINE MEAL.}

The success we met in introducing this meat or animal-matter meal has been quite a surprise to us We knew the article was superior to anything of the kind on the market, but as it was not advertised largely we did not look for the immediate immense demand that resulted. We have received many testimonials, anc are daily receiving orders for it from the most successful poultry raisers of the country. Without doubt th zause of its popularity is its merit It is perfectly sweet and wholesome, being prepared when the material are fresh, and it is guaranteed to keep longer and better than good beef scraps. Its odor is sweet and the Aavor more agreeabie than any other meat or animal meal on the market, hence it is better relished bj poultry and swine, and consequently produces more satisfactory results.

In addition to the pure meat and bone, we have combined in this preparation some of the most potent agents known for the production of eggs, not by stimulating but rather by preventing disease and promoting general good health. Per 100 pounds, $\$ 2.25$; per ton, $\$+2.50$.

Ground Beef Scraps, per roo pounds

Desiccated Fisl,

Animal Meal,

Cracked Poultry Bone, " " "

Ground Chicken Bone, "

Ground Oyster Shells,

$\begin{aligned} \$ 2.50 & \text { Rejected Wheat, per roo pound } \\ 2.00 & \text { Wheat Screenings, " } \\ 2.25 & \text { Buckwheat, per bushel } \\ 300 & \text { Millet for Chickens, “" } \\ 3.00 & \text { Barley, } \\ .75 & \text { Sunflower, }\end{aligned}$

$\$ 2.00$

$1.5 \mathrm{C}$

$1 . \infty$

I. 25

1.00

$3.0 n$

\section{BRECK'S EUREKA EGG FOOD.}

For all kinds of laving fowls and voung poultry. Will make your hens lay summer and winter; support. them during moulting, and keeps the fowls in the best condition; prevents and cures the common ailments, such as cholera, gapes, and roup. One-pound pkg., $25 \mathrm{cts}$; $212-1 \mathrm{~b}$. pkg., $50 \mathrm{cts} . ; 6-1 \mathrm{~b}$. box, \$1.00; 10-1b. box, \$I.50 $25 \cdot \mathrm{lb}$. keg, $\$ 3.25$.

We are the New England Agents for Havens' Condition Powders and Rust's Egg Producer. Special Prices to the trade. RUST'S EGG PRODUCER.

Although moderate in price, Rust's Egg Producer is not too cheap to be the best Egg Food in existence, and it is of such concentrated strength it can be used every day at a cost of from one to two cents for each fowl, according to the size purchased. Prices: I.lb. pkg., $25 \mathrm{cts}$; 21/2-1b. box, $50 \mathrm{cts}$; 6-1b. box, \$1.00; 10-lb. box, \$1.50; $25 \cdot 1 \mathrm{~b}$. $\mathrm{keg}, \$ 3 \cdot 50$

\section{RUST'S HAVENS' CLIMAX CCNDITION POWDER.}

The only positive preventive and cure for gapes and poultry cholera and the best medicine for horses, cattle, poultry, sheep, and hogs. Price, liberal packages, $25 \mathrm{cts}$; 5 -lb. box (net weight and zqual to six small-size packages), \$r.oo. The dollar size is the favorite with farmers, livery-stable keepers, poultry-fanciers, stockjwners, etc.

RUST'S HAVENS' ROUP PILLS. Forty-eight pills in a box. Per box, 25 cts., mailed.

Special Offer No. 2 only applies on above goods.
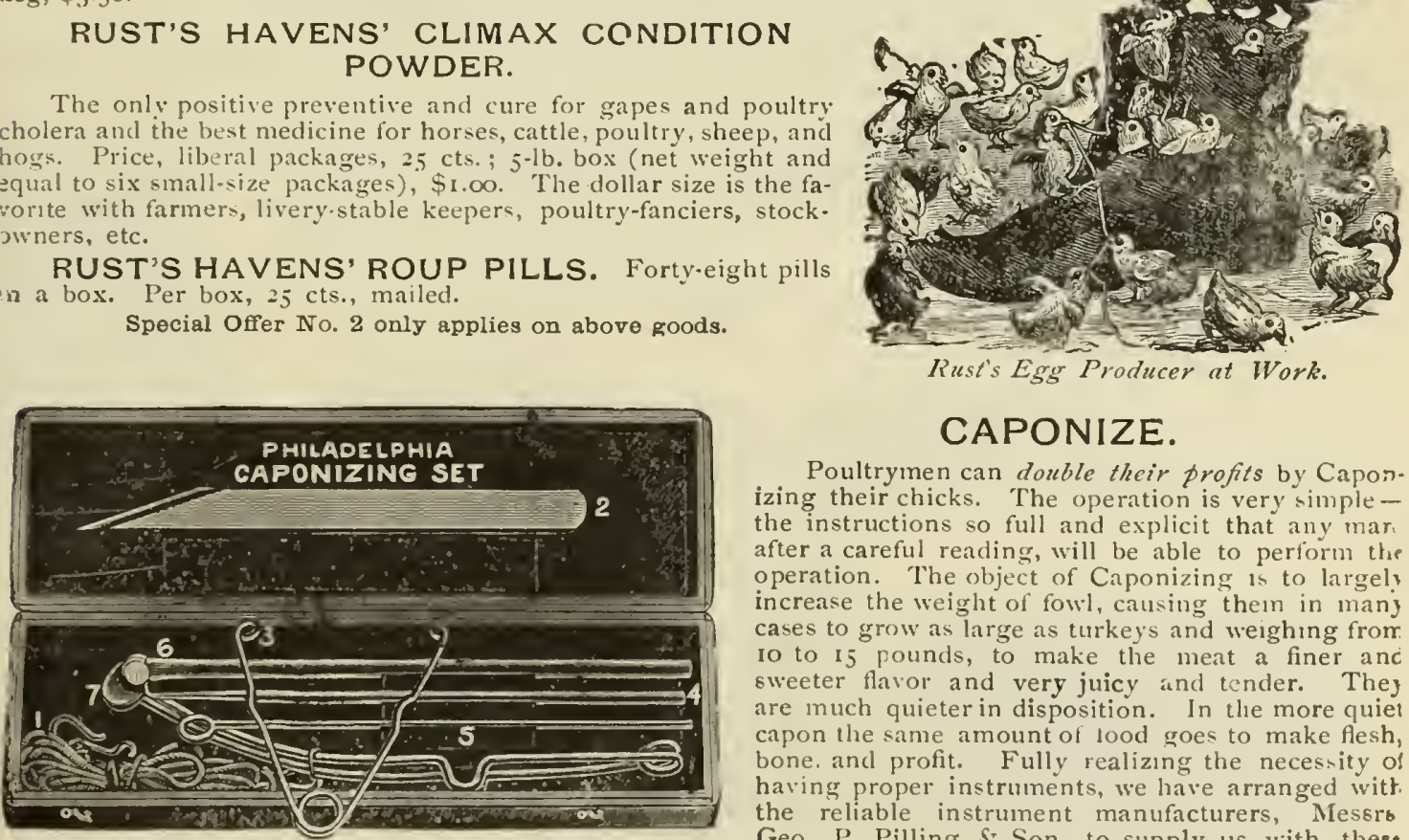

\section{CAPONIZE.}

Poultrymen can double their profits by Caponizing their chicks. The operation is very simplethe instructions so full and explicit that any mar. after a careful reading, will be able to perform the operation. The object of Caponizing is to largels increase the weight of fowl, causing thein in many cases to grow as large as turkeys and weighing from: Io to 15 pounds, to make the meat a finer anc sweeter flavol and very juicy and tender. They are much quieter in disposition. In the more quie capon the same amount of lood goes to make flesh, bone, and profit. Fully realizing the necessity of having proper instruments, we have arranged witt. the reliable instrument manufacturers, Messrb Geo. P. Pilling \& Son, to supply us with these instruments.

Complete with instructions, \$2.50. In velvet-lined case, as per engraving, $\mathbf{\$ 2 . 7 5 .}$

We send book, "CoMplete Glide for CAPOxizixg," with every set.

See Special Offers on third page of cover. 


\section{FERTILIZERS. \\ BRECK'S LAWN AND GARDEN DRESSING.}

The verdict of all who have used Breck's Lawn and Garden Dressing is that it is the most complete and satisfactory Lawn Dressiag ever placed upon the market. It is a brand manufactured expressly for our own trade, and we can therefor vouch for its containing all the constituents required to produce a growth of grass of a luxuriant nature and rich green color. While many Lawn Dressings are claimed to be odorless, we believe beyond a question that ours is the only absolutely odorless. It is also so clean that the most fastidious person can apply it without offending the organs of sight and smell. It being quick in action, the effect can be seen immediately after the first rain or the sprinkling of the hose, and going directly to the roots of the grass, stimulates them to greater activity, thereby thickening the sward and producing a firmer growth, which remains rich, green and velvety throughout the season. Its superiority over stable manure can scarcely be estimated, as the l.tter, in addition to disfiguring the lawn by its unsightly appearance, also gives out an unpleasant odor, and always contains weeds and other undesirable seeds. Great care should be taken to distribute the dressing evenly, and in no greater quantities than recommended on the tag which accompanies each bag, as a too liberal application will injure the sward. It can be applied at any time during the year from April to November, as often as the grass seems to need nourishment. In making new lawns apply at the same time the seed is sown and rake in with the seed. Never apply the dressing while the grass is wet with dew or rain. Any time the grass is perfectly dry will answer, but the best time to apply it is just before a shower. It is equally as suitable for flowerbeds and all vegetable crops as for the lawn.

FOR LAWNS.

Trial bags for I, Ooo square feet . . \$0.50

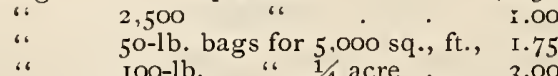
، IOO-lb.
I. 75
FOR FLOWER BEDS AND THE KITCHEN GARDEN.

25 -lb. bags for 600 square feet . . \$I.00

5o-lb. " " 1,200 "

IOo-lb. " " 2,500 " . 3.00

200-lb. “ $1 / 8$ acre “

\section{STURTEVANT'S GRANULATED TOBACCO AND SULPHUR. LAWN DRESSING AND GARDEN FERTILIZER.}

We are the manufacturers' New England agents for this valuable, combined Fertilizer and Insecticide. This is a cheap, odorless and easily applied Fertilizer, valuable alike for the flower and vegetable garden, orchard and lawn. It prevents the ravages of worms on the lawn, and tends to keep plants free from insects. It should be used at the rate of $5^{\circ}$ lbs. per 1,000 square feet. Price, for Ioo-lb. bag, \$2.50, per $5^{\circ}-1 b$. bag, \$I.50, per 25 -lb. bag, \$I.oo.

\section{FLOUR OF TOBACCO AND SULPHUR.}

\section{Special Offer No. 2 only applies to this article.}

A desirable Fertilizer for house plants. May be applied in powder or liquid form. It prevents mildew on grapes and rose bushes, and destroys the green and black fly, grubs, cutworms, lice, etc. Packages 25 and 50 cents each.

\section{PERUVIAN GUANO.}

For forcing early vegetables or second garden crops, the brand "No. I Guaranteed," Peruvian Guano, is especially recommended. It is generally used by florists, and nothing is better for house plants than a weak solution applied once or twice a week.

PRICE : Per ton in 200-lb. bags

$$
\begin{aligned}
& \text { " } 200-1 \mathrm{~b} \text { bag } \\
& \text { " Ioo-lb. bag } \text { I-lb. package }
\end{aligned}
$$

\} $\left.\begin{array}{c}\text { Net, F. O. B. } \\ \text { Boston. }\end{array}\right\}$

\section{UNLEACHED HARD-WOOD ASHES.}

We can supply direct from one of the most careful collectors in Canada, Unleached Hard-wood Ashes. Price on carload lots delivered at any point upon application.

PRICE : Per ton, in barrels . . \} Special offer No. 2 only

Per barrel . . . $\quad$.

$\$ 18.00$ 2.00

\section{SHEEP MANURE.}

The superior of all natural manures. Better than any chemical fertilizer. This is a pure natural manure, and the most nutritious food for plants. Its effect is immediate. It is the best of all manures for mixing with the soil for green-house plants-one part manure and six parts soil. Strewn over and dug into the vegetable garden, or placed directly in drills or hills, it promotes a rapid, steady growth until maturity. It makes the richest, safest and quickest liquid manure, rivalling guano, without any deleterious effects. For use in liquid form, one pound to tive gallons of water will make a dark liquid which can be used with safety daily if necessary. Retail price, in bags of Ioo lbs. each, $\$ 3.50 ; 1 / 4$ ton, five bags, $\$ 15.00$; per ton, 20 bags, $\$ 4.5 .00$. Sheep manure at ton price is net F. O. B. Boston; smaller quantities as quoted are subject to Special Offer No. 2 only.

\section{PLASTER DUST.}

For destroying insects upon vines. Per 5-lb. box, I5c.; 25-lb. bag, 50c.; barrels of about 150 lbs., $\$ 2.00$ per barrel. Net F. O.B., Boston. 


\section{Bradieso

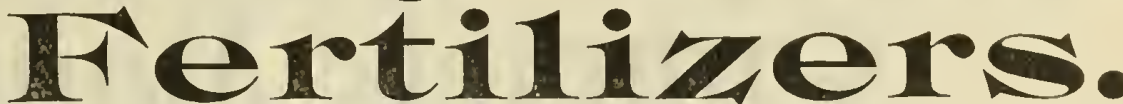

The Bralley Fertilizer Company are the largest fortilizer manufucturers in the world. Their flant and equifment are unsurpassed in extent, completeness, and adapiability for making the highest grades of fertilizers.-Boston Cultivator.

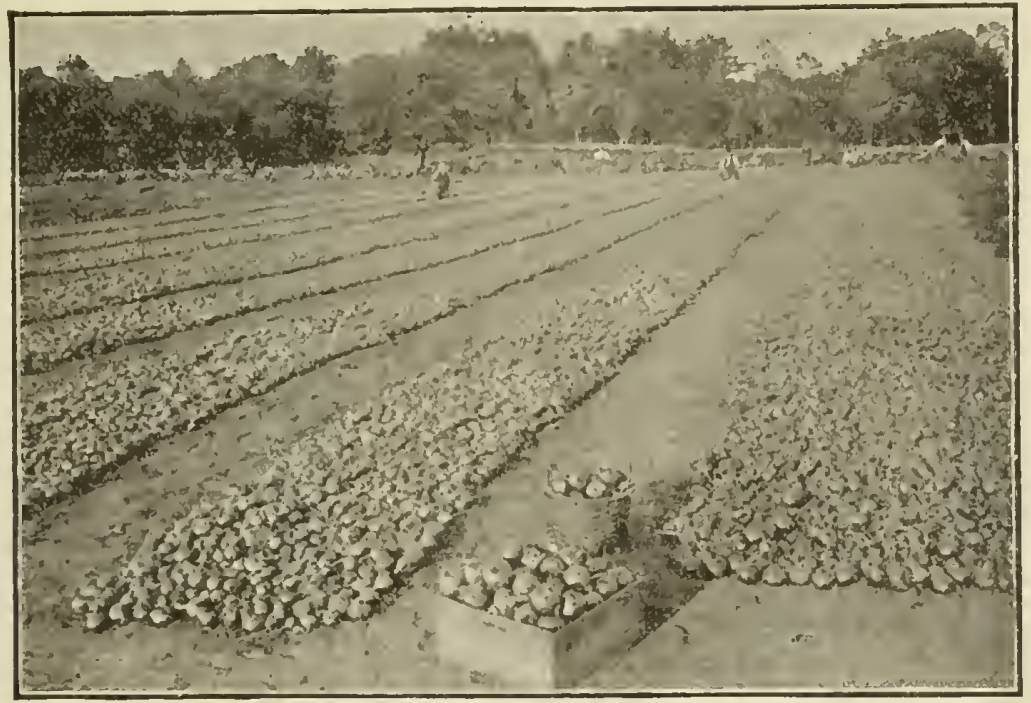

I give you, with pleasure, an account of my remarkable onion crop. The land being first dressed with stable manure, I,600 llbs. of Bradley's Complete Manure to the acre was aptilied. At harvest the land was surveyed, the onions accurately measured, and the exact yield found to be $1,0 S_{2}$ bushels of fine onions to the acre. A well-known seedgrower has expressed his opinion that mine was the largest crop of onions ever produced in Essex County.

Danvers, MAss., October, $1 \$ 93$.

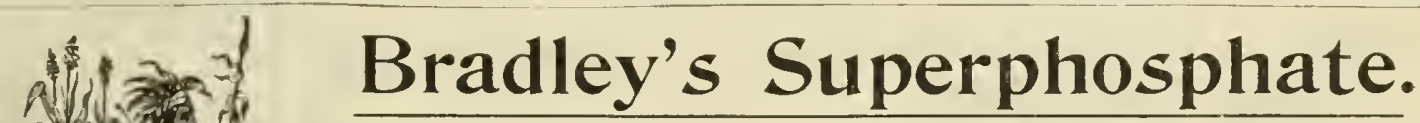

A High-Grade Complete Fertilizer for all Farm and Garden Crops.

Bradley's Superphosphate, the pioneer of the fertilizer industry in the United States, has been more extensively used than any other brand of fertilizer in the world.

From its unvarying quality and uniform condition it has gained the name that more plainly bespeaks the estimate in which it is held among the farmers than volumes of praise - " the Old Reliable."

To the constant attention paid to the selection and preparation of the materials used in its manufacture is due the enviable reputation it has so long maintained for superior crop-producing powers and unequalled mechanical condition.

As it is a complete fertilizer, rich in available phosphoric acid, ammonia, and potash, it can be used either with or without barnyard manure.

\section{BRADLEY'S POTATO MANURE.}

\section{For Growing Smooth, Sound Potatoes of the Best Quality Without Barnyard Manure.}

Bradley's Potato Manure is in no sense a theoretical or experimental mixture, but is prepared from formulas which repeated field tests have proven will produce the largest crops of smooth, sound potatoes.

The universal testimony of leading farmers is convincing that it gives the best of satisfaction, and at a considerable saving in cost over many of the highpriced "special potato manures" whose alleged scientific combination is their principal claim to the farmer's patronage.

I will tell you how I raised that bushel of sixty "White Elephant" potatoes. and well harrowed. I used five hundred pounds of Bradley's Potato Ilanure per acre, putting one spoonful in each hill, and the potatoes averaged about twenry hills to the bushel.

1 attribute my great yield of potatoes in vour Potato Mlanure, and shall use a much larger amount in the future. I heartily commend Iradley's Fertilizers to all interested in farming.
TILTON, N. H., Dec. 7, 1893 . J. DLIS.

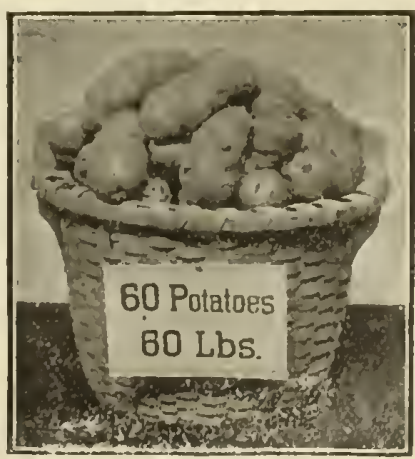




\section{Bradley's \\ Complete Manures.}

These manures are the richest and most concentrated fertilizers sold, as has been abundantly proven by actual results in the field. They are manufactured from the very best plant-food materials obtainable, combined in such forms and proportions as long practical experience has proven will yield the largest crops of the best quality. In mechanical condition they are unequalled, being fine and dry, and therefore drill perfectly in any machine.

They are divided into three classes, based upon exhaustive field tests and not upon theoretical experiments of the laboratory, the fault of "Special Crop Fertilizers" in which common sense and practical experience are sacrificed for the sake of theoretical "hobbies."

Bradley's Complete Manures are in the fullest sense "complete" fertilizers, and the three grades furnish complete plant food in the best forms for all crops grown.

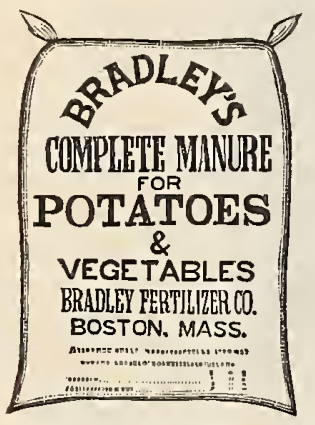

\section{Bradley's Complete Manure for Potatoes and Vegetables}

Is particularly rich in ammonia and potash, and has given phenomenal results in growing large crops of the best quality of potatoes, onions, beets, turnips, carrots, cabbages, squashes, melons, etc. It is a perfect fertilizer for growing all kinds of root crops and market garden truck. It is the market gardener's favorite.

\section{Bradley's Complete Manure for Corn and Grain, \\ Containing a larger percentage of available phosphoric} acid, but with less potash than the brand for potatoes and vegetables, is especially recommended for growing large crops of fully matured corn and grain. It has never been equalled by any "special" fertilizer for these crops.

\section{Bradley's Complete Manure for Top=dressing Grass and Grain:}

This fertilizer contains a very large amount of nitrogen in quickly available form, and therefore imparts to grass and grain, when applied as a top-dressing in the early spring, a quick, vigorous start, and insures early maturity. Meadows and pasture lands are wonderfully renewed by an application of 400 to 600 pounds of this fertilizer to the acre in the early spring, the hay crop being oftentimes increased threefold by its use.

THE BRADLEY FERTILIZER CO. manufacture fertilizers of ALL GRADES and FOR ALL CROPS; aud, being the LARGEST MANUFACTURERS IN THE WORLD, their facilities for furnishing all kinds of fertilizers aud agricultural chemicals at the lowest prices are absolutely unequalled.

\section{Prices for Bradley's Standard Fertilizers}

Bradley's Superphosphate

Bradley's Potato Manure

Bradley's Complete Manure for Potatoes and Vegetables

Bradley's Complete Manure for Corn and Grain

Bradley's Complete Manure for Top-Dressing Grass and Grain

Bradley's Bone Fertilizer

Bradley's High Grade Tobacco Manure

Bradley's Seeding-Down Manure 5o-lb. bag, \$I.25

I oo-lb. bag, \$2.00

" $\quad 2.00$

" $\quad 2.25$

" , 2.25

$, \quad, \quad 2.25$

50-lb. bag, \$r.25

" , 2.75

" $\quad$ " 1.75

$$
\begin{array}{cr}
\text { ton, } \$ 36.00 \\
" \quad 36.00 \\
" \quad 42.50 \\
" \quad 42.50 \\
" \quad 42.50 \\
" \quad 35.00 \\
" \quad 50.00 \\
" \quad 30.00
\end{array}
$$

These prices are not subject to special offers, but we allow a discount of 5 per cent. when cash accompanies order. 


\section{Stockbridge \\ THE \\ ORIGINAL \\ Special Fertilizers.

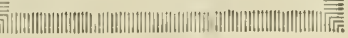

\section{Special \\ Complete}

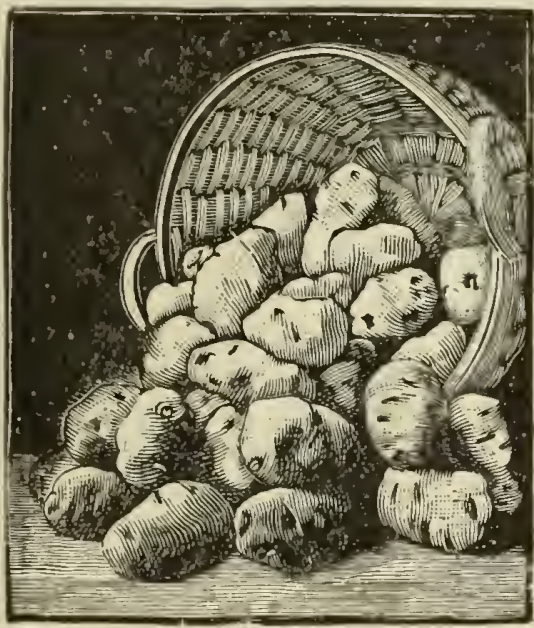

These celebrated fertilizers are special fertilizers made for different crops or classes of crops: they not only go further and cost less per acre, but furnish to growing crops at the right time, in the right forms, and in the right proportions, all the elements they need for perfect maturity.

\section{The Largest 20 Prize Crops}

in the great potato contests for the two years were raised exclusively on Stockbridge Potato Manure alone, no other dressing of any kind being used, and without irrigation.

\section{$\$ 2,084.44$ worth of Celery from 1 acre} was raised on Stockbridge, in Rhode Island, as shown in the Bowker Fertilizer Catalogue, which we send to any address on request.

\section{LIST OF STOCKBRIDGE SPECIAL MANURES.}

Stockbridge Potato Manure, Stockbridge Corn Manure, Stockbridge Grass Manure, Top Dressing,

Stockbridge Seeding Down Manure,

Stockbridge Vegetable Manure,

Stockbridge Fruit Manure,

Stockbridge Root Manure,

Stockbridge Asparagus Manure,

Stockbridge Celery Manure,

* The above quantities recommended for one acre are without stable manure; but, if stable manure is used in con. nection with the Stockbridge, then a smaller anount can be used, depending on the amount of manure applied and its richness. About one-half the quantity of each is the rule.

The first column gives the usual quantities which farmers apply, and the second column the usual quantities which market gardeners apply.

\section{BOWKER'S HILL AND DRILL PHOSPHATE.}

The prices quoted on "Stockbridge Manures," Bowker's "Hill and Drill," and "Fresh Ground Bone," are net f.o.b. Boston, and not subject to our special offers; but a discount of five per cent. may be deducted when cash accompanies order.

A rich and concentrated general fertilizer for all crops, used alone or with manure. It is made to act through all the season, not only at the beginning, but at the end, and for this reason has met with great success.

PRICE : Per 50-lb. bag,

$$
\text { PrICE: Perton, . \$I.25 PrICE: Per I00-lb. bag. } \$ 36.00
$$

$\$ 2.00$

This bone contains not only the glue, but all the properties of Fresh Raw Bone, being dried and ground within twelve hours after the animals are slaughtered. It may not look so white as weather-bleached or glueless bone, but it is really worth from $\$ 4.00$ to $\$ \$ .00$ a ton more.

Per 50-1b. bag,

$\$ 1.25 \mid$ Per roo-lb. bag, 


\section{VALUABLE TABLES.}

SEED REQUISITE TO PRODUCE A GIVEN NUMBER OF PLANTS AND SOW AN ACRE.

Artichoke, I oz. to 500 plants Asparagus, I oz. to 200 plants Barley Beans, Diwarf, I qt. to i 50 feet of drill Beans, Pole, I qt. to 200 hills Beet, Garden, I oz. to Ioo feet of drill. Beet, Mangel, I oz. to I 50 feet of drill. Broccoli, I oz. to 3,000 plants Broom Corn .

Brussels, Sprouts, I oz. to 3,000 plants Buck wheat

Cabbage, I oz. to 3,000 plants

Carrot, I oz. to I 50 feet of drill

Cauliflower, I oz. to 3,000 plants

Celery, I oz. to Io,00o plants

Clover, Alsike and White Dutch . Lucerne, Large Red and Crimson Trefoil 8 Medium

Collards, I oz. to 2,500 plants Corn, Sweet, I qt. to 500 hills

Cress, I oz. to I 50 feet of drill

Cucumber, I oz. to 80 hills

Egg Plant I oz. to 2,000 plants

Endive, I oz. to 300 feet of drill

Flax, broadcast

Garlic, bulbs, I lb. to Io feet of drill

Gourd, I Oz. to 25 hills .

Grass, Blue, Kentucky .

$$
\begin{aligned}
& \text { "Blue, English } \text { "Hungarian and Millet } \\
& \text { " } \\
& \text { Mixed Lawn } \\
& \text { Orchard, Perennial Rye, Red Top, Fowl } \\
& \text { Meadow and Wood Meadow }
\end{aligned}
$$

Quantity per acre.

Hemp

Kale, I oz. to 3,000 plants

Kohl Rabi, I oz. to 200 feet of drill

Leek, I Oz, to 250 feet of drill

Lettuce, I Oz. to 250 feet of drill .

Martynia, I oz. to 50 feet of drill .

Melon, Musk, I oz. to Ioo hills

Water, I oz. to 25 hills

Nasturtium, I oz. to 50 feet of drill

Oats

Okra, I oz. to 50 feet of drill

Onion Seed, I Oz. to 2 co feet of drill for Sets

Onion Sets, I qt. to 20 feet of drill

Parsnip, I oz. to 250 feet of drill

Parsley, I oz. to 250 feet of drill

Peas, Garden, I qt. to I 50 feet of drill

" Field

Pepper, I oz. to I, 500 plants

Potatoes

Pumpkin, I qt. to 3 oo hills

Radish, I oz. to I 50 feet of drill

Rye

Salsify, I oz. to 60 feet of drill

Spinach, I oz. to $I_{50}$ feet of drill

Summer Savory, $1 \mathrm{oz}$. to 500 feet. of drill

Squash, Summer, I oz. to 40 hills

" Winter, I oz. to Io hills.

Tomato, I oz. to 3,000 plants

Tobacco, 1 oz. to 5,000 plants

Turnip, I oz. to 250 feet of drill

Vetches

Wheat
Quantity per acre.

- I bu.

4 oz.

2 lbs.

4 " 4

3

10

$13 / 4 "$

$11 / 2 "$

Io bu.

$2 \frac{1}{2}$ "

Io lbs.

.4 to 5 "

30 to 50 "

8 bu.

$5 \mathrm{lbs}$.

I $1 / 2$ bu.

$21 / 2$ "

4 oz

ro bu.

8 lbs

I $1 / 2 \mathrm{bu}$.

$8^{1 / 2}$ Ibs

IO "

24

2 "

3 oz

${ }^{2} 1 / 2$ "

3 bu

- I to 2 "
4 Timothy

\section{NUMBER OF}

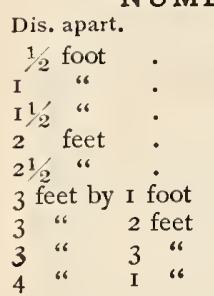

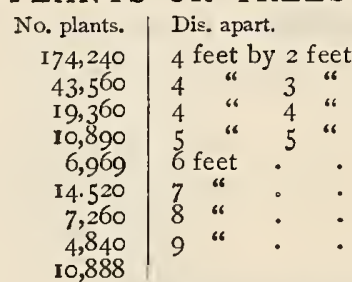

\begin{tabular}{|c|c|c|c|c|c|c|c|c|c|c|c|c|c|c|c|c|c|c|}
\hline Apples . & & • & - & - & & Per bush., & 48 & lbs. & Onions . & - & • & - & - & & Per & bush & 1., $52 \mathrm{lbs}$ & lbs. \\
\hline “ Dried & - & - & - & & - & “ & 22 & “ & Peas $\cdot$. & . & . & - & . & - & & & 60 " & “ \\
\hline Barley . & . & . & . & - & - & $" 6$ & $4^{8}$ & " & Flastering Hair & . & . & . & - & . & & & 8 & " \\
\hline Beans & . & . & . & • & & “ & 60 & “. & Rape • • & - & - & . & - & . & & “" & 50 & \\
\hline Buckwheat & & . & - & - & & “ & 48 & “ & Rye $\cdot$. & - & . & . & . & . & & “ & 56 & - \\
\hline Broom Corn & & . & . & • & & " & 46 & “ & *Red Top Seed & . & . & . & . & . & & & $\mathrm{I}_{4}$ & : \\
\hline Blue Grass, $\mathrm{K}$ & Kentı & ucky & . & . & & “ & I4 & “ & Salt, Coarse . & - & . & - & - & . & & " & 50 & " \\
\hline " $\quad$ " 1 & Engli & & . & • & & “ & 24 & “ & " Michigan & . & . & . & . & - & & “" & 56 & “ \\
\hline Bran & . & . & . & & & $\%$ & 20 & “6 & Sweet Potatoes & . & . & . & . & . & & “ & $5^{6}$ & “ \\
\hline Canary Seed & & . & . & & & “ & 60 & “ & Timothy Seed & . & - & - & - & - & & “ & 45 & “ \\
\hline Castor Beans & & . & - & • & & “ & 46 & $" 6$ & Turnips & . & . & . & & . & & “ & $5^{8}$ & “ \\
\hline Clover Seed & & . & . & • & - & “ & 60 & “" & Wheat : & & & . & . & . & & “ & 60 & " \\
\hline Corn, Shelled & & . & . & • & & “ & $5^{6}$ & $"$ & Beef and Pork, pe & er bbl. & ., net & & - & - & & & 200 & 16 \\
\hline " on Ear & & • & - & - & • & “ & 70 & “ & Flour, per bbl., n & & & & & . & • & & 196 & \\
\hline Corn Meal & . & . & . & • & & “" & 50 & “ & White Fish and 1 & Trout, & per $\mathrm{b}$ & bbl., I & net & . & . & & 200 & \\
\hline Charcoal & & . & . & - & & “ & 22 & “ & Salt, per bbl. & . & . & . & . & - & & . & 280 & “ \\
\hline Coal, Minera & & . & . & - & & “ & 80 & “ & Lime, " & & & & - & - & . & - & 220 & $\because$ \\
\hline Cranberries & & . & . & • & & “" & 40 & “ & Hay, well settled, & , per $\mathrm{c}$ & cubic & foot & - & - & . & & $41 / 2$ & "“ \\
\hline Dried Peache & & . & - & & & “ & 28 & “ & Corn, on $\mathrm{Cob}_{2}$ in & Lin, & “ & & - & . & - & & 22 & " \\
\hline Flax Seed & . & . & . & • & • & “ & $5^{6}$ & “" & "Shelled, & & " & & - & - & - & & 45 & " \\
\hline Hemp Seed & & . & . & - & & “ & 40 & “ & Wheat, & “ & $"$ & & - & & . & & $4^{8}$ & " \\
\hline Hungarian $\mathrm{G}$ & rass & Seed & • $\quad \cdot$ & & & “ & 48 & $" 6$ & Oats, & “ & “ & & - & & • & & $251 / 2$ & " \\
\hline Irish Potatoe & s, he & aping & measure & . & & " & 60 & “" & Potatoes, & " & " & & & & - & & $381 / 2$ & $2 " “$ \\
\hline Miliet • & . & . & - & - & & " & 50 & 6 & Sand, Dry, & & “ & & - & & - & & 95 & $"$ \\
\hline Malt & . & - & - & & & “ & $3^{8}$ & “" & Clay, Compact, & & " & & - & & & & I 35 & " \\
\hline Oats & & - & . & • & & “ & $3^{2}$ & "“ & Marble, & & “ & & & & & & 160 & “ \\
\hline Osage Orang & & · & - & & & “6 & 33 & “ & $\begin{array}{l}\text { Seatsoned Beech } \\
\text { “ Hickor }\end{array}$ & Wood, & & cord & $\cdot$ & & & & 5,616 & “ \\
\hline Orchard Gras & & & & & & & & & “ Hickor & & & & & & & & & \\
\hline
\end{tabular}

THE ACRE AT GIVEN DISTANCES.

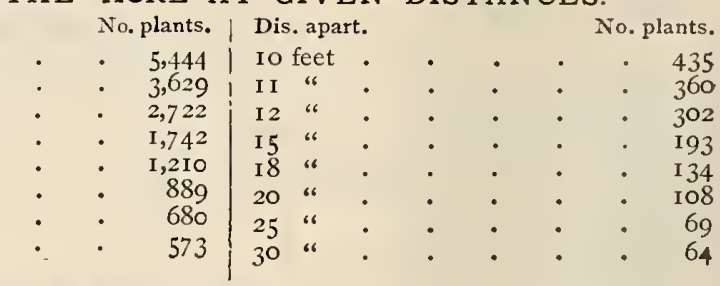

\section{WEIGHT OF VARIOUS ARTICLES.}

* In New England, Red Top is sold at ro lbs. per bushel, so we are obliged to conform and buy and sell at ro lbs. 


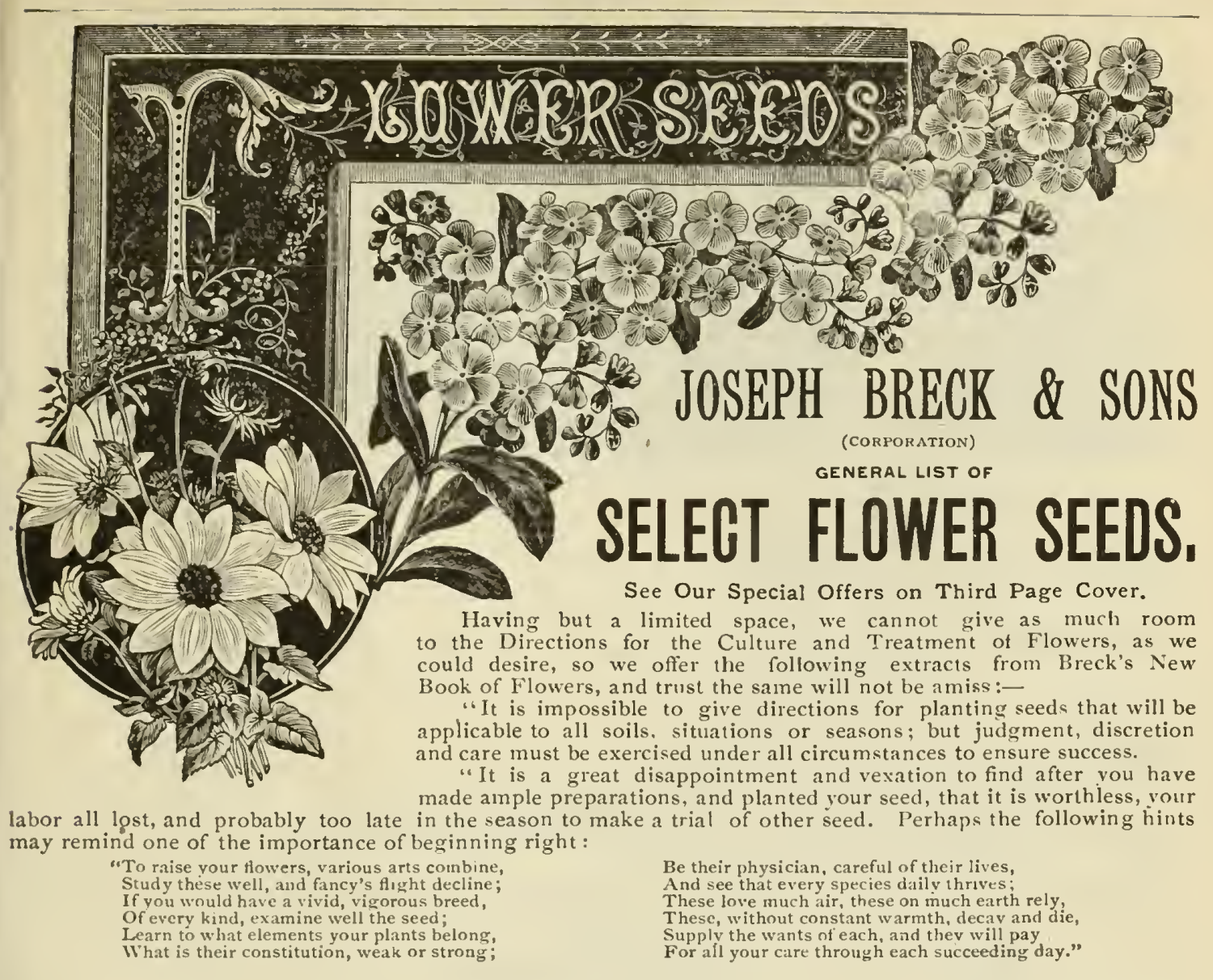

\section{EXPLANATORY.}

Our General List of Flower Seeds, it will be found, is divided into the following groups, viz Annuals, Perennials and Biennials; Climbers; Greenhouse Plants; Everlastings; Ornamenta Grasses, etc. The botanical and common names are arranged in alphabetical order and a very com plete index will be found in the front of book. Following the botanical name is a brief description of the plant, its color, habits, etc. In the first column at the right, the hardiness and duration is given; in the second column, the height of plant; in the third column, the price of seed per ounce, and in the fourth column the price of seed per packet. To this arrangement and the following abbreviations we have given the most careful attention, and we trust that its simplicity will not only find favor with our customers, but prove valuable to them as a handy reference to be used in all matters pertaining to floriculture.

\section{KEY TO ABBREVIATIONS.}

A designates Annuals - Lasting but one year.

Biennials - Lasting two years.

Perennials - Lasting three or more years.

This sign, where affixed to B or P, indicates Biennials or Perennials which, if sown early, flower the first season.

$n$ A designates Hardy Annuals - Seed may be sown in early spring or late in fall.

abA " Half Hardy Annuals - Seed should be sown about middle or last of May.

iA “ Tender Annuals - Seed must be started in artificial heat and transplantea to open ground about June 1st.

hB or hP designates Hardy Biennials or Perennials - Plants stand the coldest winter without protection.

hhB or hhP "Half Härdy Biennials or Perennials - Plants requiring to be well protected during winter.

c1. " Tender Perennials - Plants requiring greenhouse protection during winter.

Hard. and Dur. signifies Hardiness and Duration; Trai., Trailing, H'g't, Height; and Var., Varwous.

Descriptions of New and Special Varietles will be found on colored pages. 
ABOBRA. See Climbers,

ABRONIA. Charming Trailer, with beautiful Verlsena-like flowers.

“ Umbellata, rosy Lilac, fragrant

A renaria, yellow .

ABUTILON. See Seeds for Greenhouse,

ABYSSINIAN GRASS. See Omamental Grasses,

ACONITUM. (Monkshood.) Showy plants, adapted to shady situations.

Napellus, blue, tipped with white

ACROCLINIUM. See Everlastings,

ADLUMIA. (Alleghany Vine.) See Climbers,

ADONIS. Showy border-plants, remaining a long time in flower.

" Estivalis, scarlet

"Autumnalis, crimson

AFRICAN ROSE. See Hibiscus.

AGERATUM. Valuable for beds or borders, in bloom the whole summer; good for winter blooming, and useful for cut flowers.

Lasseauxii, rose
"
"
" Mexicanum, lavender blue
"
" Imperial Dwarf, blue .

AGROSTEMMA. Free-flowering and attractive.

Coli Rosea (Rose of Heaven), rose

" "Alba, white.

" Coronaria Alba, white (Rose Campion), red

AGROSTIS. See Omamental Grasses,

ALLIUM. A showy class of bulbous-rooted plants.

" Azureum, showy heads of azure-blue flowers

Neapolitanum, bearing pure white flowers in an umbel

ALONSOA. One of the most desirable bedding plants, easily grown, flowers all summer.

Myrtifolia, large scarlet flowers, very fine

Warcewiczii, scarlet, good spike

tLYSSUM. Free-flowering, pretty little plants for beds, edgings, or rock-work, $\dot{c}$ r winter-blooming; the annual variety blooms all summer.

Maritimum (Sweet Alyssum), fragrant, white

Benthami Compactum, pure white, dwarf, compact growth

Saxatile

(Gold Dust), deep golden yeliow

Wierzbecki, white and yellow, mixed

AMARANTHUS. Ornamental foliage plants, invaluat fe for bedding purposes.

Bicolor Ruber, foliage green, shaded red, tipped with yellow

Caudatus (Love lies Bleeding), red, drooping panicles of flowers; handsome.

Cruentus (Prince's Feather), crimson, highly ornamental

Henderi, varied colors; very brilliant, one of the best .

Melancholicus ruber, dwarf, compact habit, blood-red foliage

Salicifolius (Fountain Plant), scarlet, bronzy-green foliage, graceful drooping habit.

Tricolor (Joseph's Coat), foliage scarlet, yellow and green, beautiful :

AMMOBIUM. See Climbers,

AMPELOPSIS. See Climbers.

ANA GALLIS. (Pimpernelle.) Valuable for beds, rustic baskets, vases and rock-work; various colors, constant bloomers.

Grandiflora superba, fine mixed

A NCHUSA. A splendid bouquet flower, of long duration. Capensis

ANDROPOGON. See Ornamental Grasses,

ANEMONE. (Wind Flower.) Showy flowering plants, fine for bouquets.

Chinensis, single, mixed .

“ Fulgens, flowers large, bright scarlet

Japonica, red and white mixed

ANGELONIA. Desirable as a pot plant in winter or for outside planting in spring.

Grandiflora, with long spikes of cup-shaped flowers, very fragrant

ANIMATED OATS. See Ornamental Grasses,

ANTHOXANTHUM. See Ornamental Grasses,

ANTIRRHINUM. (Snap-Dragon.) One of the most showy and useful border-plants, with fineshaped flowers of the most beautiful colors.

Majus, tall varieties, splendid mixture

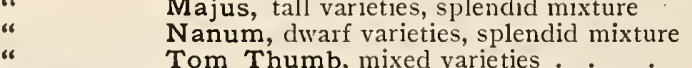

AQUILEGIA. (Columbine.) Produces beautiful, odd-shaped and variously-colored flowers; blooms early in spring.

Californica, hybrida, centre petals golden-yellow, sepals and spurs deep orange red

Chrysantha (golden-spurred), bright golden-yellow

See Special Offers on third page of cover. 


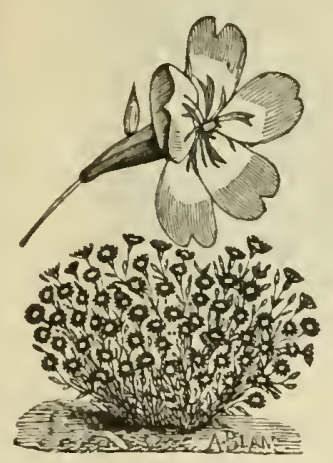

AGROSTEMMA.

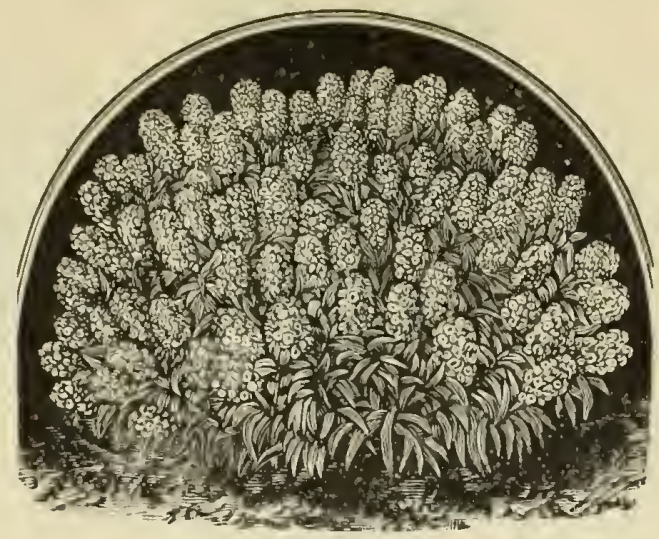

ALYSSUM.

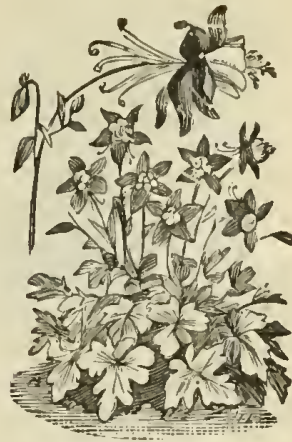

AQUILEGIA.

NAME.

DESCRIPTION

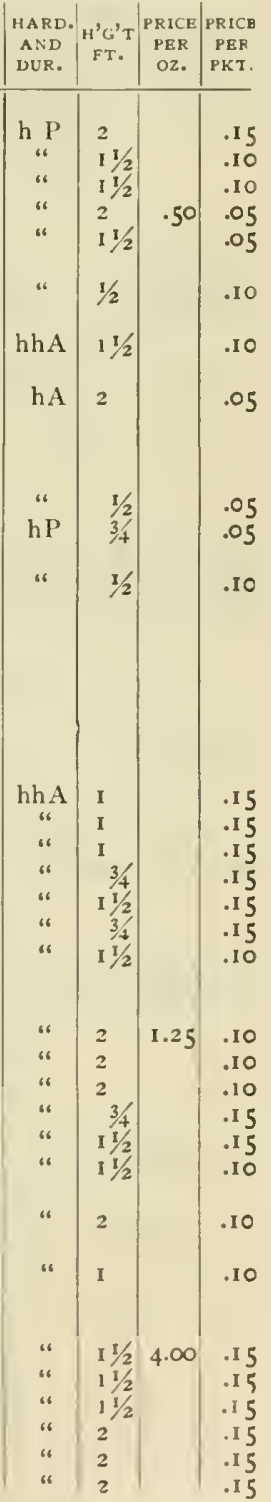

La Superbe, rose, sky-blue and white, pure white; each.

Mixture, of three colors

Corulea hybrida, violet-blue and yellow, fine

Glandulosa, blue-tipped, white

Skinnerii, scarlet and yellow

Single, all colors nixed

Double, mixed

ARABIS. An early-blooming plant, well-adapted for borders and rock work.

Alpina, white

ARCTOTIS. Free-flowering plant, compact, dwarf habit.

Breviscapa, large orange flowers, dark centre

ARGEMONE. (Prickly Poppy.) Large, poppy-like fowers, very effective in the border.

ARISTOLOCHIA. See Climbers,

ARUNDO. Sie Ornamental Grasses,

ASPERULA. Dwarf plants of compact growth, excellent for making bouquets.

Azurea Setosa, blue

Odorata, white, very sweet-scented.

AUBRIETIA. Dwarf-growing plants, invaluable for rock-work and borders.

Græca, blue, charming

ASTER. One of the most popular and effective of our garden favorites, in which richness and variety of color are combined with the most perfect and beautiful form.

The vast improvement made in the last few years by the English and German growers cannot be too highly spoken of. We refer especially to the different varieties of Truffaut's Pxony-flowered and the New Washington Asters. The La Superbe varieties of the first-named are rightly termed, for in every respect they are truly superb.

Comet, pink and white, peculiarly twisted petals

Deep Rose, like preceding, except in color

Prince of Wales, rich dark crimson, fine for fiorists' use

Lilliput, white, small flowers in great abundance

Mignon, beautiful, pure white, habit of the Victoria family.

German Quilled. For beauty and quality of flower, variety and brilliancy of color, nothing finer in the way of a quilled Aster can be had than this strain. Mixed colors

Betteridge's Choice Quilled, mixed colors

Cocardeau or Crown, large, white-centred Howers, attractive and beautiful ; mixed colors,

Dwarf Chrysanthemum, immense flowers, free bloomer; mixed colors

Giant Emperor, immense, brilliant flowers, very double ; mixed colors

Imbricated Pompon, exquisitely formed small flowers; mixed colors

Hedgehog, Porcupine, or Needle, a variety with large, massive flowers, the petals of which are long, quilled, and sharply pointed; mixed colors

Dwarf Pyramidal Bouquet, so profuse in bloom the foliage is hidden with flowers mixed colors

Truffaut's French Pæony-fiowered Perfection. This is the most perfect type of the Prony-flowered Asters; the habit of the plant is excellent, the flowers are perfect in quality, form, size, and color, choicest mixed

Blue

Scarlet

White 
ASTER. New Washington, without exception the largest Aster in cultivation, the flowers being frequently 4 to 5 inches in diameter, and of perfect form; mixed colors .

Victoria, of vigorous habit, pyramidal form; flowers very large, beautifully imbricated, and freely produced; mixed colors

White, tinted with rose, a new, delicate colored variety, the young flowers of which are particularly charming, and well adapted for bouquet-making

Pæony-flowered Globe, very early variety, vigorous habit and large flowers, very double; mixed colors

"Perennial (Michaelmas Daisies), thrives in any good garden soii; saved from a superior strain ; finest mixed, all colors

AVENA. See Ornamental Grasses,

BABY'S BREATH. See Gypsophila Paniculata.

BACHELOR'S BUTTON. See Centaurea Cyanus.

BALLOON VINE. See Climbers,

BALSAM. See Impatiens Balsamina.

BAPTISIA. (False Indigo.) Of easy culture, producing long spikes of blue, pea-shaped flowers.

Australis, bright blue

BARTONIA. Effective for beds and borders, with yellow flowers and thistle-like foliage. Aurea, large golden-yellow; brilliant in the sunshine

BEE LARKSPUR. See Delphinium Elatum.

BEGONIA. See Seeds for Greenhouse,

BELL FLOWER. See Seeds for Greenhouse,

BELLIS. (Double Daisy.) A favorite plant for beds or pot culture; the seed we offer is saved from the finest double varieties.

" Perennis Alba, fl. pl., pure white double daisy

" " Longfellow, double, rose

" " Rubra, fl. pl., double, red

BIGNONIA. See Climbers,

fl. pl., finest mixed

BLANKET FLOWER. See Gaillardia.

BOCCONIA. Ornamental foliage plants, exceedingly effective as single specimens for lawns or in borders.

Japonica, produces racemes of bloom from 2 to 3 feet long . . . . . BOSTON IVY. See Climbers,

BRACHYCOME. (Swan River Daisy.) A beautiful free-flowering, dwarf-growing plant, covered all summer with a profusion of Cineraria-like flowers; valuable for edgings, small beds or pot culture.

Iberidifolia, blue

Alba, white

BRIZA. See Omamental Grasses,

BRIZOPYRUM. See Ornamental Grasses,

BROMUS. See Ornamental Grasses,

BROWALLIA. One of the finest blue flowers, suitable for pot or garden culture, and very valuable for bouquets.

\section{" Elata, blue}

Alba, pure white flowers :

BYRONOPSIS. See Climbers,

CACALIA. (Tassel Flower.) A beautiful and profuse-flowering genus of plants, of easy culture; continues in bloom all summer.

Cocinea, orange-scarlet, flowering in clusters

Aurea, golden-yellow

CALA NDRINIA. Free-flowering plants, invaluable for edging, rock-work, and dry, hot banks, or similar situations; producing an abundance of blossoms.

Grandiflora, rose, large-flowered

Speciosa Alba, white, fine

CALCEOLARIA. See Seeds for Greenhouse,

CALENDULA. (Marigold.) Showy, free-flowering plants, growing in all situations.

Le Proust, buff, extra

Meteor, perfect double, striped, the petals having a creamy centre edged with orange-yellow

Prince of Orange, large, double, dark orange flowers; a profuse and constant bloomer

CALLIRHOE. Commences to bloom when about six inches high, and presents a mass of flowers during the entire summer

Pedata Nana, violet-crimson

CAMPANULA. (Canterbury Bells.) Neat, showy, and excellent for masses or borders.

Speculum (Venus' Looking-glass), mixed colors

Media, double, mixed

" single, mixed.

Macrostyla, rose

Calycanthema, Mixed

Carpatica, Mixed, blue and white

CANDYTUFT. See Tberis.

$\left|\begin{array}{c}\text { HARD. } \\ \text { AND } \\ \text { DUR. }\end{array}\right|$ F'G'T. $\mid \begin{gathered}\text { PRI } \\ \text { PE }\end{gathered}$

\section{-} PRICE PRICB

h

2

25

\author{
hhA \\ “ \\ h
}

" 


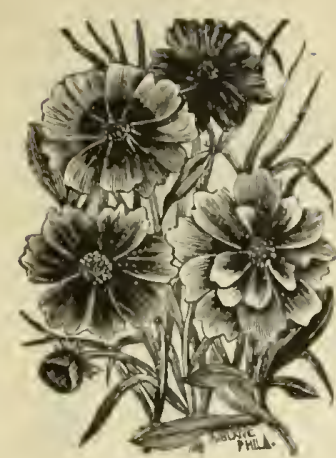

CALLIOPSIS.

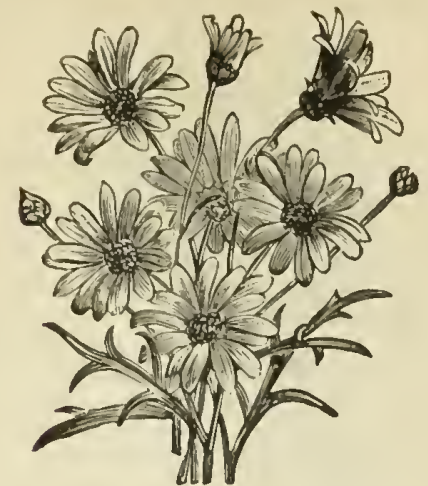

CHRYSANTHEMUM. , Paris Daisy.)

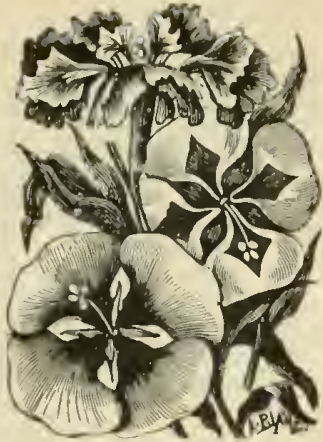

CLARKIA.

NAME.

DESCRIPTION.

\begin{tabular}{|c|c|c|c|}
\hline HARD. & H'G'T & PRICE & PRICE \\
AND & FER & PER \\
DUR. & FT. & PZ. & PKT \\
\hline
\end{tabular}

CANNA. (Indian Shot.) Highly ornamental plants, remarkable for large and handsome foliage, majestic habit, and brilliant flowers: take up the roots before frost and put in a warm cellar.

Anneii, rich crimson

Bonnetti, red and vellow

Crozy's Choice Mixed, brilliant, Gladioli-like flowers

Depute Hernon, leaves deep green flowers sulphur and orange

Indica, red, from India

Nigricans, coppery-red leaves, flower crimson

Zebrina, fine scarlet, striped foliage

Finest Mixed, all colors

CARDIOSPERMUM. See Climbers,

CATCH-FLY. See Silene Armeria.

CASTOR OIL PLANT. See Ricimus.

CARNATION. See Dianthus Caryophyllus.

CELOSIA. (Cockscomb.) Magnificent, free-flowering, graceful-growing plants, producing spikes of feathery flowers; our seeds saved from an extra strain.

Japonica, colors brightest imaginable; cut and ruffed like lace

Cristata nana, choice mixture of the newest dwarf crested varieties, embracing the most brilliant colors

Pyramidalis, choicest mixed, of the plumed or feathered sort

“ Pyramidalis, Plumosa, an improved strain with crimson plumes

CENTAUREA. (Dusty Miller.) Very showy plants; many of the varieties have beautiful silvery foliage, and are indispensable for ribbon-bordering or carpetbedding.

Americana, lilac-purple, showy

Cyanus (Bachelor's Button or Corn Flower), mixed

Emperor William, large, dark blue flowers

Moschata (Sweet Sultan), mixed colors

Suaveoleus, yellow, fragrant

Gymnocarpa, silvery-gray foliage, drooping habit

Candidissima, silvery-white, deeply cut foliage

Clementeii, deeply cut, snowy-white folıage; beautiful

CENTRANTHUS. Very pretty free-flowering, compact-growing plants, producing in clusters, long, tube-shaped flowers.

Mixed, all colors

CERASTIUM. Very valuable for edgings and rock-work.

Biebersteinii, leaves silvery-white

CERATOCHLOA. See Ornamental Grasses,

CHAM EPEUCE. Thistle-like plants, with ornamental foliage; fine for borders.

Cassabonæ (Fish-bone Thistle), dark green foliage, covered with curious hairy spines

Diacantha, variegated foliage, with yellow flowers

CHEIRANTHUS. (Wall Flower.) Well-known fragrant garden plants, with large spikes of beaut iful-flowers.

Double German, finest mixed

Single, fine mixed, all colors

CHELONE. Beautiful plants, with showy Pentstemon-like fowers, very effective in centres of beds or groups in mixed borders.

Barbata, scarlet

Hybrida, mixed, all colors

CHINESE PINK. See Dianthus Chinensis.

CHLORIS. See Ornamental Grasses,

CHLOROPSIS. See Ormamental Grasses,

CHRYSURUS. See Ornamental Grasses, 
DESCRIPTION.

CHRYSANTHEMUM. The annual varieties are among the most showy, effective and desirable of our summer-flowering border-plants; free-blooming and continue in flower till late in the fall.

Tricolor, white, with yellow band; very showy

Burridgeanum, white, with crimson band; fine

Dunnetti Album, fl. pl., double white

A ureum, fi. pl., large double yellow flower

Carinatum Eclipse, pure golden yellow, with a purplish-scarlet ring or centre on the ray florets, the disk being dark brown

W. E. Gladstone, rich crimson; brilliant

Lord Beaconsfield, crimson-maroon, edged and striped with a golden rim surrounding a rich brown eye

The Sultan, rich, velvety dark maroon with a golden rim

Coronarium, double white " double yellow

Sulphureum, fl. pl., double, delicate sulphur-colored flowers

Perennial sorts. See Seeds for Greenhouse,

Frutescens (Marguerite, or Paris Daisy), white, star-1ike flowers, with a yellow centre

Inodorum, double white, free flowering; fine for pot culture

CINERARIA. Fine for ribbon-beds and edgings: silvery foliage.

Maritima, graceful white foliage

Hybrida. See Seeds for Greenhouse,

CIGAR PLAN T. See Seeds for Greenhouse,

CLARKIA. An old garden favorite, with cheerful-looking flowers, beautiful for massing.

Elegans Alba, single white.

Purple King, purple, fine, double

“ Salmon Queen, double, beautiful pink

"Mixed, all colors, single and double.

Pulchella, mixed, all colors .

CLEMATIS. See Climbers.

CLIANTHUS. See Seeds for Greenhouse,

CLINTONIA. Charming little Lobelia-like plants, producing a fine effect as edgings or on rockwork.

Elegans, blue .

¿OB EA. See Climbers,

OCKSCOMB. See Celosia.

OIX. See Ornamental Grasses,

COLEUS. See Seeds for Greenhouse,

COLLINSIA. Free-flowering, remarkably attractive in beds, mixed borders, or ribbons.

Fine Mixed, all colors

COLUMBINE. See Aquilegia.

COMMELINA. Tuberous-rooted, free-blooming border plants.

Coelestis, mixed, blue and white

:ONVOLVULUS MINOR. (Dwarf Morning Glory), remarkably showy plants, with exceedingly handsome, rich-colored flowers, producing in beds or borders, an unusually brilliant effect.

" 3

Tricolor, yellow eye, encircled with a band of white, margined with crimson-violet .

"Rose Queen," rose-colored flowers, centre pure white, margined with crimsom-violet

Splendens, rich violet, with white centre

Mixed, finest varieties

Mauritanicus, beautiful for baskets and vases, flowers blue

zONVOLVULUS MAJOR. See Climbers,

ZOREOPSIS, or CALLIOPSIS. The colors are rich and striking, flowers numerous and beauti-

“
ful, producing a fine effect in borders.

Cardaminifolia, compact variety, purple flowers . . . hA

Drummondi, large yellow flowers

Verticillata, yellow

Bicolor Mixed, all shades

CORN FLOWER. See Centaurea Cyanzs.

OSMANTHUS. Small spreading plant, with very pretty fringed flowers.

Fimbriata, lilac and white

JOSMIDIUM. Large and showy Coreopsis-like flowers, valuable for grouping.

Burridgeanam, velvety, bright orange.

COSMOS HYBRIDUS. Various colors

COWSLIP. See Primula veris.

CRUCIANELLE. A very pretty little plant, desirable for borders or rock-work

CUCUMIS. See Climbers.

Stylosa, pink

CUCURBITA. See Climbers,

CUPHEA. See Seed's for Greenhouse,

CYCLAMEN. See Seeds for Greenhouse, 


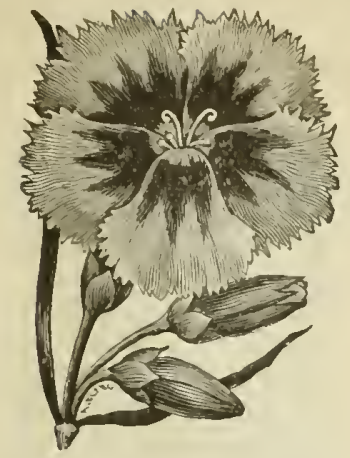

DIANTHUS HEDDEWIGII.

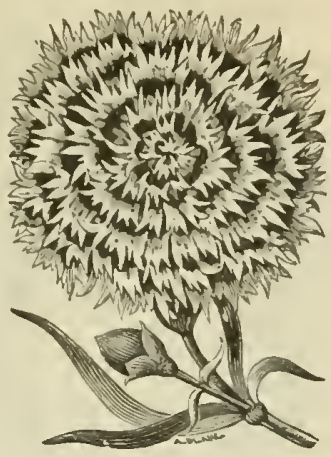

DIANTHUS LACINIATUS, i. pl.

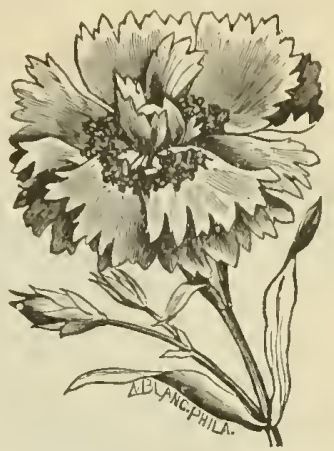

DIANTHUS CHINENSIS

NAME.

DESCRIPTION.

CYCLANTHERA. See Climbers,

SYPRESS VINE. See Climbers,

DAHLIA. One of the best autumn-flowering plants; blooms until killed by frost; our seed is saved from an extra fine collection.

Double, large-flowering, fine mixed

Dwarf, finest mixed

Single, mixed, saved from a superb collection (see Novelties) : $\quad: \quad: \quad: \quad$. hhPt 5

DAISY. Double. See Bellis.

Swan River. See Brachycome.

Paris. See Chrysanthemum Frutescens.

Michaelmas. See Aster Perennis.

DATURA. (Trumpet Flower.) In large clumps, or borders of shrubbery they produce an excellent effect ; the roots may be preserved same as Dahlias.

Fastuosa Huberiana, mixed from a collection of fine double flowers, all colors . hhP $\downarrow$,

Wrightii, white-bordered lilac . . - . . . "

JELPHINIUM. (Larkspur.) Very showy, bearing large spikes of flowers; of great duration.

Hybridum Sulphureum Zalil, fine yellow flowers

Bismark, a beautiful red-striped variety

Candelabrum, double; mixed, all colors

Double Dwarf Rocket, fine nixed

Tall Rocket, fine mixed, all colors

Emperor, profuse bloomer, very double, mixed color

Ranunculus Flowered, very double, extra fine

Tall Branching, fine mixed, double, stock-flowered

Elatum (Bee Larkspur), blue

Formosum, rich dark blue, white centre

Nudicaule, varving in color from light scarlet to a crimson; very brilliant

Hybridum, f. pl., mixed, all colors

DEVIL-IN-A-BUSH. See Nigella.

DEW PLANT. See Mesembryanthemum Tricolor.

DIANTHUS. (Pink) Magnificent genus which embraces some of the most popular flowers in cultivation.

Chinensis, fl. pl. (China or Indian Pink), double mixed

Heddewigii, color varies from the richest, velvety crimson to a delicate rose

fl. pl., double variety of the preceding; very showy

Diadematus, f. pl., dwarf, compact habit of various tints of rose, maroon and purple

Laciniatus, fringed, finest colors, mixed

Crimson Belle, rich crimsoll, good size and substance; beautifully laced

Eastern Queen, beautifully marbled; attractive

fl. pl., splendid; double; variety of colors

Imperalis, fi. pl., all colors mixed

Dwarf, varieties mixed

Caryophyllus (Carnation) f. pl., finest double, mixed

Fine German, from named flowers

Good mixed, for border culture

Early Flowering Vienna, extra fine, mixed

Perpetual or Tree, saved from choicest double mixed flowers

Picotee, finest mixed; all colors

Plumarius, fine mixed; various colors

fl. pl., double, mixed; all colors

Scoticus (1'aisley Pink), ground white, beautifully blotched and edged with shades of purple

Barbatus (Sweet lVilliam), single, nixed

Auricula-eyed, mixed; all colors

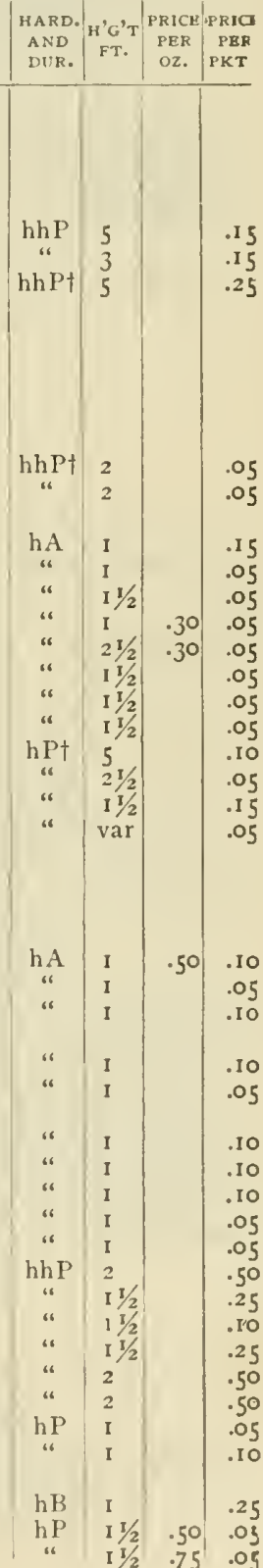

See Special Offers on third page of cover. 
DICTAMNUS. Very ornamental plants; sweet-scented; excellent for bees.

"

DIGITALIS. (Foxglove.) Exceedingly showy plants for shrubberies and other half-shady places.

Gloxiniaflora, mixed; all colors; large-flowered

Grandiflora, yellow, extra

Maculata Superba, beautiful spotted flowers; all colors

Purpurea, purple, spotted

" Alba, white

DIOTIS. Excellent for edgings and borders.

Candidissima, white

DOLICHOS. See Climbers,

DUSTY MILLER. See Centauréa Gymnocarpa.

DUTCHMAN'S PIPE. See Climbers,

ECCREMOCARPUS. See Seeds for Greenhouse,

ECHEVERIA. An elegant succulent, very popular for carpet-bedding.

Mixed, extra ; all shades

ELEUSINE. See Ornamental Grasses,

ELICHRYSUM. SeeEverlastings,

ERAGROSTIS. See Ornamental Grasses,

ERIANTHUS. See Ornamental Grasses,

ERYSIMUM. Showy, free-flowering, very effective in beds; sweet.scented, excellent for cutting. Arkansanum, sulphur-yellow; handsome

ESCHSCHOLTZIA. (California Poppy.) An exceedingly showy, free flowering tribe of plants, attractive for bedding, massing, or ribboning.

Californica, bright yellow, rich orange centre .

Crocea, rich orange

" $\quad$ A. pl., Alba, double white

"Mandarin, the inner side of the petals is of a rich orange color,

Tenufolia (fern-leaved), bright yellow, leaves finely cut

Mixed, all colors

EUCALYPTUS. (Fever and Ague.) Very ornamental; has been extensively planted for the reputation it has of absorbing malaria. Globulus (above is description)

EULALIE. See Ornamental Grasses,

EUPHORBIA. (Snow on the Mountain.) A fine border plant, with foliage veined and margined with white

Variegata, white

EUTOCA. Free blooming, suitable for beds or mixed borders; extra as cut flowers.

Multiflora, pink; a profuse bloomer

Viscida, bright blue

FALSE INDIGO. See Baptisia.

FEATHER GRASS. See Ornamental Grasses,

FENZLIA. A profuse flowering plant, excellent for pot culture or beds; requires considerable moisture.

Dianthifolia, rosy lilac, dark purple throat

Alba, pure white

FESTUCA. See Ornamental Grasses,

FEVER AND AGUE. See Eucalyptus.

FEVERFEW. See Pyrethrum.

FEVERFEW, DOUBLE. See Matricaria.

FLAX. See Limum.

FLOWERING SAGE. See Salvia.

FOUNTAIN PLANT. See.Amaranthus Salicifolius.

FOUR O'CLOCK. See Mirabilis.

FOXGLOVE. See Digitalis.

FUCHSIA. See Seeds for Greenhouse,

GAILLARDIA. (Blanket Flower.) Remarkable for the profusion, size, and beauty of flower: splendid bedding plants.

Picta, red and yellow, handsome
Lorenziana (so-called double), the colors (offered in mixture) are sulphur and golden-yellow, orange, amaranth and claret

GEN TIANA. Fine, showy plants, should be in every collection.

Acaulis, rich blue, vase formed

Cruciata, azure blue

GERANIUM. See Seeds for Greenthouse,

GEUM. Handsome and showy plant, for borders.

Coccineum, fl. pl., double scarlet, fine for cutting .
Rose Cardinal, producing large flowers, of intense carmine the outer side being a brilliant scarlet

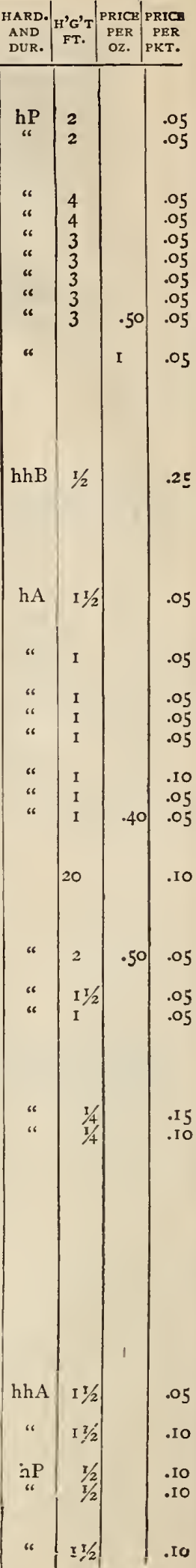

See Special Offers on third page of cover. 


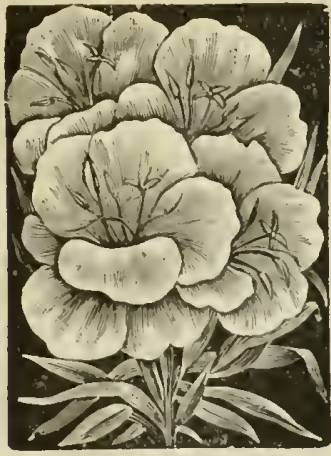

GODETIA.

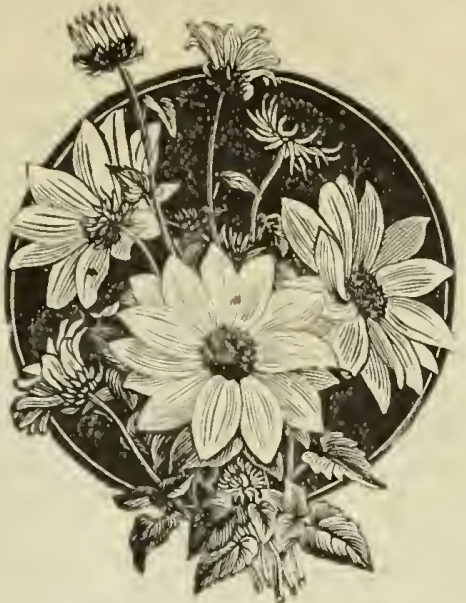

MINIATURE SUNFLOWER.

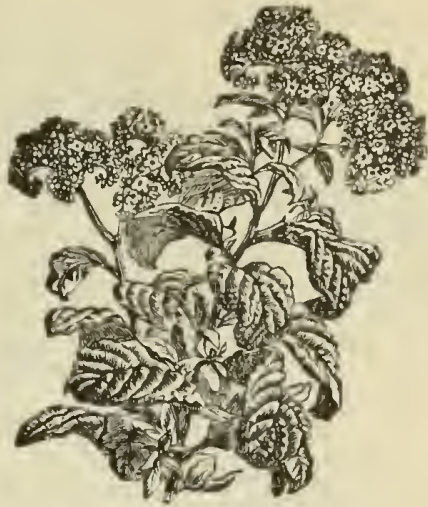

HELIOTROPE.

GILIA. Very pretty dwarf plants, bloom in almost any situation, grow well in pots, and may be placed in a rockery.

"Tricolor, white, lilac, and purple

Mixed, all colors

GLAUCIUM. (Horn Poppies.) Effective for borders, and among the prettiest of our white foliaged plants; their elegantly indented, glaucous green leaves make them Mixed attractive at all seasons.

GLOBE AMARANTH. (Gomphrena.) See Everlastings,

GLOXINIA. Sec Seed's for Greenhouse,

GODETIA. A very desirable, free-flowering genus, attractive in beds, mixed borders, and ribbons. Duchess of Albany, large, handsome, satiny-white flowers

Lady Albemarle, carmine-crimson, compact habit

" The Bride, white, with a rich carmine centre

GOLD DUST. See Alyssum Saxitile.

GOLDEN FEATHER. See Pyrethrum Aureum.

GRAMMANTHES. Beautiful miniature plants for rock-work or rustic baskets, yielding a profusion of star-shaped flowers.

Gentianoides, rich orange scarlet

GYNERIUM. See Ornumentul Grasses,

GYPSOPHILA. A pretty, free-flowering little plant, best adapted for rustic baskets, rock-work, and edgings ; indispensable for bee keepers.

Elegans, white and pink, fine for table bouquets

Muralis, with red flowers, which contrast beautifully with its graceful foliage

Paniculata (Baby's Breath), pure white, fine

HARE'S TAIL. See Ornamental Grasses,

HEARTSEASE. See Viola Tricolor Maxima.

HEDYSARUM. A beautiful border plant.

Coronarium, red.

$$
\text { Alba, pure white }
$$

HELLANTHUS. (Sunflower.) A well-known genus of the most showy plants, remarkable for their stately growth, and the brilliancy and size of flowers.

Giant Russian, single, large flower.

Agrophyllus, yellow, double, leaves silky-white

Californicus, orange, extra large and double.

Globulus Fistulosus, fi. pl., saffron, very double . Multiflora, free-flowering, yellow

Nanus Folius Variegatis, dwarf, with variegated foliage

Oscar Wilde, a small, black-centered variety

Fine Mixed, from above varieties

HELICHRYSUM. See Everlastings,

HELIOTROPE. See Seeds for Greenhouse,

HELIPTERUM. See Everlastings,

HESPERIS. (Sweet Rocket.) Profuse-blooming plants, with deliciously fragrant flowers; unlike Mixed

most plants, they do better if transplanted every second season.

HIBISCUS. (African Rose.) One or the most ornamental, beautiful, and showy plants cultivated, characterized by the size and beautiful color of its flowers.

Africanus, cream color, rich brown centre

See Special Offers on third page of cover. 
HOLLYHOCK. (Althaa Rosea.) This splendid plant, from its stately growth and the varied colors of its magnificent spikes of flowers, may justly demand a place in every garden.

46

Choice Double Mixed, saved from Chater's prize varieties

Fine Double Mixed

HONESTY. See Lunaria.

Fine Single Mixed

HORN POPPIES. See Glacium.

HORDEUM. See Ornamental Grasses,

HUMEA. See Seeds for Greenhouse,

HYACINTH BEAN. See Climbers,

IBERIS. (Candytuft.) Very effective in peds, groups, ribbons, etc., and useful for pot culture for conservatory decoration during winter; indispensable for bouquets.

“ Carter's N ew Carmine, distinct and beautiful, presenting one mass of vivid carmine bloom .

“ Dunnettii, dark rich crimson, splendid strain

Fragrant, pure white

Hybrid Dwarf, very floriferous, choice colors, mixed

Purple

Rocket, white, large trusses

Fine mixed

Pruiti, very dwarf, pure white

Sempervirens, white

ICE PLANT. See Mesembryanthemum Crystallinum.

IMPATIENS. (Balsam.) Magnificent conservatory or out-door plants, producing beautiful, brilliant-colored flowers in the greatest profusion; should receive frequent waterings of manure water.

" Double White

" Double Red

(The above two varieties are unsurpassed for florists' use.)

"Camellia-fiowered, mixed

Dwarf Double, mixed colors.

Rose-flowered, mixed colors

Double Solferino, very beautifully striped and streaked with lilac and scarlet

Fine mixed

Double Victoria, white, scarlet spotted

Atrosanguinea Plenissima, splendid, deep blood red

New Carnation Striped, white, spotted and striped

IN DIAN SHOT. See Canna.

IN DIAN PINK. See Diantluts Chinensis.

IPOM ÆA. See Climbers,

ISOLEPIS. See Omanental Grasses,

JACOB'S LADDER. See Polemonizm.

JOB'S TEARS. See Ornamental Grasses,

KAULFUSSIA. Pretty, free-flowering plants of compact growth, exceedingly effective in beds or mixed borders.

Amelloides, mixed, blue, crimson, etc.

KENILWORTH IVY. See Linaria.

LAGURUS. See Ornamental Grasses,

LANTANA. See Seed's for Greenhouse,

LARKSPUR. See Delphinium.

LATHYRUS. See Climbers,

LA VEN DULA. (Lavender.) Well-known, sweet-scented flower, fine for mixed borders.

Spica, blue

LA VATERA. Tall, showy plants, with Hollyhock-shaped flowers, very effective when used as a background to other plants.

"Trimestris, red

Alba, pure white

LEPTOSIPHON. Of rare beauty both in flower and foliage, exceedingly attractive in beds or ribbons. The colors are blue, white, lilac, purple, and orange.

Hybridus, all colors, mixed

LIMNANTHUS. Easily grown, free-flowering, slightly fragrant plants, excellent for beds or edgings in damp, shady places; splendid plant for bees.

Mixed colors

LIN ARIA. (Kenilworth Ivy.) Admirably adapted for culture in baskets, pots, or vases, and for rock-work it is unsurpassed.

Cymballaria, lilac

LIN UM. (Flax.) One of the most effective and showy bedding plants we have; habit of growth is slender and delicate, like all the Flax family.

Grandiflorum Rubrum, rich scarlet crimson, with darker centre .

Luteum, straw-color.

LOASA. See Climbers,

LOBELIA. Profuse-blooming plants; the low-growing kinds make the most beautiful edgings. AlI the varieties of $L$. erinus are valuable for hanging baskets, rustic work, or vases.

Erinus, deep blue.

See Special Offers on third page of cover. 


\section{NOVELTIES AND SPECIALTIES}

IN FLOWER SEEDS, BULBS, AND PLANTS FOR 1894.

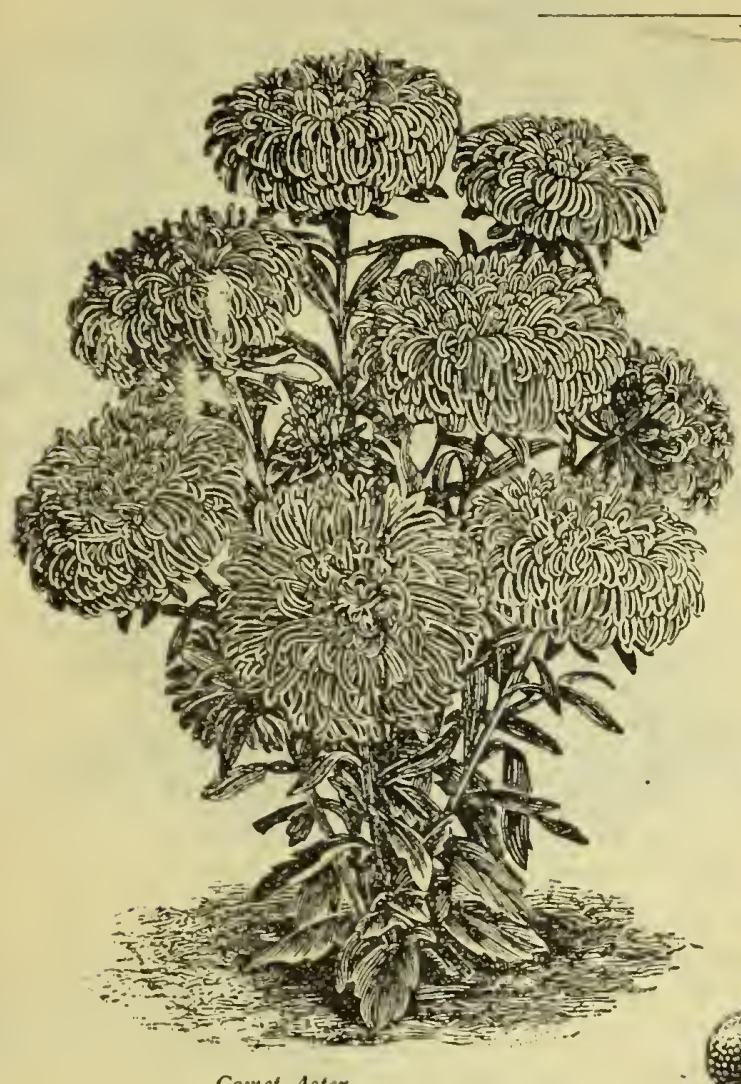

ASTER. Comet, Snow-White and Peaçh-Blossom. The Comet Asters already introduced have been favorably received, as they deserved to be, therefore we have pleasure in bringing under the notice of lovers of this class of Aster two new colors. The Snow-white will undoubtedly become the leader of this section, as it is a superior selection and in all respects ahead of the White Comet or White Plume offered two years ago. The Peach-blossom is also a desirable shade. Both colors come true from seed, and the fowers are perfectly double. Each color, I 5 kents per pkt.

ASTER. Triumph, Deep Scarlet and White. A new and handsome variety of the prony-flowered race. The flowers are regularly striped and produced in oreat abundancé. Pkt., io cents.

ASTER. Boston Florists', White. We can thoroughly recommend this variety to all who wish a first-class Aster either for bedding or cutting. It is grown extensively by the florists of Boston, with whom it is a great favorite on account of its color, sjze, and earliness. Pkt., ro cents; oz., \$5.0o.

ASTER Harlequin. A variety with very oddly spotted and striped double fowers of various colors. They are dwarf in habit and yerv novel. Pkt., Io cents.

ASTER MIGNON. The Mignon Aster is now a well-established popular favorite, and in habit resembles the Victoria section. The plants are semi-dwarf and bear when full-grown 40 to 50 flowers, which have deeply imbricated forets, are of a beautiful shape, and unsurpassed for cutting purposes. For pot culture, also, the plant is a treasure, bearing as it does its lovely flowers with an indescribable grace, and having none of that stiffness characteristic of some other classes of Aster. Until this season it has been offered in three colors only, - white, rose, crimson. We have now five additional shades that will surely be appreciated by all lovers of the Aster. The two first-named varieties in particular are of incomparable delicacy and beauty. Flowers of three distinct shades of color are borne at the same time by one plant, the flowers on forst appearing being pure white, those half-developed changing to white or rose, and finally the full-blown flowers are of a beantiful pure lilac or rose tint. The other three offered are also extremely attractive. White changing to lilac, white changing to rose, peach blossom, rosy-lilac, lilac-red, all colors mixed. Pkt., 25 cents.
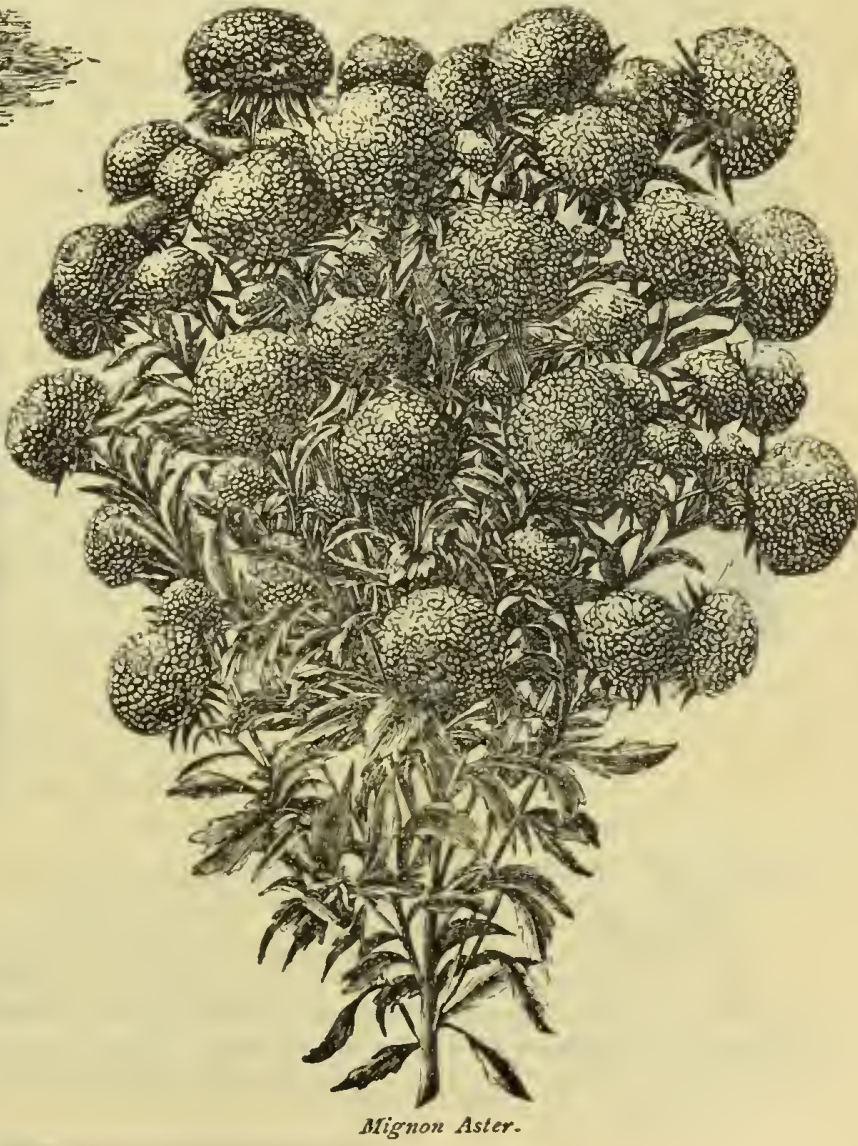
ASTER. Dwarf Victoria the most beautiful of the dwarf class; flowers large and freely produced.

Bright Crimson, packet, $I_{5}$ cents. Pure White, packet, ${ }_{5} 5$ cout's. Dark Scarlet, packet, ${ }^{5}$ cents. All Colors Mixed, packet, 15 cents:

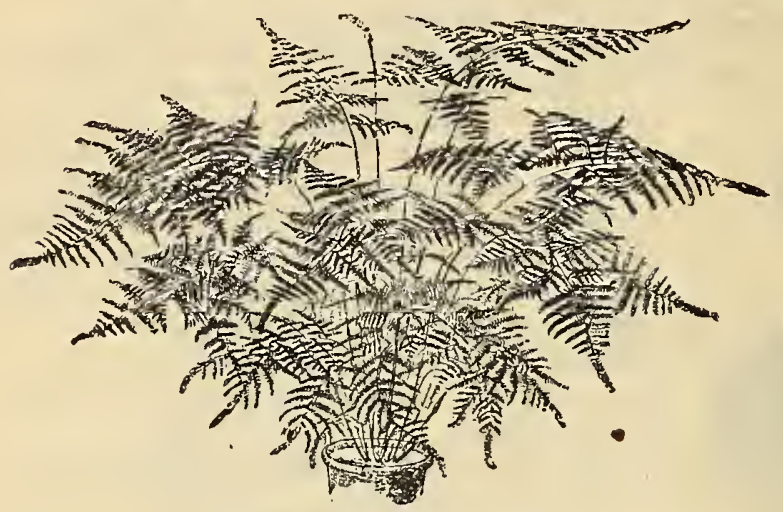

Asparagus Plumosus Nanus.

ASTER JEWEL or BALL. Three very handsome colors of a new and magnificent class of Asters, with perfectly round flowers, which may be compared to the finest varieties of the incurved class of Chrysanthemums. The plants attain a height of about 20 to 24 inches ; the fully developed flowers measuring $21 / 2$ to 3 inches across, they will prove very useful for cutting and bunching. Apple-blossom, deeprose, purple-violet, each color ${ }_{5} \mathrm{cts}$. per pkt.; the three colors mixed, per packet, ${ }_{5}$ cents.

ASTER. Snowball. This is the first of an entirely new class which, from the build of its flowers, is as beautiful as it is distinct. A single plant develops as many as thirty pure white flowers, which, by reason of their refined and faultless form, may be utilized with the greatest advantage, as they remain a longer time in good condition than any other Aster. The Snowball will be found an excellent variety for pot culture. Pkt., I 5 cents.

ASTER. Breck's “International Prize." Mixed. A choice mixture prepared by ourselves from the finest strains
of the best French, German, and American growers. This collection embraces all the choicest varieties, and is especially suited for those of our customers who grow in limited quantity and wish a selection of the many kinds and colors. Packet, 15 cents.

ANTIRRHINUM. QQueen of the North. The plants of this fine novelty grow to a uniform height of one foot, of elegant habit, and densely covered with large white flowers. It is without exception the finest and most beautiful snap-dragon ever seen. Each plant has a spread of from twelve to eighteen inches; it is a gem for the herbaceous border and most useful for cutting. Packet, 25 cents.

ASPARAGUS PLUMOSUS NANUS. We offer new English saved seed of this most beautiful introduction, which is one of the best plants ever sent out, both for its elegant foliage and also for its durability. For bouquets the cut sprays have the advantage of much greater persistency than any fern, retaining their freshness in water from three to four weeks. Packet, 50 cents.

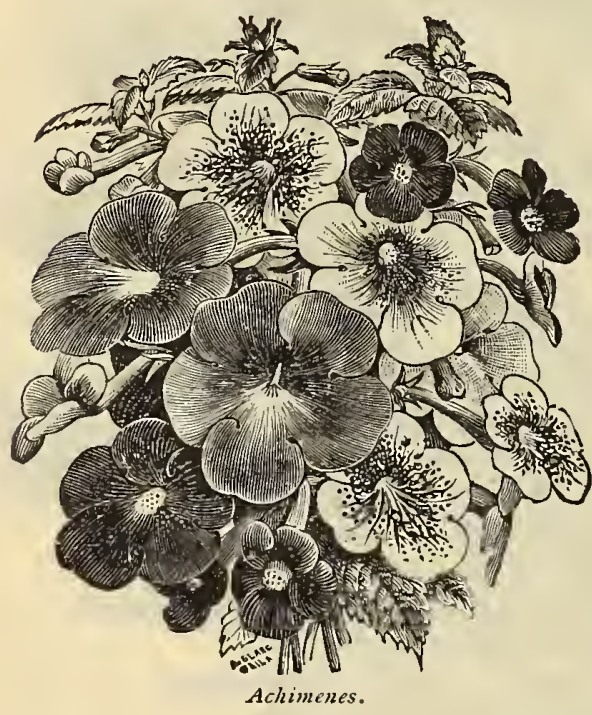

ACHIMENES. Fine Mixed. Favorite plants for greenhouse and conservatory; for delicacy and variety of color, this strain is unsurpassed, ranging from pure white to deep scarlet and purple through the various shades of rose-pink, orange, and blue. Packet, 15 cents.

AGERATUM NANUM LUTEUM. This favorite annual, so largely used for bedding, was hitherto represented only by two colors, blue and white. There is no doubt that the addition of a new color of so popular a flower will be greatly appreciated, all the more as the new color, a inost delicate and beautiful criämois, harmonizes well with those other hues which are the favorites of the

day. It comes perfectly true from seed. Packets, 5 cents.

AGERATUM. Tom Thumb. Large Flowering Rose. This beautiful variety forms bushy compact plants about I2 inches high, bearing large trusses of rose-colored flowers in such abundance as to almost cover the plant. Like all Ageratums, this blooms continuously, and for beds, in the flower-garden, either for edgings, ribbon planting, or for masses, it is very effective until frost, and is equally as desirable for pot culture or as a basket or vase plant. Price per packet, Io cents.

ANEMONE. Japonica Alba (Honorine Jobert). One of the most beautiful autumn-flowering, hardy perennials, witl pure white flowers; excellent for grouping, and very fine as single specimens in the border. Seed should be started in March in light, rich soil, and transplanted as soon as the ground is open. Packet, Io cents. 


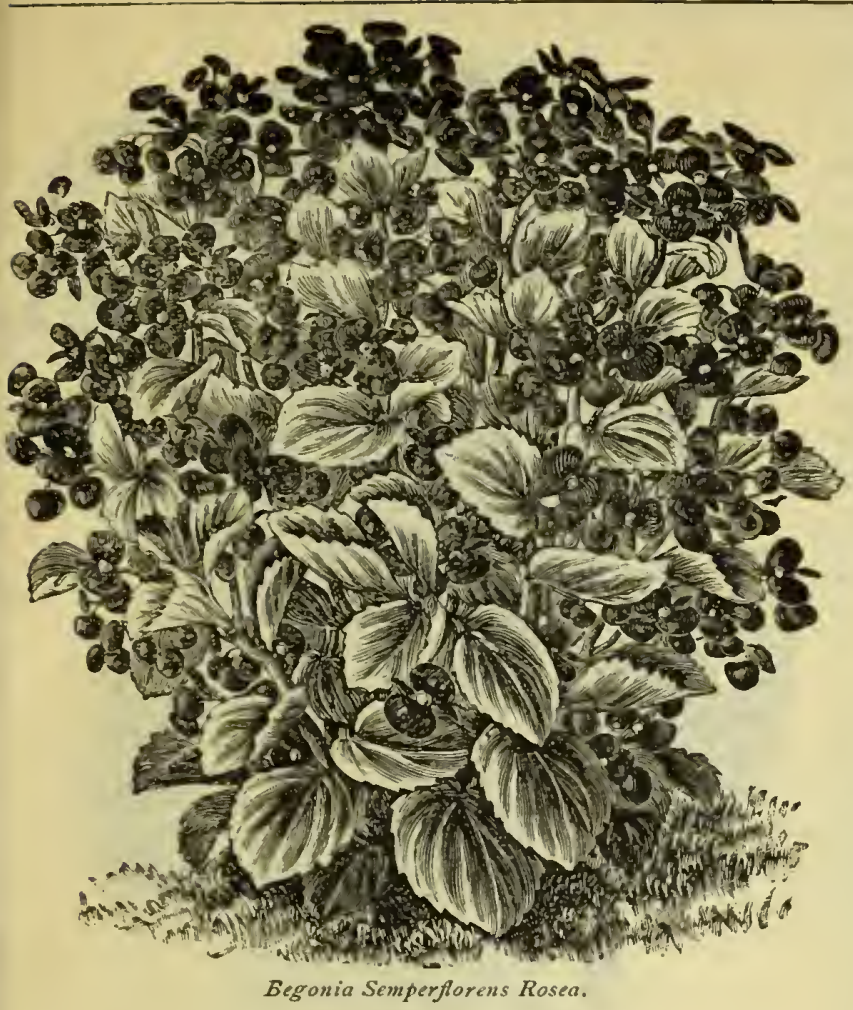

ARNEBIA CORNUTA. The curious andexceedingly beautiful flowers of this plant are about the size of a quarter dollar, of an agreeable, rich yellow, and marked with five large black spots; the latter turn the second day to deep maroon, the third day this color vanisines and becomes clear, pure yellow. From a hundred to a hundred and fifty spikes of flowers may often be seen on one plant. Seeds should be sown in March in heat, and the plants set out in May. Packet, 25 cents.

BEGONIA ELFORDIA. A new cross between B. Schmidli and B. Semperflorens Ver. non. Its growth and graceful habit are similar to the former species, while the coloring of the leaves resembles the lat ter. The flowers, of a lovely rosy car. mine, appear most profusely in loose clusters, and are in beautiful contrast to the dark foliage. It is a splendid bedder,

fand also a good winter-blooming variety. Packet, 25 cents.

BEGONIA SEMPERFLORENS ROSEA.

The true ever-blooming species. Blooms to perfection every day in the year. If you like Begonias, and desire the best one for fine cut flowers, or the best bed-

ding, basket, pot, or market variety, you will secure plants of Begonia semperflorens rosea. It is the quickest growing and most abundant blooming of them all. The plants we ofier are true to name. Each, 35 cents.

BEGONIA VERNON. This new Begonia seems to have been accepted as the most useful novelty in Begonias that has been introduced for some time. In habit and freedom of bloom it resembles the well-known $B$. semperforens rosea, but the flowers are a rich orange carmine, and the foliage, a glossy red. The stamens are yellow, which gives an especially brilliant effect to the staminate flowers. Spring-sown seed will produce blooming plants early in the summer; the flowers will continue to be borne in profusion until

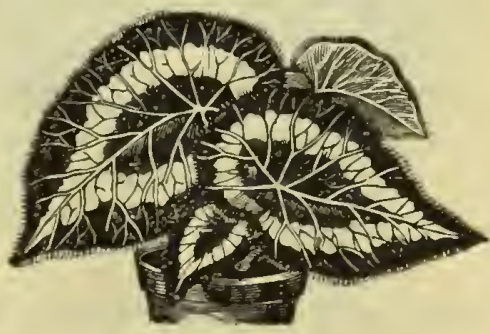

Rex Begonia. killed by frost. Valuable alike for bedding and pot culture. Packet, 25 cents.

BEGONIA. Tuberous-Rooted, New Striped. The raiser of this new class of Begonia describes them as containing nearly all the colors of the older varieties, the flowers being distinctly striped or marked like a carnation, with a great variety of pleasing shades of white, yellow, and red. An interesting and valuable novelty. Packet, 25 cents.

BEGONIA. Single, Tuberous-Rooted "International Prize." This strain is of unsurpassed quality, being the result of cross-fertilization of only those hybrids of recent introduction which for sturdiness, brilliancy of color, together with forın and size, have proved far superior to those of older date. Packet, 25 cents and 50 cents.

BEGONIA. Improved Mont Blanc, a great improvement on this well-known, white-flowered variety, both in habit and size of flowers. Packet, 25 cents.

BEGONIA. Rex, ornamental-leaved varieties, a splendid mixture saved from an extensive German collection. Packet, 25 cents.

BELLIS PERENNIS. Snowball, a beautiful white-flowered variety of the double daisy, producing at least So per cent. of double flowers. Packet, 15 cents.

BELLIS PERENNIS. MAXIMA FL. PL. Giant Double Daisy. An extremely fine strain of double daisies. The flowers are very large, nearly two inches in diameter, perfectly double, and borne on long stout stems. The colors vary from deep crimson to light pink. We belleve this variety will prove valuable for florists' use. Packet, 25 cents. 
CENTROSEMA GRANDIFLORA. " Lookat-Me." An exceedingly ornamental hardy perennial climber, new to cultivation, and of such great merit that it is sure to immediately gain favor with all who love and grow flowers. The flowers are inversely pea-shaped, and are quite large, many of them being two and a half inches in diameter. In color they run through all the shades from rosy violet to reddish purple. Through the centre of each flower runs a broad, feathered band of white, and the large buds and outside surface of the flowers being also white, at a little distance one plant appears' to bear blossoms of several different colors at one time. A most attractive feature of this plant is the way in which the flowers look you in the face. Every imaginative person sees faces in the pansy, and the Centrosema is even more suggestive. Therefore "Look-atMe" is an appropriate name for it. The blossoms are produced in great abundance, sometimes from six to eight in a cluster. Another pleasing feature of this plant is the fact of the foliage being not only very graceful, but delightfully fragrant. The stems are slender, curving and twining over any support with the utmost grace. They are not much larger than good-sized knitting needles, but they often climb to a height of six to eight feet. We particularly recommend all our patrons to give this novelty a trial, as we are sure all will be delighted and surprised with it both in the garden and as a house plant. Pkt., I 5 cents.

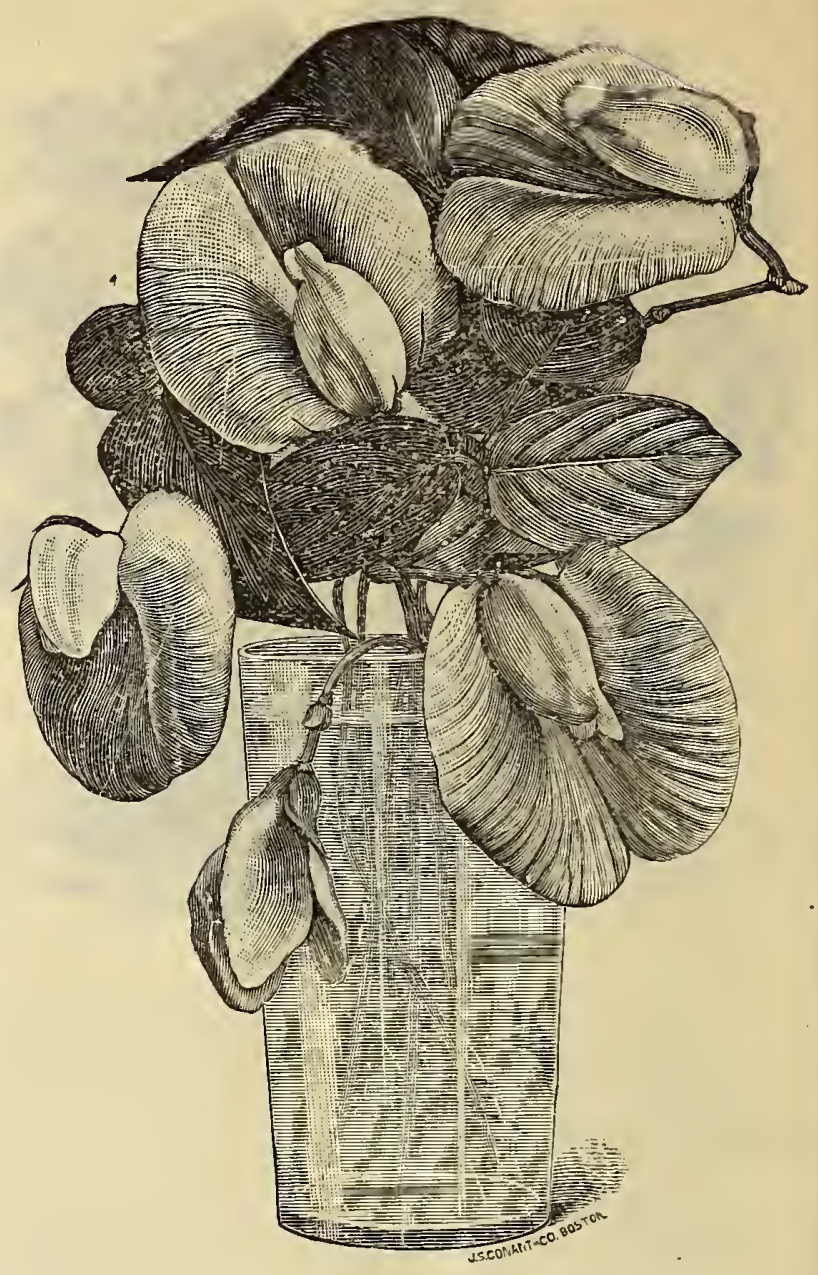

Centrosema Grandiflora.

CALENDULA GRANDIFLORA SULPHUREA. The Calendula is one of the easiest grown and most popular garden flowers, therefore any improvement in its habit, size, or color is sure to be gladly welcomed by many. In C. Grandiflora Sulphurea, we offer a variety that for compactness of habit, size and form of flower, doubleness and bright color, has no equal. The flowers are of immense size and quite double to the centre; the color is a bright sulphur yellow. Pkt., ro cents.

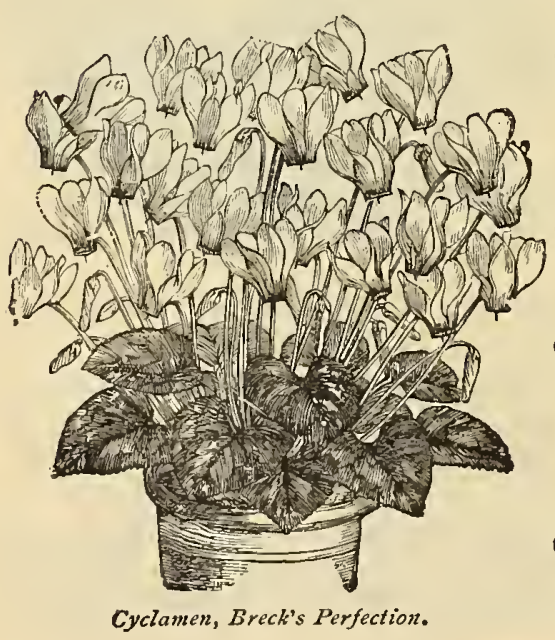

CYCLAMEN PERSICUM GIGANTEUM CRUENTUM. This extremely fine new form of $C$. Giganteum is the deepest and most intense crimson-colored variety in existence. The flowers are as bold and handsome as those of the other Giganteums; they are very effective by artificial light and make a pleasing contrast. Pkt., 50 cents.

CYCLAMEN, Breck's Perfection, Mixed, consists of the finest and most beautiful new sorts; unsurpassed for richness ánd variety of color, and certain to give unqualified satisfaction. Pkt., 50 cents. For a complete list of Cyclamens, see page 82 .

CLEOME PUNGENS. Giant Spider Plant. This is a showy, vigorous-growing native annual, but little known, yet worthy of general cultivation. It attains the height of about four feet, produces long curious spikes of flowers of a bright rose color, with long antennæ-like stamens, giving a very graceful and cloud-like effect. It is of easy cultivation and blooms throughout the entire season. Pkt., 5 cents.

CENTAUREA. Cyanus Minor, Double-Flowered. The flowers in form may be compared to Gaillardia Lorenziana; they form masses of bloom of great beauty, 60 to 70 per cent. double flowers produced from seed. Pkt., Io cents. 


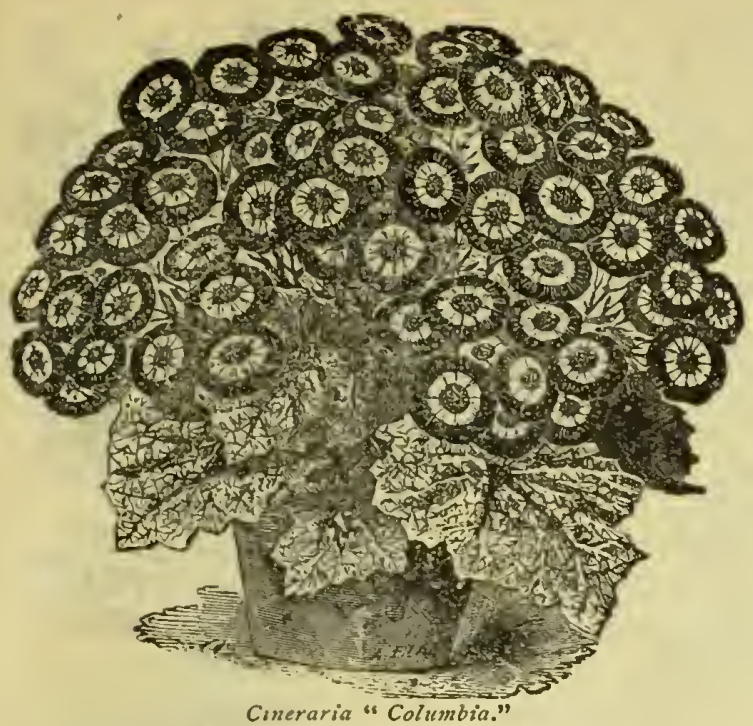

CINERARIA GRANDIFLORA. " Columbia." A new American strain that surpasses any yet introduced from Europe, in size of flowers, variety of colors, and habit of growth. We hope all who grow Cinerarias will try a packet of the Columbia, in order to contrast its relative value with other much-lauded selections. Pkt., 25 cents.

CINERARIA. James and Wetherell's superb strain. The plants are sturdy and compact in growth, and the flowers of the finest shape and substance; they embrace the richest and brightest colored selfs, also the most varied, showy, and attractive varieties, with clearly defined and elegant margins, and rings of various shades. Pkt., 25 cents.

CINERARIA. Covent Garden Strain. Pkt., 25 cents.

CINERARIA. Plenissima, as received from the German growers. Pkt., 50 cents.

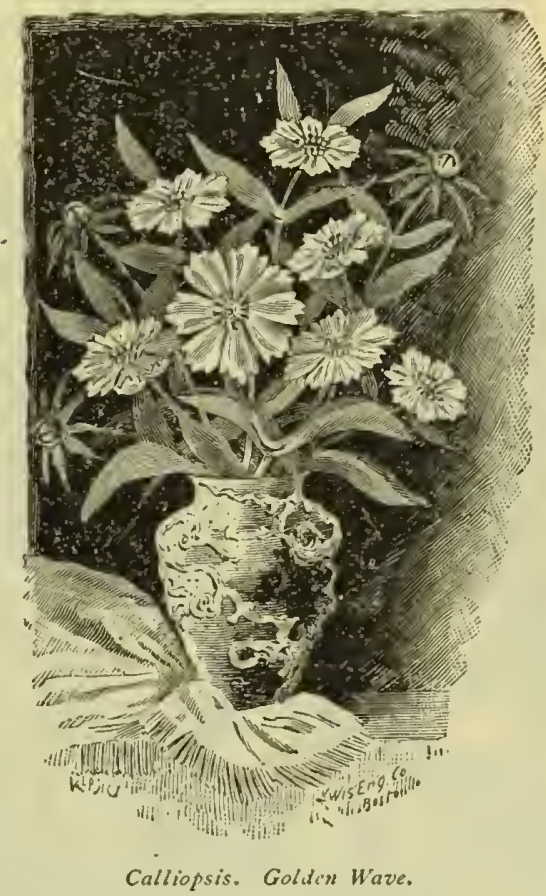

CANDYTUFT. Zirngibel's Giant Spiral, an im. proved form. of Rocket Candytuft, with large spikes of pure white flowers. Pkt., lo cents.

CALCEOLARIA. Thompson's "Dalkeith Park" Strain. The flowers are rich and beautifully spotted and marbled, and of remarkably fine form and substance; habit dwarf and compact. Pkt., 25 and 50 cents.

CELOSIA. Glasgow Prize, Syme's Improved Dwarf, compact variety, with crimson combs which often measure over a foot across; distinct and handsome. Pkt., ro cents.

COBFA, Scandens Alba (White Cobsa), the new, white-flowering variety of this charming, well. known climbing vine. Pkt., 10 cents.

CALLIOPSIS. Golden Wave. For a mass of briglit golden color this is one of the most effective of hardy annuals. I'lants grow about two feet in height, bushy and compact, and are covered from July to October with hundreds of beau. tiful golden blossoms. Pkt., ro cents.

See Special Offers on third page of cover. 
CALIFORNIA GOLDEN BELL. Emmanthe Pendulifera. A decided and meritorious novelty from California. It is an annual, forming bushy plants, nine to twelve inches high, each branch is loaded with broadly bell-shaped pendulous unwithering flowers, about one-half inch long, of creamy-yellow color. The general effect of a branch is very suggestive of a long spike of Lily of the Valley, with large yellow bells, the follage, however, is pinnatified. Pkt., 5 cents.

CHRYSANTHEMUM. Chinese and Japanese. If the seed be sown in heat early in the spring, transplanted several times and properly treated, strong plants may be had full of flowers in the autumn. The seed we offer embraces the choicest varieties in cultivation, including Incurved, Pompone, Japanese, and Chinese varietıes. Pkt., 25 icents.

DAHLIA. Single Cactus. This new type originated with E. J. Lowe, Esq., F.R.H.S., and has already among its admirers many of the leading horticultural authorities of the day.

Their most important characteristic is the twisted or fluted, petals, similar to those of the Double Cactus varieties, and wherever exhibited they have attracted particular attention because of their remarkably grace-

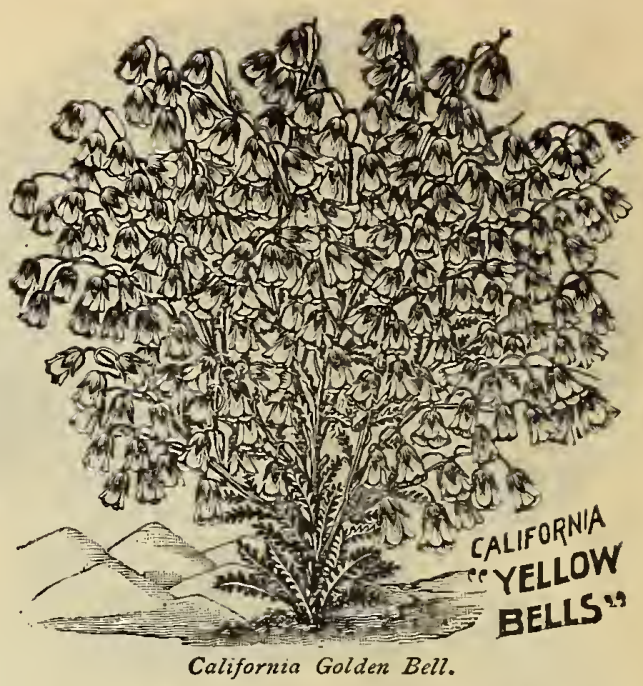

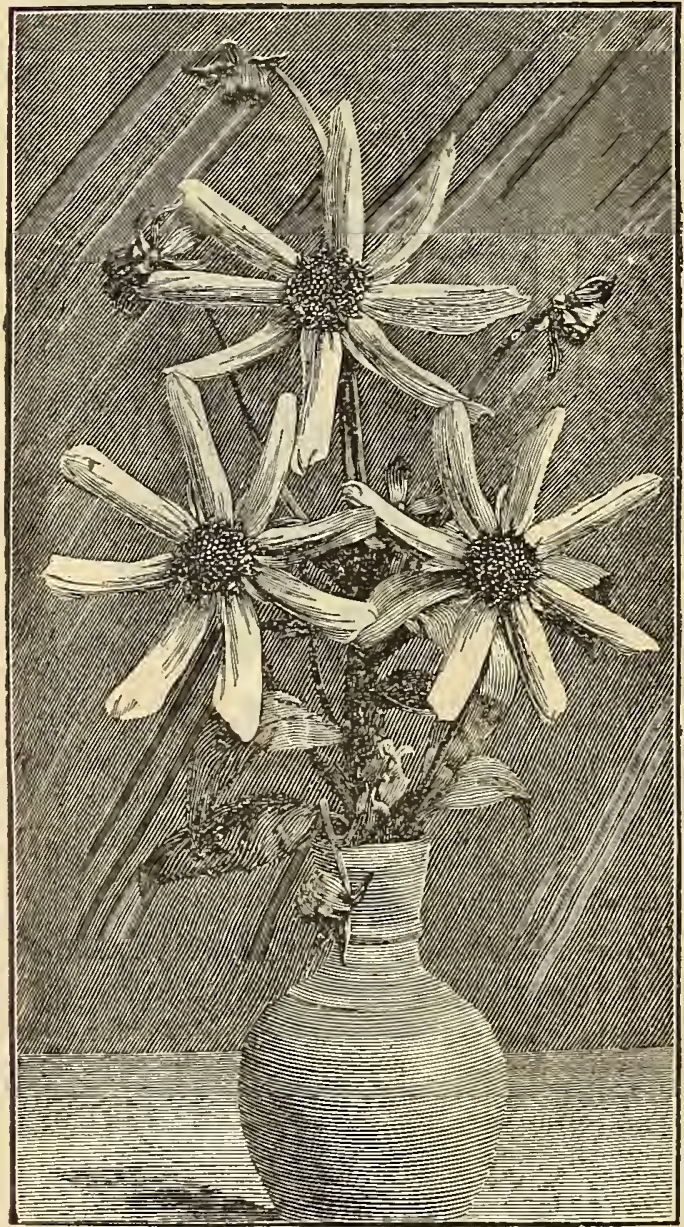

Single Cactus Dahlia.

ful appearance; and they have none of the formality and stiffness so characteristic of the other sections, while the range of color they embrace is quite as rich and varied.

"Single Cactus Dahlias are a new type, having somewhat twisted petals. The colors are beautiful, and for decorative purposes they will be much in demand." - Fournal of Horticulture. Pkt., 50 cents.

DAHLIAS. The Dahlia is an old-fashioned flower, and a great favorite with all amateurs on account of its ? easy cultivation and brilliancy and profusion of flowers. Because of its vigorous growth it has, hitherto, not been considered as adapted for bedding purposes. This trouble is now overcome by the new strain of Dwarf Bedders. These striking novelties are only about twelve inches in height, and they only need to be seen to be appreciated for their extreme value as bedders, or for edgings to beds, borders, or shrubberies. The plants are of a close, compact habit, as will be seen by the illustration, and they produce a dense mass of flowers of the most brilliant colors. Pkt., 25 cents.

DAHLIA. Breck's Premier Single, finest mixed. Pkt., Io cents.

DAHLIA. Paragon, maroon, edged with red. Pkt., 10 cents.

DAHLIA. Sulphur Queen, soft yellow. Pkt., to cents.

DAHLIA. White Queen, pure white. Pkt., Io cents.

DAHLIA. Zimpani, deep, rich crimson, almost black, flowers small and graceful; very distinct. Pkt., Io cents.

DAHLIA. Jaurezii (Cactus Dahlia), dazzling scarlet, long petals, curiously twisted at the points, resembling somew hat the flowers of a Cactus. Pkt., I 5 cents.

DAHLIA. Double Large Flowering, choice strain, saved from the best show and fancy varieties;

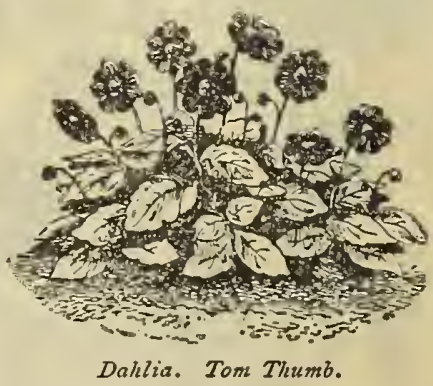
mixed colors. Pkt., Io cents.

DAHLIA. Double Lilliput, small flowering variety of dwarf habit, splendid for bedding; very free flowering. Pkt., 10 cents.

DODECATHEON. Clevelandi. Beautiful perennial; a native of California; produces flower stems fully one foot high, which are surmounted by six to ten large cyclamen-like flowers of violet blue, with yellow and black centres. Pkt., io cents.

See Special Offers on third page of cover. 


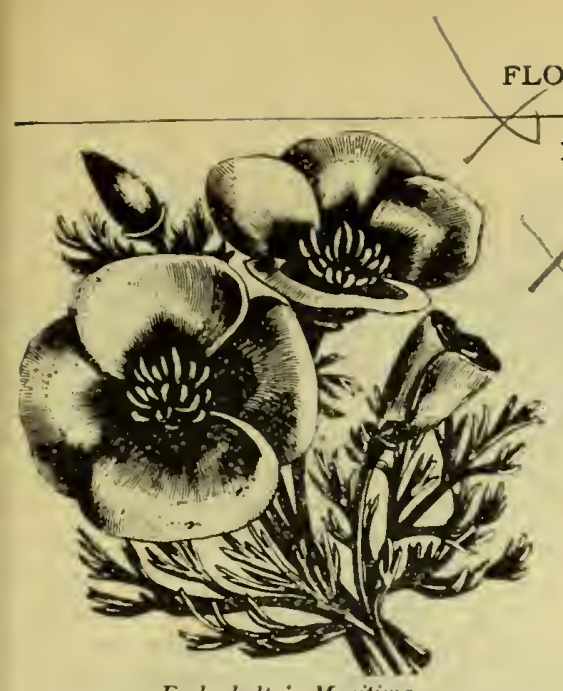

Eschscholtzia Laritima.

ESCHSCHOLTZIA MARITIMA. This new Californian Poppy distinguishes itself essentially from the'well-known $E$. California by its whitish gray foliage and the lighter colored flowers. The latter are of a bright light yellow with deep orange and very distinct spots at thebase of each petal. Pkt., 25 cents.

ESCHSCHOLTZIA. GIANT CALIFORNIAN. This new giant variety is destined to great popularity, for the flowers are enormous, measuring four to five inches across, and are borne in such lavish profusion as to fairly hide the plants, although the latter are unusually robust and luxuriant. Pkt., 10 cents.

GERARDIA TENUIFOLIA. Beautiful half-hardy perennial from Mexico, allied to the tribe of Pentstemon. It forms regularly branched, erect bushes of twelve to fifteen inches in height with narrow, linear foliage. The Howers, one and one-half inches long and one inch in breadth, are of a light violet color with a light lilac throat. If sown early in spring and cultivated like Pentstemon, the seedlings will begin to bloom in July-August; if sown with other perennials

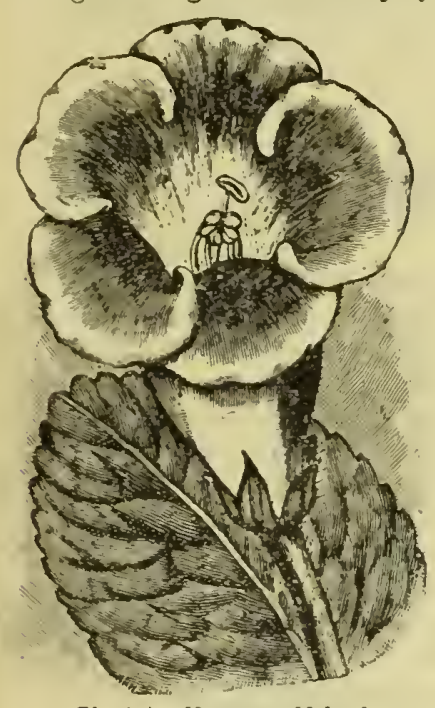

Gloxinia Helhersel Hybrid. in summer and the plants kept througl the winter, the flowers will appear from June incessantly until the autumn. When in full bloom the plants have a close resemblance to some species of Bellflowers. Fine plant for pots as well as for out-door culture. Pkt., $25 \mathrm{cts}$. GLOXINIA. Hetherset Hybrid The flowers measure three to four inches in diameter, and are erect-

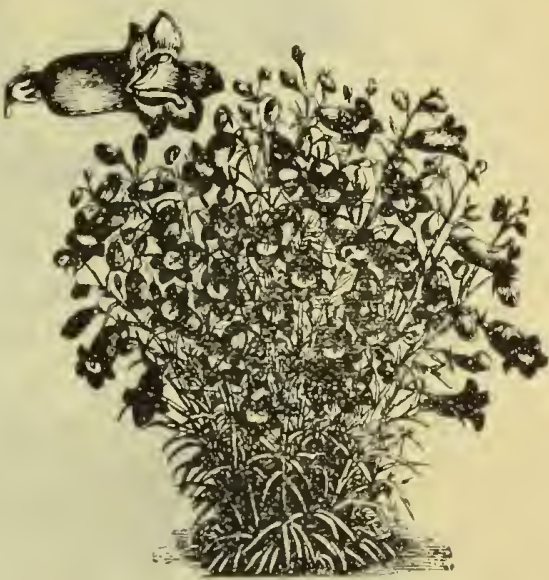

Gerardia Tenuifolia. flowered with large open throats, thus displaying their gorgeous colors to the greatest perfection. The colors are of every conceivable shade of white, pink, clear rose, lilac, scarlet, crimson, maroon, purple, to the richest purplish black, nearly all profusely spotted in the throat, and some having the limb heavily marked with color without spots. This variety was introduced by us a few years ago. We have received many letters from persons who have grown it, setting forth its merits in the most unqualified language. We reconmend it as the best strain on the market. Pkt., 5o cents.

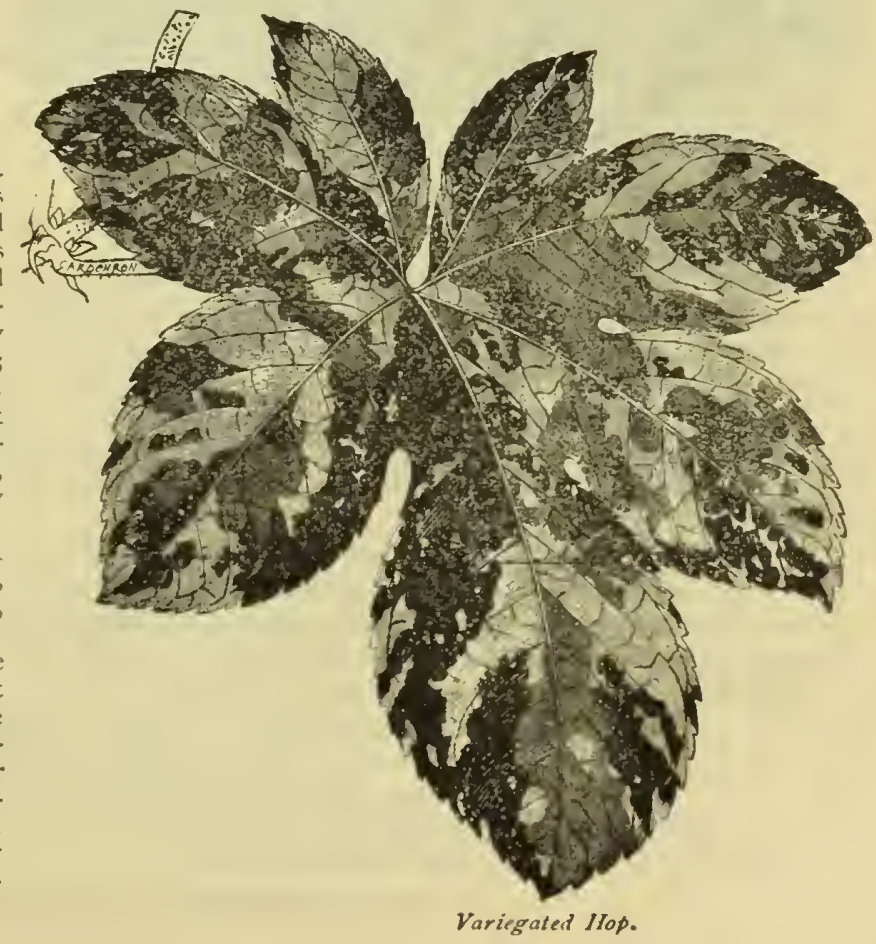

See Special Offers on third page of cover. Hop. The Japanese one of the most useful, fast-growing annual climbing plants in cultivation. In this new variety the leaves are beautifully and distinctly marked with silvery white. yellowish green, and dark green, irregularly striped as well as blotched and marbled; sometimes the leaves are almost white A valuable feature of this Hop is that it is never injured by insects, and never suffers from the heat, but retains its fresh, lively, variegated foliage until killed by frost. Pkt., I 5 cents.

HUMULUS. Japonicus. (Japan Hop.) A rapid-growing, climbing hop from Japan, useful for covering,up stone walls, fences, or trellises. Pkt., Io cents.

HEUCHERA SANGUINEA. One of the handsomest hardy porennials of recent introduction, and well worthy a place in the herbaceous border of both amateur and florist. Its general character is sufficiently indicated in our illustration. The flowers are of a rich crimson color, the leaves light green and slightly hairy. The graceful tlower-spikes furnish a splendid material for bouquets. Pkt., Io cents. 


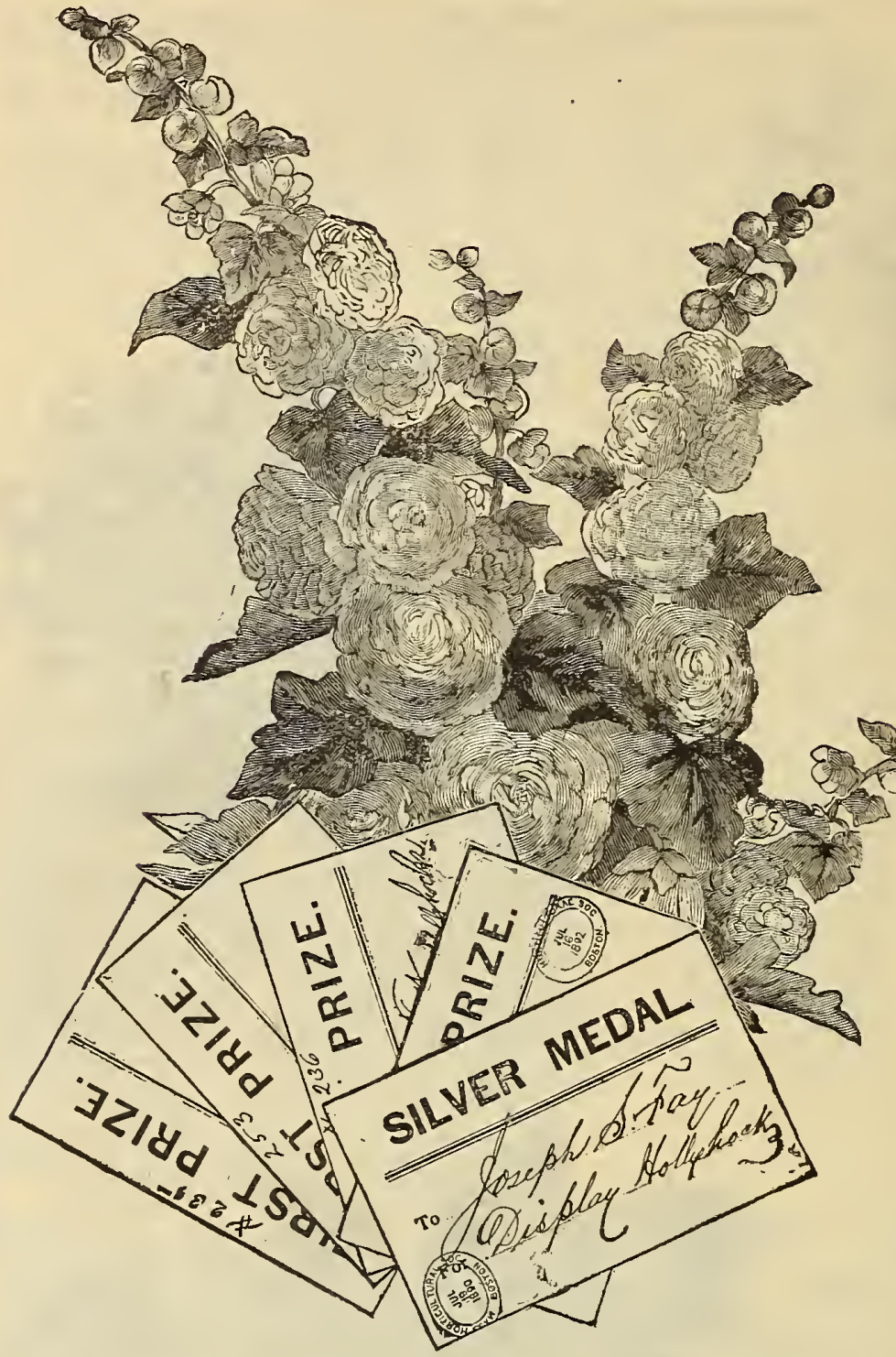

HOLLYHOCKS. Silver Medal Strain. This strain of Hollyhocks is the admiration and wonder of all who have seen it. No other collection, commercial or private, at all approaches this in variety of shades of color, length of spikes, profusion and texture of flowers and foliage. It includes the cream only, much improved, of all collections in existence, and its poorest specimens are superior to the best of all others. Persons who have grown hollyhocks and been disappointed should give the Silier Mcdal Strain a trial, for we are sure it will not only please and surprise them by its immense number of colors, - twenty-five, - and also by its gigantic, healthy plants, beautifully clothed with large, clean foliage, studded with enormous brilliant flowers that shame the rose in variety of form and brightness.

We have been fortunate enough to secure a supply of seed in twenty-five colors from this famous collection, which we have pleasure in offering our custom. crs; and to enable purchasers of it to obtain best results we give particulars of the method of cultivation adopted by the originator of this strain: "Hollyhocks intended to flower the following summer slould be transplanted in October. Seeds sown in May or June will flower in July of the following year. Seeds sown in July or August will flower in August and early in Sertember the year after. Hollyhocks delight in rich, dry soil; the ground should be dug two feet deep and well enriched

with barnyard manure. They should not be planted too close together, $3 \times 3$ feet at least and $3 \times 4$ feet for handsome plants and good specimen fiowers. About the Ist of December the plants should be protected by laying on the crown of the plants a branch or two suflicient to keep the barnyard litter or leaves from pressing too heavily, and causing the crown of the plant to decay; six or eight inches of leaves or litter is sufficient, care being used not to put too much on the crown, putting most around the plant. In spring, about roth or I5th of March, half of the covering should be removed, shaking up lightly ower the plants the other half. During May and June, they may receive abundance of water, as the stalks and foliage absorb a great deal of moisture.

Seed of the following color is obtainable only in packets sealed with our trade-mar-k label.

Pure white, blush white, French white, royal white, white, purple centre, carmine, red maroon, dark maroon, black maroon, salmon, apple blossom, light crimson, dark crimson, light rose, dark rose, salmon rose, ruby, yellow with dark ground, canary yellow, sulphur yellow, Aurea y'ellow, lemon yellow, violet purple, light purple, variegated, white and pink.

Either of the colors, per packet . . I5 cents per ounce - . \$2.50

All colors, mixed, " . . I5 cents per ounce . . $\quad 2.25$

Collection of 25 colors a part, $\$ 3.00$.

PLANTS. - Separate colors, 30 cents each; $\$ 3.00$ per dozen; $\$ 20.00$ per hundred; in mixture, 25 cents each; $\$ 2.50$ per dozen; \$1\$.00 per Ioo. 


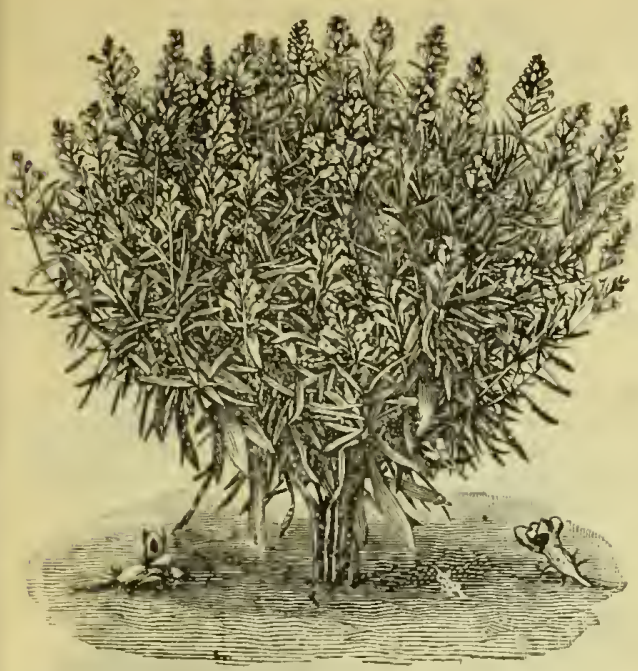

Linaria IJendersoni Ericoides.

LINARIA HENDERSONI ERICOIDES. The plant grows only eight inches high, but branches out laterally to the space of ten inches. The thin flat stalks are thickly covered with smooth, narrow, sage-green leaves, forming a bush from which sprout up the cornshaped spikes of flowers, giving the plant somewhat the appearance of a lleath, on which account I have given it the name of Ericoides. Individually the small snapdragon-like flowers are of a purplish-violet color, striped and veined with lines of a darker shade.

This Linaria is a perenmal plant, but may be treated entirely as an annual, as the seedlings bloom very early the first year. They produce an uninterrupted succession of bloom until late in the allumn. The variety comes nearly true from seed, submits willingly to being transplanted, and will flourish in almost any soil. For dwarf beds and borders, as welt as pot-culture, this novelty will be found very useful.

The sowing must be made under glass early in March, and as soon as the seedlings are strong enough they should be planted out where they are to bloom. Pkt., 25 cents.

LOBELIA ERINUS COMPACTA. Golden Queen. A valuable addition to our list of desirable Lobelias. This variety, in general habit, resembles $L$. Blue King, but has golden-yellow follage, which is a pleas-

ing contrast to the profusion of darkblue flowers. It is sure to become popular for edging, as its bright-yellow leaves make it attractive even be. fore the flowers appear. Pkt., 15 cents.

LOBELIA, BARNARD'S PERPETUAL. This splendid novelty is without doubt the finest Lobelia yet raised. The flowers are of the most brilliant ultramarine blue, strikingly ornamented with a pure-white marking at the base of each of the two lower petals. It is of compact habit, and alike useful for bedding or growing in pots, white the bright and effective coloring of its flowers, combined with its perpetualblooming character, ensures it the premier position in parterres and rib-

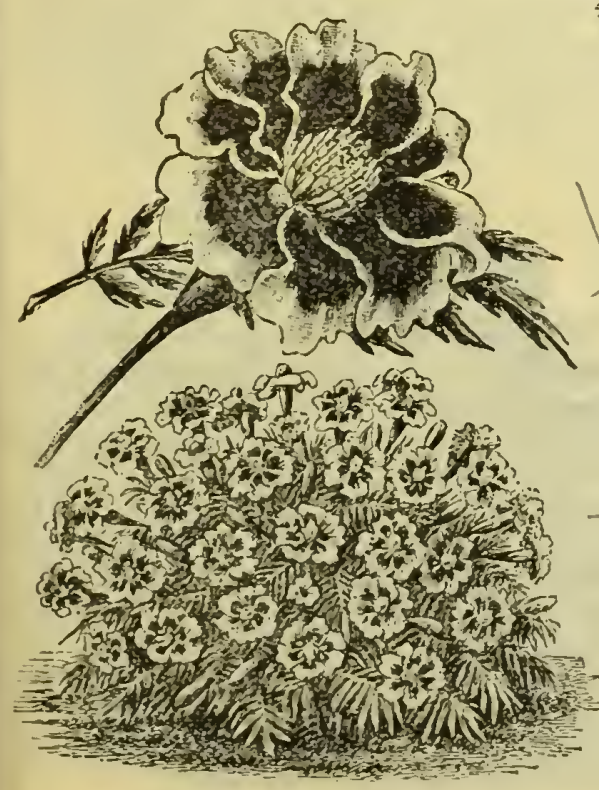

Marigold, Purple and Gold.

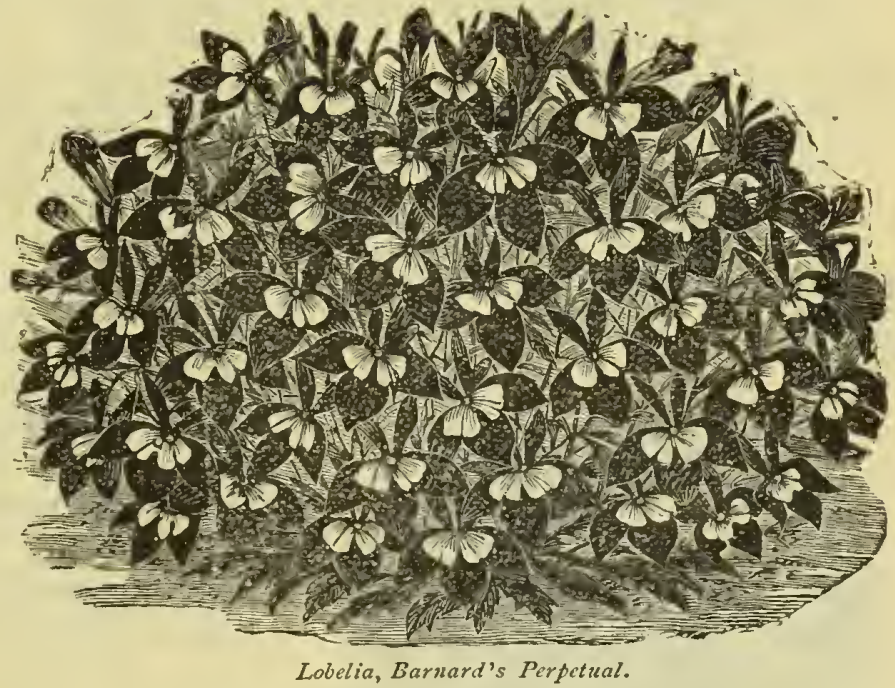

bon borders. It was awarded a certificate of merit by the Royal Horticultural Society, when exhibitẹd in May, IS92, at the Temple show. Pkt., 25 cents.

MARIGOLD, Dwarf French "Purple and Gold." This charming new Marigold grows quite regularly and only abolit twelve inches high, and produces urinterruptedly from July until frost sets in a great profusion of single flowers about $\mathbf{3} 3 / 4$ inches across, of a lovely golden yellow with a purple velvety spot on each of the six or eight petals. The lovely fragrant flower, which much resembles the star of an order, offers an invaluable material for cutting purposes for bouquets, etc. Abundance of flowers, easy culture, and absolute resistance against dryness and insects make this novelty a most valuable plant for any place in the garden. Pkt., 25 cents.

MYOSOTIS ALPESTRIS ROSEA. This is a new and distinct deep rose-colored Forget-me-not, of the large flowering type, that will prove a desirable companion to the popular white and blue sorts already on the market. Pkt., 25 cents.

MYOSOTIS DISSITIFLORA. Forget-me-not. Clear blue, very early, and continues a longr time in bloom; valuable for spring bedding. Pkt., I5 cents.

MYOSOTIS DISSITIFLORA. Alba. Pure white, a counterpart of the preceding, except in color. Pkt., 15 cents.

See Special Offers on third page of cover. 


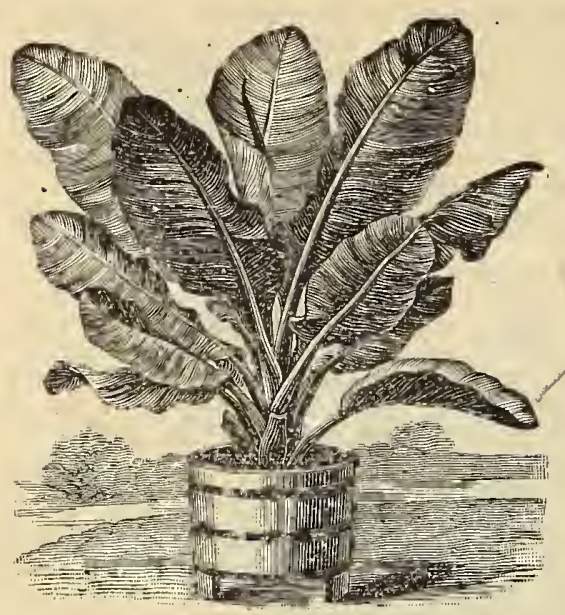

Musa Ensete.

MUSA ENSETE. Abyssinian Banana. A magnificent foliage plant with broad, massive leaves that grow to immense proportions; superb plant for the lawn; seeds sown early in heat will produce large plants the first season. Pkt.; 25 cents.

MIGNONETTE. Breck's Giant Machet. This strain is just what we have been asked to supply for a number of years - a largeflowered, bright-red colored, sweetly-scented, compact-growing, and free-flowering Mignonette. It is the selection of a florist who makes a specialty of Mignonette for market, and is superior to all other varieties for both pot culture and outdoors. The flowers are bright-red and feathery, the plants of compact, branching habit, and profuse. bloomers. Pkt., io cents.

NEMESIA STRUMOSA SUTTONI. This charming plant is undoubtedly one of the most charming annuals that has been introduced for a number of years. The color of the flowers is exceedingly variable, being white, ochreous. pale yellow, deep yellow, orange, orange scarlet, magenta, carmine, light rosy-purple, orange striped with orange-brown and shaded with mauve, etc., the throat being dotted with black on a yellow ground, and the outside is often veined and marked with purple. The variation in the color of the flowers is one of the most interesting features of this plant. The seed should be sown in pans or boxes filled with light soil, in March or April, and the plants put out-doors in May. They will come into bloom in June. Pkt., 25 cents.

WATER LILIES. From Seed. (Nymphaa.) Seed should be planted during March or April, in a teacup containing two or three inches of soil and filled with water. After planting, the cups should be placed in a temperature of from $70^{\circ}$ to $80^{\circ}$ during germination, which ordinarily takes ten days. When large enough to transplant, prick into small pots and place them in a pan of water deep enough to cover the pots about one inch. In June move to tubs or pools of water out-doors.

BLUE ZANZIBAR WATER LILX. (Nymphaea Zanzibarensis azurea.) Flowers varying from a light to a very dark, deep blue. The stamens of all are a

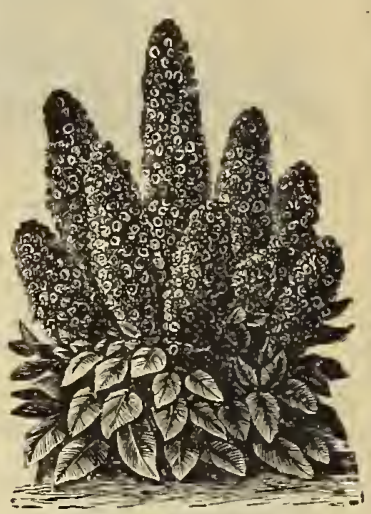

Breck's Mignonette. bright golden-yellow. The flowers open at about 7 A.M. and close about 5 P.M.

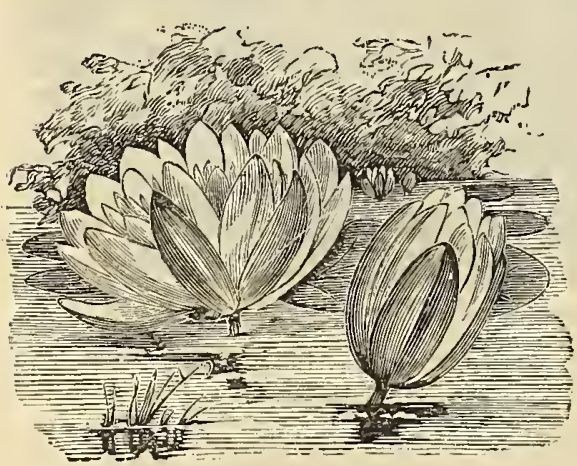

Nymphea.

NICOTIANA COLOSSEA. One of the finest annual ornamental foliage plants in cultivation. It may be grown in the same way as Nicotiana Affinis, and will attain a height of five to six feet in a season. The plants, which are exceedingly graceful, are furnished from the ground upwards with immense darkgreen leaves of great consistency, and of such robust growth as to withstand without injury high winds or storms. Valuable for planting either in single specimens or groups. Pkt., 25 cents.
RED ZANZIBAR WATER LILY. ( $N$. Zan, rosec.) Like above in every respect except color, which varies from rich pink to a deep rose, almost crimson in some specimens.

WHITE NIGHT-BLOOMING WATER LILY. ( $N$. Dentata.) This grand species opens its flowers at about eight o'clock at night, remaining expanded until noon the next day. They are pure pearly white, with petals expanded horizontally, so that the flowers are perfectly flat like a star. Each variety 25 cents per pkt., or three for 60 cents.

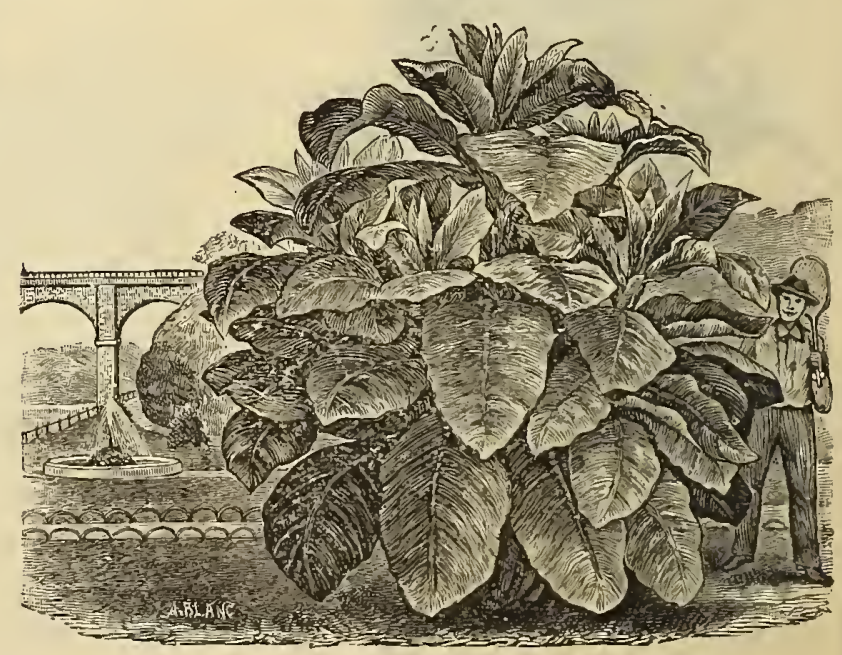

Nicotiana Colossea.

See Special Offers on third page of cover. 


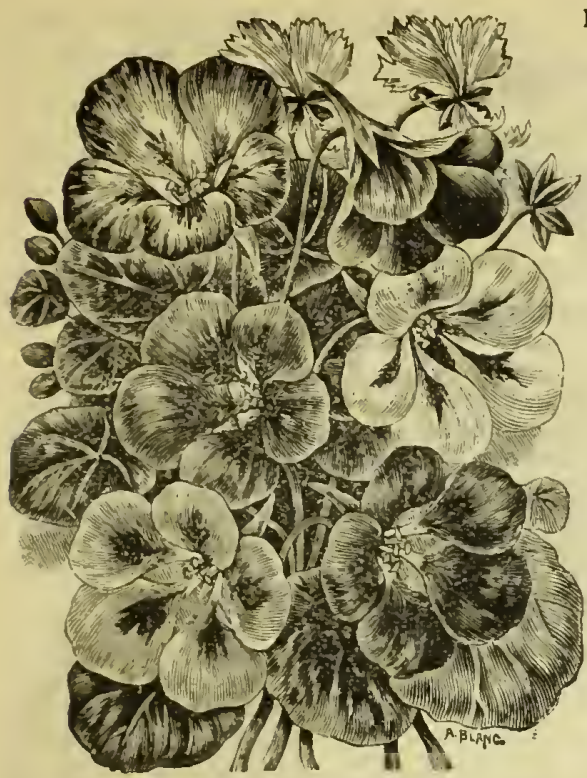

Divarf Nasturtium.

NASTURTIUMS. We call especial attention to our strains of Tall and Dwarf Nasturtiums. They have been grown for our own trade from the best stock seeds of the most noted and successful grower of this popular flower in the world, and are without equal. The demand for these superior selections the past two seasons has been greater than our stocks, though enormous, enabled us to meet, and the cause of the demand is demonstrated in the numerous letters sent us, setting forth in the most laudatory terms the superiority of o u $\mathrm{r}$ Nasturtiums over all others tried by $h$ undreds of writers. This year we have had grown for us a supply that we think will be adequate to the demand, and we solicit a trial order, and comparison of our Nasturtiums wit h the "best." For list of varieties see Tropeolums, page 77 .

PETUNIA. Double Prize, Large Flowering and Fringed. Petunias are again

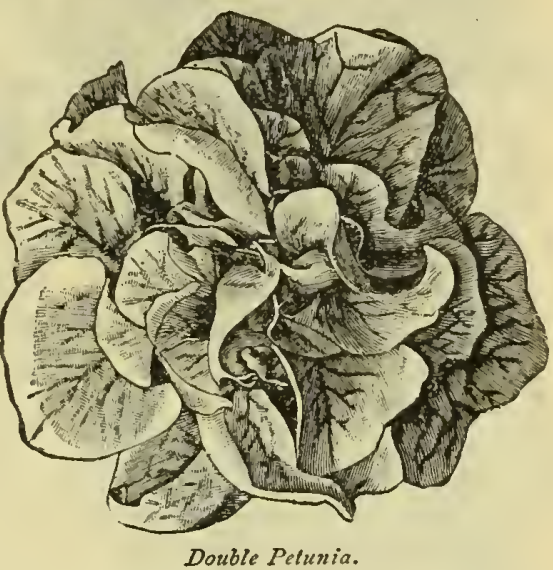

being received with marked favor, for bedding and as pot plants, much care having been given to their improvement during the past two or three years. We offer a very select strain of seed, saved from named double and fringed sorts, that will, we know, prove fully equal to the finest in this country. Pkt., 50 cents.

POPPY. White Swan. The plant grows only from one and a half to two feet high, forming a dense, iichly-branching bush, and above the same are elevated, on strong, slender stems, the very large flowers. The flower is of fabulous size, very double, laciniated, beautifully shaped, and of the purest possible white. The tume of blooming is of a much longer duration than that of the other Poppies. Pkt., 15 cents.

PAPAVER NUDICAULE COCCENEUM, fi. pl. Double flowering form of the bright orange-scarlet variety of the Iceland Poppy, producing about fifty per cent. of true plants with perfectly double flowers. The different varieties of this lovely Poppy are amongst the most attractive of early-flowering perennials, and have become great favorites everywhere. Pkt., 15 cents.

PAPAVER ALPINUM ROSEUM. A desirable new color of Alpine Poppy. The colors already in commerce are white, yellow and orange. This addition is a beautiful deep rose. Height and habit are the same as the class. Pkt., 25 cents.

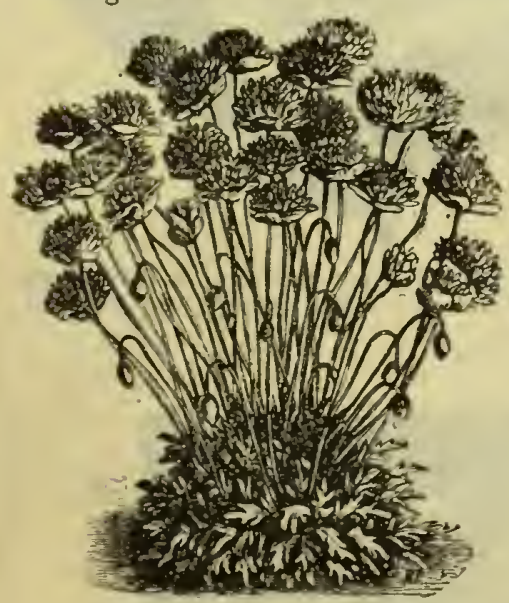

Papaver Nudicaule Cocceneum.

PAPAVER, THE SHIRLEY. Wilks' specialselection. The Shirley Poppy as introduced a few years ago gave general satisfaction, but already the strain has deteriorated and has a tendency to produce unattractive shades of red.

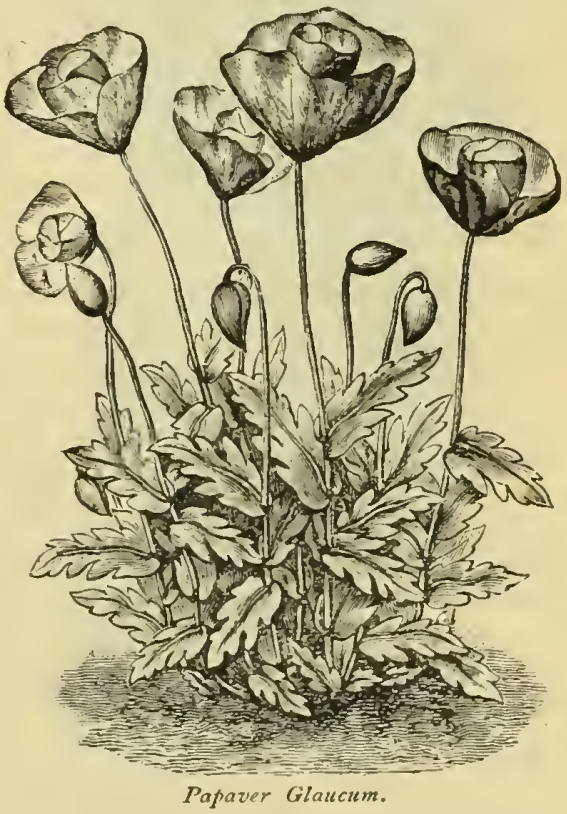

The originator has re-selected the varieties, and enabled us to offer seed exclusivelv composed of the softer and more delicate shades, mostly quite new, ranging from palest flesh to deeper pink and lilac, many being beautifully edged and striped. Pkt., 25 cents.

PAPAVER GLAUCUM. Tulip Poppy. A glossy new annual Poppy from twenty to twenty-four inches high, with beautifully shaped large flowers, four inches across, of a most brilliant dark scarlet. The two outside petals are doublc the size of the inner ones, and each pair forms by itself a round cup flower, which nearly resembles a single Tulip. The plant is always in full bloom during the summer. Pkt., 25 cents.

PAPAVER LAEVIGATUM. Very showy annual from Persia, with large fine-shaped Howers of a deep brilliant scarlet, with black spots, surrounded by a white margin at the base of each petal. Height, 2 feet. Pkt., Io cents. 


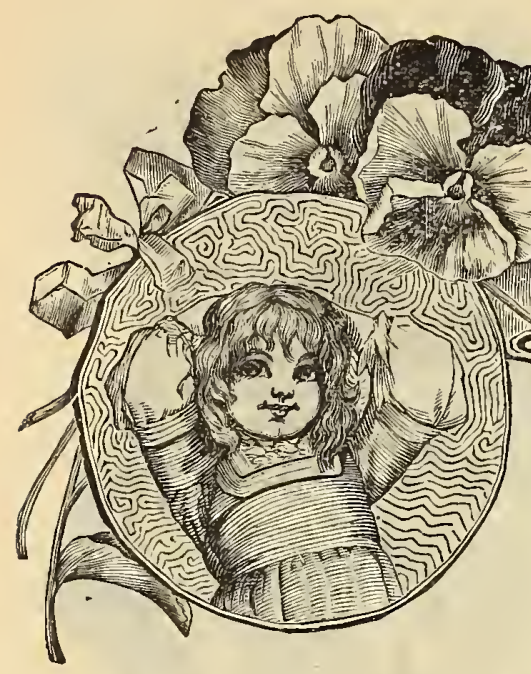

BOSTON PRIZE PANSIES. Among all the wonderful im. provements that have been made in old-fashioned garden plants, perhaps the Pansy stands out most conspicuously. Contrast the size, colors, and textures of the best strains of to-day with the tiny Heartsease from which they have heen evolved. To enthusiastic amateurs are we mostly indebted for the great change, and though they have not all PANSIES. 5 ? worked on the same lines they have been tending to the same end-improvement; and when all that has been accomplished is gathered together, no description could do justice to the result. Colors and shades not thought possible in Pansies, and never, until recently, dreamed of, are now to be had in endless variety. Beautiful blendings of Pompeian reds, claret, brick, garnet, and countless nameless combinations have been conjured into existence. The immense variety together with the satiny splendor of the large thick petals combine to make them a "joy forever. Such and even more is the Boston Prize strain of Pansies. All who have seen them have marvelled at their wondrous colors and robust growth; they embrace the very choicest and most delicate shades and blendings only from every collection of merit in cultivation in this country and in Europe. For two years they have gained every first prize offered for Pansies by the Massachusetts Horticultural Society and elsewhere when exhibited, against all comers. The supply of seed, which is quite limited, is entirely controlled by us, and will be purchasable only in packages sealed with our trademark. Pkt., 25 cents.

Relford's Prize. A superib cross-fertilized mixture of superior excellence, comprising some of the most lovely varieties of this favorite flower. The colors are brilliant and novel, dark violet, gold, blue, and white in eccentric variation of shades and markings, some striped, blotched, or flushed with red and bronze, also recommended for size and beauty of form. Pkts., 25 and 50 cents.

Canary Bird. A giant five-spotted variety on yellow ground. The ground color is a bright golden-yellow, each petal marbled with a large dark blotch. Pkt., 25 cents.

Cardinal. Roemer, the raiser of this new variety, says: "The idea of every pansy grower is to obtain a scarlet flower, and in the Cardinal I offer the nearest approach to that color yet attained. The ground color is brownish-scarlet, the three lower petals being marked with a dark blotch." Pkt., 25 cents.

Facock. So named because the beautiful ultra-marine blue contained in the upper petals of the flower most nearly resembles the peculiar shade of this color in the feathers of the peacock. Pkt., 15 cents.

Bulgian Blotched. Very choice. Pkt., 15 cents.

Bugnot's French. Famous French strain of fine robust growth; great variety of colors; the flowers are of great substance, and borne well above the foliage. Pkt., 50 cents.

Victoria Red. A brilliant blood-red variety, of fine shape and substance; very distinct. Pkt., 25 cents.

Breck's "International Prize," Mixed. Special mixture prepared by ourselves from the foregoing and other

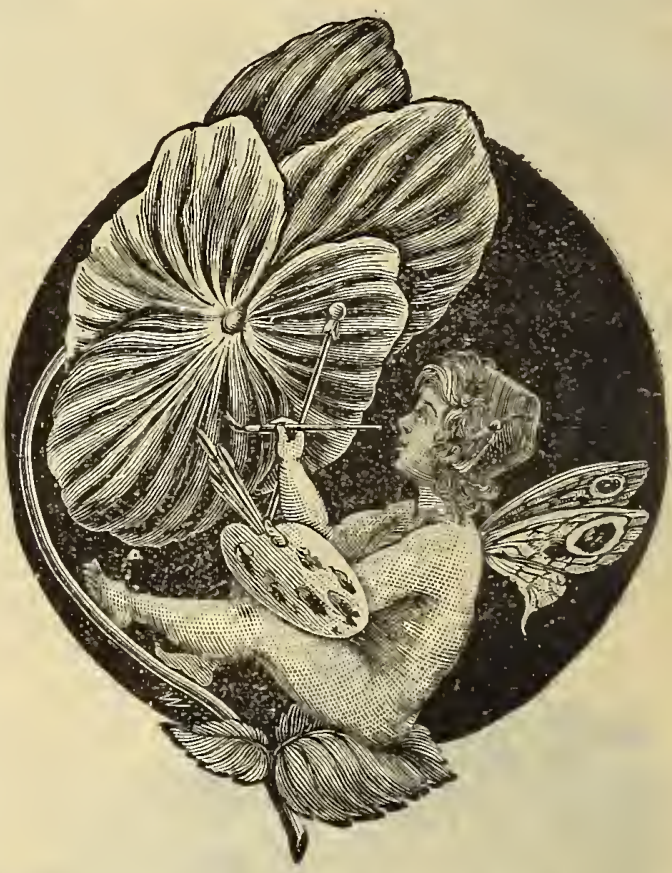
really choice strains. We think this well deserves the title "International," representing, as it does, the highest perfection attained by the "crack" growers of this favorite flower, both in Europe and America. Pkt., 25 cents.

For complete list of Pansies, see page 78 .

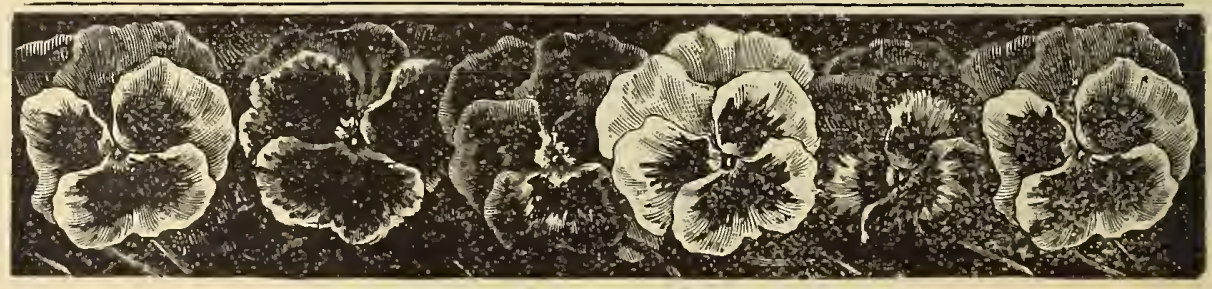

See Special Offers on third page of cover 


\section{SWEET PEAS. - Lathyrus Odoratus.}

HARVARD. If a moment's thought be given to the cause of popular names attaching to llowers, it will generally be found that a something in the flowers themselves suggests them. So it is with this new Sweet Pea. When we saw its blaze of beautiful deep crimson in the garden of the originator two summers ago, the Harvard color at once came to mind, and the name was adopted as being both descriptive and in keeping with the grand character of the flower. This variety commends itself to public favor, not by its color alone, which is in striking contrast to all other sorts known to us, but also by its immense size, profusion of flowers borne on long spikes, and delicate fragrance. The vines grow, under good cultivation, to a height of four fect, and produce lateral branclies in abundance. Its vigorous constitution seems to enable it to withstand our hot summers remarkably well. Grown along with over thirty other kinds last season, it showed greater endurance, and was a more persistent bloomer than any of them. We have pleasure in offering the Harvard to our customers, and feel assured its many desirable qualities will delight those who grow it. Every package of the genuine is sealed with our trade mark label. Per pkt., Io cents; Oz., 25 cents; $1 / 4$ lb., 75 cents.

Blushing Bride. This is the beautiful rose and white-flowered variety grown so largely by Boston florists. It surpasses everything yet offered in vigor of growth, length of spike, profusion of flowers, frcshness of color, and fragrance. Per pkt., 5 cents; oz., I5 cents; lb., \$1.5O.

\section{Eckford's Novelties for 1894.}

LADY PENZANCE. Pale, but very bright rose, very striking and distinct; a-most chaste and lovely flower

STANLEY. Deep maroon self, large, very handsome, distinct, beautiful tlowers, of the finest form and substance.

ROYAL ROBE. Deligate pink standards, the wings soft blush pink; a lovely flower; $2 \pi$ exquisite variety.

LADY BEACONSFIELD. Salmon standards tinted with rose, the wings pale yetlow, very distinct and beautiful.

Eacl of the above varieties, 50 cents per packet.

The following five varieties are the cream of Eckford's introductions for 1893 : )

Venus. Salmon bufi, the standards delicately shaded rosy-pink, very distinct. A most charming soft-tinted tlower. Pkt., 25 cents.

Blushing Beauty. Soft pink, suffused with lilac, a superb flower, distinct and lovely. Pkt., 25 cents.

Emily Eckford. A superb flower, of a well-marked cerulean tint, the standards suffused with reddish mauve; closely approaches a true blue; a desirable, large variety of good substance. I'kt.; 25 cents.

Firefly. A self-colored, intense, glowing crimson; good size and substance; a yery free bloomer. Pkt., 25 cents.

Gaiety. The standards white striped, and flaked with bright rosy lilac; the wings delicate blush; very distincl and beautiful. Pkt., 25 cents

Senator. A large, bold flower, finely-expanded standards, shaded and striped chocolate on creamy ground. Pkt., to cents; $0 z ., 25$ cents.

Princess Victoria. Standards, dark cerise, the wings mauve pink, and slight lines of rose. Pkt., Jo cents.

Primrose. A near approach to a yellow Sweet Pea, quite distinct in color, the standards ard wings pale primrose yellow. Pkt., io cents.; oz. 20 cents.

Countess of Radnor. Pale mauve standards, with a deeper shading of mauve; wings pale lilac. Pkt., 10 cents; $0 \%, 25$ cents.

Miss Blanche Ferry. An extra early sort, of dwarf compact growth, requiring no support, and produces beautiful pink and white flowers. Pkt., scents; oz., is cents.

Queen of England. A white variety of extra large size and good substance. Pkt., Io cents; oz., 25 cents.

Delight. Wings white, standards white, beautifully crested with crimson. Pkt., 1o cents; oz., 25 cents.

Splendor. Rich, bright, pinkish rose, shaded with crimson; a distinct variety. Pkt., ro cents; oz., 25 cents.

Apple Blossom. Bright, pinkish rose, wings blush; true apple-blossom color. Pkt., 1o cents; oz., 25 cents.

Boreatton. A very fine dark variety with bold flowers of great substance. The color is a rich, shining, bronzy crimson, with wings of a beautiful crimson purple, shaded with rose. Pkt., Io cents; oz., 25 cents.

Duchess of Edinburgh. Light scarlet, flushed with crimson, slightly marbled at the edge with creany white; wings light rose. Pkt., Io cents.; Oz., 25 cents.

Imperial Blue. Rich purplish crimson; wings bright blue; slightly shaded with mauve. Pkt., 10 cents; oz., 25 cents.

Isa Eckford. Beautiful creamy white, heavily suffused with rosy pink. Pkt., Io cents; oz., 25 cents.

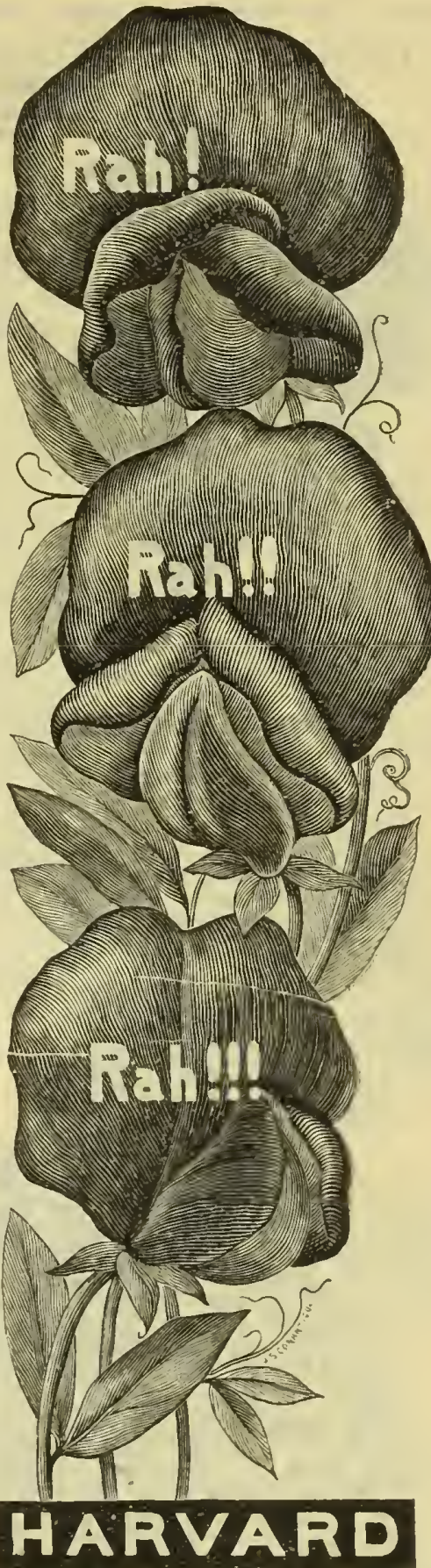


SWEET PEAS. - Orange Prince. Bright orange pink, flushed with scarlet; wings bright rose, veined with pink. Pkt., 10 cents.

The Queen. Light rosy pink; wings mauve. Pkt., to cents; oz., 20 cents.

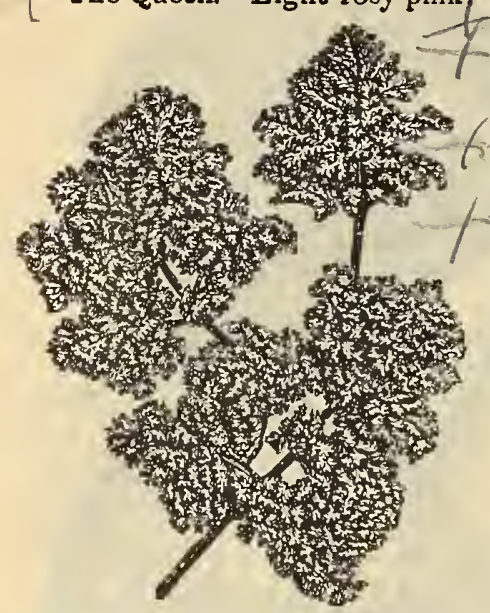

Pyrethrum Aurenm Cristatum.

Adonis. Bright rosy carmine. Pkt., 10 cents; oz., 20 cents.

Cardinal. Bright, shining crimson scarlet. Pkt., 10 cents; oz., 20 cents.

Eckford's New Mixed Sweet Peas. Saved from choice, named and unnamed varieties by this famous English grower. Plit., 10 cents; oz., 25 cents.

Invincible Carmine. Intense carmine crimson, large and brilliant. Pkt., 10 cents ; oz., 25 cents.

Indigo King. Dark maroon purple, with clear indigo-blue wings. Pkt., IO cents : oz., 25 cents.

For general list of Sweet Peas, see page 80.

PYRETHRUM AUREUM CRISTATUM. The originator says: "This unique novelty first made its appearance as a single plant in a bed of the ordinary Pyrethrum aureum, growing for seed in our grounds in $\mathrm{I} \$ 89$, and is now offered for the first time.

It is a beautifully curled-leaved form of the ordinary Golden Feather, and is in point of color equal to the very best type of the original from which it has sported, whilst the leaves have thecrisped appearance of the most exquisitely-curled Parsley.

The habit is extremely dwarf and compact, thus rendering it peculiarly useful for carpet bedding, edgings and similar purposes.

We have no doubt that in a few years it will become quite as popular as its prototype; it is, however, as might be expected from its dwarf habit and good color, a shy seeder, as in the case with all the extra good strains of Golden Feather. Packet, 25 cents.

\section{RICINUS ZANZIBARIENSIS (Mixed).}

Ricinus Zanzibariensis. The following varieties of Castor-OilBean, which we received from East Africa, represent an entirely new and distinct class. Having cultivated these plants in our trial grounds, we are pleased to state that we met with an unexpected success this very unfavorable season. The plants attained great dimensions, presenting a splendid aspect with their gigantic leaves, which surpassed in size and beauty all the species and varieties known hitherto. We do not doubt but that, as soon as these new Ricinus are introduced, the older

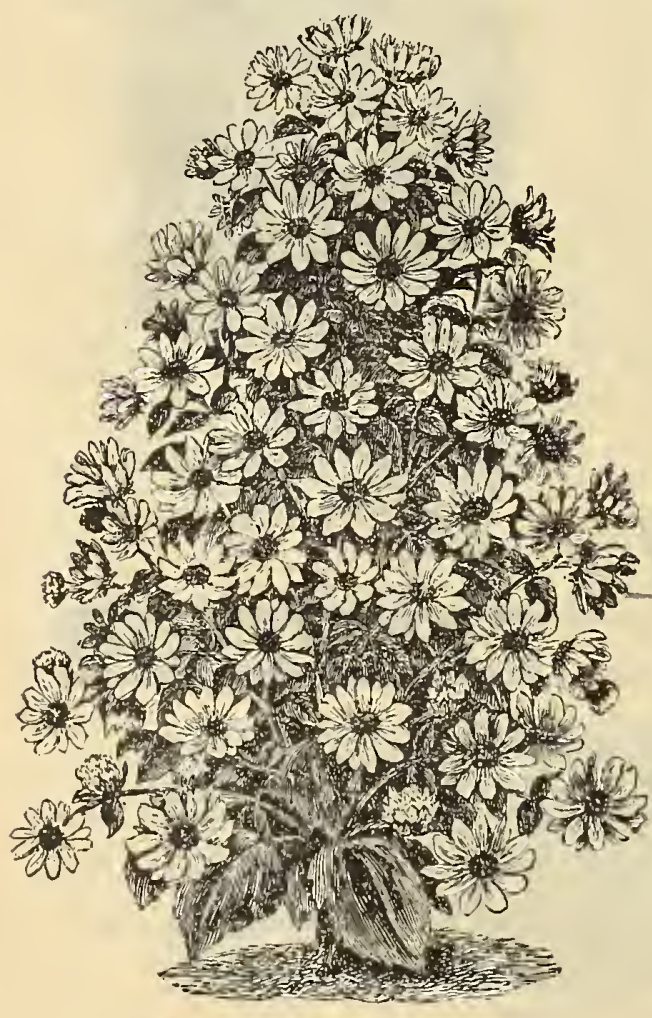

Suwfower, Lorenz's Milfowered. varieties will
soon disappear al to gether. The seeds also are very distinct, they are of a large size, and of new and exquis itive tints. The variety $\mathrm{n}$ a $\mathrm{m}$ ed above produces ligh t-green

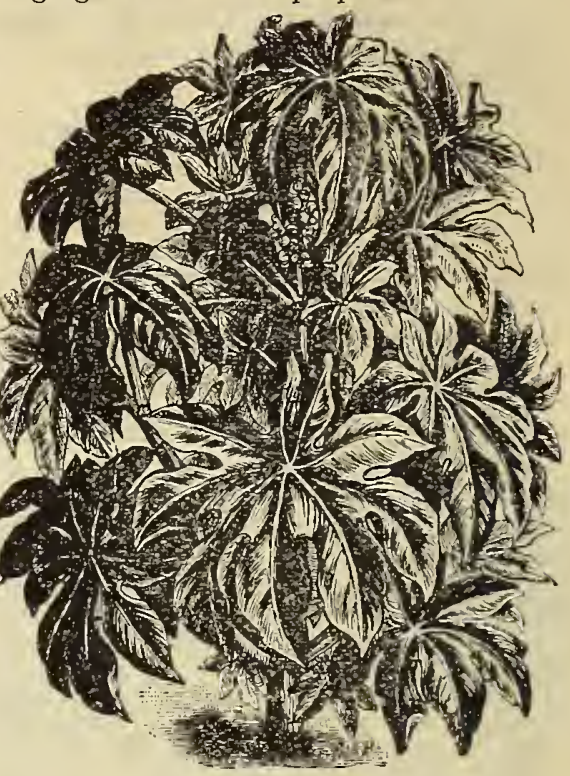

Ricinus Zanzibariensis.

leaves of 2 to $21 / 2$ feet across. The mixture embraces the following sorts, which are of similar growth to above, but differ in color, viz. :

R. Z. Maculatus. Leaves coppery-bronze, changing to dark green with reddish ribs.

$R$. Z. Cinerascens. Leaves brownish purple, changing into dark green, with lighter ribs.

R. $Z$. Niger. Leaves bronze, passing into dark green with reddish ribs. Per packet, each variety apart or mixed, 25 cents.

Sunflower, Lorenz's Milflowered. If planted singly in good soil this new Sunflower reaches the enormous height of from 12 to 15 , feet, and is richly branched from the base up to the top each branch bearing a multitude of mediunsize golden yellow flowers, with small black centre, which offer an invaluable material for bouquet and garnishing purposes. The best place for this new Sunflower will be to be planted singly on lawns, but also to cover naked parts in the garden no better material can be found. Packet, I 5 cents.

STOCK. Boston Florists, White. This variety will produce fine spikes of double-white flowers from January to December. Packet, Io cents; one-eighth of an ounce, 75 cents. 


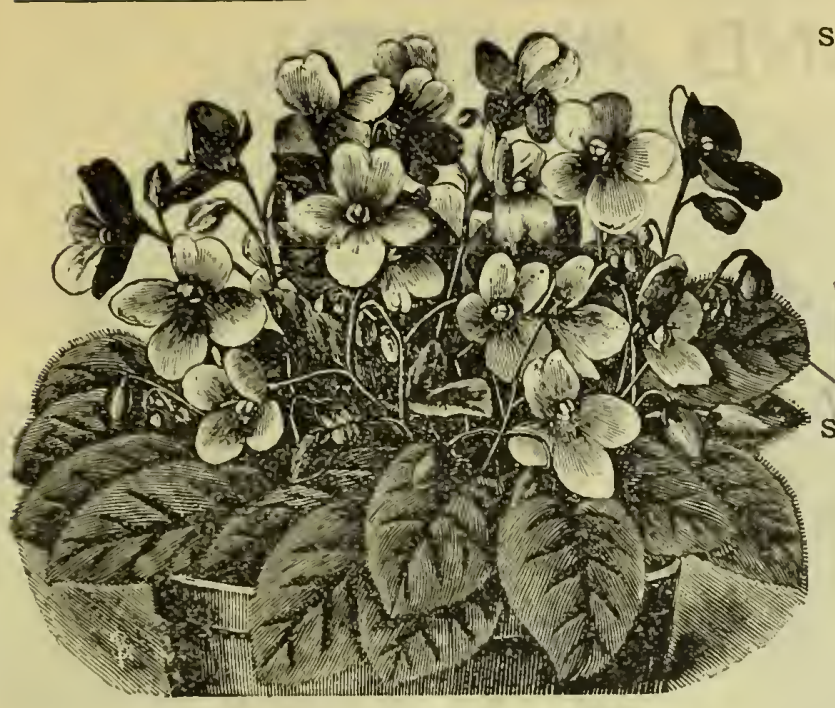

Saintpaulia Ionantha.

SAINTPAULIA IONANTHA. The leaves of this interesting novelty, which are darkgreen, of fleshy consistence and downy surface, spread themselves laterally just over the soil, and form as it were a rosette, in the centre of which spring up quite a bouquet of flowers, violet-like both in color and shape. but $1 \frac{1}{4}$ inches in diameter, and gracefully borne on stalks 2 to 3 inches high. These begin to appear whilst the plant is quite young and continue their display through the entire season. The seed is extremely fine and it requires similar treatment to Streptocarpus. Pkt., 50 cents.

STREPTOCARPUS. WENDLANDI. Cape Primrose. A magnificent new variety. The plant produces but one leaf, which attains a length of one and a half to two feet and a breadth of about one foot, the surface is a dark-green color, the underside purplish violet. The flower stems are produced at ihe base of the leaf and grow to a height of two feet. The flowers, which are borne in profusion dur. ing almost the whole year, are of a light-blue color and one to one and a half inches in diameter. Very valuable for pot culture. Pkt., $25 \mathrm{c}$.

NEW HYBRIDS. These are rather dwarfer in habit than Wendlandi, but are as profuse bloomers and have an abundance of leaves; the colors of the flowers are generally shades of blue and lilac. Pkt., 25 cents.

SCABIOSA GOLDEN YELLOW. After years of careful selection a pure yellow double Scabiosa has been

produced that comes true from seed. The plants of this pretty and useful novelty are semi-dwarfand bushy, and bear in great profusion, compact double flowers of a fine golden-yellow color, which are adinirably adapted for cutting. Pkt., 15 cents.

SCABIOSA ATROPUREA. Giant King of Blacks. The special recommendation of this new sort is its immense size; it is the largest flowering Scabiosa in existence; the flowers are long stemmed and of a deep blackish-brown. Pkt., 15 cents.

VERBENA. Mammoth Mixed. We have carefully selected and improved this fine strain for many years, and can recommend it as the very best in the market. The flowers are of the largest size and in the greatest variety of most brilliant colors. Pkt., 25 cents.

VERBASCUM PANNOSUM. A new species of the Thullein from Macedonia, that will prove useful for the mixed border, for planting in the shrubbery, or for grouping with other plants of remarliable size and form of foliage. The plants attain a height of about five feet, have leaves two feet long and eight inches wide, of lanceolate shape and thickly covered with

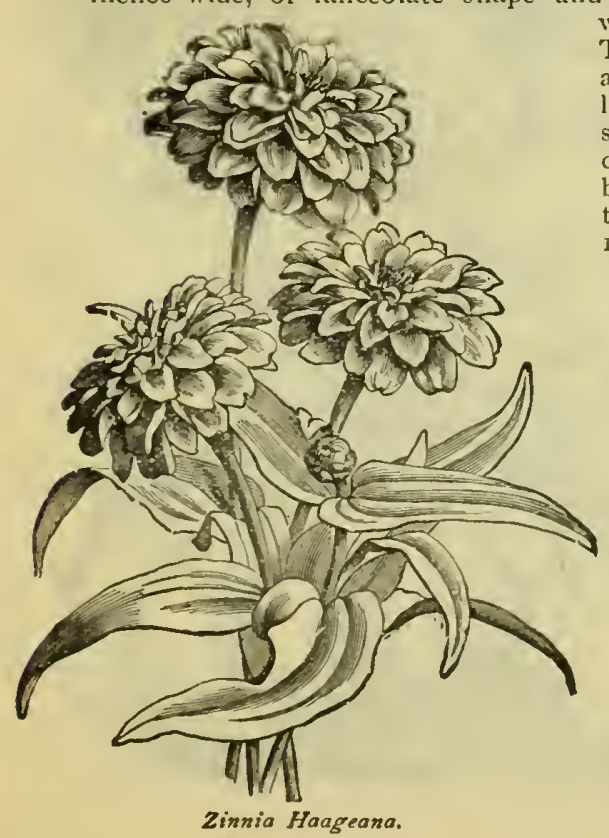
white woolly fibre. The flower stalks are about two feet in length, bearing large sulphur-yellow flowers densely set in their bracts. This introduc-

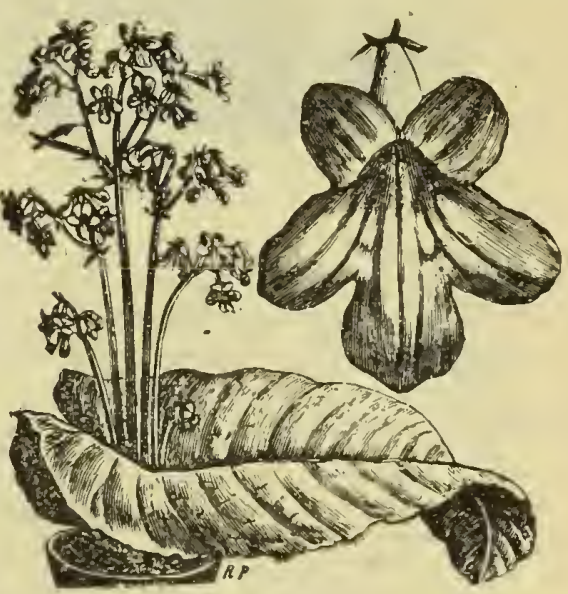

Streptocarpus. tion is recominended to all who are interested in perennials. Pkt., I5 cents.

ZINNIA ELEGANS, fi. pl. Tom Thumb. A new class of dwarf double-flowered Zinnias that attracted much attention at the grounds of the originator last summer. The plants. though dwarf, are very bushy, and are literally covered with sinall, very double flowers that embrace every color except the purple and hard shades of red. Pkt., 15 cents.

ZINNIA HAAgEana PUMILA, f. pl. A Toin Thumb Zinnia, but not of the Elegans type, which as dwarf sorts have never proved valuable. The plants of this, the Mexicantype, are of candelabra form, close and rigorous in habit and when fully developed only five to seren inches high, and are nearly covered with extraordinarily double flowers of an intense orange-yellow color. Each plant bears from 90 to 125 flowers, and continues in bloom throughout the season. Pkt., ro cents.

See Special Offers on third page of cover. 


\section{BULBS AND PLANTS.}

AMARYLLIS. Every one knows, and almost every one grows, a few of these lovely lily-like flowers, that appear in almost every shade of color ranging from pure white to deep crimson.

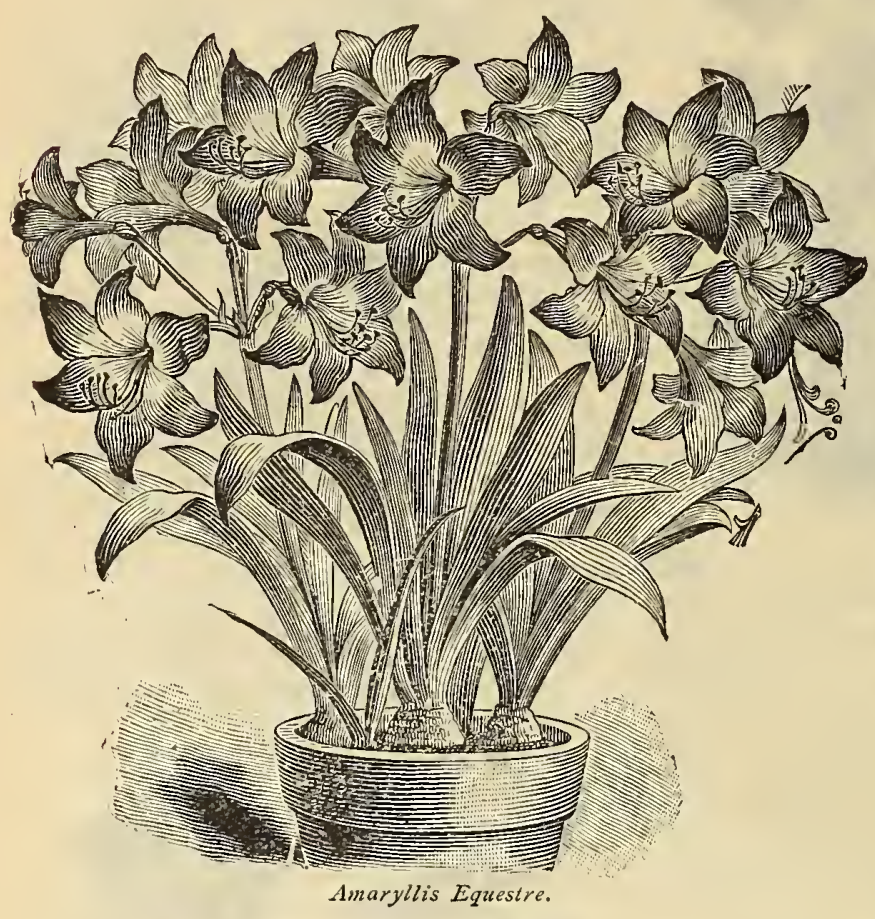

Atamasco. Pink and white, variable; showy for borders. I 5 cts. each; $\$ \mathrm{r} .50 \mathrm{per}$ doz.

Baffin. Large purplish-crimson flowers, beautiful in shape. \$1.25 each.

Formosissima. (Jacobean Lily.) Deep velvety-crimson; a general favorite. 20 cts. each; $\$ 2.00$ per doz.

Johnsonii. Crimson, striped with white; one of the very best sorts. $50 \mathrm{cts}$. each; $\$ 5.00$ per doz.

Lutea. (Sternbergia.) Showy yellow, autumn-flowering variety. $25 \mathrm{cts}$. each; $\$ 2.50$ per doz.

Vittata. Red and white grounds, beautifully peaked with many tints. $75 \mathrm{cts}$. each.

Vallota Purpurea. Crimson-scarlet flowers, in clusters of five or six. $50 \mathrm{cts}$. each; $\$ 4.00$ per dozen.

Zeyphranthes Rosea. Very fine, large flowers of a deep rose-color. Io cts. each; \$.oo per doz.

Zeyphranthes Treatea. (Fairy Lily). Pure white and deliciously scented. Io cts. each; 75 cts. per doz.

AMARYLLIS EQUESTRE. One of the most beautiful species in cultivation. The flowers open out flat, and are nodding, giving a graceful and attractive appearance when in bloom. The blossoms are borne in clusters which measure five or more inches across, and are briglit, sparkling orange-red, with a green and white star at the centre. $20 \mathrm{cts}$. each; $\$ 2.25$ per doz.

AGAPANTHUS. African Lily. Valuable for parlor or conservatory decoration. The flowers are borne in magnificent trusses that show to advantage against the glossy-green foliage.

Umbellatus. Blue, 50 cts. each. Umbellatus Albus Pure white, 5o cts. each.

APIOS TUBEROSA. A valuable hardy, tuberousrooted climber, closely resembling the common Wisteria in vine and foliage, and having clusters of rich, deep-purple flowers, which have a strong, delicious violet fragrance. They grow to a great height, and should be planted near a trellis, fence, tree or other place where you wish a climber. The bulbs are perfectly hardy and do not require to be taken up over winter. $20 \mathrm{cts}$. each; \$2.00 per dozen.

CRINUM ORNATUM. Probably no plant possessing so much grandeur as this is so little known. This is due to its great scarcity and high price. It is the king of the Amaryllis tribe; and we all know that that means a pretty fine thing. It produces a large round bulb, which grows to weigh as much as ten pounds. It rests in winter, and grows and blooms in spring and summer. It can be treated as a pot plant, or grown in the garden as a summer-flowering bulb. It is of the easiest culture, and sure to succeed with any one. Its flowers are large, and, like a most beautiful lily, borne in enormous clusters at the top of stout scapes. Color soft, delicate blush, with a pink bar through the centre of each petal, and very sweet-scented. Whoever possesses Crinum Ornatum has a treasure. Fine flowering bulbs, 50 cts. each.

See Special Offers on third page of cover.

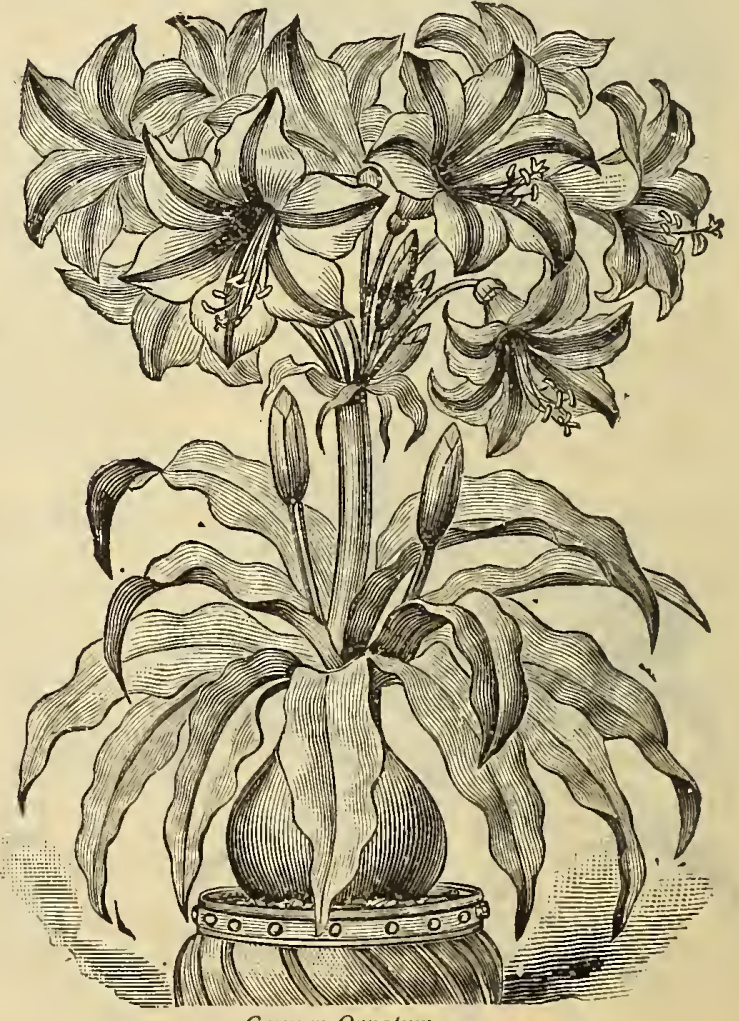

Crinum Ornalum. 


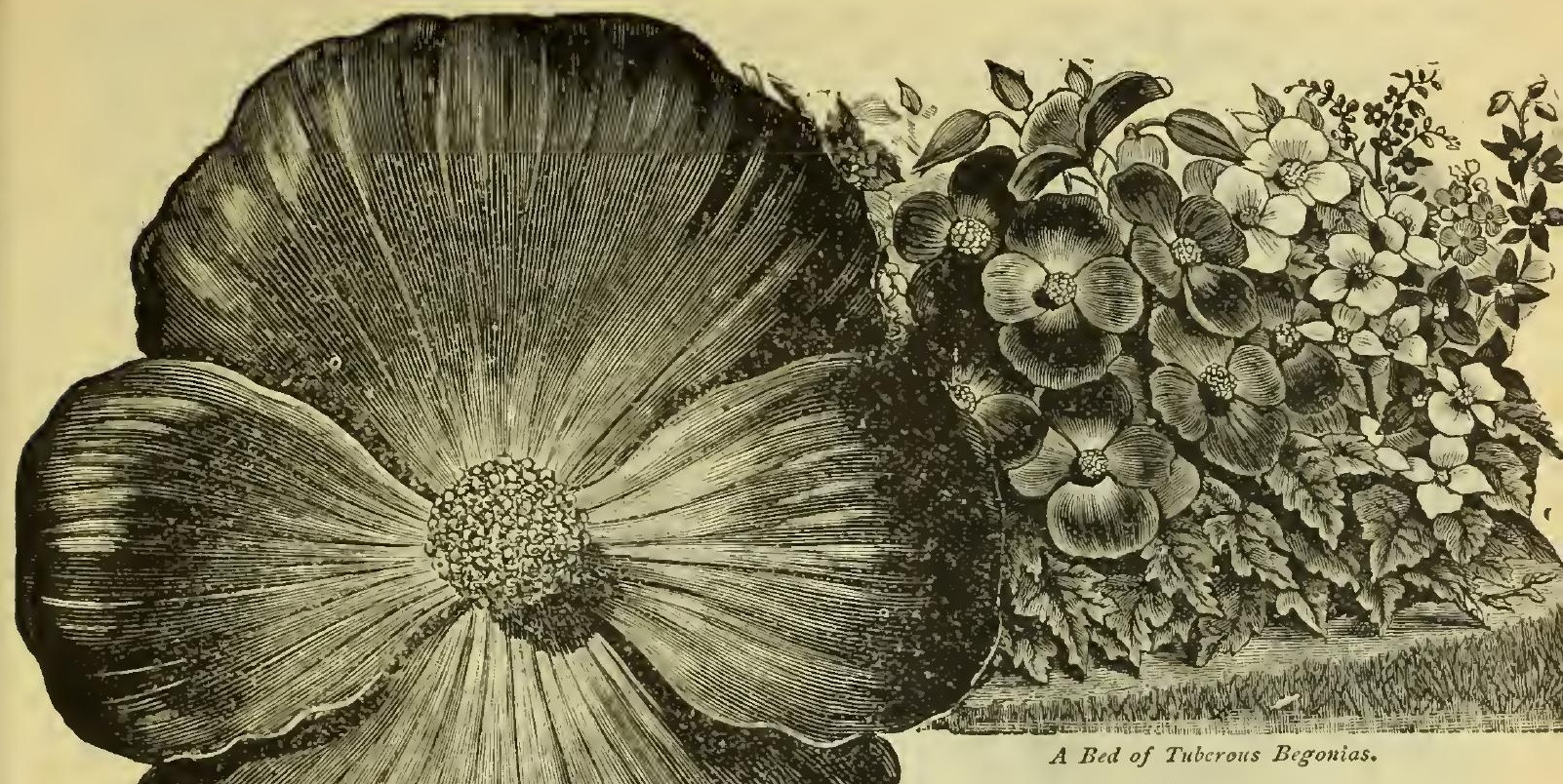

BEGONIAS. Tuberous-Rooted. No less

an authority than Wm. Falconer says

that as an out-door plant in the flower garden there is a bright future ahead of these tuberous-rooted Begonias. They grow well in shade or open sunshine. They are neat, bushy, and compact in growth and brilliant in blossom, without being harsh, garish, or obtrusive. Indeed, they fill a place unoccupied by any other fine flowering plant we cultivate in being rain-proof - rains don't knock oft or injure their flowers, and they afford us such a variety of color - white, yellow, rose, scarlet, and crimson in many shades. Some have drooping and some erect flowers; some have long, narrowish petals; others round and massive ones; and now double-flowered varieties are as abundant as we wish to make them. The bullss should be wintered in a cool and moderately dry place where frost won't touch them. Start them in boxes or pots during March or April, and plant out about the end of May. Give them plenty of water at the roots during dry summer weather, and they will delight you with their brightness and beauty until frost kills the foliage. The bulbs we offer are from the most noted English strain, and have been selected for uniformity of habit, height, etc.

BEGONIA. Single Mixed, 1o cts, each, $\$ 1.00$ per dozen; $\$ 8.00$ per hundred.

Single. Distinct Colors. White, Yellow, Pink, Salmon, Bronze, Crimson, Scarlet, etc., 15 cts. each, $\$ 1.50$ per dozen; \$11.00 per liundred.

Double Mixed, $25 \mathrm{cts}$. each, \$2.75 per dozen; $\$ 20.00$ per hundred.

Double, Distinct Colors. $30 \mathrm{cts}$. each, \$3.00 per dozen; $\$ 24.00$ per hundred.

BESSERA ELEGANS. This beautiful variety is the direct counterpart of Milla Biflora; rich and striking color, equalling it in graceful beauty. Pendulous clusters of bell-shaped flowers borne on long slender stems. The color is a striking shade of coral scarlet, with pure-white cups and dark-blue anthers. $S$ cts. each; 80 cts. per dozen.

CALLA LILY. "THE GEM." Richardia Nana. This is a novelty of great merit, and is highly recommended on account of its dwarf habit and free flowering. It resembles the common and popular Calla in all respects, except that it never grows higher than one and a half feet, and is more prolific of flower. We offer the true stock; there are others on the market. $50 \mathrm{cts}$. each; $\$ 5.00$ per dozen.

CALADIUM ESCULENTUM. Beautiful, ornamental foliage-plants. They grow in any good garden-soil to a height of five feet, and have leaves four feet in length by two and a half in breadth. First size, $15 \mathrm{cts}$. each; \$1.50 per dozen. Extra large, $25 \mathrm{cts}$. each; $\$ 2.50$ per dozen.

CYCLOBOTHRA FLAVIA. This golden gem is of great beauty and easily grown; the habit of plant and bloom is similar to Bessera; the color is clear golden-yellow, with intense black spot on each petal. $8 \mathrm{cts}$ each; So cts. per dozen.

CACTUS. These plants require absolutely no care. They grow for months in the house or garden without watering, and increase in value yearly". No wonder they are fast becoming "all the rage," for their flowers, which are of exquisite beauty and fragrance; ${ }^{*}$ and their curious forms render them exceedingly interesting. In winter they require scarcely any water. We send by mail 10 fine plants of blooming size, each one distinct and named. for $\$ 1.00$; or 5 for $50 \mathrm{cts}$. 
CANNAS. Large Flowering, French. During the past few years a great deal has been said and written about these new French Hybrid Cannas; yet they merit still more. Their beautiful tropical foliage alone is enough to commend them, but add to this their immense gladioli-like spikes of flowers that appear almost

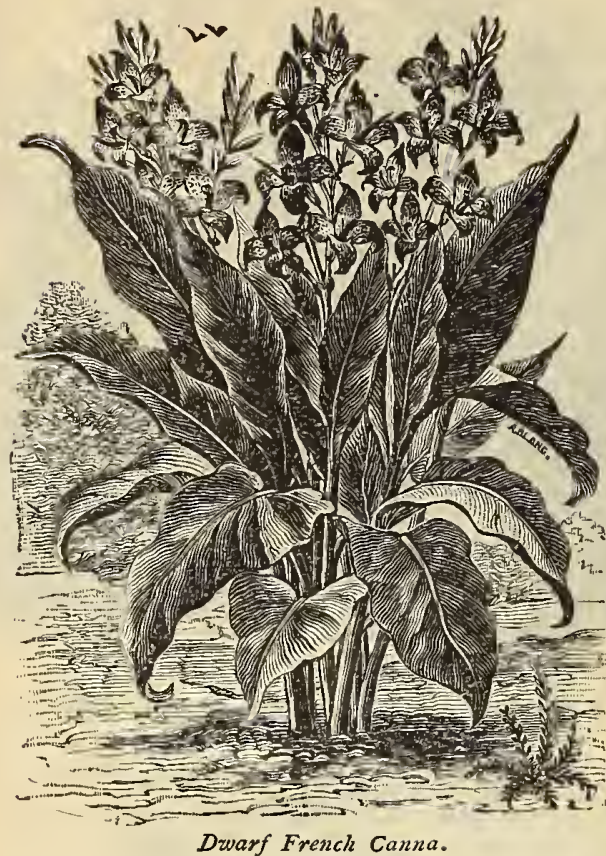

Francisque Morel. Foliage, dark green; height, $3 \mathrm{ft}$. Flowers, bright scarlet; height, $3 \frac{1}{2} \mathrm{ft}$.

F. Corbin. Foliage, dark green; height, $3 \mathrm{ft}$. Flowers, bright cherry-red; height, $4 \mathrm{ft}$.

Geoffry St. Hillaire. Foliage, chocolate color; height, $4 \mathrm{ft}$. Flowers, very large, deep-glowing, orange shade; height, $5 \mathrm{ft}$.

Jules Chretein. Dark-green foliage; height, $3 \mathrm{ft}$.

Flowers, bright crimson; height, $3 \frac{1}{2} \mathrm{ft}$.

J. Cardioux. Fine, dark foliage; height, $3 \frac{1 / 2}{\mathrm{ft} .}$ Flowers, brilliant cardinal-red; height, $4 \frac{1}{2} \mathrm{ft}$.

La Guille. Deep-green foliage; height, $3 \mathrm{ft}$. Flowers, beautiful, rich salmon-color; height, $5 \mathrm{ft}$.

M. Cleveland. Foliage, deep green; height, $4 \mathrm{ft}$. Flowers, orange scarlet, overlaid with crimson; height, $5 \mathrm{ft}$.

Madame Just. Dark-veined foliagẽ; height, $3 \mathrm{ft}$. The lower part of the petals is flame color, the upper part golden amber; height, $4 \mathrm{ft}$.

Madame Oriol. Bright-green, massive foliage; height, $2 \frac{1}{2} \mathrm{ft}$. Flower, orange red; height, $3 \frac{1}{2} \mathrm{ft}$.

Princess de Lusignaw. Dark, purply foliage; height, $21 / 2 \mathrm{ft}$. Flowers, orange scariet, shaded crimson; height, $31 / 2 \mathrm{ft}$.

Star of $18 \mathrm{gr}$. Bright-green foliage; height, $2 \mathrm{ft}$. Flowers, bright orange-scarlet color, faintly banded with yellow; height, $21 / 2 \mathrm{ft}$.

Souv de Charreton. Green foliage; height, $21 / 2 \mathrm{ft}$. Flowers, dazzling orange-scarlet; height, $31 / \mathrm{ft}$.

Vesuvius. Light-green foliage; height, $3 \frac{1}{2} \mathrm{ft}$. Flowers, crimson scarlet; height, $4 \frac{1}{2} \mathrm{ft}$.

Victor Hugo. Foliage, dark purplish-crimson; height, $3 \mathrm{ft}$. Flowers, deep orange-red; height, $4 \mathrm{ft}$.

Alphonse Bouvier. Strong green foliage; height, $5 \mathrm{ft}$. Flowers, crimson scarlet; height, $6 \mathrm{ft}$.' $20 \mathrm{cents}$ each; \$I.50 per dozen.

Madame Crozy. Massive deep-green foliage; height, $21 / 2 \mathrm{ft}$. The flowers are very large, of a dazzling crimson-scarlet, bordered with golden yellow; height, $31 / \mathrm{ft}$. 20 cents each; $\$ 1.50$ per dozen.

The above beautiful varieties, 15 cents each, $\$ 1.00$ per dozen, except as noted.

Canna Flaccida. This native variety is said to surpass in size and beauty many of the best French sorts. Its blossoms are from a rich golden-yellow to a pale straw-color, and over two inches across the narrowest way, and over five inches the widest way; height, $3 \mathrm{ft}$. 15 cents each; $\$ 1.25$ per dozen.

Cannas are not subject to either of our Special Offers. 
CHRYSANTHEMUM. Col W. B. Smith. A large double flower of the richest golden-bronze.

Emma Hitzeroth. A magnificent clear-yellow flower.

Edward Hatch. An immense flower, almost spherical in form; color soft lemon-yellow suffused with pink.

George W. Childs. A large reflex flower with broad, stiff petals; color deep, rich, velvety crimson.

Golden Wedding. Richest golden-yellow, intense and dazzling in color. "The flowers are of immense size.

Harry Barcley. A beautiful pearl-pink, semi-globular in form.

Harry May. Flower very large and double; color, deep old-gold.

Joseph $\mathrm{H}$. White. A large cream-iwhite, dahlia-like flower; one of the best.

Lillian Russell. A globular flower, Mermet-pink in color; a very pleasing variety.

Marguerite Jeffords. A large, fine, amber-colored ball.

Mrs. J. W. Morrisey. A mammoth flower; violetpink, quittéd petals.

Mrs. A. J. Drexel. Crimson; a very bright, attractive variety.

Mrs. Jerome Jones. Pure white, incurved Japanese. Awarded first prize at the New York, $\mathrm{IS}_{92}$, show, for the.best flower exlibited.

Strong plants of the above sorts ready about middle of April, 20 cents each; $\$ 2$ per doz.

Cullingfordii. Bright crimson, one of the best.

Eda Prass. Delicate pink; a fine flower.

Frank Thomson. White, shaded pearl-pink; strong grower.

Carry E. Widener. Bright yellow; flowers borne on stiff, stout stems: one of the best yellows.

Ivory. The best white in cultivation; early bloomer.

Kioto. Large yellow balls; a beautiful variety, and a great favorite.

L. Canning. A fine midseason; white, large and double.

Louis-Boehmer. Pink ostrich-plume Chrysanthemum; a delicate pink, petals covered with a hairy-like growth.

Mrs. Fottler. A delicate pink variety.

V. H. Hallock. Rosy pearl; waxy texture; a fine flower.

Violet Rose. Bright violet-shaded rose.

W. H. Lincoln. The best golden-yellow.

Strong plants of the above twelve sorts ready about middle of April, each 15 cents; $\$ 1.50$ per dozen.

HARDY CHRYSANTHEMUM. Golden Fleece. This is a valuable free-flowering, hardy Chrysanthemum, especially suitable for outdoor cultivation. The plant grows about two feet high, is bushy and symmetrically formed, and is literally covered from the beginning of July until severe frost with beautiful large golden-yellow flowers. The Golden Fleece should not be confounded with the common yellew garden Chrysanthemum that is pretty, though somewhat scraggy in appearance, and rarely blooms until about the time tlat frost cuts down all herbaceous plants remaining unprotected in the garden. Flowers of the Golden Fleece were shown at the Massachusetts I orticultural Society's Exhibitions the past season. Their beauty called forth most enthusiastic praise from all who viewed them. Price, $\mathrm{I}_{5}$ cents each; $\$ \mathrm{r} .50$ per dozen.

CLEMATIS PANICULATA. We cannot better describe this marvellously beautiful and fragrant climber than by the following, which appeared in a Boston dailv paper. September 19, I\$92. "This is the time of the full splendor of that wonderful climber, as yet quite new here, the Clemalis Paniculata. It covers some porches that the 'Listener' knows wol', with a white sheet of beautiful bloom, and fills the air all about with the most delicious perfume. It was introduced onlya few years ago, and its growth is so marvellously rapid, and its adaptation to our climate so complete, that it already threatens to reach the housetops. In a general way it resembles our common wild Clematis or Virgin's Bower, but its blossoms are more profuse and pure white, and exquisitely and penetratingly fragrant. It needs a trellis to grow upon. Of course it is an added recommendation to it that its flowers come in late September, when shrubs and climbers in bloom are rare. It is only one of about a million beautiful things, more or less, in nature and art, that we owe the motherland of gentleness and beauty, Japan." Plants, 5o cents to \$I each: \$5 to \$ro per dozen.

CYCLAMEN PEOSICUM GIGANTEUM. This magnificent strain of the favorite Cyclamen Persicum is the result of a long process of selection and high cultivation. The plants are very free flowering and produce blooms of extraodinary size and substance combined with great variety of color, remarkable at once for delicacy and distinctness. Fine plants, 75 cents each; $\$ 8.00$ per dozen.

See Special Offers on third page of cover. 


\section{DAHLIAS.}

This is one of the grandest autumn flowers we have. Set out in a sunny situation about the middle of May. The roots should be stored in dry sand in a warm cellar during winter.

\section{SELECTED, LARGE, SHOW DAHLIAS.}

All very fine, and quite distinct.

Beauty of Mirefield. Light maroon.

Dawn. White, shaded flesh color.

Fox Hunter. Scarlet; splendid.

John Greenaway. Maroon, shaded carmine.

Lucy Fawcet. Yellow, maroon blotched.

Mrs. Stancomb. Yellow, edged violet.

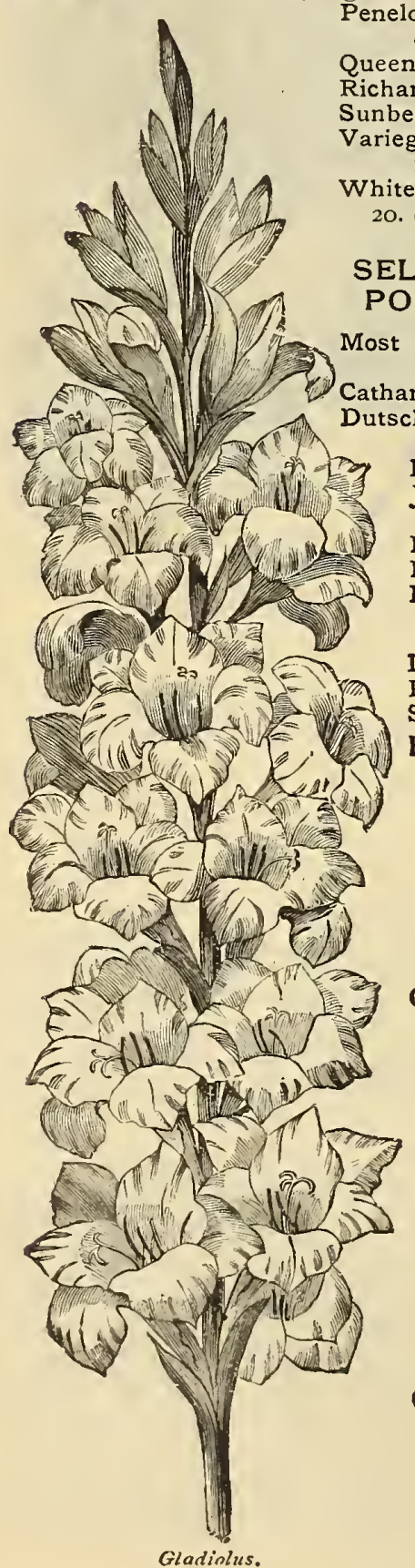

edged violet.

Queen Victoria. Yellow; splendid.

Deane. Violet maroon.

Bright amber. maroon.

White Bedder. Splendid white. 2o. cts each; $\$ 2.00$ per doz.

\section{SELECTED, DOUBLE, POMPON DAHLIAS.}

beautiful varieties; very distinct.

Catharine. Golden yellow.

Dutscher Coldmeteor. Amber, carmine, and yellow.

Eda. White, blotched yellow.

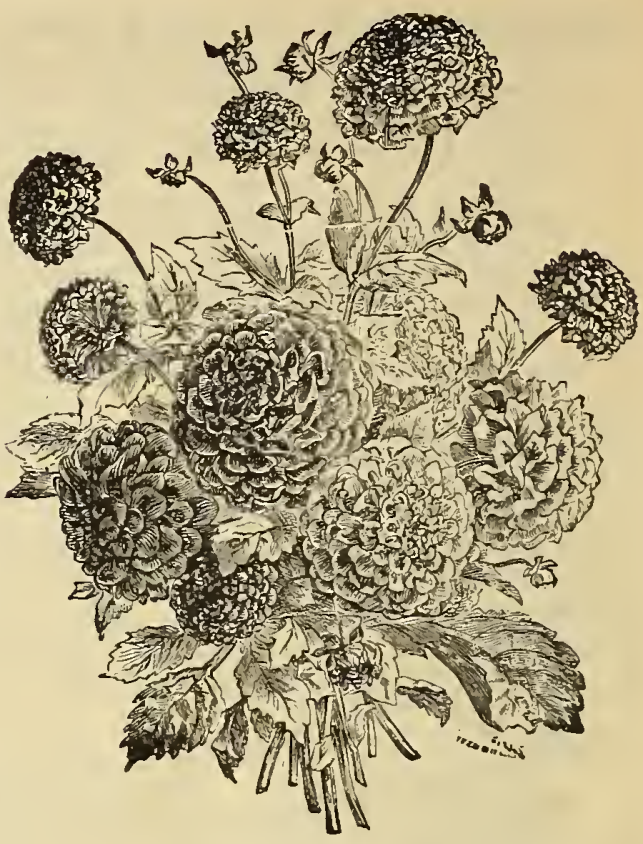

Double Pompon Dahlias.

Jessie Macmillan. Amber, blotched white.

Lady Blanche. Splendid white.

Little Duchess. Maroon; beautiful.

Little Gyp. Violet; extra. 20 cents each; $\$ 2.00$ per dozen.

Little Mabel. Amber.

Marguerite. Lilac.

Mlle. V. Faconet. White striped purple.

Rim of Go1d. Scarlet, yellow edge.

Sappho. Maroor, blotched white.

Double, Large-flowering sorts, distinct colors, named, $15 \mathrm{cts}$. each ; $\$ \mathrm{I} .50 \mathrm{oper} \mathrm{doz}$. Pompon or Bouquet, distinct colors, named, I $5 \mathrm{cts}$. each; $\$$ I.50 per dozen.

Single-flowering. Choice kinds, 15 cts. each; $\$ 1,50$ per dozen.

HARDY DAHLIA. Golden Ball. Although not really a Dahlia this plant bears so nuch resemblance to the family that we deem the name appropriate, and recommend it highly to our customers for planting in shrubberies or nixed borders; it is a perfectly hardy perennial and the roots do not require to be taken up annually, as is the case with Dahlias; the plants attain a height of four feet, are well furnished with pretty dark-green foliage, which in fall just shows through the almost complete covering of beautiful, double golden-yellow flowers that last till frost. Seeds, per packet, ro cents. Extra strong plants, each I5 cents; per dozen, \$1.50.

GLADIOLI. This valıable and easy cultivated class of bulbs is not half appreciated. They can be grown in beds or borders, and a succession of bloom can be kept up from June till frost by continuous planting.

Fine mixed varieties, $25 \mathrm{cts}$. per doz. . . . \$1.75 per 100

Named sorts, mixed,

Scarlet shades in mixture,

Crimson,

Pink,

White,

Yellow,

Striped and variegated,

French Hybrids,

30 "

3० "6

40 "

40 "

50 "

40

Lemoine's Hybrids, collections of ro named varieties, \$2.00.

Snow White. Under ordinary conditions, nearly the entire spike of this variety is a perfect paper white with a slight cream shade on lower end of petals; it is the best white Gladiolus grown. Each, $25 \mathrm{cts}$. ; per doz., \$2.50.

GLOXINIA BULBS. Our stock of this exquisite plant is very choice. The colors are so varied that they are difficult to describe, ranging from different shades of blue, purple, scarlet, pink, white, marbled, and spotted. The bulbs should be potted in the spring in light, sandy loam, and they will commence growing and blooming at once. In the fall, dry then, and store in a warm place through winter. Strong, flnwering bulbs. mixed colors, per bulb, 25 cts.; five for $\$ 1.00$; $\$ 2.25$ per dozen. 
HYACINTHUS CANDICANS. Perfectly hardy. Giows to a height of three feet and bears an abundance of pure white, bell-shaped flowers. Io cents each; 75 cents per dozen.

IRIS KAEMPFERI. When these are in bloom nothing in the garden is grander. 'The name "Poor-Man's Orchids" has been suggested for them on account of their ease of culture and great beauty. Think of a plant sending up to a height of three feet a dozen flower spikes, each spike bearing from two to four enormous blossoms eight to ten inclies across, and of the most delicate and beautiful colors, markings, and combinations. The Kaempferi is this and much more, for with all its beanty it is pefectly hardy. Choice named varieties, \$3,00 per dozen. Double and single mixed, \$2.50.

IRIS. GERMANICA. The German Iris bloom earlier than the Kaempferi, they embrace many charming combinations of colors, and are very fiagrant. Choice named varietics, $\$ 1.50$ per doz. Fine mixture, $\$ 1$ per doz.

IPOMAA NOCTIFLORA. Night-Blooming Moon-Flower. This beatiful climber has made a great sensation in floral circles since its introduction. Its pure white flowers open at dusk or earlier on cloudy days, at which time they are deliciously fragrant. 20 cents each : $\$ 2.00$ per dozen.

LILIES. Those who desire flowering plants that will, after planting, practically take care of themselves, find in this beatiful family almost everything desired. The Japanese sorts are in large demand, and maly be styled the cream of the list.

Lilium Auratum. Golden Banded Lily of Japan. Immense white flowers, each petal marked with a wide gold band and spotted with maroon. Each, 25 cents ; per dozen, $\$ 2.50$

Lilium Lancifolium Rubrum. White with rich crimson spots. Each, 20 cents; $\$ 2.00$ per dozen.

Lilium Lancifolium Roseum. White stained and spotted rose. Each, 20 cents; $\$ 2.00$ per dozen.

Lilium Lancifolium Album. Large pure white flowers. Each, zocents; per dozen, $\$ 3.00$.

MILLA BIFLORA. Beautiful, white waxy flowers with pale lemon anthers. Deliciously fragrant. Plant outdoors in May and take up bulbs in fall like Gladioli. Each, to cents; 75 cents per dozen; $\$ 5.00$ per hundred.

MADEIRA VINE. A beautiful rapid-growing climber, bearing in profusion very fragrant white flowers. Each 5 cents; per dozen, 50 cents.

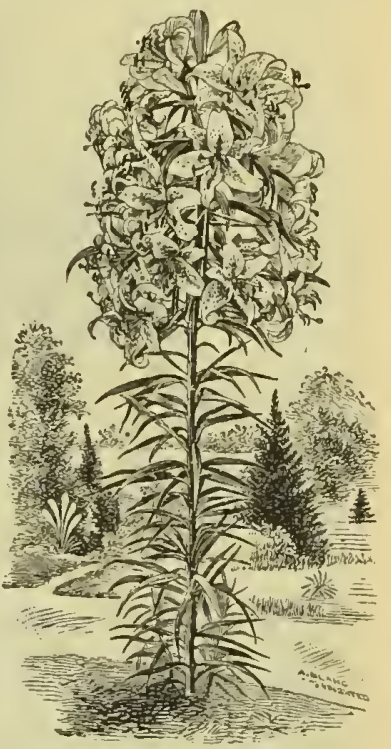

MONTBRETIA. Crocosmiaeflora Very large flowers of fine shape. Base of flowers is bright orange, sprinkled with purple spots, arranged like Tigridia.

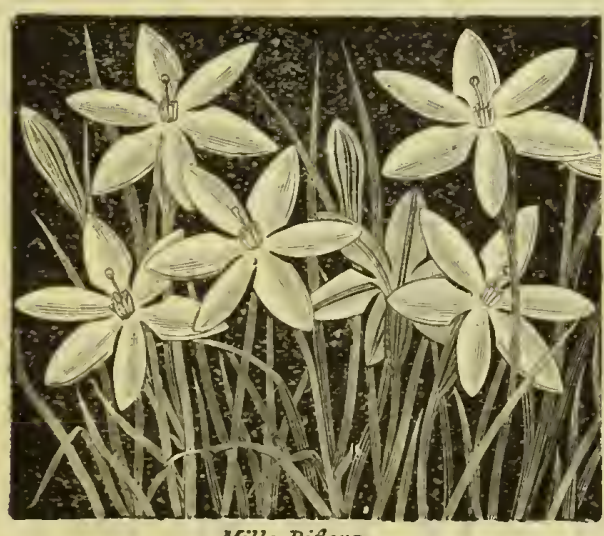

Milla Biflora.

Io cents each ; 75 cents per dozen.

NYMPHAA. The following are easily grown, valuable, and interesting aquatics. The sorts marked "T" are tender and the tubs or tanks in which they are grown out doors during the summer should be removed to a warm greenhouse in the fall, where they may be continued in bloom most of the winter. Those marked "HHI" are hardy south of Philadelphia; when planted north of there, they should have protection during winter. "The rari eties marked " $\mathrm{H}$ " are hardy, and may be grown in ponds, streams, or tubs.

Nymphæa Odorata "H." The well-known, white-flowered IVater Lily. Each 25 cents; per dozen, \$2.50.

Nymphæa Odorata Rosea "H." The Cape Cod pink water lily. Each \$1.00; per dozen, \$10.00.

Nymphæa Zanzibarensis "T." The finest of all the blue or purple sorts. The flowers often measure ten to twelve inches across. Each, \$5.00.

Nymphæa Zanzibarensis Azurea "T." Like the above, but with lighter-colored leaves and flowers. Each, \$2.00.

Nymphæa Zanzibarensis Rosea "T." The large pink flowers contrast prettily with the pale green of the leaves. Each, \$2.00.

Nymphæa Devoniensis "T." Flowers bright rosy crimson, eight inches or more in diameter; leaves a foot or more across, of a dark-green or coppery red, with dark red blotches. Each, \$2.50.

Nelumbium Speciosum "HH." The sacred Lotus of India. The leaves which grow at the time of blooming attain a height of about six feet. Another set, which is mostly made previously, floats on the sulface of the water. The flowers are white, deepening to a rosy-pink towards the tips of the petals. Each, \$2.50.

Nelumbium Luteum "HH." This American Lotus is in general appearance and habit similar to ${ }^{\prime}$. Speciosum, except that the flower is yellow; fragrant. Each, \$r.00.

Nymphæa Lotus "T." Supposed to be the Lotus of the ancient Egyptians. The flowers are white, cupshaped, with yellow stamens. Each, \$2.00.

See Special Offers on third page of cover. 


\section{TWWO GEMS. "NICHOLSON" and "ADA BYRON" CARNATIONS,}

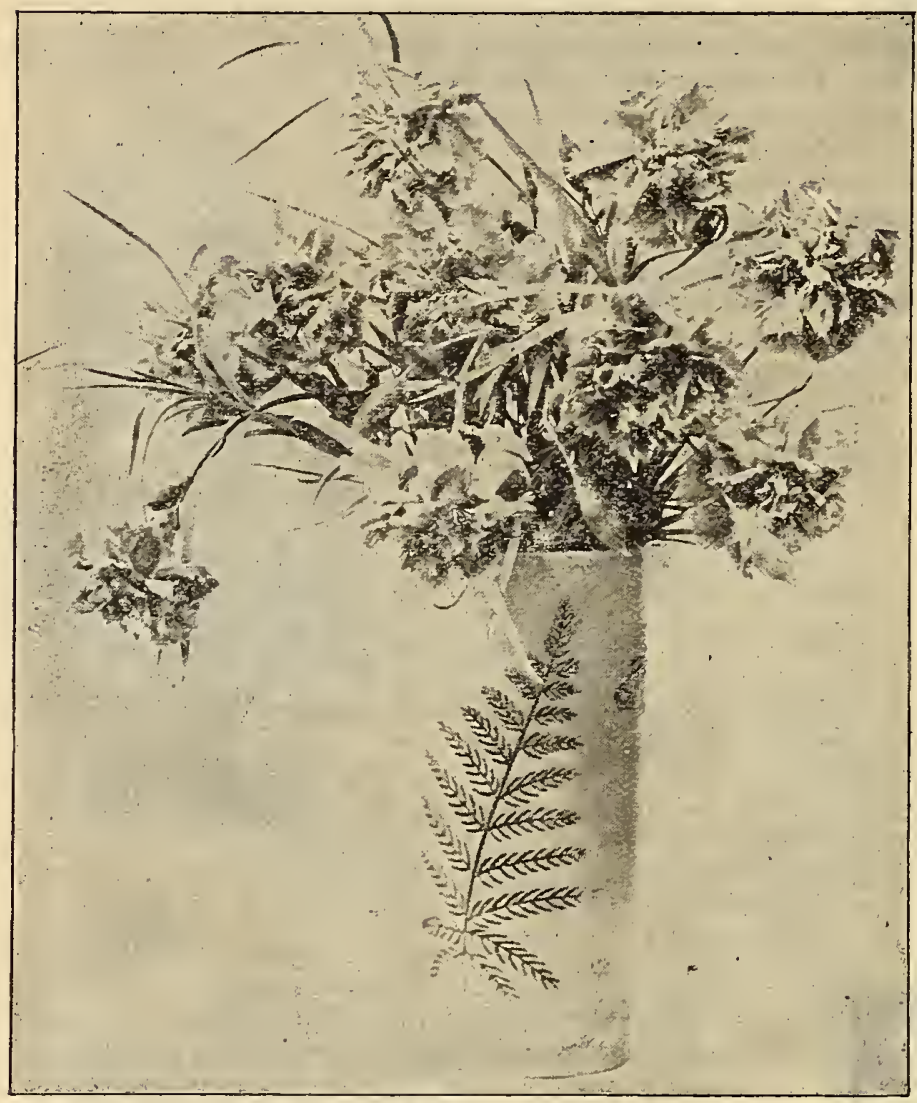

"Nicholson" Pink.

We are the ORIGINATOR'S SOLE AGENTS for the distribution and sale of these two new valuable Carnations; therefore to insure your obtaining them true to name, send your orders to us.

Just fancy a Carnation identical in color with, and almost as large as, a Mad. Gabriel Luizet Rose. You say it's hard to believe; nevertheless that is just what we have in the Nicholson. During the last few months when flowers of all kinds have been to some extent a drug on the market, this variety sold readily at highest prices; for instance, the "Florist's Exchange," of November 4,1893 , in reporting the condition of the Boston Flower Market, says: "The new Seedling Pinks from Mr. Nicholson, Ada Byron and Nicholson, are making great progress towards popularity. The demand is decidedly greater than the supply." And again, November 25, the "Exchange," says: "Whites sell for about \$1.00. Good colored ones bring $\$$ I.5O; Nicholson and Ada Byron, \$2.50." The demand at these prices speaks louder than words, and proves that these new seedlings are not seeking popularity simply because they are new, but rather on account of their merits. Many of the largest growers of Carnations in the United States and Canada have already placed their orders with us; and we believe no florist who consults his own interests, and is desirous of having the best. will allow this opportunity to pass him.

They were awarded FIRST-CLASS CERTIFICATES and FIRST PRIZES at the New York Show, the Massachusetts Horticultural Society's Show, and the Hampden County Horticultural Society's Show, November, 1893 .

\section{These Verdicts are Eloquent.}

All Carnation-growers who have seen the flowers, either on the exhibition tables or on the benches in the originator's greenhouses, have expressed but one opinion, which in short is - "ThesE BEAT CREATION."

\section{Nicholson.}

This is the largest, - often three inches in diameter, - brightest colored, most fragrant, - old clove-pink fragrance, - and most abundant bloomer produced to date. The plants are of exceedingly vigor. ous growth, and so far they have not been affected by rust or other disease. The flowers are borne in continuous profusion on long stiff stems, and a burst calyx is unknown among them. The foliage is very luxuriant, and of a pleasing bluishgray color.

Well-rooted plants, each 30 cts.; dozen, \$3.00; hundred,
FIRST CLASS
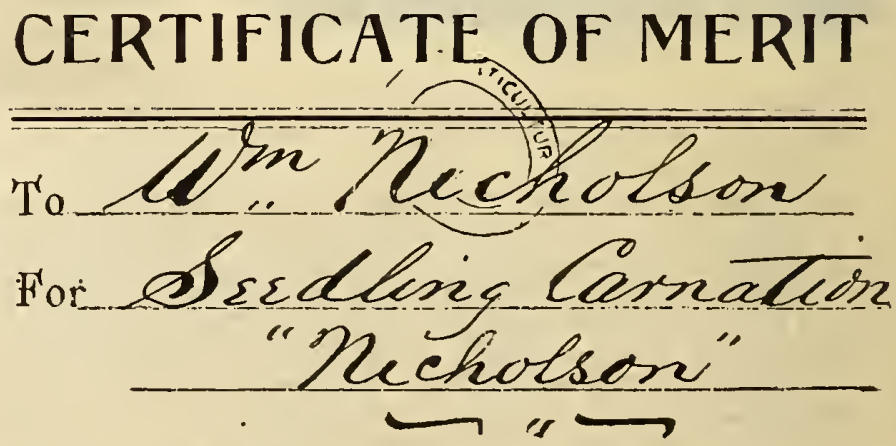

See Special Offers on third page of cover. 


\section{VADA BVRON CARNATION.}

A wonder in profusion of bloom, freshness of color, neatness of flower, length and stiffness of stem, and keeping qualities when cut. The flowers under fair cultivation average fully two inches in diameter, and are possessed to an unusual degree of the much-desired old-clove fragrance. They are of symmetrical form, nicely fringed, and of a more pleasing and even shade of pink than the much-extolled Grace Wilder. It is, however, from both a private and commercial grower's standpoint, in every way superior to Grace WVilder, and will meet with more appreciation in either the private greenhouse or market.

\section{Well-rooted Plants each, 25 cents; dozen, \$2.50; hundred, $\$ 12.00$.}

SHPMENTS of Ada Byron and Nicholson will be made on and after March J, iS94; all orders will be filled in the rotation received.

David Allan, Cliftondale, says: I visited the Mt. Pleasant greenhouses to see how Ada Byron and Vicholson looked when at home. I $\mathrm{am}$ satisfied they are the best varieties of their color, and Carnation-growers who fail to secure a supply of them will "miss it."

David Fisher, Montvale, writes: I consider Ada Byron and Nicholson Pinks the best of their color and varieties, that will be in great demand for private and commercial growing.

F. L. HARris, Wellesley, gives his opinion as follows: I have seen the two varieties of pinks originated by Mr. Nicholson, and consider them away ahead of anything yet produced.

T. D. HAtfield, Wellesley, recommends the Carnations Nicholson and Ada Byron as being superior to anything yet on the market, but has a decided preference for Ada Byron.

\section{Office of}

WELCH BROTHERS,

Wholesale Florists, Boston, Mass

Mr. Wm. Nicholson:

Dear Sir, - We would like z'ery much if you can by any possible means increase your shipments of the new Carnations ADA BYRoN and Nicholson. The demand for them is increasing to such an extent, both in this city and outlying districts, that the supply is allogether inadequate, even at the adianced price that we receive for them.

Amongsi the many new varicties that have appeared this or during the past three or four years we know of none that have received so favorable a reception from the retail trade.

Respectully yours,

(Signed) WeLCH BRos.

\section{CHRYSANTHEMUM.}

"MUTUAL FRIEND.". The following is a description as near as it can be giken on paper, but no words can properly convey an idea of its peculiar make-up and boldness, so different from any other known white; indeed, it is one of a thousand. A reflexed purewhite of good size, from 7 to $I I$ inches in diameter, great depth, no centre, stiff stems, heavy foliage within six inches of flower, great keeping qualities, easy of propagation, which is of great importance to the com-

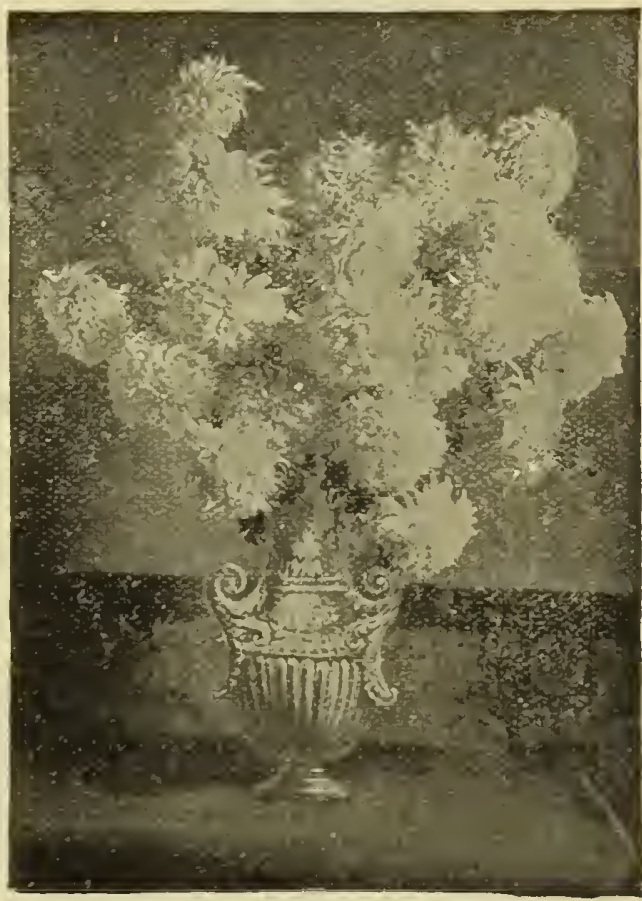

Chrysanthemum. Mutual Friend. mercial florist, blooms a week after Ivory in same temperature, and is of medium height. Each, 50 cents; dozen, \$5.50. Ready for delivery after March 1, 1894 .

VIOLET, LADY HUME CAMPBELL. The latest and best. Not quite so dark in color as Marie Louise but almost twice as large; well-grown flowers will easily cover a half-dollar piece. The lasting fragrance is as penetrating as it is delicate and pleasing, and the vigor of the plant is as noticeable in the foliage as in the flowers. The stock we offer has always been entirely free from disease of any kind. Per dozen, $\$ 1.00$; hundred, $\$ 6.00$. 


\section{FOLIAGE PLANTS FOR THE HOUSE.}

ARICA LUTESCENS. A majestic palm. Its dark, glossy-green leaves are gracefully curved on slender stems. The trunk and stems are a golden yellow, irregularly spotted with bronzy green. Each, I $1 / 2$ feet, $\$ 1.50 ; 21 / 2$ feet, $\$ 3.00$.

KENTIA BELMOREANA. Sometimes called the "Curly Palm," recognized as one of the best for all purposes, being able to withstand more ill usage, perhaps, than any other. Each, I $1 / 2$ feet, $\$ 2.00 ; 2$ feet, $\$ 3.00 ; 3$ feet, $\$ 5.00$.

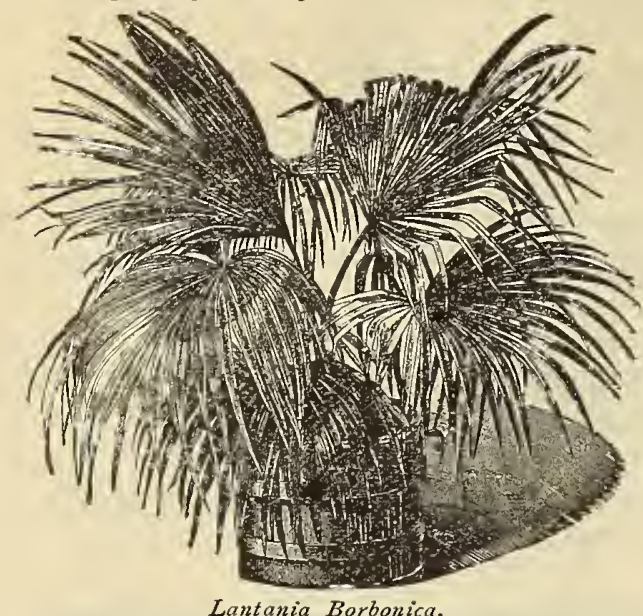

LANTANIA BORBONICA. This is a typical palm and is more largely used than any other. It is of strong, healthy habit, and especially suitable for window culture. Each, I $1 / 2$ feet, $\$ 1.50 ; 2$ feet, $\$ 2.00 ; 21 / 2$ feet, $\$ 3.00 ; 3$ feet., $\$ 5.00$.

PANDANUS UTILIS. This is a most desirable variety for window culture, and will bear without injury a great deal of neglect. Each, I foot, \$1.00; I 1/2 feet, \$2.50.

DRACENA INDIVISA. Valuable as a window plant and for centres of vases, baskets, beds, etc.; 50 cts. to $\$ 1.50$ each.

DRACENA TERMINALIS. A beautiful decorative plant, gorgeous shades of crimson, bronzy green and pink foliage; $50 \mathrm{cts}$. to $\$ \mathrm{I} .50$ each.

RUBBER PLANTS, Ficus Elestica. We can furnish nice, healthy plants of this favorite at from $\$ I .00$ to $\$ 5.00$ each, according to size.

NEPHROLEPSIS EXALTATA. Sward Fern. A very popular window-plant. It bears well with heat, dust, and neglect, and always has a bright, fresh appearance. Strong plants, 50 cts. to $\$ 2.00$ each.

\section{The Whitman Agricultural Works.}

JOHN W. MAY, President.

J. W. MITCHELL, Clerk.

DEXTER W. VERRILL, Treasurer.

\section{W. E. WHITMAN, Manager.}

INCORPORATED 1889.

MANUFACTURERS OF

FORMERLY AT WINTHROP, ME.

Horse Powers, Threshers, Sawing Nachines, Cider Mills, Feed Cutters, Wheelbarrow's,

Barrel Headers, and General Agricultural Nachinery.

Factory at Auburn, Me.

\section{Joseiph Breolk de Solns,}

Selling Agents.

In announcing that we have accepted the selling agency of the above concern, we take much pleasure in informing our customers that we have dealt with the Whitmans, father and son, between fifty and sixty years, during the last twelve years of which time our dealings have been with Mr. W. E. Whitman, and we cannot call to mind an instance where his word has not been as good as his bond. This old and honorable business was established in 1834 , at Winthrop, Maine, by Luther Whitman, and was successfully run by him and his sons without a break from that date until their disastrous fire in I $\$ 87$ wiped it out. The citizens of Auburn, Maine, believing it for their interest to have the new works located in their town, offered many inducements, and as the shipping facilities were better than at Winthrop, the company decided in favor of locating at Auburn, where the works are now established.

The principal products of the Whitman Agricultural Works are Horse Powers, Threshers, Sawing Machines, Cider Mills, Feed Cutters, Wheelbarrows, Barrel Headers, and General Agricultural Machinery.

In addition to the above the company is prepared to make contracts for the manufacture of any new or novel articles in this line. As their agents we solicit correspondence, will furnish estimates, and are prepared to offer exceedingly low prices for large orders for export.

\section{JOSEPH $\underset{\text { (Corporation) }}{\text { BRECK }}$ \&ONS,}

Selling Agents of the Whitman Agricultural Works.

See Special Offers on third page of cover. 


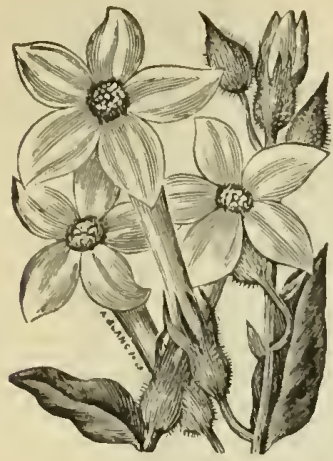

NICOTIANA.

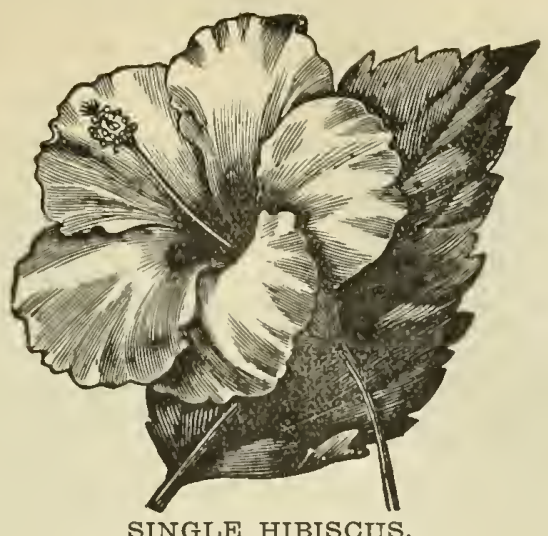

SINGLE HIBISCUS.

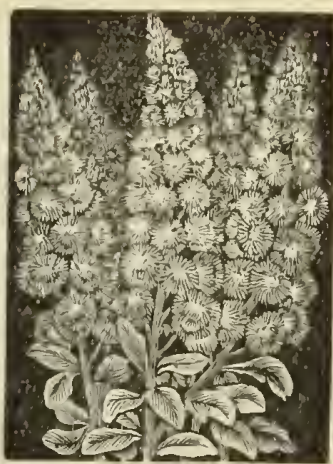

MIGNONETTE.

NAME.

DESCRIPTION.

LOBELIA. Erinus Compacta Oculata, dark blue, with white eye

" " Crystal Palace, compact growth, with rich blue fiowers

" Gracilis, celestial blue

“ Emperor William, compact variety, sky-blue flowers .

" Paxtoniana, pure white, with sky-blue belt

" Prima Donna, flowers velvety maroon.

Ramosa Compacta, dark blue, compact

Cardinalis Queen Victoria, brilliant scarlet

Hybrida, mixed, all colors

LOPHOSPERMUM. See Climbers,

LOVE IN A MIST. See Nigella.

LOVE LIES BLEEDING. See Amaranthus Caudatus.

LUNARIA. (Honesty.) Splendid border plants; its seed-pods are valuable for winter bouquets; flower purple.

LUPINUS. A splendid genus of ornamental, beautiful, and free-flowering garden plants, witl long, graceful spikes of pea-shaped blossoms.

Affinis, blue, white, and purple

Albo Coccineus, rich, rosy red half way of the spike, then pure white to the apex .

Nanus, dwarf blue, very fine, extra for bedding

Polyphyllus, mixed, blue and white

" A nnual, mixed, variety of colors

LYCHNIS. A genus of handsome and highly ornamental plants of easy culture; strikingly effective in mixed flower and shrubbery borders.

Chalcedonica, scarlet .

" Fulgens, bright orange scarlet

Haageana Hybrida, mixed, brilliant orange scarlet, crimson, etc.

LYTHRUM. Profuse-flowering plant, with rosy purple flowers.

Roseum Superbum (see above description)

MALOPE. Handsome plants, of a branching habit, producing thetr large flowers in great profusion; very effective in mixed borders.

Grandifiora Purpurea, purple

\section{" " Alba, white}

MALCOMIA. (Virginian Stock.) Profuse-flowering plants, effective in beds, baskets, or in edgings. Mixed

MALVA or MALLOW. Showy and free-flowering border-plants, succeeding in any conmon garden soil.

Crispa (Curled Mallow), ornamental foliage, tall

MARTYNIA. Handsome, free-flowering plants, flowers as large and handsome as.Gloxinias, succeeded by curious, double-horned fruit.

Mixed colors

MARIGOLD. See Tizgetes and Calendula.

MARGUERITE. See Chrysanthemum Frutescens.

MARVEL OF PERU. See Mirabilis.

MATHIOLA. (Stocks or Gillyflower.) One of the popular, beautiful, and important garden favorites, for bedding, massing, edging, ribboning, or pot culture. It is unsurpassed either for brilliancy and diversity of color, or profusion and duration of bloom.

German Dwarf, Ten Weeks, bright colors, mixed " large Flowering, Ten Weeks, Bright Crimson

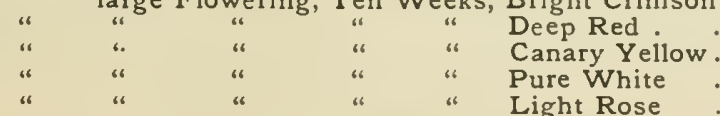

See Special Offers on third page of cover. 
NAME.

MATHIOLA. German Large Flowering, Ten Weeks, Mixed varieties, extra fine " Early Autumn Flowering or Intermediate, finest mixed, all colors " East Lothian or Autumn, choice mixed

" Emperor or Perpetual, finest mixed

"Winter or Brompton, extra mixed

Bicornos. (Evening Scented Stock)

MATRICARIA. (Double Feverfew.) Handsome, free-flowering ornamental plants, fine for bedding or pot culture.

Capensis, dwarf, double, white, very fine

Exima Grandiflora, an improved pure white variety, very double

Nana, f. pl., a dwarf variety, with double white flowers,

MAURAN DYA. See Climbers, useful for bouquets

MESEMBRYANTHEMUM. - A brilliant and profuse-flowering tribe of dwarf-growing plants, effective in beds, edgings, rock-work, rustic baskets, or vases in warm, sunny situations; fine for pot culture.

Crystallinum (Ice Plant), prized for its peculiar glistening foliage, white

Tricolor (Dew Plant), rose, purple centre

Fine mixed, all colors

Album, white

MICHAELMAS DAISY. See Perennial Aster.

MIGNONETTE. See Reseda.

MIMOSA. (Sensitive Plant.) Very curious and interesting plant, its leaves closing if touched or shaken.

" Pudica.

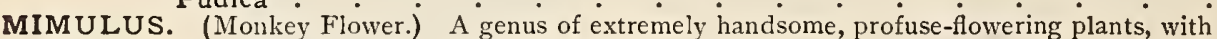
singularly shaped and brilliantly colored flowers.

" Cardinalis, mixed, all colors

“ Cupreus Duplex (Hose in Hose), double tiger spotted

" " Nanus, richly marked, bright colored flowers

" Moschatus (Musk), sweet-scented, yellow flowers

" Roezlii, bright yellow, spotted with crimson, fine for bedding

Tigrinus Grandiflorus, mixed, beautifully spotted, all colors .

MIRABILIS. (Marvel of Peru or Four O'Clock.) Few plants combine so much beauty, both of foliage and flowers, as this handsome genus: the roots may be preserved through the winter.

“ White, sweet-scented

Fine Mixed

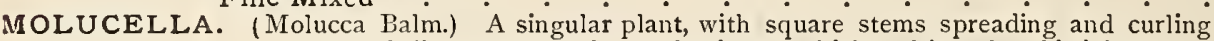
upward like the arms of a candelabrum, which end in tufts of bright leaves and tiny cups of pea-green color, veined with whitish green; within the calyx a button-shaped bud appears, which unfolds into a flower formed like a shell, of a white and purple color, very curious.

MOMORDICA. See Climbers,

Lævis (Shell Flower). . . . . . . . hA

MONKEY FLOWER. See Mimulus.

MONKSHOOD. See Aconitum.

MORNING GLORY. See Climbers,

MOURNING BRIDE. See Scabiosa.

MORNING GLORY, DWARF. See Convolvulus Tricolor.

MUSK. See Mimulues Moschatus.

MYOSOTIS. (Forget-Me-Not.) Charming little plants, very popular, producing their beautiful, star-like flowers in great profusion; invaluable for spring garden decoration.

Alpestris, mixed

" Alba . Carulea, bright blue

Azorica, blue, shaded purple Alba, pure white

Palustris, blue, with white eve

Palustris Semperflorens, dwarf, a beautiful azure-blue, continues in bloom until frost; does well in moist and shady situations.

Palustris Semperflorens Alba, white Mixed

MYRSIPHYLLUM. See Seeds for Greenhouse,

NASTURTIUM, DWARF. See Tropaolum Nanum.

NASTURTIUM, TALL. Sie Climbers,

NEMESIA. One of the prettiest free-blooming plants, adapted for beds, edgings, rock-work, or pot culture.

Finest Mixed Varieties

NEMOPHILA. Charming dwarf-growing annuals, with neat, compact habit of growth, and colors strikingly beautiful.

Best Varieties, mixed.

NEW ZEALAND PAMPAS GRASS. See Ornamental Grasses, page 78 

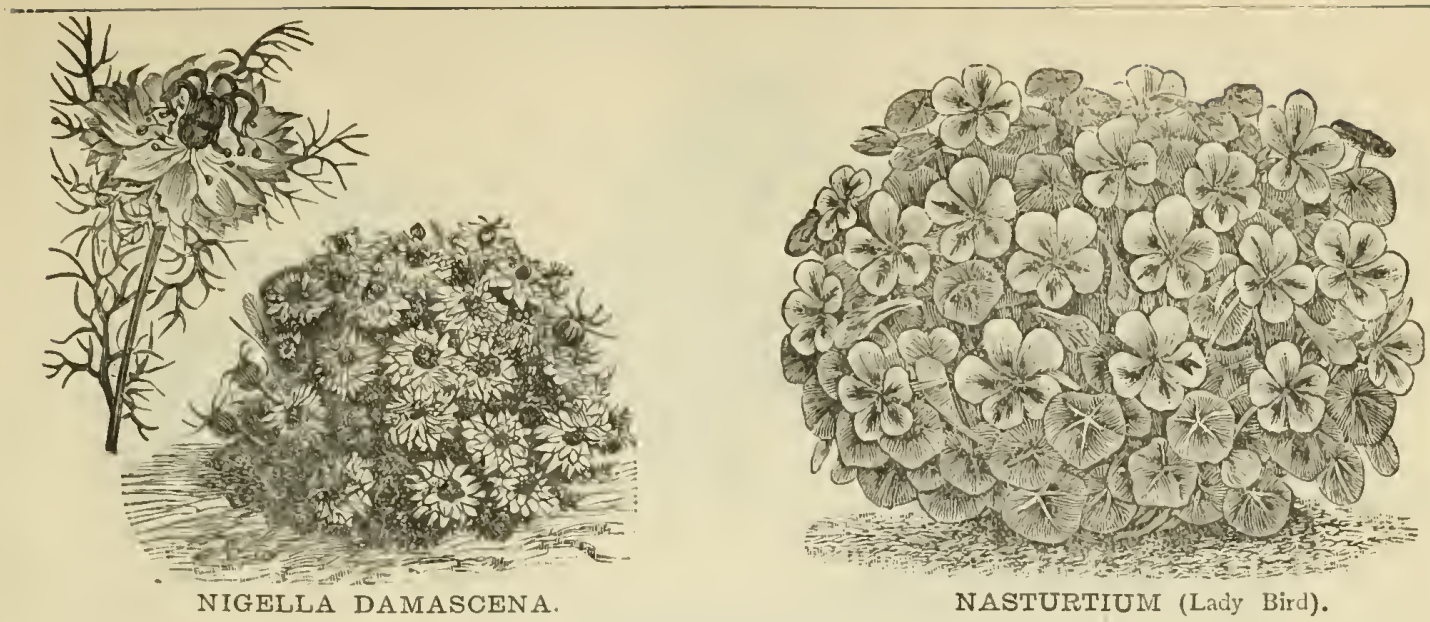

NAME.

DESCRIPTION.

\begin{tabular}{|c|c|c|}
\hline HAR & H'G'T & PRICE \\
\hline AND & FT. & PER \\
\hline & & \\
\hline
\end{tabular}

NICOTIANA. A family of ormamental foliaged plants of stately habit, one of which is the ubiquitous Tobacco Plant.

Affinis, deliciously scented, large, white tubular flowers, in full beauty morning and evening

“ Decurrens, pure white, very sweet-scented

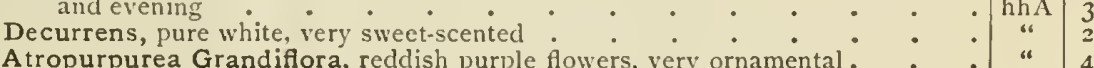

NIEREMBERGIA. Charming little plants, which flower profusely during the whole summer; well adapted for hanging baskets and edgings

Frutescena, lilac, very free-flowering .

Gracilis, light blue, fine for groups

NIGELLA. (Love-in-a-Mist, or Devil-in-the-Bush.) Compact-growing, free-flowering plants, with curious looking, showy flowers and finely-cut foliage.

Mixed

NOLANA. An extreinely beautiful, free-flowering genus of trailing plants, fine for rock-work, hanging-baskets, old stumps, etc.

Mixed Varieties.

NYCTEr NIA. Neat, compact little plants, covered with pretty, sweet-scented, star-shaped flowers, valuable for edgings, rockeries, stumps or small beds.

Capensis, white, with bright yellow centre

“ Selaginoides, pink, yellow centre

OROBUS. Beautiful, showy plants, with pea-shaped flowers.

Mixed, red, white, blue, yellow, etc.

OXALIS. A splendid class of plants with brilliantly-colored flowers and dark foliage, suitable for rock-work or hanging baskets.

Rosea Alba, white, very fine

Delicata, salmon-rose, handsome

Tropæoloides, deep yellow, browı leaves; $\dot{a}$ very interesting variety, excellent for Mixed ribbon-bedding

PAMPAS GRASS. See Ornamental Grasses,

PAPAVER. (Poppy.) A genus of showy, free-tlowering plants, producing a rich effective display in large mixed borders.

Mikado, scarlet and white, petals curled and fringed

Shirley, white, through delicate shades of pink to crimson

Mephisto, scarlet, with black spots

Alpinum, Mixed, a charming species, resembling $P$. Nudicaule, but dwarfer .

Bracteatum, red, marked at the base of each petal with a black spot

Croceum, orange-yellow, the petals being curiously purfled at the edges, very pretty.

Danebrog (Danish Flag), scarlet, with a white spot at the base of each petal; brilliant

Nudicaule (Iceland Poppy), yellow, large and showy; splendid Alpine

Orientale (Oriental Poppy), dark scarlet, with a purple spot at the base of each petal; large and show'; flowers 6 in. diameter

Pavoninum, scarlet, with a black horseshoe-shaped blotch at the base of each petal; very handsome new Poppy .

Double Carnation, Mixed, handsome and well-known species, with double flowers of various colors

Double Ranunculus, Mixed, an ally of the preceding; very fine

Double Pæony, large double Pæony-shaped flowers; very handsome :

Victoria Cross, rich, vermilion-crimson, with a white spot at base of petals :

Umbrosum, immense flowers of a brilliant crimson, with a large black blotch at the base of each petal, very showy .

See Special Offers on third page of cover. ; " 
PAPA VER. Somniferum (Opium), white

PARIS DAISY. See Chrysanthemum Frutescens.

PASSIFLORA. See Climbers,

PASPALUM. See Ornamental Grasses,

PELARGONIUM. See Seeds for Greenhouse,

PENSTEMON. Bell-shaped flowers borne in racemes or spikes. Splendid bedding plants. Very choice mixed, saved from a collection of the finest named sorts

PENNISETUM. See Ornamental Grasses,

PERILLA. Ornamental-foliaged plants for flower-garden decoration.

Nankinensis, leaves deep mulberry or purplish black

66$$
\text { " }
$$

Atropurpurea Foliis Laciniatis, the toothed

PERIWINKLE. See Seeds for Greenhouses,

PETUNIA. A profuse-flowering and easily cultivated favorite; effective and beautiful in beds.

Nyctaginiflora, white, fragrant

Fine Mixed, splendid varieties

Extra Mixed, choice, all colors

Belle Etoile, mixed, large-flowered strain of striped and blotched

Countess of Ellesmere, rose, with white throat, pretty

Dwarf Inimitable, splendid dwarf variety, seldom exceeding six inches in height plants become literally covered with regularly striped flowers, and are exceedingly effective

“ Hybrida Grandiflora, extra choice mixed, choice varieties, large flowers, all colors

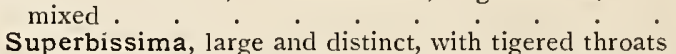

\section{"}

"،

\section{" Superbissin}

Double Striped and blotched, choicest mixed. This strain is saved from carefully fertilized flowers, and will produce a large percentage of doubles, while such plants as are single are marvels of beauty in colors and markings

“

\section{"}

Lilliput Choicest Mixed, compact growth, with spotted, striped, and self-colored double flowers

“

" Fringed Choice Mixed, for richness and delicacy of tint this variety is unsurpassed

PHACELIA. Showy plants with Whitlavia-like flowers; excellent for bees.

Campanularia, bright blue

Tanacetifolia, blue

PHASEOLUS. See Climbers,

PHEASA NT'S-EYE PINK. See Dianthus Plumaris.

PHLOX. These flowers are of extreme beauty, and are greatly admired by all; their long duration in bloom, combined with their unequalled richness of color, renders them of invaluable service in the flower garden.

" Drummondii Fimbriata, fringed petals, many shades of color, with white eye .

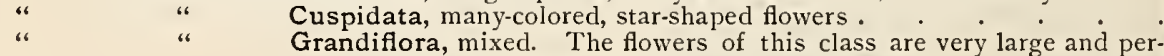
fectly formed; invaluable for bedding purposes.

\section{" Alba, pure white}

“ Oculata, white, with purple eye

“ Atropurpurea, dark purple

$$
\text { “ " } \quad \text { Striata, striped }
$$

" Coccinea, rich, brilliant scarlet

"Isabellina, light yellow

“ Isabellina, light yellow $\quad$ Nana Compacta, Snowball, pure white.

Decussata, saved from the choicest mixed; extra fine.

PINK. See Dianthus.

Nana, dwarf varieties, choice

POA. See Ornamental Grasses,

POLEMONIUM. (Jacob's Ladder.) With large heads of flowers, suitable for borders.

POPPY. See Papaver. Coruleum, blue

PORTULACA. Brilliant and delicate colors; in baskets, small beds, edgings, or rock-work, its large, splendid flowers are extremely effective.

Single Mixed, choice colors

Grandiflora, fl. pl., selected from large double flowers of the most beautiful and brilliant colors, producing a large proportion of double flowers of unsurpassed beauty; mixed colors

POTENTILLA. Handsome plants, exceedingly ornamental in mixed flower borders, lasting a long time in bloom.

Double, choice varieties, mixed .

Single, finest mixed

PRIMULA. (Primrose.) Well-known garden favorites of great beauty, succeeding best in a northern aspect; protect the plants during winter with an inverted sod.

“ Auricula Alpina, various colors d $\quad$ Veris (Polyanthus), early-blooming, dwarf-growing plants, valuable for beds or pot

u

Cowslip

See Special Offers on third page of cover.

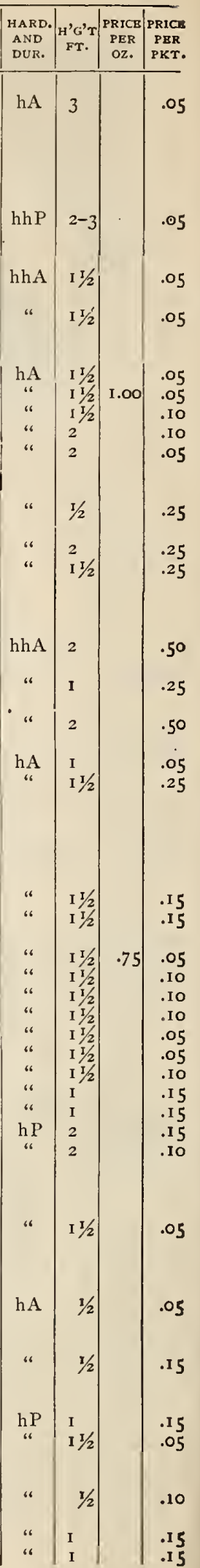




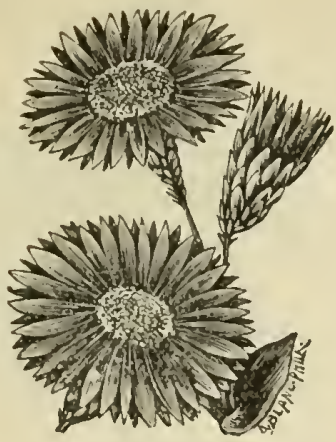

RHODANTHE.

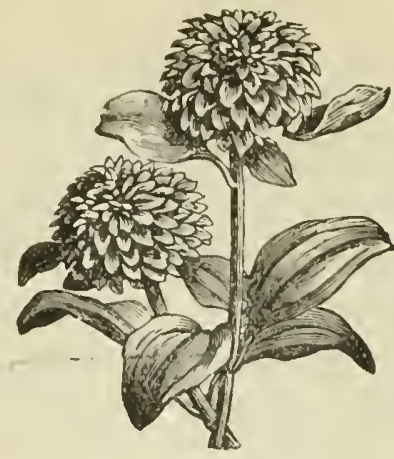

SANVITALIA.

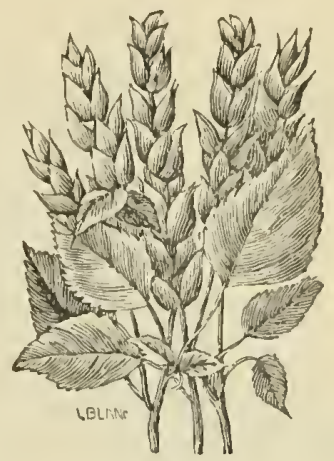

SALVIA.

NAME.

DESCRIPTION.

PRIMULA. Mixed, all colors, beautifully laced or blotched .

Vulgaris, vellow, common English Primrose

Japonica (Japanese), mixed, all colors

Sie also Seeds for Greenhouse,

PRINCE'S FEATHER. See Amaranthus Cruentus.

PRICKLY POPPY. Sie Argemone.

PYRETHRUM. (Feverfew.) Highly ornamental plants, producing a fine effect in mixed flower and shrubbery borders.

A ureum (Golden Feather), golden foliage, invaluable for bedding purposes Selaginoides, a valuable variety for beds or borders

Golden Gem, double white flowers, foliage brightest yellow, fine for beds Hybrid Single, saved from an extra fine collection

Double, a choice strain, large proportion double flowers

QUAKING GRASS. See Ornamental Grasses,

RAGGED ROBIN. See Lychnis.

RANUNCULUS. Brilliant, showy flowers.

Asiaticus Superbissimus, various colors

RED HOT POKER PLANT. See Tritomi.

RESEDA. (Mignonette.) A well-known fragrant favorite, which produces a pleasing contrast to the more showy occupants of the garden.

Golden Queen, distinct, with large spikes of golden yellow blossoms

Miles' Hybrid Spiral, profuse-blooming, very fragrant, splendid for pot culture

Parson's White, distinct, delightfully fragrant variety; highly recommended

New Giant, compact grower, yielding a profusion of immense spikes of fragrant flowers; the best for bee keepers

Giant White Spiral, white, fine spikes, fragrant .

Odorata (Sweet), very fragrant

Machet, well adapted for pot culture, divarf, pyramidal growth, flowers red

The Prize, extra large compact spike, deliciously fragrant

RHODANTHE. See Everlastings,

RICINUS. (Castor Oil Plant.) Magnificent and highıy ormas.ental genus of stately growth, with picturesque foliage.

Borboniensis Arboreus, violet

Corulescens, bluish-green, very fine

Gibsoni, foliage deep red, very attractive

Sanguineus (Obermanii), splendid red fruit in clusters, very ornamental, producing a grand effect.

Philippinensis, gigantic foliage

" Philippinensis, gigantic

ROSE OF HEAVEN. See Agrostemma Cali Rosea.

ROSE CAMPION. Sie Agrostemma Coronaria.

SABBATIA. Very ornamental plants, suitable for borders.

Campestris, rose and yellow

SALPIGLOSSIS. Useful plants for autumn decoration ; curiously pencilled and marbled funnelshaped flowers, effective in beds, borders, edgings, and ribbons.

Choice Mixed, tall

Dwarf Varieties

SALVIA. (Flowering Sage.) Magnificent bedding plants, Joaded with spikes of scarlet flowers.

Coccinea Splendens, scarlet.

Argentea, silvery foliage, white flowers .

Coccinea Hybrida, intense scarlet

Greggi, crimson

Patens, deep blue, superb

Rœmeriana, deep crimson 
SANVITALIA. Dwarf-growing, free-flowering plants, blooming all summer; suitable for beds or rock-work.

Procumbens, fl. pl., flowers double yellow; a profuse bloomer

SAPONARIA. Charming little plants, flowering all the season; splendid for beds or ribbon borders.

Fine Mixed, all colors.

SCABIOSA. (Mourning Bride.) Handsome plants for mixed borders, flowers beautifully variegated; valuable for bouquets.

Candidissima plena, double, white, useful for florists

Atropurpurea, double velvety dark-purple

Nana, fi. pl., double dwarf, brilliant colors, mixer

Finest Mixed, all colors, large-flowered .

SCHIZOPETALON. Delicately fringed flowers, deliciously fragı anı, valuable for bouquets.

SCHYPHANTHUS. See Climbers,

SEDUM. (Stonecrop.) Pretty little plants, growing freely on rock or rustic work; where they flower in great profusion.

Cœruleum, blue Fine Mixed

SENICID. (Jacobæa.) A useful and exceedingly showy class of gay-colored, profuse-blooming plants of easy culture, splendid for rock-work or beds.

Elegans, fi. pl., fine, tall, double, all colors mixed

“ Elegans Nana, fl. pl., dwarf, compact growth

SENSITIVE PLANT. See Mimosa.

SHELL FLOWER. See Molucella.

SILENE. (Catchfly.) Ornamental, free-flowering plants, with bright and beautifully colored flowers, suitable for beds, borders, or ribbon gardening.

Armeria, mixed, all colors

$$
\begin{aligned}
& \text { " Pendula } \dot{\text { " }} \text { ixed } \\
& \text { " " fl.pl. }
\end{aligned}
$$

SNAPDRAGON See Antirrtinum.

SNOW ON THE MOUNTAIN. See Euphorbia.

SOLANUM. Ornamental fruit-bearing plants.

Capsicastrum, orange fruit, excellent for decorative purposes

Wetherill's Hybrids, splendid for table decoration

SPERGULA. An excellent class of plants for edgings, rock-work, or carpet beds.

Pilifera Aurea, golden yellow.

SPHENOGYNE. Free-flowering border plant, suitable for ribbon borders or rock-work.

Speciosa, bright yellow

SPRAGUEA. Amaranthus-like flowers; extremely graceful and beautiful, very effective as an edging, or for rock-work.

Umbellata, white, shaded and spotted purple

SQUIRREL TAIL GRASS. See Ornamental Grasses,

STACHYS. Valuable for edgings or ribbon borders.

Lanata, silver-leaved

STATICE. Very free-flowering; the flowers are valuable for wincer bouquets. Incana Nana, finest mixed, dwarf

STELLARIA. An excellent bedding plant, suitable for edgings or horders.

$$
\text { Graminea Aurea, golden-leaved . }
$$

STEVIA. See Seeds for Greenhouse,

STIPA. See Ornamental Grasses,

STOCKS. See Mathiola.

STONECROP. See Sedum.

SUNFLOWER. See Helianthus.

SWAN RIVER DAISY. See Brachycome.

SWEET ALYSSUM. See Alyssum Maritimum.

SWEET PEA. (Lathyrus.) See Climbers,

SWEET WILLIAM. See Dianthus Barbatus.

SWEET ROCKET. See Hesperis.

TACSONIA. See Seeds for Greenhouse,

TAGETES. (Marigold.) Free-flowering plants, with handsome double flowers of rich and beautiful colors.

Erecta Tall Orange, rich yellow

" "Lemon, sulphur, fine double

" "Orange Quilled, orange, brown, and yellow

"Lemon " sulphur, petals quilled

E1 Dorado, yellow .

Finest Double, mixed, all colors

Patula Tall Double French, fine mixed

Dwarf Double French, finest mixed Striped, extra

Signata Pumila, bright, yellow-striped, brown .

" "Golden Ring, rich orange, of compact growth

Cloth of Gold, golden yellow 


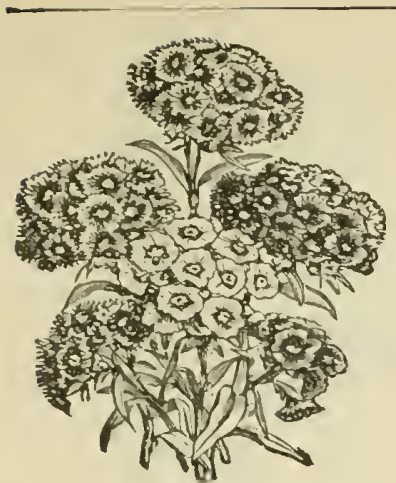

SWEET WILLIAM.
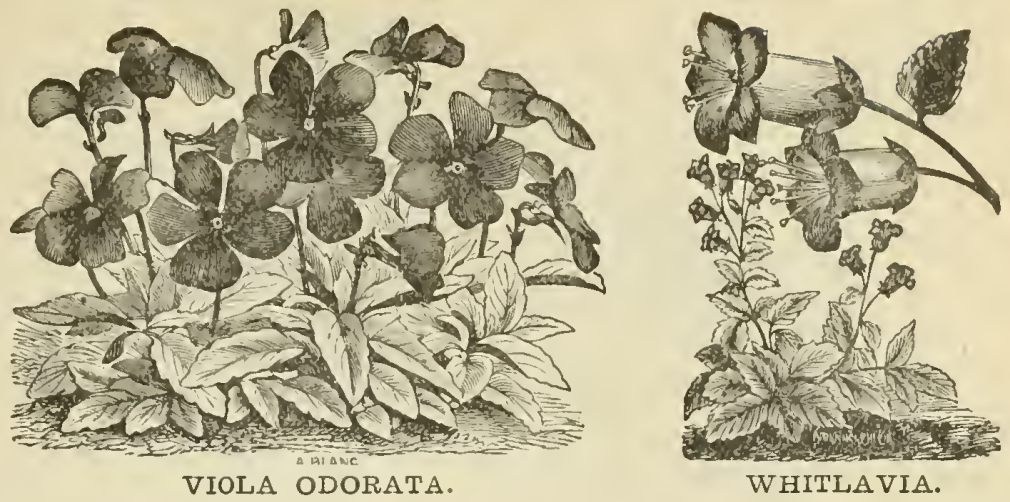

WHITLAVIA.

TASSEL FLOWER. Sec Cacalic.

THUNBERGIA. See Climbers,

TORENIA. Valuable class of plants for vases or hanging baskets.

Fournieri, sky-blue flowers, with three spots of dark blue and bright yellow centre,

THRIFT. See Armeria.

TRICHOL ANA. See Ornamental Grasses,

TRICOSANTHES. See Climbers,

TRIFOLIUM. (Sweet-scented Clover.) Very pretty, and of easy culture.

Sauveolens, white.

TRIPSACUM. See Ornamental Grasses,

TRITOMA. (Red Hot Poker Plant.) The flowers are produced in large spikes of orange-tinted flower tubes; magnificent..

Uvaria Grandiflora (see above description)

TRITONIA. Dwarf-growing, bulbous plants, with tubular shaped flowers.

Aurea, beautiful orange-colored flowers

TROLLIUS. Suitable for beds or mixed borders.

Mixed, all colors

TROPAOLUM NANUM. (Nasturtium Dwarf.) One of the most beautiful and useful plants, invaluable for bedding, massing, or ribboning, of close, compact growth, with rich-colored flowers.

Tom Thumb Beauty, yellow, flushed with vermilion .

Cœrulea Rosea, beautiful peach

Crimson

Crystal Palace Gem, sulphur, spotted mauve

Golden King, golden yellow .

King of Tom Thumbs, intense scarlet, dark bluish-green foliage,

Ruby King, brilliant carmine, very fine

Empress of India, splendid new dark-leaved variety, with crimson flowers

King Theodore, new variety, dark green foliage, flowers almost black

Lady Bird (Bird Flower), orange, red spots.

Pearl, creamy white

Rose, very desirable

Scarlet

Spotted

Yellow

Fine Mixed, from above varieties.

TROP EOLUM MAJUS. See Climbers,

TRUMPET FLOWER. See Datura.

TRUMPET VINE. See Climbers,

UMBILICUS. A genus of interesting plants, valuable for rock-work, edgings, and borders. Sempervivum, blood-red flowers .

UNIOLA. See Ornamental Grasses,

VALERIANA. Showy plants for mixed borders or shrubberies, bearing large, bright flowers. Mixed, all colors

VENIDIUM. Fine for borders, edgings, or rock-work.

Calendulaceum, golden-yellow, daisy-like flowers .

VENUS-LOOKING-GLASS. See Campanula Speculum.

VERBENA. One of the best bedding plants in cultivation, unrivalled in the splendor of its dazzling brilliancy of flower; constant bloomer; if grown from seed, has a sweet fragrance.

Hybrida Auriculafloræ, choice mixed varieties, with white centre .

" Compacta Candidissima, immense trusses of pure white flowers.

Coccinea, scarlet

See Speclal Offers on third page of cover. 
NAME.

DESCRIPTION. \begin{tabular}{c|c|c|c} 
HARD. & H'G'T & PRICE & PRIC \\
AND & FT. & PER & PER \\
LUR. & OZ. & PKT \\
\hline
\end{tabular}

VERBENA. Hybrida Cœrulea, beautiful blue, constant

" " Defiance, beautiful, rich scarlet

“ Italian Striped, mixed

" Coccinea, brilliant scarlet

" Lutea, yellow

“ Choice Mixed

Fine Mixed

Aubletia, reddish purple

Montana, a perfect gem; the plant literally covers $\dot{\text { itself }} \dot{\dot{m}}$ during the summer with

its bright, rose-colored flowers; perfectly hardy

Teucroides Odorata, fine white, fragrant .

Venosa, violet purple; good bedding plant; trailer .

VERONICA. Showy plants for pot culture, rock-work, or the open border.

Perennial, mixed, all colors

VINCA. See Seeds for Greenhouse.

VIOLA. (Violet.) Well-known plants, suitable for edgings, groups, or mixed borders, and much in demand on account of their fragrance and profusion of bloom.

Cornuta Mauve Queen, extra purple

" Magnificent, light blue, very fine

" White Perfection, pure white.

Odorata Semperflorens, blue

Alba, pure white, sweet-scented

The Czar, light violet, very fragrant

" "White Czar, white, fragrant

VIOLA TRICOLOR. (Pansy, Heart's-ease.) Nothing can be more effective, whether grown in beds, ribbons, groups, or interspersed among other plants in the border; admirably adapted for pot culture, or the decoration of the conservatory during the winter and spring months.

" 1 "

“

“

16

" "

"6

" "

"6

“

6

4

" "

" "

" 4

" 6

"6 6

Cassier's Superb, most varied and attractive

Roemer's Giant, unsurpassed for size and variety of color

Breck's International Prize, a special mixture of the very choicest sorts, only prepared by ourselves

English Fancy, large flowers, beautifully blotched, very attractive

English Show. The flowers of this class are one-colored, and embrace many beautiful shades

Azure Blue, very fine

Trimardeau. The flowers are marked with three large blotches or spots, and are of a size hitherto quite unattained in this genus. The flowers are finely formed, and of the richest shades of color

Bronze, reddish-brown flowers

Cliveden, yellow, purple, magpie, and white, mixed ; best for bedding,

Emperor William, brilliant blue, with well-defined purple eye, splendid,

Faust, or King of the Blacks, densest black Pansy known .

Gold Margined, very showy.

Golden Yellow, beautiful

Mahogany-color, peculiar shade

Odier or Five-spotted, a distinctly blotched variety of great beauty

Snow Queen, a charming, delicate, satiny-white, slightly tinged with yellow towards the centre; splendid bouquet variety

Striped or Variegated, very showy

White, appropriate for cemeteries

Mixed, from above varieties

Good Mixed

Havana Brown, new shade

Fawn

Lord Beaconsfield, violet, shading to pure white on upper petals

VIRGINIA CREEPER. See Climbers,

VIRGIN'S BOWER. See Climbers,

VISCARIA. Pretty, profuse-flowering plants, for beds, ribbons, or mixed borders.

Cardinalis Nana, mixed

WAHLENBERGIA. (Bell Flower.) Handsome, showy plants, with bell-shaped flowers.

WAITZIA. See Everlastings,

Grandiflora, mixed

WALL FLOWER. Set Cherranthus,

WIGANDIA. A beautiful ornamental plant, with large leaves richly veined, suitable for lawns.

Caracasana Imperialis.

WIND FLOWER. See Anemone,

WHITLA VIA. Charming plants, producing bell-shaped flowers in profusion.

Alba, pure white

Gloxinoides, tube of corolla pure white, lines of a delicate light blue

XRRANTHEMUM. See Everlastings,

YARROW. See Achillea,

ZEA: See Ornamental Grasses, 


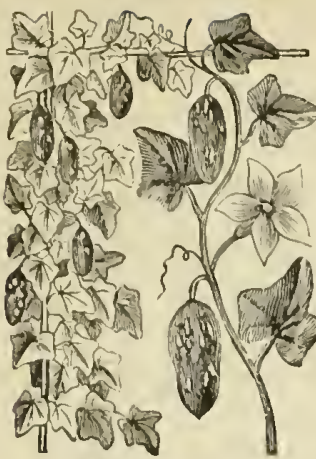

COCCINEA INDICA.

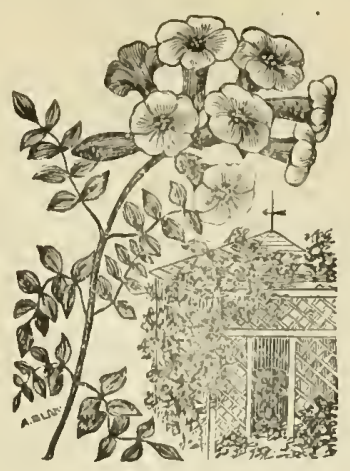

BIGNONIA.

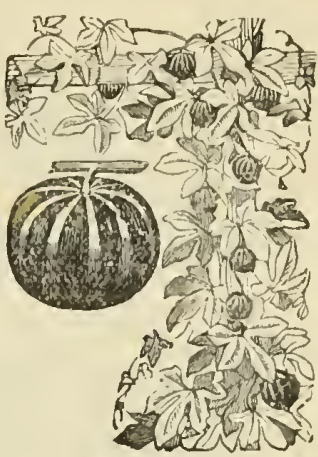

BYRONOPSIS.

NAME.

DESCRIPTION

ZIN NIA. The double Zinnia is one of the novelties of recent years. The flowers are large, beautifully formed, and exceedingly handsome; invaluable for bouquets.

Elegans, fi. pl. Alba, white

" "Coccinea, scarlet

"Mixed, all shades

Grandifora Plenissima, mixed

Dwarf Alba, large flowered, white.

"Lutea, yellow, extra

" Coccinea, scarlet, very fine

"Mixed.

Darwini, fl. pl., pompon, excellent for bouquets

Haageana, fi. pl., deep orange

Tom Thumb

CLIMBERS.

A BOBRA. Rapid-growing climber with glossy, dark green foliage.

Virdiflora, scarlet fruit

ADLUMIA. (Alleghany Vine.) A beautiful perennial climbing plant of graceful habit, with delicate pale-green foliage somewhat resembling the Maiden Hair Fern. Sow in a shady place in spring and transplant very carefully in September; flowers freely all summer; also called "Mountain Fringe."

Cirrhosa, flesh-colored

ALLEGHANY VINE. See Adlumia.

AMPELOPSIS. A class of very beautiful plants, foliage glossy green, changing in autumn to a coppery-red.

Quinquefolia (Virginia Creeper), one of the most valuable climbers for covering walls, porches, or trees

Veitchii (Boston Ivy or Japanese Ivy), clings very readily to stone-work, useful for covering up unsightly objects, used very extensively in the decoration of houses in Boston

(For plants see Nursery Department.)

ARISTOLOCHIA. (Dutchman's Pipe.) Curious climber, with broad foliage, of a brownishpurple, and singular flowers of a brownish-yellow color. It grows from 20 to 30 feet high, and if trained on the piazza, or against a house, the effect is charming. Hardy.

Sipho, yellowish-brown

BALLOON VINE. See Cardiospermum.

BEANS. See Phaseolus.

BIGNONIA. (Trumpet Vine.) Magnificent climber, with brilliant flowers, deserving a first place as an ornamental and effective covering for walls, houses, etc.

Radicans, scarlet .

BOSTON IVY. See Ampelopsis Veitchii.

BYRONOPSIS. A fine climber, bearing green fruit, changing to scarlet and white. Erythrocarpa, see above

CARDIOSPERMUM. (Balloon Vine.) A pretty climber, remarkable for its inflated, mem: branous capsule, from which it gets the name Balloon Vine.

\section{CHINESE LOOFA GOURD}

Halicacabum, white

CLEMATIS. (Virgin's Bower.) An old favorite, much improved of late years.

(For plants, see Nursery Department.)

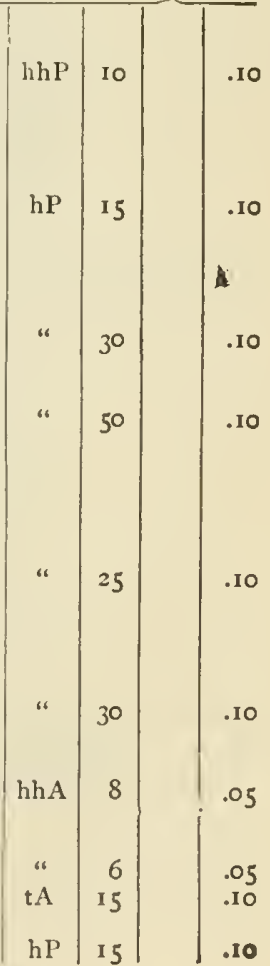

See Special Dffers on third page of cover. 
СОВ $\mathbb{E A}$. A magnificent, rapid growing plant, with beautiful foliage and large, bell-shaped flowers: the seeds should be planted edgewise in moist earth.

Scandens, purple lilac

COCCINEA. Handsome climber, with glossy green foliage. Indica, scarlet

CONVOLVULUS MAJOR. '(Morning Glory.) A free-flowering class of climbers, with brilliant and varied colored flowers, producing a splendid effect when grown on rock-work.

CUCUMIS. Of extremely rapid growth, and bears curious fruits.

" Anguarius, small yellow fruit

Dipsaceus, yellow, teasel-like

Perennis, foliage highly ornamental

CUCURBITA. (Gourds.) Ornamental. A climbing class of rapid growth, producing fruit of various sizes and shapes. Wherever grown, they never fail to excite admiration.

“ Angora, white, spotted, of rapid growth

“ Apple, very ornamental

“ Double Bottle, well-known, and very useful

Gooseberry, very small

Hercules Club, large, club-shaped

Lemon, very showy

Orange, well-known sort

Pear-shaped

Fine Mixed, from a large collection

Argyrosperma, fruit large and finely striped

Leucantha, long, curious fruit

CYCLANTHERA. A climber, bearing oval-shaped fruit.

$$
\text { Pedata. }
$$

CYPRESS VINE. See Ipomcea Quamoclit.

DOLICHOS. (Hyacinth Bean.) A beautiful class of quick-growing ornamental climbers, producing an abundance of clustered spikes of flowers, followed by exceedingly ornamental seed-pods.

\section{“ Lablab, purple.}

Alba, white

DUTCHMAN'S PIPE. See Aristolochia.

HYACINTH BEAN. See Dolichos.

IPOMCEA. This class ranks pre-eminent for delicate and intrinsic beauty; the brilliant and varied hues of its many species and varieties are exceedingly beautiful.

Bona Nox (Evening Glory), satin-rose, large, fragrant blossoms, which expand in the evening

Noctiflora (Moon Flower):

Coccinea (Star Ipomæa), scarlet, small flowers in great profusion

Hederacea Superba, ivy-like foliage, very showy, mixed colors

Limbata Elegantissima, rich, bluish-purple centre, in the form of a star, with broad, pure white margin

Quamoclit (Cypress Vine), flowers and foliage both very beautiful; half hardy, mixed colors

Scarlet, White, each color .

LATHYRUS. (Sweet Peas.) Fragrant and profuse climbers, continuing in blossom throughout the season; valuable for bouquets.

Black Purple Striped, extra .

Butterfly, white ground, delicately laced with blue

Crown Princess, delicate blush, very fine

Invincible Scarlet, rich scarlet, extra

Joanna Theresa, light blue and purple, extra

Red Striped, beautifully striped

Painted Lady, rose and white; excellent

Captain Sharkey, dark red; beautiful .

Violet Queen, charming, ranging from deep mauve to light violet

White, snow-white .

Fine Mixed, all colors and shades

Choice Mixed, a special mixture of our own

Latifolius Alba, white and rubra, red colors separate

$$
\text { Mixed, colors mixed }
$$

LOASA. A beautiful climber; very floriferous.

Hispida, golden yellow, extra

Tricolor, orange, red and green

LOPHOSPERM UM. Beautiful vine with large, trumpet-shaped flowers; excellent for vases or baskets.

Scandens, rosy-purple
MAURANDYA. Graceful and free-blooming climber with bell-shaped flowers, in shape resemblirg the Digitalis.

Barclayana, purple

Emeryana Rosea, dark rose

Fine Mixed, all shades 
MOMORDICA. Very ornamental, fruit of a golden-yellow color, warted; when ripe, opens, disclosing its seeds and brilliant interior.

Balsaminia (Balsam Apple).

Charantia (Balsam Pear)

MORNING GLORY. See Convolvulus Major

NASTURTIUM. See Tropacolum.

PASSIFLCRA. (Passion Flower.) The Howers are interesting and beautiful.

(Passion Flower.)
Cœrulea, sky-blue

" Gracilis, white

Princeps Coccinea, magnificent

PHASEOLUS MULTIFLORUS. (Climbing Beans), of rapid growth, ornamental.
-6 "6 Scarlet Runner, producing brilliant scarlet flowers

PASSION FLOWER. See Passiflora. White Dutch, the flower and bean both whit

SCHYPHANTHUS. Very pretty climber.

Elegans, yellow .

TRICOSANTHES. (Snake Cucumber.) A curious class of plants with serpent-like fruit.

Colubrina, serpent gourd, very ornamental

THUNBERGIA. A genus of slender and rapid-growing climbers, with extremely pretty and much admired flowers, which are freely produced.

Alata, orange, rich brown eye

Alba, white, with dark eye

TROPAOLUM. (Climbing Nasturtium.) Elegant-growing, profuse-flowering, and éasily cultivated climbers, with great richness and brilliancy of color; for covering trellises, verandas and bowers, they are unsurpassed.

Majus Atropurpureum, dark crimson

" Coccineum, bright scarlet

Luteum, yellow

Regelianum, purple-violet

Coerulea Roseum, deep rose

Dunnett's Orange

Edward Otto, brown-lilac, fine

Heinnemanni, chocolate, choice.

Hemisphericum, orange, handsome

King Theodore.

Scheurvianum, straw-color, spotted

" " Coccinum, scarlet, striped

" Fine Mixed, all colors and shades

Lobbianum, Crown Prince, deep red

" Giant of Battles, brilliant carmine, fine

Lucifer, very dark crimson

Napoleon III, yellow, striped with rosy-scarlet

Roi des Noirs, almost black

Spitfire, brilliant scarlet, excellent

Mixed, all colors .

Peregrinum (Canary Bird Flower), yellow, highly ornamental and deservedly a favorite

TRUMPET VINE. See Bignonia,

VIRGINIA CREEPER. See Ampelopsis Quinquefolia,

VIRGIN'S BOWER. See Clematis,

\section{GREENHOUSE.}

ABUTILON. (Chinese Bell Flower.) Popular genus, with bell-shaped, drooping flowers, which are borne in profusion nearly the entire year.

Finest Mixed, flowers vary from pure white and yellow to deep orange and crimson, streaked with yellow

BEGONIA. (Tuberous-rooted.) Tuberous-rooted Begonias are resplendent with their beautiful flowers during the whole summer.

Robusta Perfecta

Tuberous-rooted Single

BELL FLOWER. See Abutilon.

Double.

CALCEOLARIA. Valuable class, remarkable for their large, beautifully-spotted blossoms.

Hybrida Grandiflora, Self's Mixed, robust and free-flowering; large flowers, and great variety of color

Tigers Mixed, extra strain of the most brilliantly. colored and beautifully marked flowers.

Striped Mixed, produces is to 20 per cent of

CHINESE BELL FLOWER. See Abutilon. fowers beautifully striped or marked

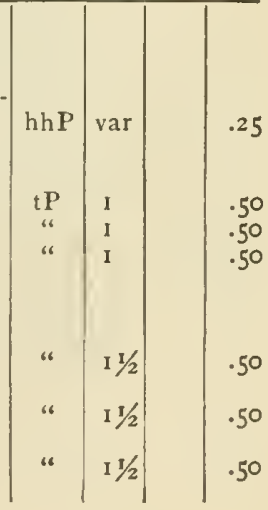

See Special Ofters on third page of cover. 
CHRYSANTHEMUM. A most valuable class of plants for growing in pots.

Indicum Grandiforum, double, choice, mixed, all colors

Japanese, extra choice, mixed

Pompon, double, small flowering .

Double Good Mixed, above varieties

CYCLAMEN. Bulbous-rooted plants, producing exceedingly handsome flowers.

\section{Persicum Album, pure white}

Rubrum, rich red
" Mixed (choice strain), all colors
"

Mixed, all colors and shades.

CINERARIA. A very ornamental and much-admired genus; very free-flowering and brilliant.

Hybrida, New Dwarf, plants globular in shape, and blossom profusely

\section{$"$}

" Flore Pleno, the colors run through all the shades peculiar to $C$

Choicest Mixed, from the best named varieties; extra choice

CIGAR PLANT. See Cuphea.

CLIANTHUS. Magnificent clusters of drooping flowers, somewhat resembling a parrot's beak.

Dampieri, bright scarlet blossoms

COLEUS. A well-known and ornamental foliage plant.

\section{“ Fine Mixed.}

New Large-Leaved

CUPHEA. (Cigar Plant.) A choice plant for conservatory or parlor.

Platycentra, scarlet, white, and purple, mixed

ECCREMOCARPUS. (Calampelis.) A vigorous climber, producing flowers in the greatest profusion.

Scaber, foliage small, flowers orange

FUCHSIA. Well-known plants of easy culture. Our seed saved from a fine collection.

Finest Mixed, from choice named varieties

GERANIUM. See Pelargonium.

GLOXINIA. A superb genus of plants, beautiful flowers of the richest and most brilliant colors. Choicest Mixed, from the finest erect and drooping varieties.

HELIOTROPE. See Heliotropium.

HELIOTROPIÚM. (Heliotrope.)

Finest Mixed

HUMEA. A remarkably handsome plant, invaluable for decorative purposes.

Elegans, red

LANTANA. A remarkably handsome, free-flowering plant with brilliantly colored flowers. Finest Varieties Mixed

MYRSIPHYLLUM. (Smilax.) A beautiful climber; nothing can excel this plant in beauty of foliage and orange fragrance of flower.

Asparagoides

PELARGONIUM. (Geranium.) Well-known favorites, indispensable for in-door and outdoor decoration. The seed we offor has been saved from first-class varieties.

Apple-Scented, a well-known favorite variety

Fancy, choice greenhouse varieties

Large-Flowered, from prize varieties .

Scarlet, fine mixed

Zonale, choicest hybridized variegated varieties:

PERIWINKLE. See Vinca.

PRIM ROSE. See Primula.

PRIMULA. (Primrose.) A charming, profuse-flowering plant, indispensable for winter and spring decoration in the conservatory or sitting.room.

Obconica, white, changing to lilac

Sinensis (Chinese), an extra selected strain

Fimbriata, very choice mixed

Fern-Leaved, beautifully fringed flowers, with finely cut foliage

Flore Pleno, fine double-fringed flowers

STEVIA. A useful plant, either for pot culture or borders; elegant in bouquets.

Lindleyana, reddish white

Purpurea, purple

Eupatoria, white

TACSONIA. Magnificent climbers, with flowers suspended on thread-like filaments.

Van Volxemi, scarlet flowers, with fruit of a sub-acid taste

VINCA. (Periwinkle.) A class of very pretty, free-flowering plants, with shining green toliage. Alba, white, red eye .

Pura, pure white

Rosea, rose

Mixed, all colors

See Special Offers on taird page of cover. 


\section{EVERLASTINGS.}

NAME.

DESCRIPTION.

\begin{tabular}{|c|c|c|c|c|}
\hline HARD. & H'G'T & PRICE & PRICE \\
AND & PER & PER \\
\hline
\end{tabular} \begin{tabular}{|c|c|c|c|} 
AND & FT. & PER & PER \\
DUR. & OZ. & PKT. \\
\hline
\end{tabular}

ACROCLINIUM. Handsome plants, with daisy-like flowers, valuable for winter bouquets. " Roseum, beautiful rose

Alba, fl. pl., good double, fine rose .

" A. pl., (new) double, white

“

Mixed, all colors

AMMOBIUM. Flowers pure white; gather before fully expanded to preserve for winter.

" Alatum, white

ELICH RISUM. See Itelichrysum.

GLOBE AMARANTH. See Gomphrena.

GOMPHRENA. (Globe Amaranth.) Showy globular flowers, which retain their beauty for years.

Aurea Superba, orange

Globosa Alba, pure white .

“ Rosea, rose

“ Nana Compacta, dwarf, compact growth, rich, deep violet-red .

Mixed, all shades and colors

HELIPTERUM. Small foliage, large clusters of bright golden and pure white star-like flowers.

Sanfordii, golden Mixed.

HELICHRYSUM. Exceedingly handsome for winter bouquets.

Bracteatum, single yellow

Lanatum, silvery foliage, nowers light yellow

Fireball, crimson

Monstrosum Album, fi. pl., double white.

Luteum, ff. pl., doubie yellow

Purpureum, A. pl., double purple

Roseum, f. pl., fine, double rose

Double Mixed, all colors

Nanum F'lore Pleno, dwarf, splendid mixed

Minimum, fl. pl., mixed, small flower, double

RHODANTHE. A well-known Everlasting; fine for bedding or ribboning.

Maculata, rosy purple, with crimson centre Alba, white, very showy

Manglesii, bright rose

WAITZIA. Flowers in clusters; pick early, before centre becomes discolored

Grandiflora, deep yellow

XERANTHEMUM. A showy class of Everlastings; excellent for bouquets.

Album, fl. pl., double white.

Purpureum, fl. pl., double purple

Double Pompon, white

purple

\section{ORNAMENTAL GRASSES.}

ABYSSINIAN GRASS. See Poa Amabilis.

AGROSTIS. Nebulosa, very graceful ; indispensable for bouquets

ANDROPOGON. Fine sub-tropical plants.

Argenteus, very ornamental
Schimperi, very stately.

ANIMATED OATS. See Avena Sterilis.

ANTHOXANTHUM. Gracile, clegant

IRUNDO. Conspicua (New Zealand Pampas Grass)

Donax Folio Variegatis, striped foliage

AVENA. Sterilis (Animated Oats).

BRIZA. The well-known Quaking Grass; spreading.

“ Gracilis, small

Maxima, large

BRIZOPYRUM. Siculum, splendid for edgings and bouq' lets

BROMUS. Brizæformis, fine Briza-like; excellent for bouquets .

EERATOCHLOA. Pendula, graceful

¿HLORIS. Elegans, very effective in bouquets and borders; slender and elegant Barbata, bearded ; very neat

CHLOROPSIS. Blanchardiana, bottle-brush-like flowers of a bright rose color

CHRYSURUS. Aurens, golden-spiked; a very desirable sort

COIX. Lachryma (Job's Tears)

YLEUSINE. Oligostachya, three horns, very pretty

IRAGROSTIS. Elegans (Love Grass), beautiful for borders, and indispensable for bouquets

cRIANTHUS. Ravennæ, a noble grass, resembling the Pampas

EULALIA. Japonica, magnificent Japanese grass, attaining a height of 6 to 7 feet.

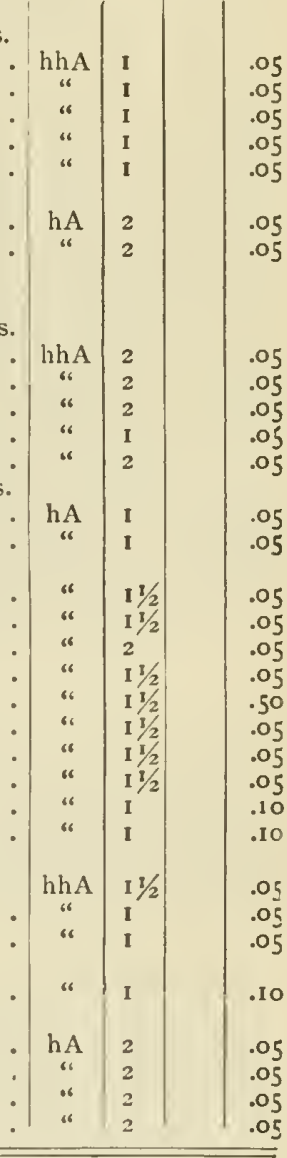


FEATHER GRASS. Sec Stipa Pennata.

FESTUCA. Pectinella, dwarf, compact growing grasses for bouquets and edgings Viridis, fine edging plant

GYNERIUM. Argenteum (Pampas Grass), a well-known variety

Jubatum, splendid species, with beautiful spikes of silvery red flowers

HARE'S TAIL. See Lagurus.

HORDEUM. Jubatum (Squirrel-tail Grass) •

ISOLEPIS. Gracilis, fine for Jardinets

JOB'S TEARS. See Coix.

LAGURUS. Ovatus (Hare's Tail), elegant; a well-known sort

NEW ZEALAND PAMPAS GRASS. See Arundo Conspicua.

ORNAMENTAL MAIZE. See Zea Japonica.

PAMPAS GRASS. See Gynerium Argenteum.

PASPALUM. Elegans, pretty for borders or shrubberies

PENSISETUM. Longistylum, the most distinct and beautiful of ornamental grasses POA. Amabilis (Abyssinian Grass) .

QUAKING GRASS. See Briza.

SQUIRREL-TAIL GRASS. See Hordeum.

STIPA. Elegantissima, extremely elegant; the best of its class.

Pennata (Feather Grass)

TRICHOL ENA. Rosea, very pretty

TRIPSACUM. Dactyloides, pretty for edgings

UNIOLA. Latifolia, beautiful for bouquets

ZEA. Japonica Variegata (Ornamental Maize), prized for its beautiful, variegated foliage

“ Finest Mixed, all varieties

\section{WILD GARDEN SEEDS.}

Any one who has cultivated flowers in neatly laid out beds or carefully planned ribbon borders is aware of the amount of labor and constant attention necessary to produce the desired effect. To those who cannot give this care, we affer "Wild Garden Seeds," a mixture of over one hundred varieties of hardy flower-seeds. No one who has not seen such a bed can form an idea of its possibilities, the different seasons of bloom insuring something new almost every day. Halfounce packets, 25 cents.

\section{COLLECTIONS OF FLOWER SEEDS.}

Collection "A," price 25 cents, contains one packet each of Mignonette, sweet; Alyssum, sweet, white; Sweet Peas, fine mixed; Phlox Drummondi, fine mixed; Portulaca, fine mixed; Chinese Pink, fine mixed.

Collection "B," price 50 cents, contains the varieties in Collection " A," with the following in addition: Nasturtium, Tom Thumb, fine mixed; Candytuft, finest mixed; Aster, German, fine mixed; Pansy, finest mixed; Eschscholtzia, fine mixed; Morning Glory, fine mixed.

COLlect ION " C," price 75 cents, contains the varieties in Collections "A " and " $\mathrm{B}$," with the following in addition: Coreopsis, fine mixed; Balsam, fine mixed; Zinnia, fine mixed; Mourning Bride, fine mixed; Petunia, finest mixed; Calendula, "Meteor," yellow.

COLlECTION "D," price $\$ 1.00$, contains the varieties in Collections "A," "B" and "C," with the following in addition: Tall Nasturtium, fine mixed; Marigold, French, striped; Larkspur, dwarf Rocket; Poppy, double mixed; Convolvulus, dwarf mixed; Chrysanthemum, fine mixed; Antirrhinum, finest mixed.

\section{IMPORTED COLLECTIONS OF GERMAN FLOWER SEEDS.}

\section{ASTERS.}

Dwarf German, in 6 and 12 varieties Chrysanthemum, in 6 and $12 \mathrm{v}$. Victoria, in 6 varieties

Cocardeau or Crown, in 4 vars. . Quilled German, in 6, 12 , and 18 vars. .35 Pæony Perfection, in 6 varieties Victoria, in 6,12 , and 24 varieties . $.60^{\circ}$ Imbricated Pompon, in 6 and 12 vars.

Truffaut's Imp'd Pæony Perfection, in 6,12 , and 18 varieties

Cocardeau or Crown, in 6 varieties $\cdot 40^{\circ}$ Tall Chrysanthemum, in 6 varieties Washington, in 6 varieties

\section{MISCELLANEOUS.}

Grasses (Ornamental), in 12 and 25 vars. $\$ 0.65$ and $\$ 1.00$ Hollyhock (Chater's), in 6 and 12 vars.
Per Coll.

$\$ 0.40$ and $\$ 0.75$

$.50 " .90$

.60 « $\quad .35$

.40

1.00 " 1.50

.50 " .90

.75 " 1.10

.60 .75 Tropæolum Tom Thumb (Divarf Nas Viola Tricolor Maxima (Pansy or Heartsease).

Poppy, Double Carnation Flowered, in Io varieties

Petunia, Hybrida Grandiflora.

Single Choice, in 6 and 12 varieties Double, " in 6 and 12 varieties

Phlox Drummondi Grandiflora, in 6 and $I 2$ varieties

Portulaca, Choicest Single, in 8 vars. .

Stock, Large Flowering German, 6 vars. : week, in 8 and $\mathrm{I} 2$ varieties

Tropæolum Lobbianum, in 12 varieties.

Tropeolum Majus (Tall Nasturtium), in I 2 varieties.

Best German, in 6, I 2, and 18 vars. .40 .70 " 1.25 Zinnia Elegans, in 6 varieties
Per Coll.

$\$ .65$ and 1.25 1.00 " 1.50

$.60 " 1.00$ .50 .50

.65 " 1.00 .75 .50 .50 .75 “ 1.20 .55

See Special Offers on third page of cover. 


\section{PLANT DEPARTMENT.}

To this important branch of our business we are giving much attention, and are in a position, second to none, to supply Fruit Trees, Shane and Ornamental Trees, Evergreen and Flowering Shrubs, Vines, Herbaceous and Summer Beding Plants, etc., in all desirable varieties and sizes at lowest prices. We shall be glad to advise intending buyers as to selection, and also furnish plans and estimates for laying out and planting ornamental grounds

While we exercise the greatest care to have all Nursery stock pure and reliable, we sell no Trees, Plants, Shrubs, or other Nursery stock with warranty, express or implied, in any respect. If the purchaser does not accept these goods on these terms, they must be returned at once.

\section{SINGLE ROSES.}

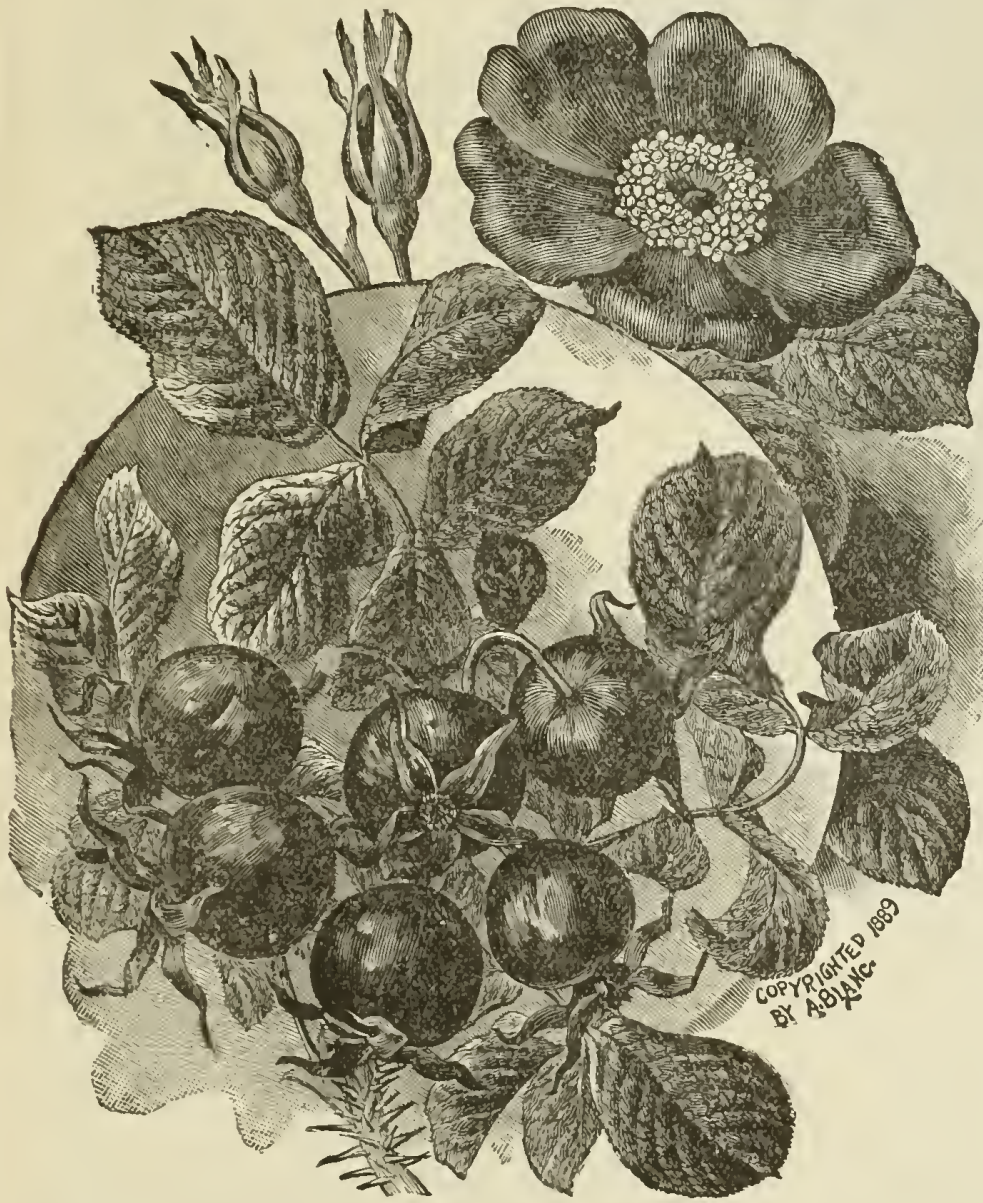

The many articles on SINGLE Roses in the horticultural papers have caused considerable attention to be directed to them. Single Roses are highly decorative in the flower-garden, and so beautiful for vases and bouquets in the cut state, that every garden should possess some of the varieties.

Capucine, Austrian Copper. A graceful, showy, and interesting favorite. The flowers, which are freely produced, are very distinct, being of an exceptionally bright, dazzling orangescarlet, shading to orange at the base of the petals. 50 cents each; $\$ 5.00$ per dozen.

Bracteata. The old Macartney Rose, producing small, deep green leaves and large flowers of pearly whiteness and great substance. 50 cents each; \$4.oo per dozen.

Rosa Rugosa Rubra. Forms large, thick, close bushes of very deep, glossy foliage, which is covered with bright, rosy-crimson flowers, succeeded by large berries of a rich rosy-red color. 50 cents each; $\$ 4.00$ per dozen.

Rosa Rugosa Alba. Same as above, except in color, which is pure white. $50 \mathrm{cts}$. each ; \$4.00 per dozen.

Rosa Rugosa Rubra, Standard. IVe offer a few plants of this variety, with a straight trunk 3 feet high, and carrying a round top, which makes a great show during the summer; beautiful as single specimens on the lawn. \$3.00 each.

Rosa Rugosa Alba Standard. Same as preceding variety except in color, which is pure white. $\$ 3.00$ each.

Rosa Blanda. A handsome native sort with light-colored flowers and few thorns. 25 cts. each, $\$ 3.00$ per dozen.

Carolina. Wild s'wamp rose. Flowers very bright. $=5 \mathrm{c}$. each ; $\$ 2$. per doz.

ROSE, JAPANESE. Wachurianna. A trailing species of very rapid growth, making a closely matted bed of very dark green foliage. The leaves are quite small, nearly round, smooth, serrate, shining and nearly evergreen. The flowers are produced in greatest profusion in July, after the June roses are past, and more sparingly throughout the season. They are single, pure white, with yellow stamens, fully two inches across, with the strong and sweet fragrance of the Banksia Rose. It is an invaluable variety for beds, banks, rockeries and for cemetery use, not only when covered with its exquisite flowers, but also for its rich. carpet effect up to the very last of the season. It will be wanted by every one when known. Two year dormant plants, 75 cents. One year pot plants, 25 to 50 cents.

\section{TEA ROSES.}

The Teas are tender, and require careful protection. They should not be planted out in spring until all danger of frost is past. For parlor or conservatory culture they are unequalled.

Bon Silene. Rosy-Carmine, shaded, free flowering, Mad. Hoste. Yellowish-white, centre deeper yellow; fragrant.

Catherine Mermet. Bright silvery pink, fragrant. Cornelia Cook. Pale yellowish-white, large and full. Madam de Waterville. Salmon-white petals edged with bright rose. Very free lowering.

Madam Hardy, Pine white, fine substance, full. good form, very free blooming.

Marie Van Houtte. White, tinged with yellow; large. Niphetos. Pale yellowish white, large buds.

Perle des Jardins. Straw color, large and full.

Safrano. Saffron and apricot, very beautiful.

Waban. A sport of Catherine Ilermet, which it resembles in every way except color; rich, clear pink.

Price, small plants, 25c. each, \$2.50 per dozen; large plants, 50c. each, \$4.00 per dozen.

See Special Offers on third page of cover. 


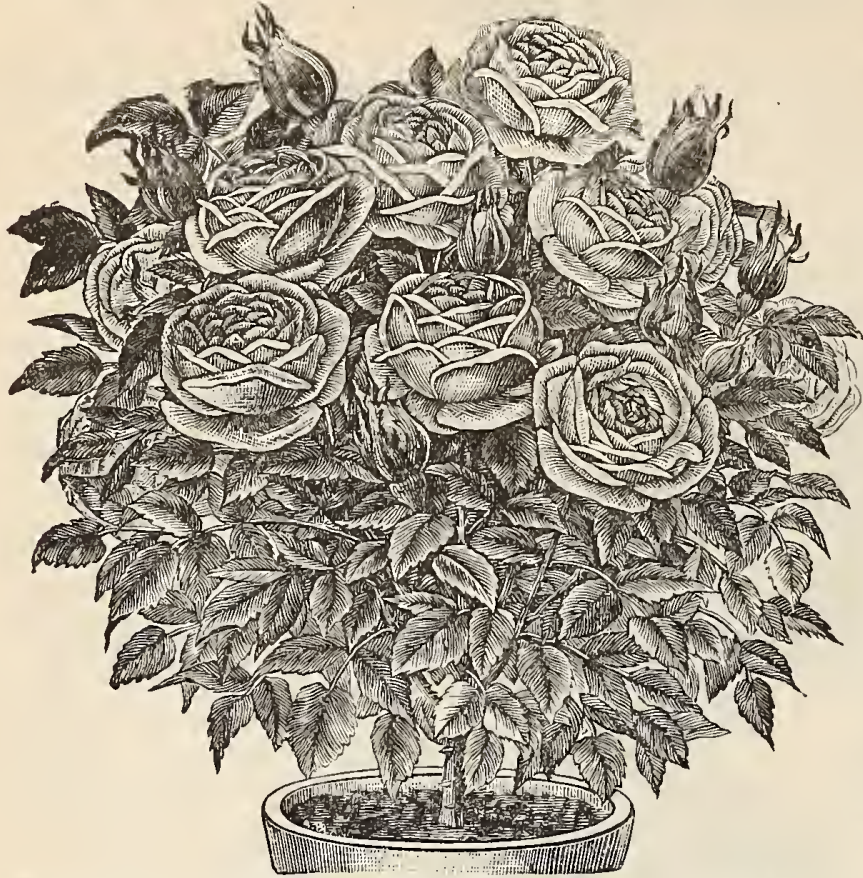

The following statement was embraced in our remarks on Roses in our catalogue of last year: "There exists among growers and lovers of the Rose anvthing but a feeling of confidence towards those from whom the plants are usually procured in America, for the reason that death and disappointment are oftener the results of a carefully planned purchase than the gratifying rewarc's hoped for. Failure may be due to a number of causes, but we think the primary ones are that ordinarily importers consider cost more than quality, and are careless in keeping varieties apart and protected from the weather.

Our experience has been of such a nature that we deemed it best to import direct. We have, therefore, made arrangements with a leading grower in Britain for a supply of his finest plants, of the kind best suited to our climates. The first consignment was received the middle of December last, and the evident care taken in naming and packing, together with the appearance of them, convince us they will prove satisfactory and be a pleasing surprise to our customers." We have now much satisfaction in saying that the success we hoped for in this departure has been fully realized both to ourselves and patrons, and we feel assured of liberal encouragement this season: the plants are exceedingly fine,having good fibrous roots and strong, well-ripened heads; they will flower well this summer if planted early. We guarantee that every rose will be true to name.

PLANTING. If possible select a position sheltered from high winds but open to the sunshine. If the soil is not naturally suitable it must be improved - if light, by the addition of rich loam and decomposed cow or stable manure, well worked in; where stiff and heavy, good drainage and rough stable manure are the essentials.

When planting, carefully prune all dead or bruised roots or branches, spread the root fibres as much as possible, and set deep enough to cover the junction of the bud and stock, thereby preventing suckers and enabling the rose to make roots.

During the growing season frequent waterings with liquid manure is an advantage. It is easily made by mixing cow manure with water in an old tub or barrel.

In the following list of one hundred varieties we have aimed at selecting those that combine, in the fullest manner, the five requirements of a perfect rose, namely: beauty of color; beauty of form ; fragrance ; profusion and continuity of bloom; and vigor of growth. To aid our customers in making selection, who cannot give space to a hundred kinds, we have indicated what we consider the best ffty by prefixing a star*; to the best truenty-five two stars **; to the best twelve three stars ****; to the best six four stars ****.

\$*****Alfred Colomb, bright fiery red, large, full, and globular, very effective.

****Alphonse Soupert, bright pink, form of La Reine, very large.

**Admiral Seymour, deep velvety purplish red, of good form, large.

* Abel Carriere, rich purplish crimson, reverse of petals dark violet, large, full, fine shape.

**Alfred K. Williams, fine carmine red; full, of fine form.

* Anna de Diesbach, beautiful deep rose, very large, cupped, and showy; distinct.

***Baness Rothschild, palest flesh, most chaste and beautiful, large, full, and fine form; one of the very best roses.

**Baron de Bonstetten, bright crimson, very large and finely formed.

k*Baronne de Maynard, pure white, medium size, full, fine form.

* Baronne Prevost, rose color, immensely large.

Baron Adolphe de Rothschild, bright red, large, full, splendid foliage.

Beauty of Waltham, light crimson, large, full, fine form.

Brightness of Cheshunt, peculiarly vivid brick red, approaching scarlet, large open imbricated form; very fine autumnal bloomer.

*** Charles Lefebvre, fine brilliant velvety crimson, large, cupped, and well formed.

*Comte de Serenye, light rosy-peach, perfectly built, round globular form.

Captain Christy, light salmon-flesh, quite a distinct shade of color, fine well-built form, large and free.

Comtesse de Oxford, bright carmine-red, very large, fine form, foliage handsome.
Countess of Rosebery, brilliant carmine-rose, large, full, of fine cupped form, a strong and hardy kind.

***** Duke of Edinburgh, fine vermilion, large, full, and good shape.

****Dr. Andry, bright reddish crimson, large, free, excellent.

*Duchess of Bedford, dazzling light scarlet-crimson, large, full, and of perfect shape.

* Duke of Teck, bright crimson-scarlet, clear, distinct, in its vividness of color beyond anything yet raised.

Duc de Rohan, bright red, very large and full.

Duchesse de Vallombrosa, blush centre, pale satin rose, delicate sweet scent.

Duc de Wellington, dark crimson, large and full.

Dupuy Jamain, very bright cerise, large, full, and fine form; blooms freely.

Duchesse de Morny, splendid clear light rose, large, full, and beautifully cupped.

****tienne Levet, light carmine-red, beautiful globular form.

Exposition de Brie, bright scarlet, large, full, fine form.

* Edward Morren, glossy pink, in the way of Jules Mar. gottin, but of a fresher and more delicate color.

Eclair, bright fiery red, large and full, form of Charles Lefebre.

Elie Morel, rosv lilac, very large, full, and perfect form.

Empress of India, dark brownish crimson, very double.

**Fisher Holmes, crimson, beautifully shaded with violet.

**Francois Michelon, beautiful silvery rose, large, fine petaled, deep form.

* Ferdinand de Lesseps, crimson, beautifully shaded with violet; fine.

*General Jacqueminot. brilliant scarlet-crimson, large, and magnificent. 
Gloire Lyonnaise, flowers chrome yellow, petals edged white, large, full, and finely formed.

*Henrich Schultheis, delicate pinkish rose; very large, very full, of perfect form, very sweet-scented.

Harrison Weir, beautiful rich velvety crimson, enlivened with scarlet; large, full, excuisitely formed.

Horace Vernet, scarlet crimson; large, full, double; a lovely rose.

** Jean Liabaud, velvety crimson, reflexed carmine, and shaded with black; flower very large, full, very fine form.

*John Hopper, fine brilliant rosy crimson, large, full, good form, abundant bloomer.

* John Stuart Mill, bright clear rer, large, full and beautiful form, shell-like petal of great substance.

Jules Margottin, glossy pink, large and superb.

***Louis Van Houtte, reddish scarlet and amaranth, shaded with bluish purple, very large and full.

** La France, bright lilac rose, centre silvery white, petals large, fine form, large and full, extra fine.

Leon Renault, bright light crimson; an enormous flower, and a bold showy garden rose.

La Reine, rose, tinged with lilac, large and full.

La Rosiere, velvety crimson.

Lyonnaise, pink, very bright, a first-rate rose.

Lord Macaulay, bright velvety crimson, large, full, and beautiful form.

****Madam Gabriel Luizet, fine satin rose, very large and full.

**Madam Vidot, transparent flesh, most beautifully formed, flowers medium size.

* Madame Montet, beautiful soft pink; flower large.

Madame Louis Leveque, deep rosy carmine, large, very double, globular form.

Madame Nachury, light silvery rose, deep cupped form, a very distinct rose.

Madame Lelievre Delaplace, bright crimson; very large and full; growth vigorous.

Madame Ducher, fine cherry rose, petals bordered with reddish purple, very large, full, well formed.

Madame Victor Verdier, beautiful cherry rose, large and full, form exquisitely cupped.

Madame Charles Crapelet, light crimson, large and full, splendid form; extra good.

Madame Charles Wood, crimson, shaded with purple, large, of great substance, flowers abundantly.

Madame Lacharme, shaded white, the centre blush, of a beautiful wax-like appearance, of exquisite form.

Madame de Cambacere, rosy crimson, large and full.

Madame Sophie Fropot, soft rosy pink; very delicate, large, full, globular.

** Mdlle. Eugenie Verdier, bright flesh-colored rose, the reverse of the petals silvery white, very large and full, fine form and habit.

* Mdlle. Annie Wood, vivid crimson, very large, and one of the most perfect form.

*Mdlle. Marie Rady, red, bordered with white, very large and full.

Mdlle. Marie Verdier, brilliant red, large and full, free-flowering.

***Marguerite de Roman, flesh-white, centre rosy pink, fine.

Prices : Large plants, 50 cents each; $\$ 4.00$ per dozen; $\$ 35.00$ per 100

Special prices for larger quantities upon application.

Please bear in mind, the roses we offer are vastly superior to those procured from American nurseries.

\section{CLIMBING ROSES.}

Blairii, a new variety that is unsurpassed as a climber; color, rosy-blush; very large and delightfully fragrant flowers; borre in profusion all summer; perfectly hardy.

Climbing Victor Verdier, a perpetual blooming, hardy, climbing rose; color, beautiful, deep carmine; large and well-formed.

Gloire de Dijon, buft, orange centre; splendid foliage; tea scented.

Baltimore Belle, pale blush, changing to white; fine.

Queen of the Prairies, bright, rosy red; frequently with white stripe.
Bamann, brilliant light crimson, large, full, veille de Lyon, beautiful pure white, cup-shaped, very large; sometimes measuring more than four inches in diameter. lar form.

Magna Charta, bright pink, suffused with carmine, very large, full, fine. that variety.

Mabel Morrison, pure white, in Autumn, very delicately and faintly flushed with pink. rose.

arquise de Castellane, beautiful bright rose, very large and full, form perfect; blooms freely.

ur Alexis Lepere, bright red, large, full, globular.

Marchioness of Exeter, clear rose, flushed with a light cherry-rose, very large, finely built up form, fragrant.

arguerite Brassac, deep velvety carmine, very large, full, finely formed.

Oxonian, shaded rose, large and full, fine form. Neron, dark rose, fine form, large and full; a Crom Victor Verdier.

Penelope Mayo, carmine, clear, distinct, medium, very full, and a model as to shape.

Perfection de Lyon, rose, reverse of petals lilac, perfecl cupped form

rincess Mary of Cambridge, beautiful bright pale rose, large and full, abundant bloomer. form, fragrant.

Queen of Queens, pink, with blush edges, large, full, of perfect form, grows and flowers freely.

Rosy Morn, delicate peach color, richly shaded, with salmon rose. large and full, very fragrant.

Star of Waltham, deep carmine, large well-built flower, with deep fine petals. edged scarlet; full globular form, beautiful and novel; alone for brilliancy.

Thomas Mills, very brightest crimson, large, particularly showy, fine bold flower.

lrich Brunner, cerise-red, with large petals; flowers large; a seedling from Paul Neron. distinct.

ictor Verdier, beautiful deep carmine, large and well formed.

delicate flesh-color; large and finely shaped. othschild, similar in all respects except color. purplish rose. 


\title{
MOSS ROSES.
}

Crested Moss. Rose, large and full; beautiful. Glory of Mosses. Blush, very large and full.

Laneii. Rosy crimson, tinted purple; large and full.
Little Gem. Crimson, very small, and double; beautifully mossed.

Princess Adelaide. Pale, glossy rose.

Reine Blanche. Pine white, large and full.

\section{Strong plants, Fifty Cents each; $\$ 4.00$ per dozen.}

\section{AUSTRIAN ROSES.}

These are the showiest yellow roses in cultivation; very profuse bloomers, their bright flowers literally covering the bush.

\author{
Harrisoni, fine golden yellow. \\ I Persian Yellow, the deepest yellow.
}

Fifty Cents each; $\$ 4.00$ per dozen.

\section{POLYANTHA, OR FAIRY ROSES.}

These are of low, compact habit, producing sinall, graceful flowers in great abundance. They are perfectly hardy, and will bloom through the hottest and driest months of summer. Excellent for a border in front of a rose-bed, and for vases. The flowers are especially adapted for personal wear. A most exquisite class, rapidly gaining in popular favor, which they richly deserve.

Little Gem, white, slightly tinted with pink.

Mme. Cecile Brunner, salmon rose, buff shaded. Mignonette, blush; very fragrant and free-flowering.

Price, small plants, $35^{\circ}$ cents each; $\$ 3.50$ per dozen; large plants, 50 cents each; $\$ 5.00$ per dozen.
Paquerette, pure white; dwarf and free-flowering.

Perle d'Or, saffron yellow, deeper in centre, edges white: very fine.

\section{SUMMER BEDDING PLANTS, FLOWERING AND FOLIAGE.}

\begin{tabular}{|c|c|c|c|c|}
\hline & & & & \\
\hline A butilon, in variety & & & $\$ I .50$ & $\$ 10.00$ \\
\hline Achyranthes, Collinsii & & & I.00 & 8.00 \\
\hline Achyranthes, Emersoni & . & . & 1.00 & 8.00 \\
\hline Ageratum, best dwarf, blue & & . & 1.00 & 6.00 \\
\hline Alternanthera, dwarf, scarl & & . & .75 & 6.00 \\
\hline Alternanthera, dwarf, yello & & . & .75 & 6.00 \\
\hline Alyssum, double, white & & . & .75 & 6.00 \\
\hline Alyssum, variegated foliage & & - & .75 & 6.00 \\
\hline Asters, pure white & . & . & .50 & 4.00 \\
\hline Asters, assorted colors. & & . & .50 & 4.00 \\
\hline egonias, choice varieties & & & 1.50 & 10.00 \\
\hline Caladium Esculentum, orn & namer & ntal foliage & 2.50 & \\
\hline Cannas, assorted colors, ext & & . . & 1.75 & I 5.00 \\
\hline Cannas, Crozy's choice new & varic & eties & 3.00 & \\
\hline Calendula, deep yellow & & . & .75 & 6.00 \\
\hline Centaurea Candidissima, & silve & ry foliage & 1.00 & 8.00 \\
\hline Centaurea Gymnocarpa, $\mathrm{s}$ & silver & $y$ foliage & .75 & 6.00 \\
\hline Cobæa, Scandens & . & 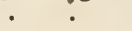 & 1.50 & 10.00 \\
\hline Coleus, fine varieties . & & . & .60 & 5.00 \\
\hline Coleus, new varieties, extra & & & t.00 & 8.00 \\
\hline Cuphea, cigar plant & & . & 1.00 & 8.00 \\
\hline rerfew double white fr & & & I.OO & 8.00 \\
\hline everfew, golden (golden fe & & ellow. & .75 & 6.00 \\
\hline uchsias, various fine sorts, & & & 1.20 & 9.50 \\
\hline
\end{tabular}

Geranium, double, red, rose, pink, and white $\cdot$ ingle, scarlet, white, pink, red

Geranium, single, bronzed-leaved

Geranium, single, silver-leaved .

Heliotropes

Lantanas, choice varieties

Lobelias, various sorts

Lemon Verbenas

Marigold, dwarf, French

Marigold, dwarf, African

Nasturtium, tall, for trellises, etc.

Nasturtium, dwarf, beds or borders .

Pansies, extra large flowered

Pansies, choice fancy, assorted colors

Petunia, double, choice varieties.

Petunia, single, dwarf or tall

Phlox, all colors

Salvia, scarlet for beds, etc.

Stocks, double, ten weeks

Verbena, assorted colors, extra

Vincas, red and white

Zinnias, assorted colors

\section{Doz.}

I. 50

I. 50

1.50
1.50

I. 50

I.oo

I. 00

.50

I. 50

.75

.75

.75
.75

.75

.50

I.00

I. 50

.75

.75

I. 50

I. 50

.75

I. 50

.75 soo.

8.00

8.00

8.00

8.00

8.00

8.00

4.00

10.00

6.00

6.00

6.00

6.00

4.00

8.00

10.00

6.00

6.00

10.00

10.00

5.00

10.00 5.00

\section{HARDY ASTERS.}

We have in this class some of the most showy, as well as really beautiful and interesting flowering plants in cultivation. All are quite hardy, graceful in habit, and bear such profusion of flowers that they are invaluable in the garden, especially as they blossom when the scarcity of hardy flowers is most marked. The color of the flowers has the widest range; all shades of white, blue, red, yellow and purple being included. Hardy asters will thrive in the grass or any rough spot and always bloom fully the first season planted.

A. Alpinus. 9 in. July. Bright purple.

A. Amellus Bessarabicus. $2 \mathrm{ft}$. Rich purplish-blue flowers with orange centre; one of the finest. $25 \mathrm{c}$.

A. Chapmanni. Numerous heads of small flowers of a light clear blue. I $5 \mathrm{c}$; $\$ \mathrm{I} .50 \mathrm{doz}$.

A. Ericoides. $3 \mathrm{ft}$. White with yellow centers, flowers in October; small, but very elegant. $15 \mathrm{c}$.

A. Horizontalis. Numerous branching stems smothered with red and white flowers; pretty, neat habit. I5c.

A. Hybridus Nanus. 18 in. A neat variety, and smothered with bright pink and white flowers. I5c.

A. Longifolius Formosus. 3. ft. October. A dwarfgrowing variety, which is a cloud of very large, bright, rose-colored blossoms; a superb aster. $25 \mathrm{c}$.
A. Multiflorus. $3 \mathrm{ft}$. Small white flowers in multitudes. I $5 \mathrm{C}$.

A. Novæ Angilæ. $4 \mathrm{ft}$. Our grandest American species, with thousands of big, violet-purple blossoms; a grand aster; $I_{5} \mathrm{C}$.

A. N. Roseus. $4 \mathrm{ft}$. A most charming variety of the above, with all shades of rose and crimson. The most magnificent of all hardy asters. $25 \mathrm{c}$.

A. Townshendi. It is one of the finest of the race; a really grand and beautiful aster, and one which should be grown in every collection. It is perfectly hardy, free flowering, growing $21 / 2$ feet, producing masses of large rich purplish-blue flowers with orange yellow centre. $25 \mathrm{c}$. 


\section{HELIANTHUS. - Perennial Sunflowers.}

These form a very important group of bold, showy autumn flowering plants, indispensable for large borders, woodland walks, planting shrubbery, etc.

H. Decapetalus. 5 feet. September to frost. Fine free-flowering form, with clear yellow flowers, immense panicles. $20 \mathrm{cts}$. each; $\$ 2.00$ per dozen.

H. Lætiflorus. A grand perennial sunflower; flowers large and of a rich dark yellow color, the disc also being yellow. Extra strong clumps. $25 \mathrm{cts}$.

$H$. Japonicus. This resembles in many respects $H$. rigidus, but is far the best of the two. The flowers are deeper in color, of a better formation, and about 3 weeks earlier in bloom. $20 \mathrm{cts}$. $\$ 1.50$ per dozen. H. Maximus. The Great Perennial Sunflower. An enormous growing variety, 6 to 7 feet, producing immense golden flowers, almost as large as the annual species. This should be grown in every garden where sufficient space could be found for it. The Garden says: "It is in our opinion the most beautiful of all sunflowers." $25 \mathrm{cts}$.

H. Plenus. This is the Double Perennial Sunflower, one of the most useful perennials we have. $20 \mathrm{cts}$.; \$2.0o per dozen.

H. Orgyalis. A remarkable species, to feet high, with foliage as long and narrow as willow leaves, and blooming latest of all, in October, at the tips, high up in the air. Exceedingly graceful and beautiful. $25 \mathrm{cts}$.

H. Multiforus Grandiplenus. The true variety, a very superior form with flowers much brighter and better shape than Multiflorus Plenus. $25 \mathrm{cts}$.

\section{PYRETHRUMS.}

A genus of very interesting, hardy herbaceous plants, which only require planting in the open border and the usual treatment of herbaceous perennials. The double varieties produce in abundance from May to September large Chrysanthemum-like flowers in a great variety of colors. The single sorts are similar to the double in foliage, growth, and free. flowering qualities.

\section{DOUBLE VARIETIES.}

Aurora. Sulphur white, with lemon centre. Captain Nares. Bright crimson.

Flora. Blush, large flower.

$$
25 \text { cents each; } \$ 2.50 \text { per dozen. }
$$

\section{SINGLE VARIETIES.}

Beatrix. Pink, base of petals shaded white. Coccinea, Rich reddish purple. Ghost. Pure white, large flower.

$$
25 \text { cents each; } \$ 2.50 \text { per dozen. }
$$

\section{CLEMATIS (Virgin's Bower).}

Elegant, slender plants of rapid growth, handsome foliage, and beautiful large flowers. Perfectly hardy, with a slighı root covering.

Miss Bateman. White; chocolate-red anthers. 50 cents and \$r.oo each.

Flammula (European Sweet Clematis). Flowers small, white, and very fragrant. 25 and 50 cents each.

Fortuneii. Double; rosette formed; creamy white; fragrant. 50 and 75 cents eacb.

Jackmanni. Large, intense violet.purple remarkable for velvety richness; free in growth, and an abundant and successive bloomer. 50 and 75 cents each.
Jackmani Alba. Like preceding, except in color, which is pure white. 50 and 75 cents each.

Lawsoniana. Large rosy purple, darker veins. 50 cents each.

Mrs. James Bateman. Pale lavender. 75 cents and $\$ 1.00$ each.

Virginiana (Amer. White Clematis). A remarkably rapid climbing plant, growing to the height of twenty feet, producing an immense profusion of flowers in August. 25 and 50 cents each.

\section{HARDY CLIMBING PLANTS.}

Actinidia Polygama. A strong, clean vine from Japan. 50 cents each.

Akebia Quinata. Of rapid growth, with shining foliage and bluish clusters of fragrant flowers. 35 and 50 cts.

Ampelopsis Englemanni. A variety of the Virginia Creeper, with bright foliage; fine color in the autuinn; and tendrils, which enable it to support itself like A. Veilchii. 25 and 35 cents.

Ameplopsis Quinquefolia (Virginia Creeper). Wellknown climber; very vigorous. 25 cents each.

Ampelopsis Veitchii (Boston Ivy, Japanese Ivy). Wellknown, particularly around Boston. It grows rapidly, and clings to a wall or fence with the tenacity of Ivy; the foliage is handsome in the summer, and changes to a crimson-scarlet in autumn. For the ornamentation of brick or stone structures, it can be especially recom. mended. 25 cents each; \$2.50 per dozen.

Bignonia Radicans (Trumpet Vine). A quick-growing vine, bearing large scarlet flowers, very brilliant. 25 and 50 cents each.
Celastrus Scandens (Roxbury Wax Work). A vigorous vine with conspicuous orange-scarlet berries in autumn. 35 and 50 cents each.

Euonymus Radicans. Variegata, retains its glossy green and white foliage through the winter; nice plants 25 and 50 cents.

Honeysuckle, Hall's Japan. Abundant, vigorous foliage retained until early winter, flower white and yellow, fragrant. 35 and 50 cents.

Honeysuckle, Scarlet. Strong, rapid growe1, bright scarlet. 35 and 50 cents.

Honeysuckle, Belgica. Dutch monthly, very sweet scented, red and buff. 25 and 35 cents.

Silk Vine. A rapid growing vine, will make 30 to 40 feet in a season. 35 to 50 cents each.

Wistaria Chinensis. One of the most elegant and rapid growing of all climbing plants, bearing long pendulus clusters of pale blue flowers in May and June. 50 and 75 cents each.

Wistaria Chinensis Alba. White, otherwise similar to preceding. 75 cents and $\$ 1.00$ each.

\section{HARDY FLOWERING SHRUBS.}

Almond (Prinus Jap. Rubra $f$. pl.). Double pink flowers. Large plants, 50 cents.

Almond (Prunus Jap. Alba f. pl.). Double white flowers, beautiful. 50 cents.

Althra purpurea plena (Rose of Sharon). Hibiscus. 35 and 50 cents each.

Althæa Striata. Carnation striped. 35 and $50 \mathrm{cts}$ each.
Althæa. Double variegated. 35 and 50 cents each.

Andromeda Floribunda. A pretty evergreen plant with rich, dark.green foliage, and pure white flowers in great abundance in spring. \$1.00 each; extra size, \$2.00 each.

Azaleas. Ghent Hybrids, perfectly hardy, and of many brilliant colors. Fine plants, \$1.00; large sizes, \$2.00 and $\$ 2.50$. 


\section{HARDY HERBACEOUS PERENNIAL PLANTS.}

This collection, retail value $\$ 12.95$, will be delivered free, as per Special offer No. 1 , on receipt of $\$ 10.00$.

Crass.

Achillea (Yarrow), double, white

Aconitum (Monkshood), blue

Adam's Needle. See Yucca.

Adonis (Pheasant's Eye), yellow .

Allium Moly (Golden Allium), yellow
Althea Rosea (Hollyhock); we have

a fine collection of the best double sorts of all shades

Alyssum Saxatile Compactum (Golden Tuft), bright yellow

Anem one Japonica (Japan Anemone), pink, yellow stamens

Anemone Japonica Alba (Honorine Jobert), large pure white flowers; continues to flower very late in fall .

Aquilegia Chrysantha (Golden Columbine), large, orange

Aquilegia Cœrulea(Columbine), beautiful blue and white .

Armeria (Thrift), pink; fine for bordering

Bell Flower. See Campañula.

Bleeding Heart. See Dicentra Spectabilis.

Bocconia Japonica, cream-colored flowers in pyramidal clusters

Campanula Garpatica (Carpathian Bell-flower), bright blue; compact

Columbine. See Aquilegia.

Coreopsis Lanceolata (Lance-leaved C.), bright yellow; a mass of flowers all summer, fine

Day Lily, Purple and White. See Funkia.

Delphinium Formosum (Perennial Larkspur), long spikes of bright blue flowers; splendid

Dianthus Barbatus (Sweet William) fine colors.

Dianthus Plumarius (Garden Pink), pink; fine for bordering . .

Dicentra Spectabilis (Bleeding Heart), pink and white

Dictamnus Fraxinella, purple, in spikes; whole plant strongly scented Erysimum Pulchellum (Treacle Mustard), bright yellow; for rock-work .

Eupatorium Argeratoides (White Thoroughwort), white

Euphorbia Corollat a (Flowering Spurge), pure white; fine for cutting

Evening Primrose. See Enothera.

Funkia Lanceolata (Purple Day Lily), racemes of light purple flowers

Funkia Subcordata (White Day Lily), white, fragrant .

Gentiana A caulis (Blue Gentian), rich blue; vase-formed, stemless

Golden Tuft. See Alyssum.

Helianthus $\mathrm{Multi}$ il or us, fl. pl. (Double Perennial Sunflower), hardy, double, golden-yellow; flowers three inches in diameter, profusely produced; very beautiful

Hemorcallis Flava (Yellow Day Lily), bright yellow; fragrant.

Hollyhock. See Althea Rosea.

Hyacinthus Candicans (Summerflowering Hyacinth), drooping, white flowers, 20 to 50 on a stem; a magnificent plant, entirely hardy here

Larkspur, Perennial. See Delphinium.

Leek, House. See Sempervivium

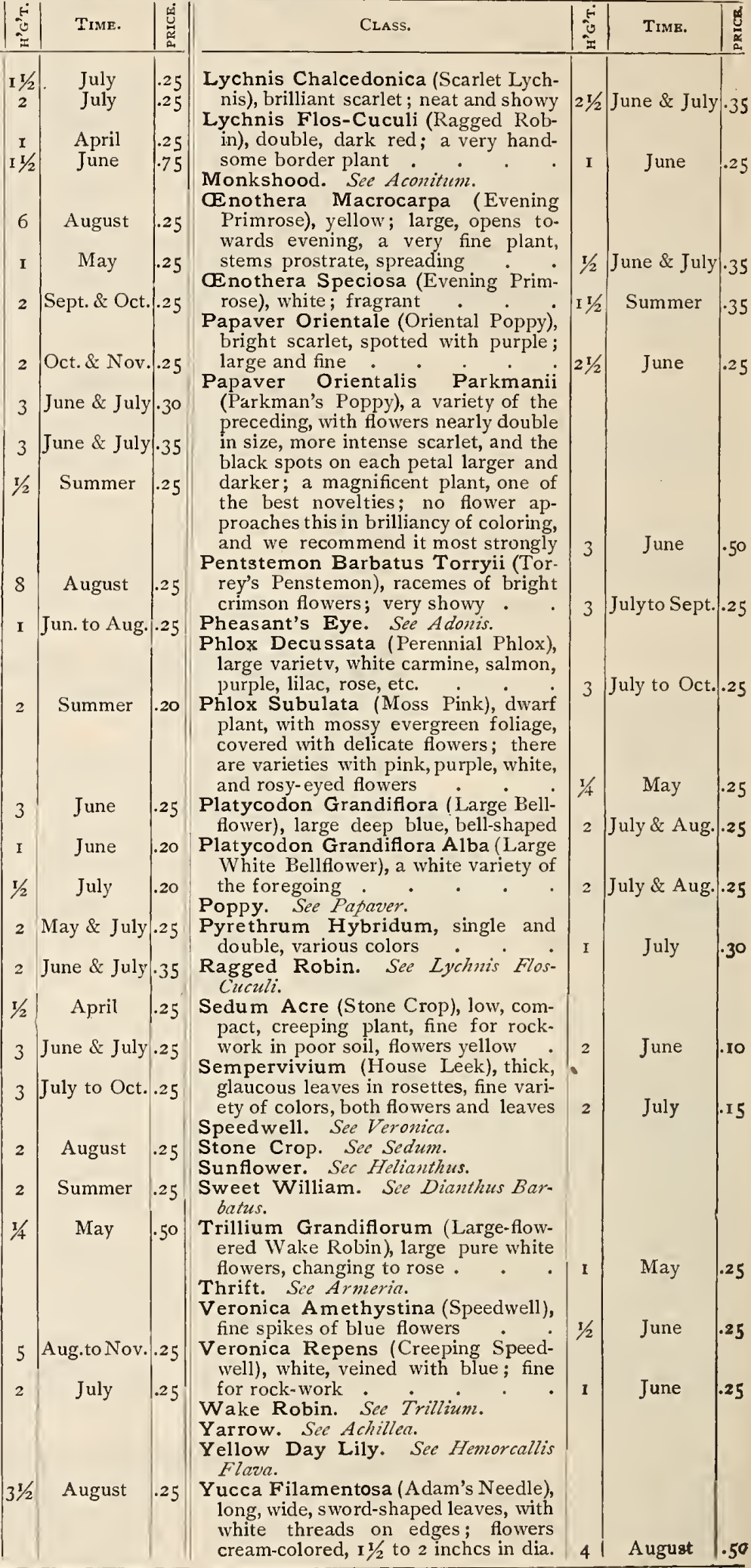




\section{HARDY FLOWERING SHRUBS, continued.}

Azalea Mollis. A new type, flowering earlier than the Ghent, and in color and form approaching the Indian varieties. 75 cents to $\$ 1 . Q 0$ each.

Barberry (Berberis Thunbergii). A low growing shrub of arching rabit; the foliage changes to many brilliant colors in the fall. Strong plants. 50 cents each.

Calycanthus Floridus. Strawberry tree or sweet scented shrub, dark flowers. 50 cents; small plants, 25 cents.

Corchorus Japonica (Kerria). A small shrub with brigh green leaves, and clear yellow flowers. 35 and $50 \mathrm{cts}$. each.

Cornus Elangantissima. With variegated foliags, the leaves are marked with silvery white, very attractive. 50 cents each.

Daphne Cneorum. A low growing evergreen, produces panicles of bright pink flowers. 50 cents each.

Deutzia Gracilis. Compact, filled with starry white flowers. 35 and 50 cents each.

Deutzia Crenata fl. pl. Flowers double white, tinged with rose. 35 and 50 cents each.

Deutzia C. A. Alba pl. With very. double pure white flowers. 35 and 50 cents each.

Elder, Golden. Very effective for its bright yellow foliage. 25 and 50 cents each.

Eleagnus Longipes. A new fruit-bearing ornamental shrub from Japan, a decided novelty. 75 cents each.

Exochorda Grandiflora. A choice shrub of strong upright growth, producing a profusion of large, snowywhite flowers in June. 50 and 75 cents each.

Forsythia Suspensa. Trained as a standard, it becomes one of the most beautiful weeping shrubs, covered with bright golden yellow blossoms early in summer. Dwarfs, 25 and 50 cents each; standards, 75 cents and $\$ 1.00$ each.

Hydrangea, Paniculata Grandiflora. Flowers white in great pyramidal panicles, about a foot long. 50 cents, 75 cents, and $\$ 1.00$ each.

Kalmia Latifolia. A choice native evergreen shrub with shining foliage, and dense clusters of pink or nearly white flowers. \$1.00 to \$1.50 each.
Lilac (Syrinca). Common bluish purple flowers. 25 and 50 cents each.

Lilac $(S . A l b a)$. Pure white. 25 and 50 cents each.

Mock Orange or Syringa (Philadelphus). Of compact habit, with creamy white flowers, deliciously fragrant. 35 and 50 cents each.

Mahonia Aquifolia. A handsome shrub witl shining prickly leaves, and showy bright yellow tlowers in May. followed by large clusters of purple berries. 25 cents each.

Pyrus Japonica (Cydonia). Japan Quince, flowers bright scarlet, very showy. 25 and 50 cents each.

Rhus Cotinus. The well-known smoke bush. $3 \mathrm{ft}$., $25 \mathrm{cts}$.; $5 \mathrm{ft}$., $50 \mathrm{cts}$. each.

Spiræa Aurea. Frequent pinching produces a deep golden yellow color. 35 and 50 cents each.

Spiræa Thunbergii. Dwarf, flowers early, very pretty. 35 and 50 cents each.

Spiræa Van Houtti. The most profuse flowering of all the Spiræas, the bush being a mass of white bloom. 35 and 50 cents each.

Snowball (Viburuum Plicatum). A great improvement on the old-fashioned sort, with dark green foliage, and superb trusses of white flowers in midsummer. 50 and 75 cents each.

Weigelia Rosea. Well known, very free-flowering. 35 and 50 cents each.

Weigelia Lowii. This variety has dark crimson flowers with white stamens, very free-flowering. Strong plants. 5o cents each.

Xanthoceras Sorbifolia (nezo). Introduced from Mon golia, one of the most important introductions of the last few years; forms a shrub or small tree, flowers five petaled, white, copper colored at base, disposed in racemes about 8 inches long. Strong plants. $75 \mathrm{cts}$. each.

\section{RHODODENDRONS.}

We draw our supply of Rhododendrons from what we believe to be the finest stock in the world. All the plants even the small sizes, are symmetrical in form, well furnished, and have good fibrous roots that make transplanting comparatively safe.

Rhododendron Catawbiense. A profuse flowering and perfectly hardy native sort, is the parent of all our hardy named varieties, it having been hybridized with $R$. Arboreum. The plants are of syinmetrical shape, and seldom exceed 4 feet in height. The varieties embrace colors from nearly pure white to dark crimson. All the hardy sorts are of easy culture, growing freely in almost any good loamy soil, but they prefer a peat soil, and a moist situation, protected fron cold winter winds. IVhen first planted, they should be mulched to prevent evaporation, and to keep the roots cool.

Alarm; white with crimson edge.

Aurora, light rose, large truss.

Album Elegans, blush, changing white.

Barclayanum, deep rosy crimson.

Blandyanum, rosy crimson.

Chas. Bagley, cherry red.

Chas. Dickens, dark scarlet.

Concessum, clear pink.

Duchess of Sutherland, rosy lilac.

Everestianum, rosy lilac.

John Waterer, dark crimson.

Lady Eleanor Cathcart, pale rose.

Lady Francis Crossley, rosy pink.

Lady Strangeford.

Lord Paimerston, rosy crimson.

Mrs. Frederick Hankey, rich salmon.

Mrs. John Ciutton, pure white.

Mrs. John Waterer, bright rose.

Mrs. R. S. Holford, rich salmon.

Mrs. William Bovill, fine rosy scarlet.

Old Port, distinct rich plum.

Perfection. blush, vellow-eve.

Princess Mary of Cambridge, light blush.

Rosabel, pale rose, fine habit.

Sir Chas. Napier, light rose.

Sir Chas. Seabright, riclı purple.

Sultana, white.

The Queen, blush, changing to white.

\section{PRICES}

Good Plants, 18 to 20 inches, budded, $\$ 1.00 ;$ per hundred, $\$ 85.00$. Strong Plants, 20 to 24 inches, budded, \$1.50; per hundred, $\$ 125.00$. Extra Plants, 24 to 30 inches, budded, $\$ 2.00$; per hundred, $\$ 175.00$.

\section{EVERGREENS.}

Arbor Vitæ (Thuja occidentalis). Common American form. 25 cents, 50 cents.

Fir Balsam (Abies balsamea). Erect, regular pyramidal tree, rapid grower,very hardy. 50 cents to $\$ 1.00$ each.

Fir, Douglass. Hardy, and very ornamental. Price
Fir Nordmann's. Dark rich green foliage, silvery underneath. I I 12 feet, $\$ 1.00$ each; 3 feet, \$5.00 each.

Juniper Virginiana (Red Cedar). Native variety. 3 feet, 50 cents; 5 feet, $\$ 1.00$

Pine, Swiss Stone ( $P$. Cembra). Short needles, compact growth, very attractive. 3 feet, \$1.00. 


\section{EVERGREENS, continued.}

Pine, Austrian. Stout growth, long needles, perfectly hardy in bleakest exposure. I ft., $25 \mathrm{cts}$.; $3 \mathrm{ft}$., $75 \mathrm{cts}$. ea. Pine, White ( $P$. Strobus). The most ornamental of all our native pines. 2 feet, 50 cents; 5-6 feet, $\$ \mathbf{1} .00$ each.

Retinospora Aurea (Cypress). Of bright golden color. 3 feet, \$I.oo.

Retinospora Plumosa. Very hardy, with graceful plumelike foliage. 3 feet, 50 cents; $4-5$ feet, $\$ 1.00$.

Spruce, White (Picea $A l b a$ ). A very hardy native tree. 2 feet, 50 cents; 3 feet, \$I.0O.

Acacia, Three Thorned. Beautiful foliage, makes a strong and fine defence. $\$ 8.00 ; 3$ years, $\$$ Io.oo per 100.

Arbor Vitæ, American. Stocky plants. I-I $1 / 2$ feet, $\$ 10.00$ per 100.

Barberry. Common kind, fruit is very conspicuous in the fall and winter. 2 years, $\$ 6.00$ per 100 .

Barberry, Purple. Foliage soft purple, very beautiful. I foot, \$10.00 per IOO; 2 feet, $\$ 15.00$ per 100.

Buckthorn. Makes a hardy and strong defence. 2 years, $\$ 8.00 ; 4$ years, $\$ 15.00$ per 100 .

\section{SHADE AND ORNAMENTAL TREES.}

Apple, Japan Crab (Malus Halleana). Also sold under the name of Parkman's Crab, a beautiful variety pro. ducing long, pink flower-buds, quite conspicuous. 50 cents, 75 cents, and $\$ 1$. Oo each.

Ash, American White (Fraxinus Alba). A large, noble tree, Io feet, 75 cents; 12 feet, $\$$ I.00.

Ash, Weeping (F. Pendulá). A beautiful tree of irregular form. 6-7 feet, \$1.oo.

Ash, Mountain (Sorbus Americana). Very ornamental, bearing large clusters of shining red berries. 6-7 feet, 50 cents; IO feet, \$1.00.

Beech, American (Fagus Feruginea). Compact form, with rich, glossy, attractive foliage. 5 feet, 50 . cents; 7-8 feet, \$I.oo.

Beech, Rivers Purple ( $F$. Atropurpurea). The finest of all purple-leaved trees, beautiful as single specimens. 4 feet, \$1.50.

Beech, Cut Leaved ( $F$. incisa). Distinct and fine. 4 feet, $\$ \mathbf{I} .00$.

Beech, Weeping (F. Pendula). A remarkable picturesque tree of curious growth. 4-6 feet, $\$ \mathbf{I} .50$.

Birch, European White (Betula Aiba). A graceful tree with silvery bark, and slender branches, and elegant drooping habit. Price, $4-5$ feet, 50 cents; $7-8$ feet, $\$ \mathbf{I}$.00.

Birch, Canoe ( $B$. papyracea). A native variety which attains great size. 5 feet, 50 cents; 8 feet, $\$ \mathbf{I} .25$

Birch, Cut Leaved, Weeping ( $B$. pendula laciniata). One of the most popular weeping trees, most beautiful as single specimens on the lawn. 5-6 feet, \$1.00. 8-10 feet specimens, $\$ 2.00$.

Catalpa Speciosa. A Western type, very desirable, being more hardy and finer in bloom than the common variety. $6-7$ fect, 75 cents.

Chestnut, American (Castanea Americana). A tree of stately growth, very ornamental. 4-5 feet, 50 cents; 8 feet, \$1.00.

Chestnut, Horse (Esculus Hippocastrum). Strong habit, magnificent foliage, and fine spikes of flowers in May and June. 4-5 feet, \$1.00; 6 feet, \$1.50.

Cornus, Florida. Of fine form, very effective when covered with its large, white, broad-petaled flowers. 4 feet, 75 cents.

Cornus, F. Rubra. Same as above except in color, which is bright red, very showy. \$I.oo.

Elm, American (Ulmus Americana). The noble spreading and drooping tree of our own forests. 10-I 2 feet, $\$$ I.OO; I 5 feet, \$I.5O.

Elm, English ( $U$. Campestris). An erect, lofty tree of rapid, compact growth. 8-10 feet, \$1.00; I5 feet, $\$ 2.00$.

Hawthorn, Double White (Cratagus Alba $f l$. pl.). Highly ornamental flowers and foliage. 6 feet, \$1.50. Choice specimens, $\$ 2.00$. 100; 2 feet, $\$ 15.00$ per 100 .

\section{HEDGE}

Spruce, Colorado ( $P$. Pungens). Perfectly hardy, pyra. midal in shape, foliage of a dark steel-blue color. I foot, 75 cents to $\$ \mathbf{I} .00 ; 2$ feet, $\$ \mathbf{I} .00-\$ 2.00 ; 4$ feet, $\$ \mathbf{I} .50$ to $\$ 3.00$, according to color.

Spruce, Norway (Abies Excelsa). An elegant tree, extremely hardy, of lofty, rapid growth, and pyramidal form. 2 feet, 50 cents; 5 feet, $\$ 1.00$ each.

Spruce, Hemlock (Abies Canadensis). Of good shape and habit. 3 feet, 50 cents; 5 feet, \$1.00 each.

\section{PLANTS.}

California Privet. Of rapid growth, very hardy. \$10.00 per 100.

English Privet. Hardy and very desirable. $\$ 10.00$ per 100.

Lilacs. The standard purple. 2-3 feet, $\$ 10.00$ per .100.

Lilacs, Chinese White. \$15.00 per I00.

Spruce, Norway. Unsurpassed for windbreaks or screens. Small plants, $\$ 10.00$ per $100 ; 2$ feet, $\$ 15.00$.

Spruce, White. Rapid grower. Small plants, $\$$ Io.00 per

Hawthorn, Paul's Scarlet ( $C$. coccinea $f$. pl. P'aulii). Flowers bright carmine, red, makes a striking contrast when planted with the white. $5^{-6}$ feet, $\$ 1.50$; Choice specimens, \$2.50.

Laburnum, Golden (Cytisus). A small tree producing freely long clusters of the brightest golden-yellow blos. soms, of sweet-pea size and shape. 4 feet, 50 cents; 5-6 feet, \$1.00.

Larch, European (Larix Europcea). An elegant, rapidgrowing, pyramidal tree. 4-6 feet, 75 cents.

Linden, American, or Basswood (Tilia Americana). A beautiful, rapid-growing, native tree with large leaves and fragrant flowers. 8 feet, 75 cents; 10 feet, $\$ \mathbf{I}$.oo.

Linden, European (T. Europaa). Pyramidal tree of larger size. $7-8$ feet, 75 cents; 8-ro feet, $\$ 1.00$.

Maple, Cut Leaved Weeping (Acer Wierii Laciniatum). A weeping silver-leaved variety with deeply cut foliage. 8 feet, \$I.oo.

Maple, Japan (Atrosanguineum Purpureum). This is the richest crimson and the most brilliant, vigorous, and the best type of the Japanese varieties. \$2.00 each.

Maple, White or Silver-Leaved (A. Dasycarpum). A native variety of rapid growth, very beautiful. 8-Io feet, 75 cents; IO-I 2 feet, $\$ 1.00 ; 13-15$ feet, $\$ 2.00$ each.

Maple, Norway (A. Plantanoides). Of spreading habit, foliage dark green. 8 feet, $\$ \mathbf{I . 0 0 ;}$ io feet, $\$ \mathbf{I} .25$ each.

Maple, Sugar (Acer Saccharinum). Of vigorous growth, one of the best street trees. IO-I 2 feet, $\$ 1.00 ; 12-15$ feet, \$I.50.

Magnolia Acuminata (Cucumber $M$.). Of pyramidal growth, flowers yellow, tinted with bluish purple. Fine specimens. 5-6 feet, $\$ 1.00$.

Magnolia Macrophylla. Bearing leaves of immense size, and large white flowers. Fine specimens, $\$ \mathbf{I} .50-\$ 2.00$.

Magnolia Conspicua (Chinese White). A variety of great beauty; the flowers are large, pure white, and appear before the leaves. \$I.50-\$2.00 each.

Magnolia Soulangeana. Flowers white and purple, cup. shaped; foliage, large and glossy. Fine specimens, $\$ \mathbf{I} .5^{\circ}$ to $\$ 2.00$ each.

Mulberry, Downing's Everbearing (Morus). A rapidgrowing tree which bears nice fruit. $4-5$ feet, $\$ \mathbf{I} .00$.

Mulberry, Teas' Weeping. Absolutely hardy and free from disease, very vigorous in growth. 2 years old heads, $\$ 1.50$.

Oak White (Quercus Alba). One of the finest of American trees, of large size and spreading branches. $\$ 1 . \infty$ each.

Oak, Red (Q. rubra). A native species of rapid growth. $\$ 1.00$ each.

Special Offer No. 2 only applies to articles on this page. 


\section{SHADE AND ORNAMENTAL TREES, continued.}

Poplar, Bolleana (Populus). Pyranidal growtl. S'-Io ft., $\$ 1.00$

Poplar, Lombardy ( $P$. fustigiuta). Well known and remarkable for its erect rapid growth. $6-8 \mathrm{ft}$., 50 cents;

$8-10 \mathrm{ft} ., 75$ cents.

Prunus Pissardi. One of the best novelties of ldie years. The wood and leaves are dark purple throughout the entire season. $5 \mathrm{ft}$, 50 cents; $\mathrm{S}-\mathrm{IO} \mathrm{ft}$. $\$ \mathrm{I} .50$ each.

Syringa Japonica (Giant tree lilac). It makes a stout tree with large rich foliage, and throws up well above the leaves large clusters of white flowers about a foot long $2-3 \mathrm{ft} ., 75$ cents each.

Willow, Kilmarnock (Sulix caprea pendula). An exceed. ingly graceful tree with glossy foliage and perfect umbrella head $\$$ r.oo each.

Willow, White $(S . A l b a)$. Rapid grower. Valuable for seashore. $0-8 \mathrm{ft}$., $50 \mathrm{c}$; $10 \mathrm{ft}$., $75 \mathrm{c}$.; $12-14 \mathrm{ft}$., \$1.00 each.

Willow (S. Babylonica). Great Weeping IVillow. An immense and beautiful tree with bright green foliage and pencient branches. $6 \mathrm{ft}$., 35 cents; $8 \mathrm{ft}$., 50 cents each.

\section{FRUIT TREES.}

\section{APPLES.}

We can furnish all varieties usually catalogued, but the following list comprises the most desirable sorts.

\section{SUMMER.}

Astrachan, large, crimson, very early.

Early Harvest, pale yellow, excellent, early.

Sweet Bough, large, pale yellow.

Williams, dark red, nild flavor.

\section{AUTUMN.}

Gravenstien, large yellow, striped red.

Fameuse (Snow apple), crimson, flesh white, excellent.

Porter, medium, bright yellow, good.

Pippin, fall, yellowish green, very fine.

\section{WINTER.}

Baldwin, large, dark red, productive, medium. Golden Russet, medium, yellow, good flavor.

\section{CRAB-APPLES.}

Hyslop, October to January; deep crimson Red Siberian, September to October; small, red.
Hubbardston, large, yellow, splashed red, early.

King, large, striped red, excellent.

Lady, small, yellow and red, good.

Northern Spy, large, striped red, good keeper.

Rhode Island Greening, large, yellowish green, medium.

Roxbury Russet, extra quality, largest of the russets.

Tolman's sweet, medium, light yellow, excellent.

Murphy, of good size, "better than Baldwin," ripens in December and January, but can be kept until April, bears reginarly every year, and an experienced and most careful judge says of it that he "does not know of an out about it." We offer a limited number of two-year old grafts at 50 cents each.

Price 35 cents, 50 cents, 75 cents, and $\$ 1.00$, according to size.

\section{SUMMER. \\ A UTUMN.}

PEARS

We can supply all varieties. Following are the leading kinds.

Clapp. Very productive; large, juicy, and rich.

Bartlett. Large, clear yellow, juicy; late.

Doyenne d'Ete, Early, small; dotted red.

Gifford. Medium; greenish yellow, juicy, good.

Beurre Hardy. October; large, greenish russet.

Belle Lucrative. September; yellowish green, juicy, melting.

Bosc. October ; large, russet, buttery, rich.

Comice. November; large, greenish yellow, juicy, mellow.

Duchess d'Angouleme. October; very large, greenish, very good.

Howell. October; large, light yellow, melting

Louise Bonne. October; large, pale yellowish and red, juicy.
Transcendent, Sept. to Oct. ; striped, red and yellow.

Price 35 cents, 50 cents, and 75 cents each, according to size
Seckel. September; small, dull brown, red-cheeked, sweet.

Sheldon. November; large, russet brown, very juicy.

\section{WINTER.}

Anjou. November - January; large, greenish yellow ; red cheek, rich, high flavor.

Dana's Hovey. November; small, rusty yellow, rich, juicy.

Lawrence. January; medium, pale yellow, sweet.

Nellis. January; medium, of excellent quality.

Vicar. December; very large, yellowish green; cooking.

Wilder. New variety; ripens about August 1; of superior quality, free from rot at the core, very productive, and of the best flavor imaginable. \$1.00-\$1.50.

Price, standards $5-7$ feet, selected, \$o.75 Bearing trees, $\$ 1.50$ and $\$ 3.00$.

\section{PEACHES.}

\section{EXTRA EARLY.}

Amsden. July; greenish white and red, sweet, melting. Alexander. July; medium, melting, juicy.

Waterloo. Juiy; flesh whitish green with red, very juicy.

\section{EARLY.}

Large Early York. August; large, handsome, white and red, juicy.

Coolidge's Favorite. August; medium, juicy, rich, freestone.

Mountain Rose. September; large, white and red melting, good.
Crawford's Early. September; large, yellow, juicy, freestone.

Foster. September; similar to preceding, but of better quality.

Old Mixon. Sept.; large, white and red, juicy and rich.

\section{LATE.}

Crawford's Late. September; very large, juicy, good, freestone.

Late Rareripe. September; large, white, very good.

Stump the World. September; medium, red and white good.

Price, 4 to 6 feet, 25 cents; large size, 50 cents.

Special Offer No. 2 only applies to articles on this page. 


\section{CHERRIES.}

Coe's Transparent. June; medium, pale amber and red.

Black Tartarian. June; large, purplish black.

Black Eagle. July; large, tender, rich, juicy.

Downer's Red. July; light red, tender and juicy.
May Duke. June; large, dark red, tender, sub-acıa. Black Heart. July; medium, black, fine flavor.

Late Duke. July; large, dark red, sub-acid. Price, 75 cents and $\$ 1.00$ each.

\section{PLUMS.}

Coe's Golden. September; large, light yellow, firm, rich and sweet.

Green Gage. September; large, greenish yellow, very fine.

Imperial Gage. August; large, greenish, juicy, and rich.

Jefferson. August; large, yellow and red, high flavor.

Lombard. September; medium, violet, rea, juicy.

Washington. Price, 75 cents and $\$ 1.00$ each.

\section{QUINCES.}

Orange or Apple. Large, roundish, bright yellow, productive.

Rea's Mammoth. A fine variety; golden yellow.

Champion. Vigorous and productive.

Meech. Comparatively new; quality unsurpassed. Price, 50 cents, 75 cents and $\$ 1.00$ each.

\section{APRICOTS.}

We offer six varieties that are perfectly hardy in New England. Price, $3-4$ feet, 40 cents each; set, six varieties, \$2.00.

\section{CLEMATIS PANICULATA.}

A comparatively new variety introduced only a few years ago. It is perfectly hardy, a rapid grower, and invaluable for covering porches or trellis work. It resembles our common wild Clematis, but the blossoms are produced in greater profusion of pearly whiteness and deliciously fragrant. It continues to flower late into September, when we have few shrubs and climbers in bloom.

Strong plants, 50 cents and 75 cents $; \$ 5.00$ and $\$ 8.00$ per dozen.

\section{HERBACEOUS PAEONIES.}

A wonderful change has been brought about in this class of plants by the hybridizers, who have introduced many new shades and tints, making the Prony one of the leaders among hardy Perennials, on account of its showy and gorgeous colors.

They are of easy culture, requiring only a deep rich soil. We can supply strong plants of the different varieties, in shades of crimson, violet-purple, lilac, rose-pink, white, white tinted rose, red, scarlet-crimson.

Price, 50 cents each; $\$ 5.00$ per dozen.

\section{TREE PAEONIES (Paeonia Moutan).}

A very showy class, perfectly hardy and of easy cultivation, earlier than preceding sort, and very free bloomers. In many colors, including dark purple, crimson, rose, salmon, scarlet, pure white, etc.

Price, strong plants, \$1.50 and $\$ 2.50$ each.

\section{HARDY் PHLOXES.}

A class of bright and showy hardy Perennials, producing large heads of bloom of great beauty, and every conceivable color from snow-white to purple, through the shades of rose, salmon, red, and crimson, many sorts being marked with a distinct eye.

Price, 25 cents each; $\$ 2.50$ per dozen.

\section{HOLLYHOCKS, SILVER MEDAL STRAIN.}

This strain has been awarded a silver medal by the Massachusetts Horticultural Society, and always obtained the first prize wherever exhibited. No other collection can approach this in variety of shades of color, length of spikes, profusion and texture of flowers and foliage.

We ofler a fine lot of strong healthy plants raised from seed obtained from the originator, in all shades of white, carmine, dark maroon, salmon, apple-blossom, light and dark crimson, rose, yellow, purple, and variegated.

Price, in separate colors, 30 cents each; $\$ 3.00$ per dozen; $\$ 20.00$ per 100.

Price, mixed sorts, al: colors, 25 cents each; $\$ 2.50$ per dozen; $\$$ r 8.00 per 100. 


\section{SMALL FRUITS.}

\section{HARDY GRAPES.}

We can supply all the really valuable sorts; the following varieties we can recommend for general culture;

Brighton, September; red, sweet, excellent.

Concord, well known, very popular.

Delavare, September; small, unsurpassed quality.

Eaton, large, black, very juicy. \$1.00 each.

Green Mountain, extra early, productive, strong. I year vines, $\$ 1.5(1 ; 2$ years, $\$ 2.00$

Hayes, white, sweet, juicy, good.

Jefferson, large, bright-red, juicy; price, $50 \mathrm{cts}$.

Moore's, early, large, black, earlier than Concord.

Moyer, a new red variety from Canada, a cross between the Delaware and some native sort, juicy and sweet, hardy and productive plants; 1 year old, 50 cents; 2 years olıl, $\$ 1.00$.

Niagara, large, white, inelting sweet.

Pocklington, pale yellowish green, very sweet; $50 \mathrm{cts}$.

Potter's Sweet, Sept.; black, very sweet; \$I.50 each.

Vergennes, large, dark-red, sweet, juicy.

Worden, black, very productive, good flavor.

Price, except when noted, I year vines, $35 \mathrm{cts}$.; 2 years old, $50 \mathrm{cts}$.

\section{GRAPE VINES FOR GRAPERIES.}

The plants we offer were raised from cuttings of BEARING vines, and all grown in pots. During the last fifty years we haye supplied thousands of vines to cultivators in all parts of the country. The following are the leading varieties:-

Black Alicante, berries large, good keeper.

Black Hamburg, well known as one of the best.

Buckland's Sweetwater, amber colored, large berries. Canon Hall, white, extra flavor.

Foster's Seedling, excellent quality, white.

Golden Hamburg, white, extra bunches, very fine.

Lady Downes, large bunches, fine keeping grapes.

Muscat of Alexandria, very fine.

Muscat of Hamburg, fine, large bunches.

Price, $75 \mathrm{cts}$. each. $\$ 8.00$ per dozen. Extra size, $\$ \mathrm{I} .50$ to $\$ 2.00$ each.

\section{BLACKBERRIES.}

Early Harvest, extra early, productive $\begin{aligned} & \text { Per doz. } \$ 1.00 \quad \$ 5.00 \\ & \$ 1.00\end{aligned}$ Dorchester, very early, rich, and sweet . I.00 6.00 Taylor's Prolific, very large, superior qual. I.00 6.00

Wachusett, hardy, good size and qual. $\begin{aligned} & \text { Per doz. } \$ 1.00 \\ & \$ 5.00\end{aligned}$

Lucretia Dewberry, a trailing variety of immense size, sweet and luscious . I.00 6.00

\section{CURRANTS.}

Cherry, large, red, juicy, acid

Fay, like cherry, but more prolific

La Versaillaise, very large, red

Red Dutch, a well-known variety

Smith's Improved, large, light green Industry, very large, dark cherry red

\begin{tabular}{|c|c|}
\hline $\begin{array}{r}\text { Per doz. } \\
\$ 1.00\end{array}$ & $\$ 77.00$ \\
\hline $2.5^{\circ}$ & \\
\hline 1.00 & \\
\hline 1.00 & \\
\hline
\end{tabular}

White Dutch, the least acid kind

White Grape, a fine variety

Crandall, an improved sort, fruit very

\section{GOOSEBERRIES.}

Each. Per doz.

\$o.20 \$1.50

$.25 \quad 2.50$

RASPBERRIES.

Perdoz. $\quad 100$

$\$ 1.00 \$ 5.00$

I.00 5.00

Shaffer's Colossal, of immense size

Perdoz. 100

$\$ 1.00 \quad \$ 700$

$1.00 \quad 7.00$ large. $25 \mathrm{cts}$. each; $\$ 2.50$ per doz.

\section{$1.00 \quad 5.00$}

Cuthbert, red, firm, and superior quality Hansell, early, crimson, fine quality

\section{STRAWBERRIES}

We consider the following the best system for cultivating the strawberry:

Set your plants about one foot apart in the rows, and the rows three feet apart (it would take about fifteen thousand plants per acre at this distance), and allow them to make runners to fill up a space of about twelve to fourteen inches wide; that would give you a space about twenty-two inches wide for a path.

It is claimed that one can get two thousand quarts more fruit off the same ground grown in these narrow rows than by allowing them to run all over the ground, and the fruit is of better quality.

They should have from fifteen to twenty cords stable manure per acre, or one ton of ground bone, one-half ton muriate of potash, and four hundred pounds nitrate of soda to be thoroughly worked into the soil.

In field culture they should be worked once a week with cultivator, and gone over by hand once in two weeks: care should be taken after runners start, to work cultivator always the same way, to prevent breaking runners.

They should be mulched in fall after ground is frozen to protect from thawing and freezing during winter, and part of the mulch should remain during fruiting season.

Any good corn land will raise strawberries if properly fertilized.

For garden culture, set plants one foot apart in the row, and the rows two feet apart, keep the runners cut off and otherwise carry out the instructions as given above.

The varieties marked " $P$ " are pistillate, and nuust have a row of staminate, of perfect-flowered varieties, planted say every ten feet among them. Those not marked "P." are staminate of self-fertilizing varieties.

Belmont (S.), a strong growing sort, dark crimson, Marshall berries, very dark crimson, fine flavor, and one of the best.

Bubach, No. $5(P$.$) , a productive, bright scarlet varie-$ ty, good carrier.

Haviland $(P$.$) , bright, glossy crimson, good quality,$ excellent grower, very productive on heavy soils.

Leader $(S$.$) , an extremely large berry, bright crimson$ in color, fine grain, exceedingly early, and continues in fruit a long time. $\$ 1.50$ per 100 .

Lovetts $\left(S_{.}\right)$, an all-round general purpose berry, extra for shipping and table uses; berries bright crimson, remarkably firm, specially recommended as a fertilizing sort for pistillate kinds. good keeper, immensely productive; awarded first prize by Mass. Hort. Society. Doz., $\$ 2.50$; pot plants same price in August.

Parker Earle (S.), a new variety from Texas. A great producer of bright crimson fruit of extra quality. IOO, \$I. 50 .

Shusters Gem. $(P$.$) , fruit large, beautiful bright scarlet,$ very vigorous grower, easily adapts itself to any soil or location.

Wolverton (S.), good size, and free from rust, deep scarlet in color.

Price, 30 cts, per doz.; \$1.00 per I00, except as noted. Special Offer No. 2 only applies to articles on this page. 


\section{LABOR SAVING ITMPLETMENTS}

$\longrightarrow$ FOR THE -

\section{FARM, GARDEN, LAWN AND GREENHOUSE.}

COR the season of I 894 our aim has been to bring to your notice a line of the finest labor- saving implements invented, and to this end have added to our already large assortment, several articles that are first class in every respect, and that cannot fail to give satisfaction.

We trust you will examine the following pages carefully, as we think you cannot fail to find something particularly adapted to your wants for the coming season. In addition to the goods mentioned, we have in stock everything needed for the Farm, Garden, Lawn and Greenhouse, and any orders entrusted to us will receive prompt and careful attention, and the goods sent you will be the best the market affords.

\section{AT R LOGUES.}

Our illustrated catalogues of Agricultural Implements, Machines, Dairy and Stable Supplies and Woodenware, embraces in its two hundred and sixteen pages a description of the leading farm implements and illustrations of the same, making it valuable as a work of reference to every farmer. Mailed on application.

Wm. T. Wood \& Co.'s catalogue of Ice Tools and circulars, covering all information pertaining to ice harvesting in all its branches, mailed on application.

Catalogues or circulars relating to any of the implements sold by us, whether shown in the following pages or not, will be promptly mailed, and; we will quote low prices if you will write; stating the implement or machine you are in search of.

\section{SPECIAL OFFERS.}

See $\mathrm{T}$ hird Page of Cover.

They apply on Implements and Machines just the same as on Seeds, Plants, Fertilizers, etc.

\section{BEE SUPPLIES.}

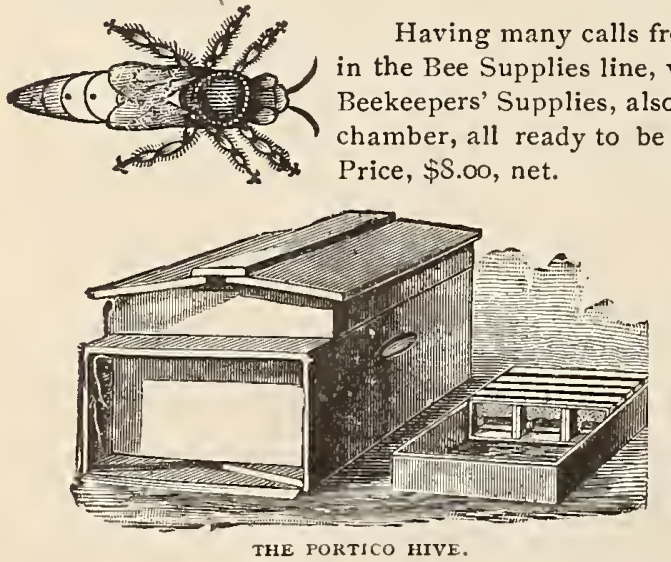

Portico Hive, complete, consists of body with bottom, one-half story cover, ten brood frames with foundation, enamel cloth, honey board, section case filled with one-pound sections, with starters, separators, etc., everything all ready for the bees. Price, $\$ 3 \cdot 50$, net.

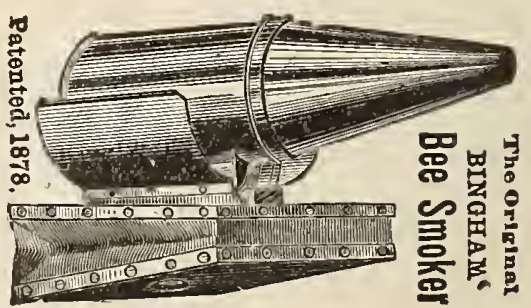

\section{THE BINGHAM BEE SMOKER.}

We have in stock the sizes for which there is the most demand, and that give the best satisfaction.

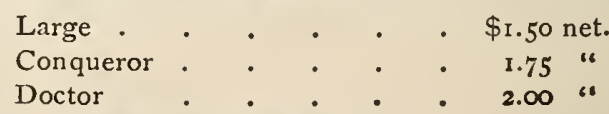




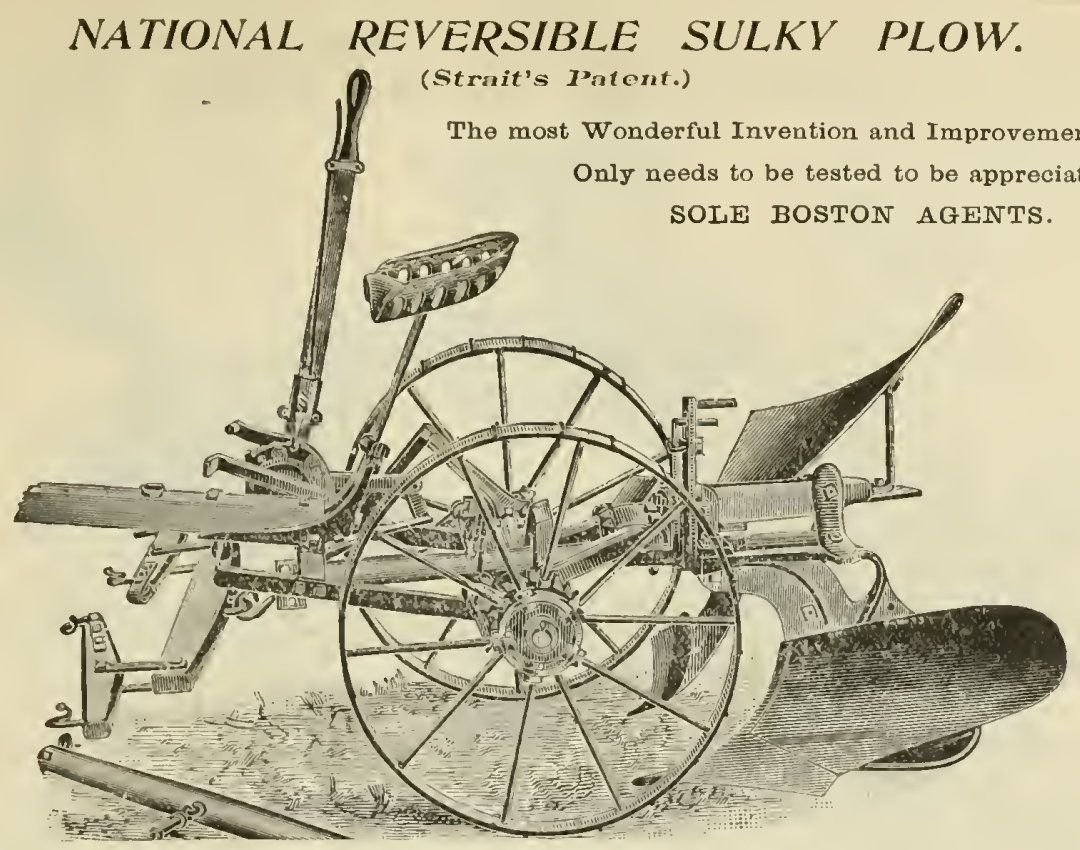

Thousands in use, of light draught, and easily handled. The Only successful Sulky Plow made that will plow stony, rough, side-hill or level land.

PRICE LIST.

National Plow with extra points.

Not included in our special Offer.

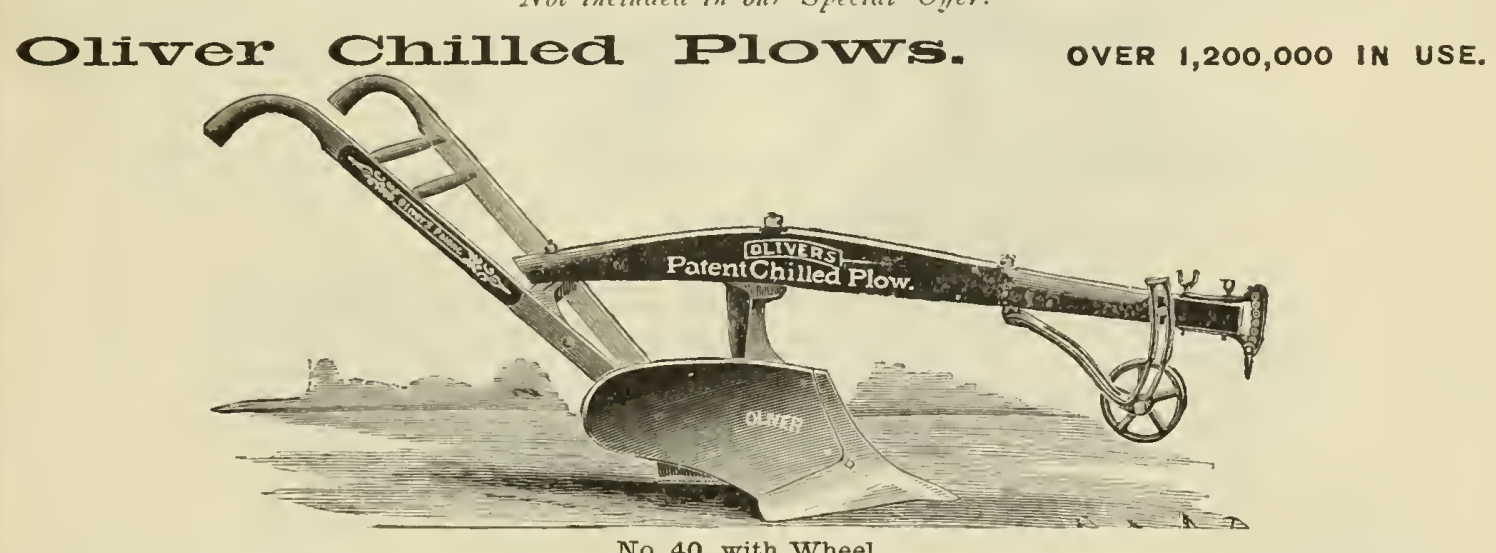

No. 40, with Wheel.

The Oliver Chilled Plow has been before the public for a number of years, and the steadily increasing sales and flattering reports from farmers to whom it has been sold, and the trade generally, justifies us in the belief that it is the best plow in the world.

Joseph Breck \& Sons' Net Cash Price List.

\begin{tabular}{|c|c|c|}
\hline Plain. & With Wheel. & $\begin{array}{l}\text { With Wheel and } \\
\text { Cutter or Joiner. }\end{array}$ \\
\hline $\begin{array}{r}\$ .5 .00 \\
6.50 \\
8.00\end{array}$ & $\begin{array}{r}\$ 7.50 \\
9.00\end{array}$ & \\
\hline 10.00 & 11.00 & $\$ 13.00$ \\
\hline 10.50 & 11.50 & 13.50 \\
\hline 11.00 & 12.00 & 14.00 \\
\hline 11.00 & 12.00 & 14.00 \\
\hline ...... & $\ldots \ldots \ldots$ & 15.00 \\
\hline
\end{tabular}

One extra point with each plow is included in the above prices.

On application will mail descriptive catalogue of the Oliver Plows.

Descriptice Circulars of aboz'e Plows mailed on applicution.

See Special Offers on third page of cover. 


\section{THE IMPROVED NORTH AMERICAN PLOW.}

\section{The Most Reliable Swivel Plow ever placed before the Public.}

The great variety of Swivel Plows on the market, all with more or less claim to perfection, often put the farmer in a serious dilemma as to which he should purchase. Every Swivel Plow has some points of merit, but we claim, and our claim is based upon the expressed opinions of nearly every experienced farmer in New England, to have the only perfect Swivel Plow ever invented. Many think this Plow is too highpriced, but taking into consideration its many advantages over others, and the various kinds of work that can be done with it, it is by far the cheapest of any in the market.

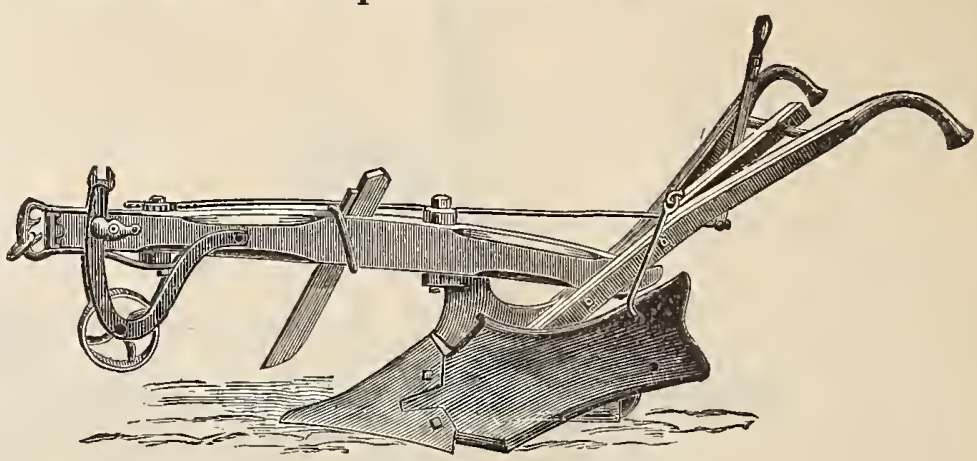

PRICE LIST OF THE IMPROVED NORTH AMERICAN PLOWS.

$$
\text { No. Description. }
$$

2. For sward or old land, two Horse, 3. For sward or old land, "

4. For one or two Horses

5. For light one-horse "Garden,"

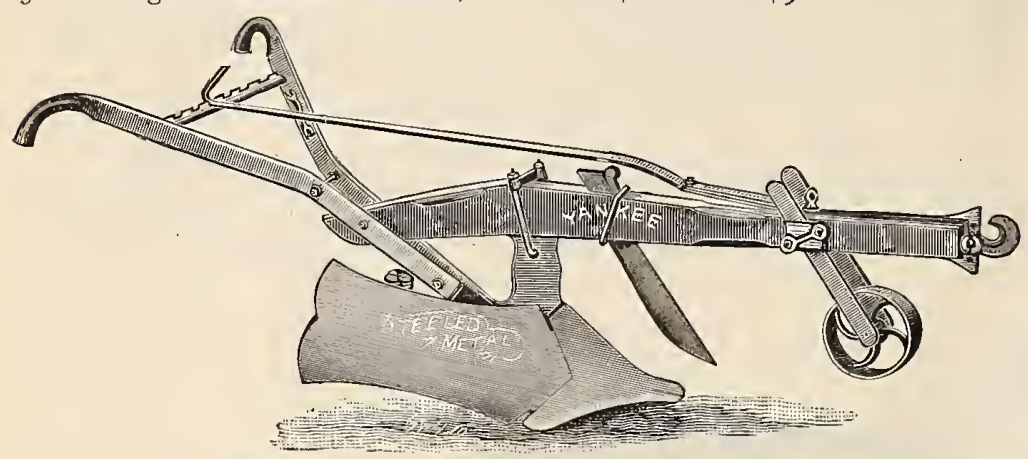

Vithout Stee
Manuf'r's J. B. \& Sons'

$\begin{array}{cc}\overline{-} & - \\ \$ 11.00 & \end{array}$
Without Steel
Cutter or Wheel.

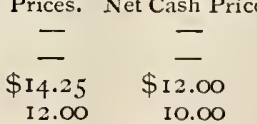

With Steel Cutter and Wheel.

\section{THE YANKEE SWIVEL PLOW.}

These plows are made from the Patent Steeled Metal, owned and controlled for the Eastern States solely by this company. It is not only harder than the chilled iron, being uniform throughout, but much less liable to breakage, while it scours readily in any soil.

\begin{tabular}{|c|c|c|c|c|c|c|c|c|c|c|c|}
\hline \multirow{2}{*}{$\begin{array}{l}\text { Num- } \\
\text { ber of } \\
\text { Plow. }\end{array}$} & \multicolumn{3}{|l|}{ PRICE LIST. } & \multicolumn{3}{|c|}{ Plain. } & \multicolumn{2}{|c|}{ With Wheel. } & & \multicolumn{2}{|c|}{$\begin{array}{l}\text { Wheel } \\
\text { and } \\
\text { Cutter. }\end{array}$} \\
\hline & \multicolumn{4}{|l|}{ Description. } & List. & $\frac{\text { Net. }}{\$ 700}$ & List. & Net. & et. & List. & Net. \\
\hline $\begin{array}{r}\text { OO } \\
\text { O } \\
1 \\
2 \\
3 \\
4\end{array}$ & \multicolumn{3}{|c|}{ 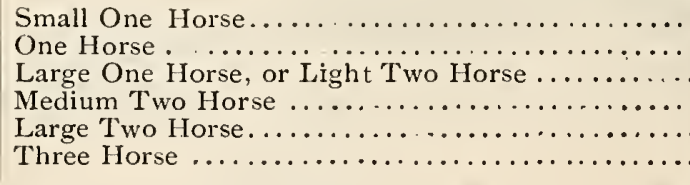 } & & $\begin{array}{ll}7 & 75 \\
8 & 00 \\
0 & 50 \\
2 & 00 \\
3 & 00 \\
5 & 50\end{array}$ & $\begin{array}{rl}\$ 7 & 00 \\
7 & 25 \\
9 & 50 \\
11 & 00 \\
12 & 00 \\
14 & 50\end{array}$ & $\begin{array}{rr}\$ 8 & 75 \\
9 & 00 \\
\text { I I } & 50 \\
\text { I } 3 & 00 \\
\text { I } 4 & 00 \\
\text { I6 } & 50\end{array}$ & $\begin{array}{r}\$ 8 \\
8 \\
10 \\
12 \\
13 \\
15\end{array}$ & $\begin{array}{l}\infty 0 \\
25 \\
50 \\
00 \\
00 \\
50\end{array}$ & $\begin{array}{l}1000 \\
300 \\
1450 \\
5 \\
50 \\
500\end{array}$ & $\begin{array}{ll}\$ 9 & 00 \\
12 & 00 \\
13 & 50 \\
14 & 50 \\
\text { I } 7 & 00\end{array}$ \\
\hline \multirow{2}{*}{$\begin{array}{l}\text { Num. } \\
\text { ber of } \\
\text { Plow. }\end{array}$} & \multirow{2}{*}{$\begin{array}{l}\text { Description. } \\
\text { New Series with Spring Foot Latch. }\end{array}$} & \multicolumn{2}{|c|}{ Plain. } & \multicolumn{2}{|c|}{ With Wheel. } & \multicolumn{2}{|c|}{$\begin{array}{l}\text { Wheel } \\
\text { and } \\
\text { Cutter. }\end{array}$} & \multicolumn{2}{|c|}{$\begin{array}{l}\text { Wheel } \\
\text { and } \\
\text { Jointer. }\end{array}$} & \multicolumn{2}{|c|}{$\begin{array}{l}\text { Wheel and } \\
\text { Rolling } \\
\text { Cutter. }\end{array}$} \\
\hline & & List. & Net. & List. & Net. & List. & Net. & List. & Net. & List. & Net. \\
\hline $\begin{array}{ll}\text { O } & \mathrm{H} \\
\mathrm{I} & \mathrm{H} \\
2 & \mathrm{H} \\
3 & \mathrm{H}\end{array}$ & 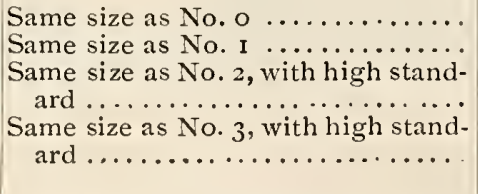 & $\begin{array}{ll}\$ 8 & 50 \\
\text { I I } & 00 \\
\text { I } 2 & 50 \\
\text { I } 3 & 50\end{array}$ & $\begin{array}{ll}\$ 7 & 50 \\
\text { IO } & 00 \\
& \\
\text { II } & 50 \\
\text { I } & 50\end{array}$ & $\begin{array}{ll}\$ 9 & 50 \\
\text { I } & 00 \\
\text { I3 } & 50 \\
\text { I4 } & 50\end{array}$ & $\begin{array}{ll}\$ 8 & 50 \\
\text { II } & 00 \\
\text { I } 2 & 50 \\
\text { I3 } & 50\end{array}$ & $\begin{array}{cc}\text { I0 } & 50 \\
13 & 50 \\
15 & 00 \\
16 & 00\end{array}$ & $\begin{array}{rl}\$ 9 & 50 \\
12 & 50 \\
14 & 00 \$ \\
15 & 00\end{array}$ & I6 50 & $\left\{\begin{array}{l}\$ 1400 \\
\text { I5 }\end{array}\right.$ & $\begin{array}{l}\$ 1600 \\
\text { I7 } 00\end{array}$ & $\left\{\begin{array}{l}1500 \\
1600\end{array}\right.$ \\
\hline
\end{tabular}




\section{O R G A N}

For Sod Land, Fall Seeding, and Stubble Ground.

Leaves no Furrows or Ridges. AGNXTS WAXTED.
SOMETHING ENTIRELY NEW. SPADING HARROW. Angle of Tceth adjustable to work at

Latest and Greatest Pulverizer in the World. Will do work no other can.

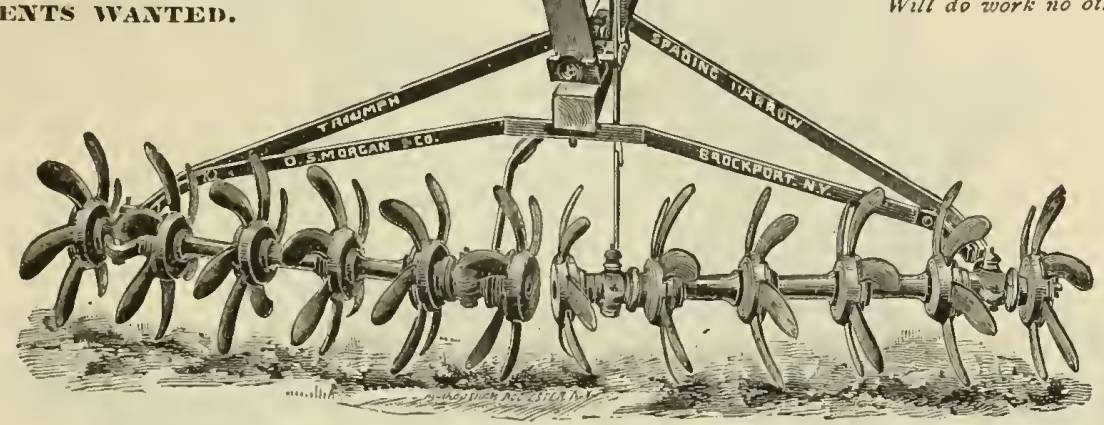

Fully Warranted and Sold on its

Merits.

\section{SIZE A, 2 GANGS - WORKS SOIL 6 FEET WIDE.}

NO HARROW IN THE WORLD EQUALS IT IN OPERATION.

From our experience with the Morgan Spading Harrow during this, its second season, we do not hesitate in saying that for an all-round greneral purpose Harrow, the "Morgan has no equal." The Harrow has been placed in the hands of the most competent men in New England, and their universal report is, "It is the best I have ever used." We are so certain of its merits, that to any reliable person wanting a Harrow, we will send the MIorgan on trial when requested to do so.

\section{J. Breck \& Sons' Net Cash Price List of Morgan Spading Harrows.}

Morgan Spading Harrow, Plain

Morgan Spading Harrow, with Evener, Whiffletrees, and Neck Yoke

Morgan Spading Harrow, with Evener, Whiflletrees, Neck Yoke, and Cleaners Descriptive Circulars and Testimonials mailed on Application.

$\$ 25.00$ $27 \cdot 50$ 30.00

\section{THE IMPROVED REVERSIBLE SMOOTHING HARROW.}

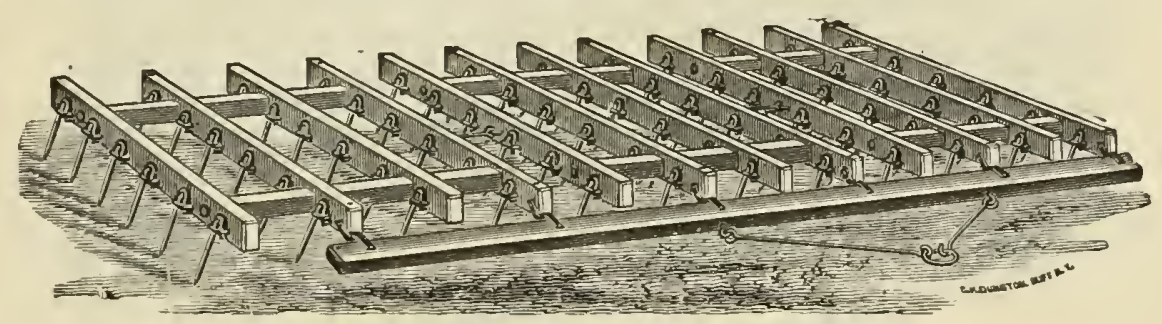

THE MOST ECONOMICAL HARROW

a farmer can possess, for while the common straight-tooth harrow is a tool that no tiller of the soil dispenses with, there are a large number of farmers who do not, as yet, fully understand the value of the Sinoothing Harrow, - not only for its efficiency in levelling and pulverizing the plowed land, but also for its immense laborsaving properties as a

\section{CULTIVATOR OF GROWING CROPS.}

The Smoothing Iarrow is known all over the United States as one of the greatest labor-saving implements in use. It will take the place of more farming tools than any other article manufactured, inasmuch as it is at once a pulverizer, a smoother or leveller, a cultivator, a horse-hoe, a broadcast weeder, a manure-spreader, and a seed-coverer.

A farmer can save a hundred dollars in hocing corn or potato crops alone, in one season, by its use. It will cultivate corn eight inches high, with inarked benefit.

The fundamental principle underlying its remarkable efficiency is THE DRAIV CLT or TuE SLANTING Тоотн, which distinguishes it from all of the old-fashioned harrows.

\section{PRICE LIST.}

Two section Smoothing Harrows, forty-eight $5 / 8$-inch steel teeth, 7 feet spread Three-section Smoothing Harrows, seventy-two $5 / 8$-inch steel teeth, 101/2 feet spread Seats, extra 


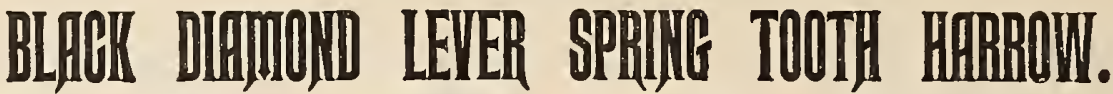

A Spring Tooth Harrow with a Quick and Easy Adjustment of Teeth by means of a lever, and retaining the only true shape and form.

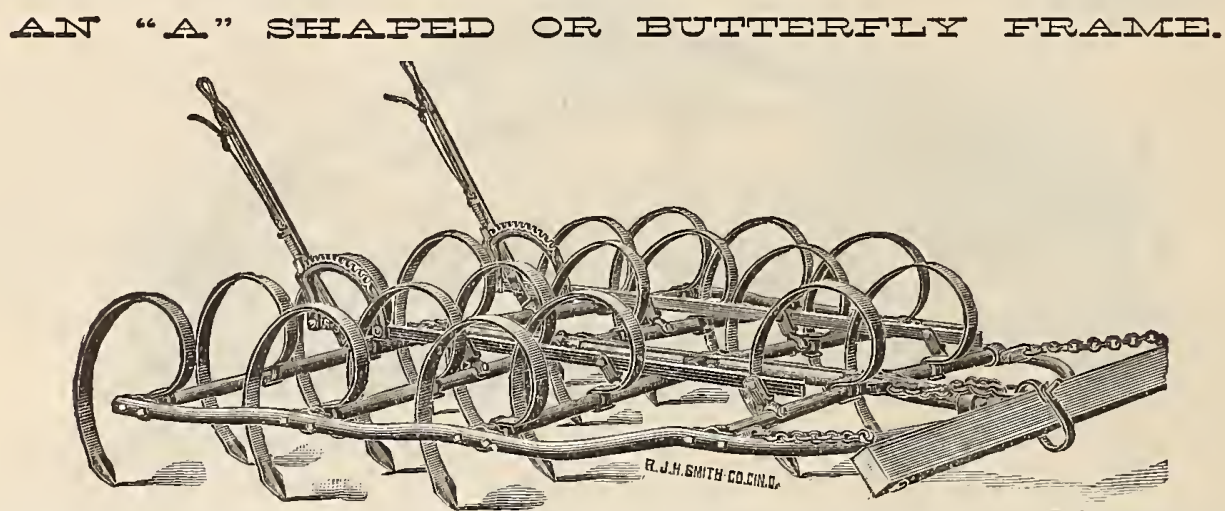

After careful experiment we have selected the BLACK DIAMOND LEVER SPRING TOOTH HARROW as the most perfect lever harrow known in the market. Having been thoroughly tested during two seasons we add it to our high grade implements as a companion to the Morgan Spading Harrow. In the Morgan Spading Harrow we have the best rotary karrow ever sold, as our constantly increasing sales testify, and in the Black Diamond Lever Spring Tooth Harrow the best floating or drag harrow. Every user of harrows needs one or the other - some need both.

: P R I C E LIS T:

\begin{tabular}{|c|c|c|}
\hline Toot & 66 & 86 \\
\hline s6 & 66 & ، \\
\hline 2 Tooth & Plain & Harrows \\
\hline "6 & 66 & "6 \\
\hline “6 & 66 & "6 \\
\hline
\end{tabular}

Descriptive Circulars mailed on application.

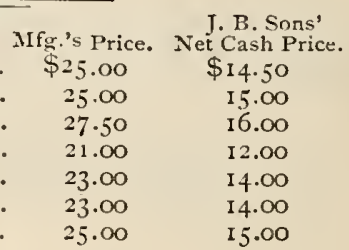

et Cash Price.

$\$ 14.50$

15.00

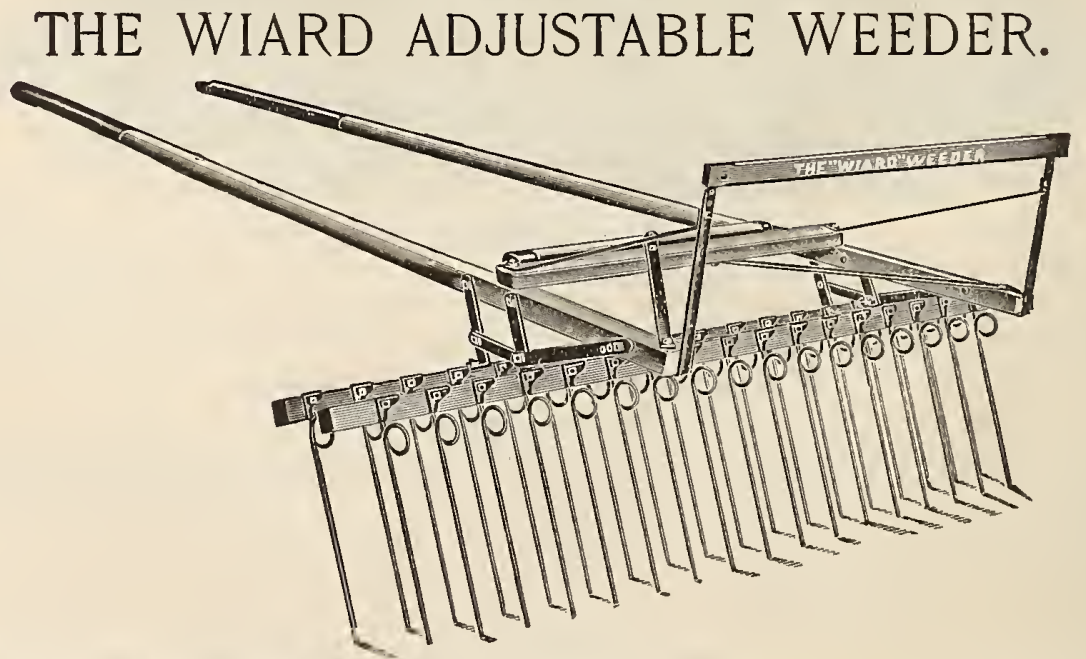

BY USING THIS WEEDER fields of corn, beans, potatoes, etc., can be kept clean of weeds without the labor and expense of the hoe and without damage to the plants. One trial will convince any farmer that he cannot afford to be without this implement.

J. Breck \& Sons' Net Cash Price, each

Descriptive Circular mailed on application.

$\$ 12.00$

See Special Offer on third page of cover. 
THE KING OF THE CORNFIELD COPN PLANTER.

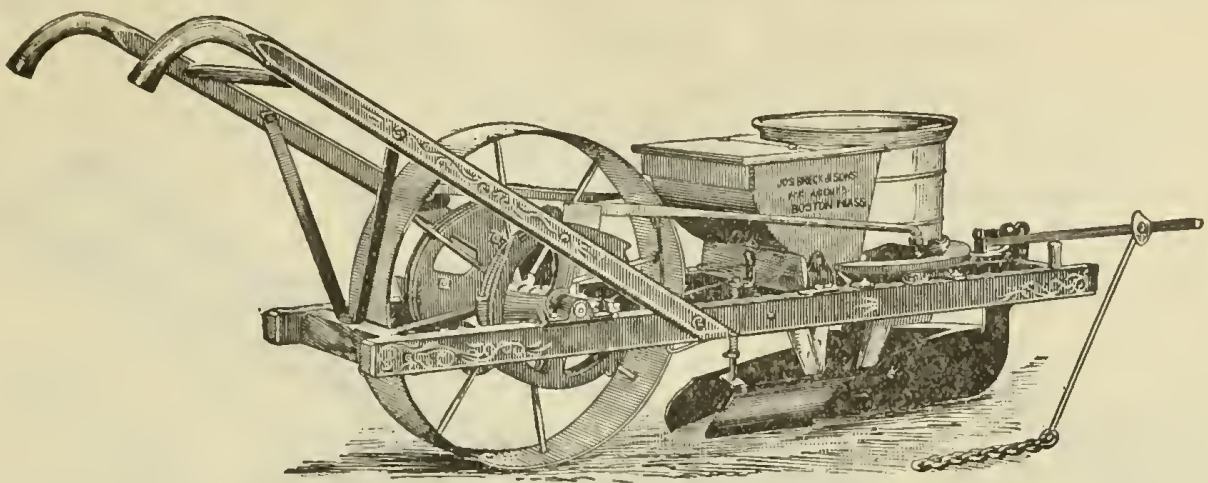

Superior to all others for planting Field, Ensilage 'and Fodder Corn, IBroom Corn, IBeans and Peas, nud other seeds of like size. Can also be aranged for dropping Beet secd.

One of the greatest of labor-saving implements is a reliable Corn Planter, and wlile many of the different makes offered have done failly good work, still none have met the requirements in many respects. WVe claim for the King of the Cornfield the highest degree of perfection yet attained, which, in combination with its extreme simplicity and durability, places it far altead of all competitors.

J. Breck \& Sons" Net Cash Price List.

24 -inch wheel plants $4 \% 9 \times 18 \times 36 \times 72$ inches apart

DESCIRPIVE PAMPIILTS MAILED ON APPLICATION.

\section{Strowbridge Broadcast Seed Sower.}

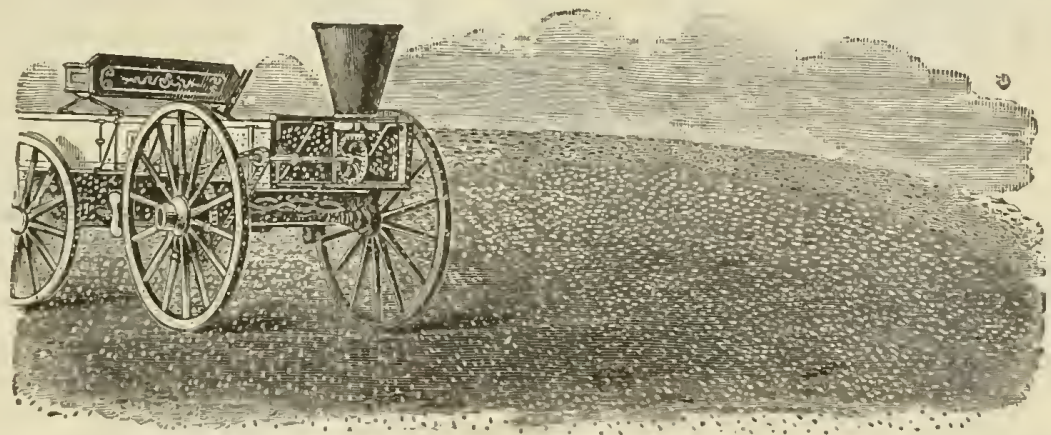

Sows all grain, grass seeds, plaster, salt, ashes, commercial fertilizers - everything requiring broadcasting - any quantity per acre, better and faster than any other method. Saves seed by sowing perfectly even. Not affected by wind, as seed is not thrown upwards. Sows half or full cast, on either or both sides of wagon. Readily attached to any wagon or cart without injury, and used wherever they can be driven. Lasts a lifetime. Sows So acres wheat per day.

Strowbridge Broadcast Seed Sowers . . . . . List Price, \$25.00. Net Price, \$r4.00.

\section{THOMPSON'S SEEDER.}

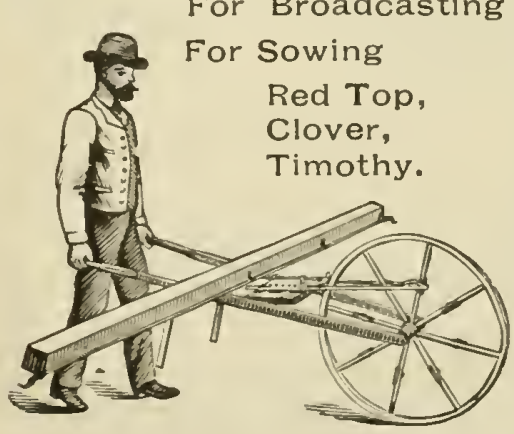

Thompson's Seeder.
Light, Strong, and Simple.

Sows uniformly the whole length of the hopper, twelve feet.

Its simplicity of construction and its accuracy of work in the field places it at the head of all seeders.

It has no Cam or Cog Gearing to get out of order.

It has a positive motion, and works as freely and easily when sowing as when empty.

Seeding is generally done at the time of year when winds preval ; it is then that the Seeder can be used with marked success.

No. I. Complete Clover and Grass Seeder . $\begin{array}{cc}\text { MIFR'. } & \text { J. B. SONS' } \\ \text { LIST PRICES. } & \text { NET PRICES. } \\ \$ 10.00 & \$ 9.00\end{array}$

No. 2. Complete Seeder, with double hopper for Grain and all kinds of grass seed

DESCRIPTIVE CIRCELARS MAILED ON APPLICATION. 


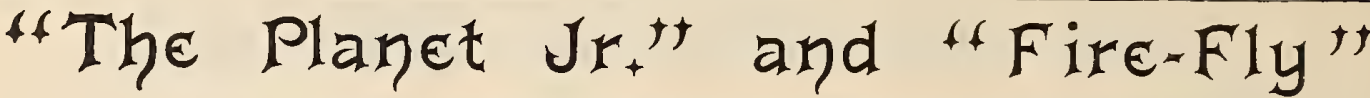

\section{FARM AND GARDEN IMPLEMENTS.}

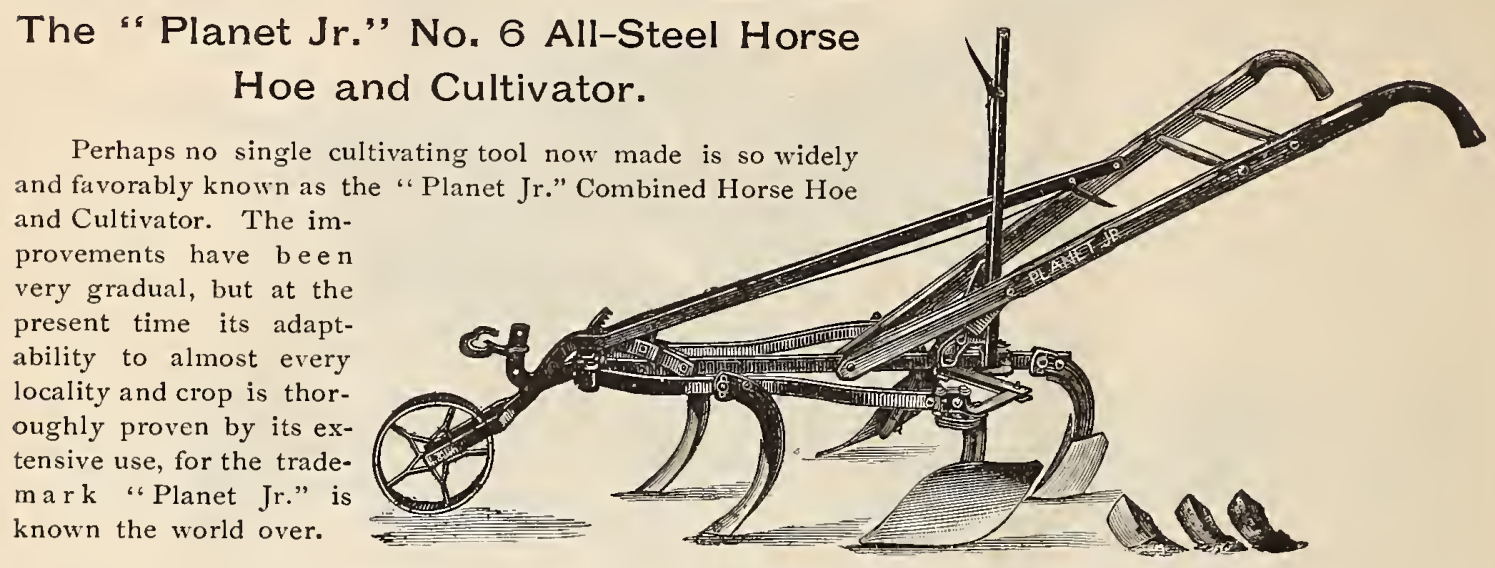

The "Planet Jr." Twelve-Tooth Harrow, Cultivator, and Pulverizer.

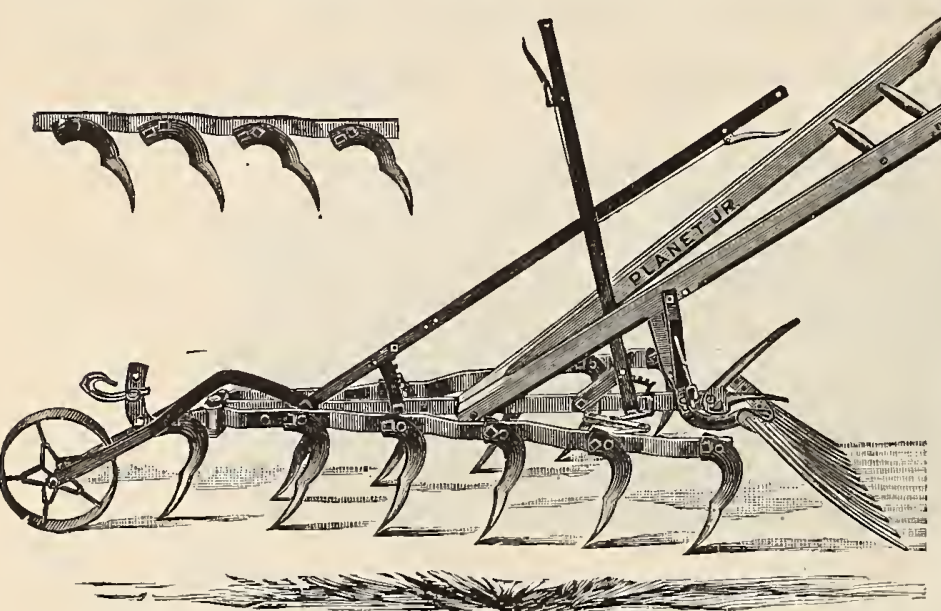

'This new tool is offered as the very best known for its intended purpose. The frame is high, and the blades are an inch wide, and of such perfect shape and symmetry as to work in the most thorough and satisfactory manner, and to offer an unusual amount of wearing surface. The recurred throat and high frame prevent clogging; the reverse posicion is given to the teeth in a short time by the changing of a single bolt in each. The frame is heavy and strong, and the teeth set straight with the line of motion at medium width, and are interchangeable.

PRICE LIST.

1894 Planet Jr. Horse Hoe, Complete 1894 Planet r. Horse Hoe, No Wheel 1890 Planet $1 \mathrm{r}$. Horse Hoe, Complete 1890 Planet Jr. Horse Hoe, No Wheel is89 Planet Jr. Horse Hoe, Complete
iss Planet Jr. Horse Hoe, No Wheel. IS 9 Planet yr. Horse Hoe, No Wheel
Market Gardener's Horse Hoe, Complete

Lever wheel, Complete

Old Style Wheel, Complete

Roller

Reversed Rake

Marking Attachment

Furrowing Steel, with wing

Furrowing Steel, no wings

Wings, each
Ridging Steels, each :

Pulverizer .

Vine Lifter Attachment

Nine-Tooth Horse Hoe Attachment

Deptl Regulators

Pres. Net Cash Prices.

\begin{tabular}{|c|c|c|c|c|c|c|c|c|c|c|c|c|}
\hline 2.00 & $\$ 9.00$ & \multicolumn{8}{|c|}{ 11-Tooth Harrow, Cultivator, and Pulverizer, } & \multicolumn{2}{|l|}{$\$ 12.00$} & $\$ 9.00$ \\
\hline 0.25 & 8.00 & Furrower, Iille & $r$, an & $\mathrm{d} \mathrm{Ri}$ & dger & & bin & & . & 16.00 & & 12.00 \\
\hline 11.25 & 8.50 & All.Steel Pulver & izer & and & Level & ler & & - & - & 11.00 & & S. 50 \\
\hline 10.25 & $7 \cdot 50$ & All.Steel Plain & Culti & vato & $\mathrm{r}, \mathrm{Co}$ & $m$ & ete & - & - & 8.00 & & 6.00 \\
\hline 10.25 & 8.00 & All-Steel Plain & Culti & vato & r, No & 16 & ieel & . & - & 7.00 & & 5.00 \\
\hline 9.25 & 7.00 & Planet $[r$. Doub] & le $\mathrm{Ce}$ & lery & Ifille & & - & . & . & 12.00 & & 10.00 \\
\hline 12.00 & 9.00 & Planet Jr. Single & $\mathrm{Cel}$ & ery 1 & Hiller & & - & • & - & 10.00 & & 9.00 \\
\hline - & $\$ 1.75$ & $1 \frac{1}{4}$ in & - & - & - & - & - & - & - & - & • & $\$ 0.12$ \\
\hline - & 1.00 & 13 in & - & . & . & - & - & - & - & - & • & .13 \\
\hline . & 2.00 & 2 inch Steels & - & - & . & - & • & - & - & - & - & .14 \\
\hline - & 1.00 & 3-inch 5 & - & - & - & - & - & - & - & - & - & - \\
\hline . & 2.00 & 4-inch S & & - & - & - & - & - & - & - & - & .17 \\
\hline - & 2.00 & 7-inch Shove St & eels & - & , & - & - & - & - & - & - & .40 \\
\hline - & 1.00 & S.inc & eels & - & . & - & - & - & . & - & - & .50 \\
\hline - & .50 & S-inch $\mathrm{S}$ & $\cdot$ & - & - & - & - & - & . & - & - & .35 \\
\hline - & $1.5^{0}$ & so-inch S & - & - & - & . & - & - & - & - & - & .4 \\
\hline - & 1.75 & 12-ing & . & . & - & • & . & - & - & • & • & .45 \\
\hline - & 1.75 & 15 -inc & & - & . & - & - & - & - & - & - & . 50 \\
\hline - & 1.75 & 6-incl & & - & - & - & - & - & - & • & - & • \\
\hline - & 5.00 & & & - & - & • & • & - & & • & & .65 \\
\hline - & $\cdot 5^{0}$ & Runner A & ient & & & . & - & - & - & - & & \\
\hline
\end{tabular}

ACP As our space is limited, we cannot give as full a description as we could wish to the Planet Jr. implements and their attachments. To all interested in the finest labor-saving tools ever invented, we would recommend sending for the complete Planet Jr. Catalogue, which we will mail to any address on application. for 


\section{PLANET JR. IMPLEMENTS FOR HAND USE. GREATLY IMPROVED FOR 1894.}

The Garden Tools, a description of which follows, are finely formed and finished tools, and to the practical inan they supply a need long felt; namely, a small implement to be used by hand, and at the same time perform its work with an accuracy that is only found in larger ma-

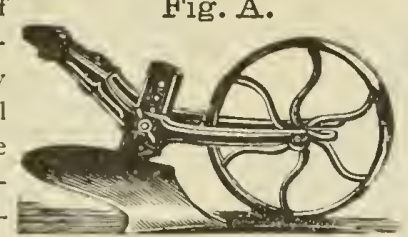

chines. Those having a kitchen garden and the market gardener will find their use invaluable. We want such men to know how useful the Planets are, and how nicely adapted to the work intended, and we feel sure that after careful examination of their merits they will not be without them.

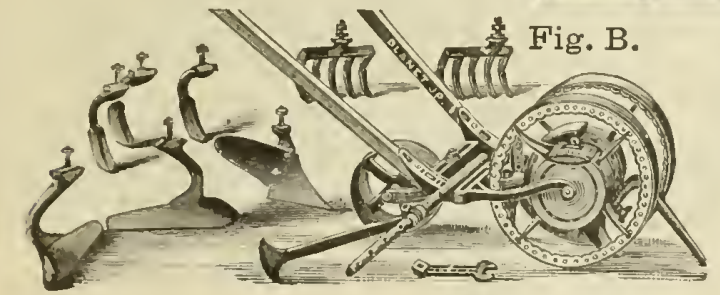

Fig. D.

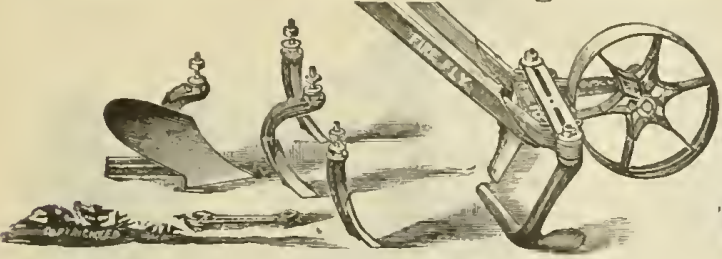

The Planet Jr. Combined

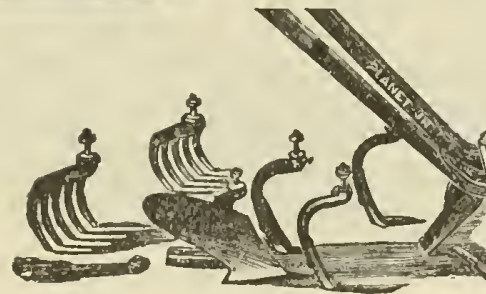

$2-12$

Fig. C.

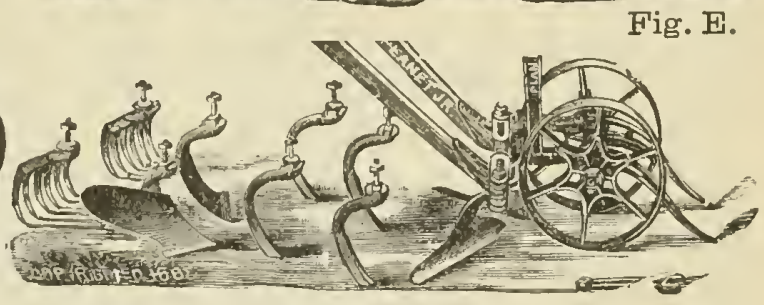

Fig. E.

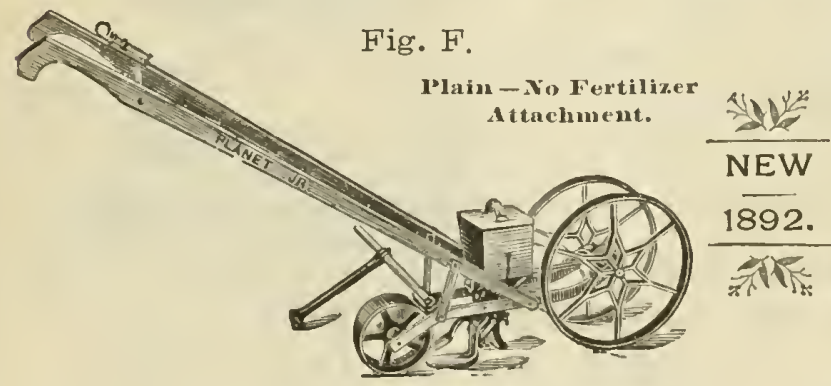

PRICE LIST.

The Planet Jr. Yo. Plain Drill, packed weicht 40 pounds

Fig. B. -The Plinet Jr. Combined Drill, lvheel IIne, Rake, and Plow, piacked weight 40 pounds Onion Sut Attachnent, fits either Drill

Fig. E.-Plinet Jr. Double IVheel IIne Cultivator, Rake, and Plow, 32 pounds $\ldots \ldots$ Fig. C. " " Fig. A.-The Fire-Fly lland Plow.

Fig. " " " Sinule Wheol Ilne Cultivator and Plow" 23

Fig. F. The Planet Jr. H HIl Dropping Drill

Fig. G.-The Planet Jr. Combined Ifill Dropping and Fertilizer Drill

\section{THE PLANET JR. GRASS EDGER.}

$\Lambda$ cheap, handy, and effective Grass Edger is a treasure, and here it is; one with which you can in an hour edge beautifully the walks and the Aower and shrub beds of an ordinary half-acre lawn. Think of it; why, in the usual way it would take a day. This perfect little tool does either

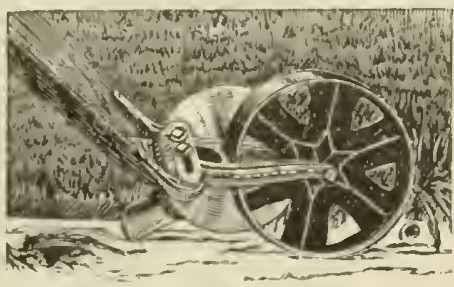

straight or curved work most accurately, edging at the desired angle, and at the speed of a mile an hour. It should be a constant companion of the mower, and is invaluable in giving the last touch of neatness to the lawn, when the mower has done its best.

Manufacturers' Price, Light, $\$ 4.00$; Heavy, $\$ 6.00$. J. B. \& Sons' Net Lash Price, Light, $\$ 3.75 ;$ Heavy, $\$ 5.50$.

We will mail on application, a large illustrated Catalogue, giring many valuable hints on the cultivation of the soil, and directions for the use of the Planet Jr. and Fire-Fly Tools.

See Special Offer on third page of usver. 


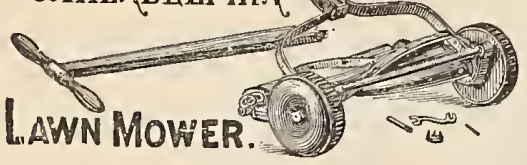

STYLE S, OPEN WIPER.

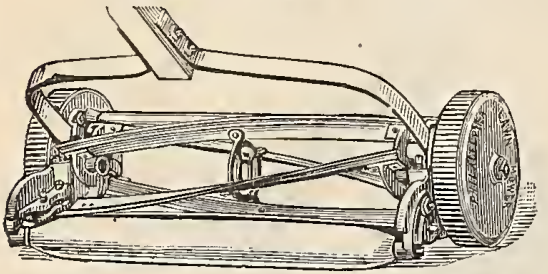

STYLE M, SOLID WIPER.

PESHILADELCPHIT

THE PHILADELPHIA LAWN MOWERS.

We take pleasure in again offering our customers, for the season of 1894 , the GENUINE PHILADELPHIA LAWN MOWERS.

That these machines are superior to all others is shown by the fact that nearly every Lawn Mower manufacturer is making mowers that imitate as closely as possible the Philadelphia. Genuine Philadelphia mowers have the name of the makers, "GRAHAM, EMLEN, and PASSMORE," cast on one wheel, and the words "PHILADELPHIA LAWN MOWERS" cast on the other. Any machines not having drive wheels lettered as above are inferior imitations, and are not desirable at any price.

Style " M" machines are recommended for general purposes, and we warrant them to run easier, to be more durable, and to cut as high grass as any lawn mower made, no matter how big a wheel it has.

Style "D" machines are recommended for small grass plots, and for lawns of less than one-eighth of an acre.

Style "S" machines are recommended to all desiring to purchase an open wiper lawn mower. They run quietly, and weigh much less than other lawn mowers.

HAND LAWN MOWERS.

Style.

Style.
D, Solid Wiper Width of Cut
D, Open or Solid Wiper $\quad$ 10-inch
I 2 "“

D

D, I4 " 14

M, Solid Wiper

$\mathrm{M}$,

M,

$\mathrm{M}$, " " "

S, Open Wiper

$S$, " " "

$\mathrm{S}$, “

A, “

A, “

STYLE A, OPEN WIPER

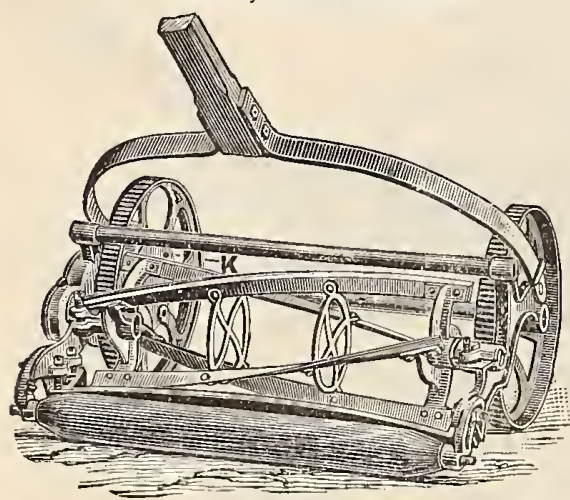

STYLE D, OPEN WIPER.

\begin{tabular}{|c|c|c|}
\hline & Mfs'. & Net Cash \\
\hline $\begin{array}{l}\text { Weight. } \\
26 \text { lbs. }\end{array}$ & $\begin{array}{l}\text { Price. } \\
\$ 13.00\end{array}$ & $\begin{array}{l}\text { Price. } \\
\$ 5.00\end{array}$ \\
\hline & 15.00 & \\
\hline $30 ،$ & I 7.00 & 7.00 \\
\hline 36 ، & 17.00 & 7.00 \\
\hline $3^{8}$ " & $\therefore 9.00$ & 0.0 \\
\hline$"$ " & 21.00 & 9.00 \\
\hline $16 ،$ & 23.00 & 10.00 \\
\hline 33 " & 17.00 & 7.00 \\
\hline & 19.00 & 8.06 \\
\hline 6 & 21.0 & 9.00 \\
\hline “" & 28.00 & 14.00 \\
\hline 4 “" & 31.00 & 15.0 \\
\hline
\end{tabular}

HORSE LAWN MOWERS.

30-inch, with Draft Rod, 3I5 lbs. . . . . \$100.00 \$80.00 30 " " "Shaft and Seat, 350 lbs. . . $120.00 \quad 95.00$ 36 " " " " 450 lbs. . . 160.00145 .00

Style A Machines are made with Driving Wheels 10 inches diam. Wiper, 6 1-2 inches diam.

Malleable Steel Wheels and Frame. Best Possible Construction. High Wheels - Large Wiper.

\section{LESS WEIGHT}

Than the ordinary Low Wheel Mowers. Noiseless.

Do not buy a Lawn Mower until you examine this Machine.

\section{THE PHILADELPHIA HORSE LAWN MOWERS.}

To those who are the fortunate possessors of lawns so large that the use of a hand mower would become tedious, we offer the Philadelphia Horse Lawn Mower, feeling confident that it will do its work in a thorough manner, with a great saving of time and labor. As shown with shafts and seat, it is intended to be used on large open grounds. When used with draft rod, it is especially adapted to hilly and uneven lawns where there are many walks and much shrubbery.

The 36-inch cut Horse Lawn Mower is intended for parks and open grounds, and is constructed in the most thorough manner with steel shafting, brass bushing, etc., and must be examined to be appreciated.

Descriptive Circulars and Price Lists of the 3O-INCH HORSE LAWN MOWER. Pion.

See Special Offers on third page of cover. 


\section{BAY STATE, EASY, AND HARVARD LAWN MOWERS.}

Of the agencies formerly held by Messrs. Parker \& Wood, we have retained, among others, the sale of the "Bay State," "Easy," and " Harvard" Lawn Mowers for New England, and take pleasure in recommending them to our custoners. The "Bay State" has many, friends and is first-class in every respect. Tlie "Easy" is the only mower made capable of doing perfect work on borders and terraces. The "Harvard" is an excellent machine, at a low price, and is fully warranted.

\section{BAY STATE LAWN MOWER.}

This mower has been on the market so many years it has a reputation second to none, and in open competition has been pronounced the best by gardeners and others competent to judge. It has open wiper knives; that they are the best is proven by the manufacturers of solid wiper mowers now making an open wiper machine to meet the growing demand. Easy running and almost noiseless. Fully warranted in every respect.

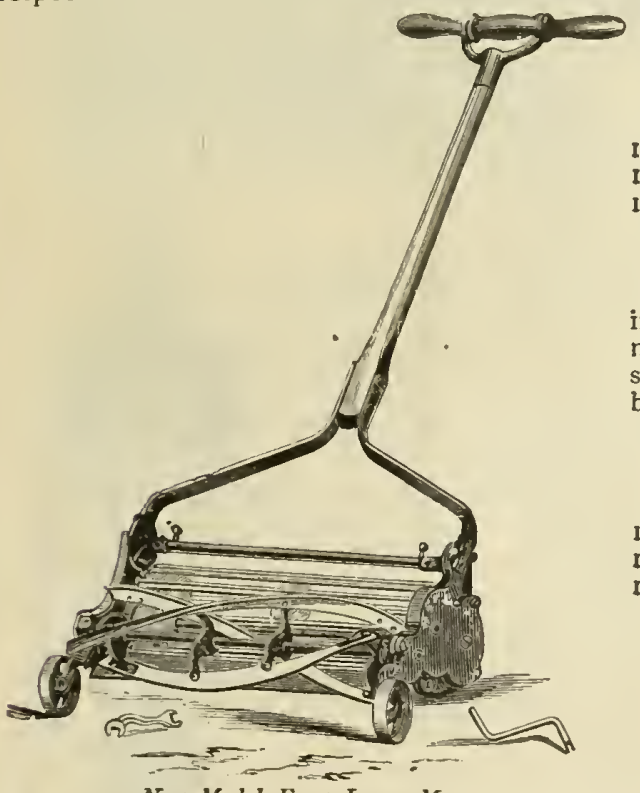

New Model Easy Lazun Mozver.

To supply the demand for a low-priced lawn mower, we have had the Harvard manufactured expressly for us. It is by no means a cheap-made mower, as so many of the low priced machines are.

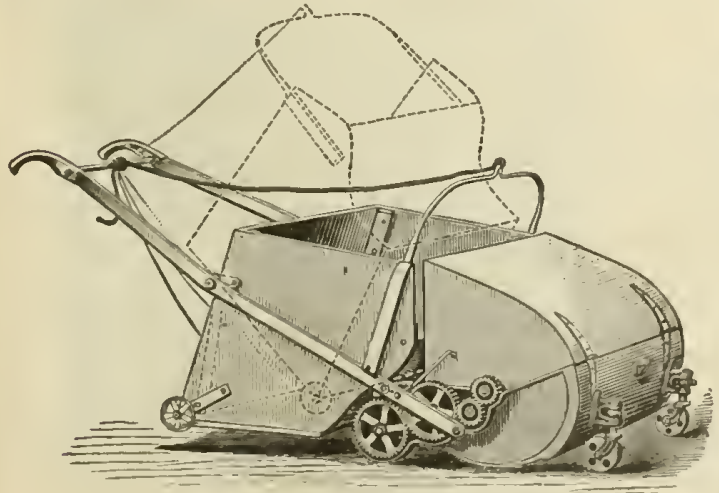

The Lazm Mower's Partner.

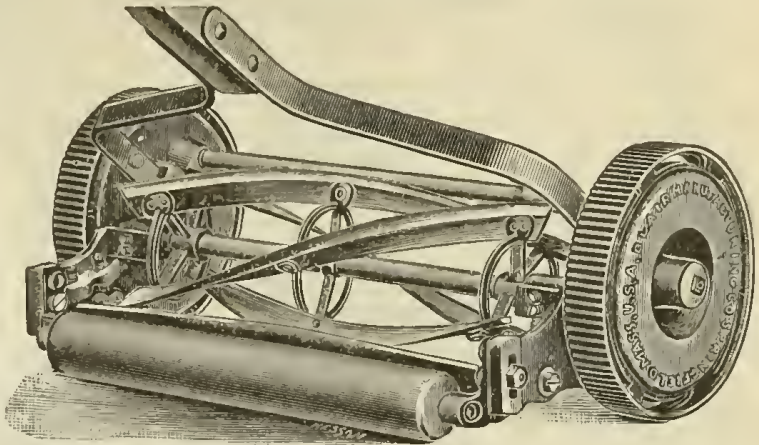

Bay State Lazn Mower.

PIRICE LIST.

\begin{tabular}{|c|c|c|c|c|c|}
\hline $\begin{array}{l}\text { MFRs' } \\
\text { LIST. } \\
\text { Prices. } \\
\text { pI3.00 }\end{array}$ & $\begin{array}{l}\text { J.B.S. } \\
\text { NET CASH. } \\
\text { Prices. } \\
\$ 5.00\end{array}$ & 16-inch & cut, & $\begin{array}{c}\text { MFRS, } \\
\text { LIST. } \\
\text { Prices. } \\
\$ \text { I } 9.00\end{array}$ & $\begin{array}{l}\text { J. B.S. } \\
\text { NET CASH. } \\
\text { Prices. } \\
\$ 8.00\end{array}$ \\
\hline 15.00 & 6.00 & 186 & 66 & 21.00 & 9.00 \\
\hline 17.00 & 7.00 & 20 & 66 & 23.00 & 10.00 \\
\hline
\end{tabular}

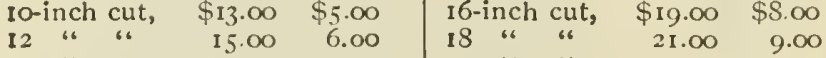

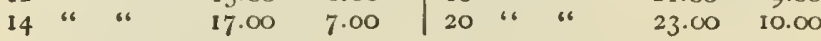

\section{NEW MODEL EASY LAWN MOWER.}

It is perfectly noiseless. Constructed of steel and malleable iron, runs only on the cut portion of the lawn, consequently does not leave it streaked as many do. It will cut nearer to fences, shrubs, and trees, and is the only mower that will perfectly cut borders and terraces. Every mower warranted perfect.

\begin{tabular}{|c|c|c|c|c|c|}
\hline \multirow[b]{3}{*}{ 10-inch cut, } & \multicolumn{3}{|c|}{ PRICE LIST. } & \multirow{3}{*}{$\begin{array}{l}\text { M'Frs } \\
\text { L1ST. } \\
\text { Prices. } \\
\$ 19.00\end{array}$} & \multirow{3}{*}{$\begin{array}{c}\text { J. B.S. } \\
\text { NET CASH } \\
\text { Prices. } \\
\$ 8.00\end{array}$} \\
\hline & $\begin{array}{l}\text { MFRS' } \\
\text { LIST. } \\
\text { Prices. }\end{array}$ & $\begin{array}{l}\text { J. B.S. } \\
\text { NET CASH. } \\
\text { Prices. }\end{array}$ & & & \\
\hline & $\$ 13.00$ & $\$ 5.00$ & I6-inch cut, & & \\
\hline & 15.00 & 6.00 & 18 “ “ & 21.00 & 9.00 \\
\hline "6 & 17.00 & 7.00 & 20 & 23.00 & 10.00 \\
\hline
\end{tabular}

THE HARVARD LAWN MOWER.

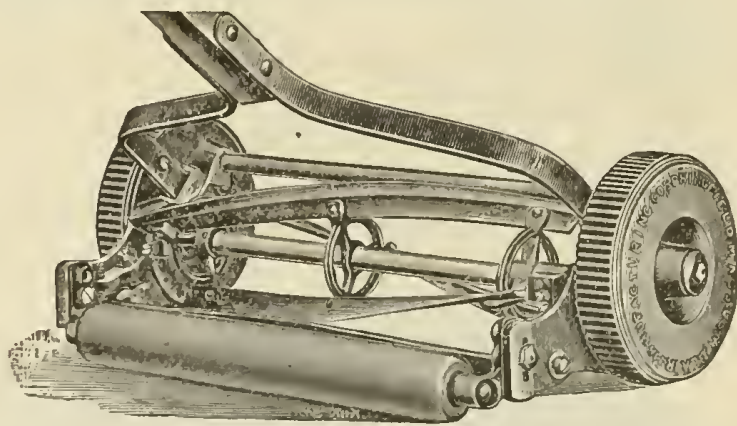

The Harvard Lawn Mozwer. MFRS' LIST PRICE. J. B. \& S. NET CASH. 12-inch Harvard Lawn Mower, \$15.00 \$4.00

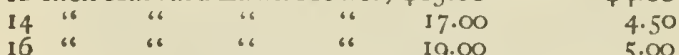
LAWN MOWER'S PARTNER, OR CUT GRASS COLLECTOR.

ReCeIVEd TIE IIIGHEST AND ONLY AWARd AT THE WORLD's Fark, Chicago.

The Lawn Mower's Partner is adjustable to all sizes and makes of mowers. It was the only Grass Carrier used on the World's Fair lawns. Why? Because it is the only practicable grass carrier made, and all the other makers were afraid to expose their carriers on the World's Fair lawns before the public, as they knew it would not be to their advantage. Mfrs' prices, \$2.50 each; J. B. S Sons' net price, \$2.25 each.

25e Descriptive circular of the above Lawn Moners mailed on rpplication. See Special Offers on third page of cover. 


\section{HORSE HAY FORKS AND CARRIERS.}

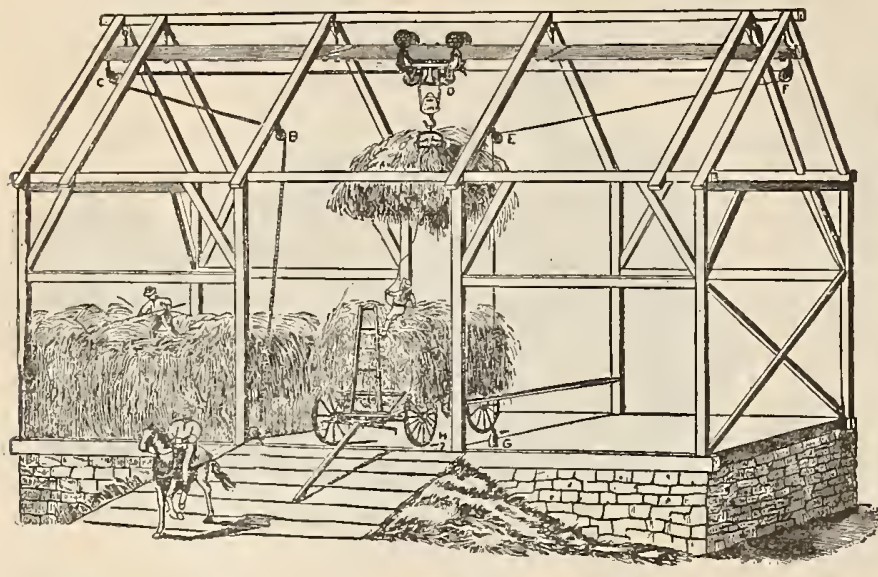

This cut shows the arrangement of a system of putting hay into a barn by horse power, doing it at less cost and more expeditiously than in the old-fashioned way. The prices given below for fitting up different sized barns with the most improved machinery for unloading and storing hay are not exact figures, but are approximate, and can be varied according to the quality of material and style of fork used. Believing, however, that "the best is the clieapest," we recommend using a solid steel track, reversible carrier, grappling fork, best quality pulleys, and good manilla rope.

For fitting up a 40-foot Barn, about . \$30.00 For fitting up a 60 -foot Barn, about . 35.00 For fitting up a roo-foot Barn, about . 45.00

Estimates furnished on application. In inquiring for prices, please state length of barn, number of rafters, height from floor to ridgepole, and send rough sketch of barn showing location of doors and bays.

Descriptive circulars mailed free.

\section{SURE GRIP STEEL TACKLE BLOCK.}

Will hold load at any point without fastening the rope. The heavier the load, the better the grip. Never gets out of order. There is no back slip. Accidents are avoided. Blocks are inade of steel.

No. 3. To be used with $3 / 8$-inch rope.

One man can lift . .

No 4. To be used with $1 / 2$-inch rope.

One man can lift Capacity

No. 5. To be used with $5 / 8$-inch rope. One man can lift

Capacity .

No. 6. To be used with $3 / 4$-inch rope. One man can lift Capacity

No. $41 / 2$. To be used with $1 / 2$-inch rope. One man can lift Capacity.

No. 51/2. To be used with $5 / 8$-inch rope. One man can lift Capacity No. $61 / 2$. To be used with $3 / 4$-inch rope. Capacity .

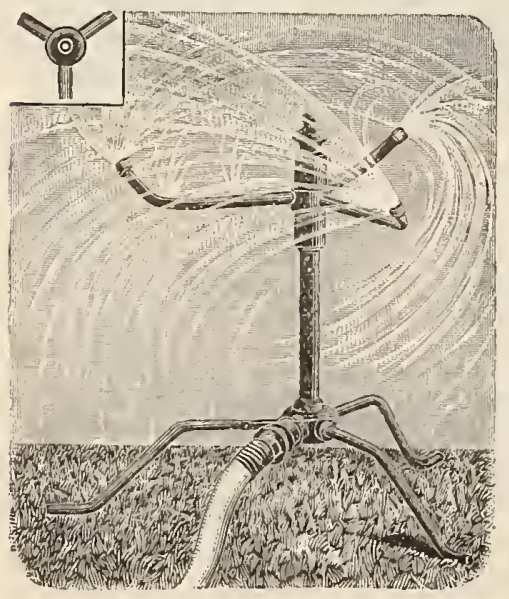

\section{"SAN FRANCISCO" LAWN SPRINKLER.}

Until arrangements are perfected with the elements by our wouldbe rain producers, so that showers can be produced at will, we shall, in the future as in the past, depend on artificial irrigation. For this purpose the San Francisco Sprinkler has been devised. Its points of particular merit are, all the working parts being inade of gun metal, in place of lead or cast iron, steady and continuous water pressure in the revolving portions, consequently greater quantity and more even deposit of water on the lawn, an instantaneous adjustment to take up wear for all time. It is so constructed that it may be pulled by the hose from one part of the lawn to another, thus avoiding the necessity of wetting the feet.

\section{PTRICE LIST.}

Manufacturers' price, \$2.00. Joseph Breck \& Sons' net price, \$I.50. 


\section{STABLE FITTINGS.}

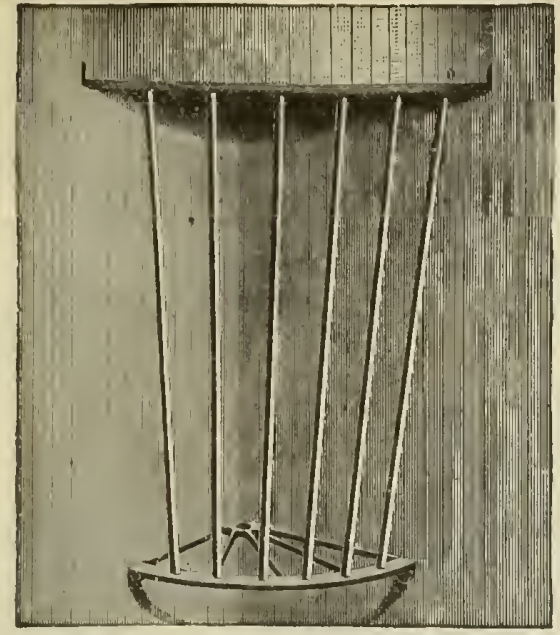

WROUGHT IRON CORNER RACK.

Net price, each . . . . \$I.75

\section{BLANKET BRACKETS.}

\section{5-inch Projection, Japanned Iron, per} pair 5-inch Projection, Brass, per pair $\quad 2.50$

READ'S HARNESS BRACKETS.

Net price, each . . . . . \$1.75

\section{SPONGE BOX.}

Net Prices.

No. 1. 9:14 inches, Cast Iron, each \$1.00

No. 2. $7 \times 10$ inches, Galvanized

Wire, each . . . . . . . . 55

STALL COLLAR.

Length, 35 inches; width, 22 inches.

Cast Iron. Net price, each . • \$1.25

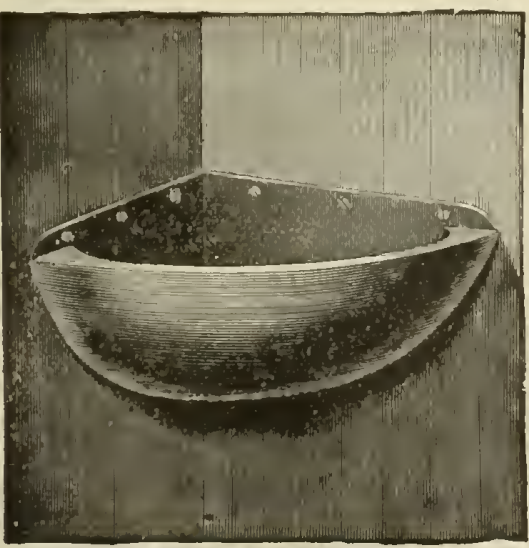

CORNER MANGER.

No. $01 \frac{1}{2}$. I $4 \frac{1}{2} \times \mathrm{xS}$, each

No. 3. I $7 \times 10$, each .
We carry in stock a full line of Stable fittings and supplies, a few only being shown or mentioned here as our space is very limited. We invite cor. respondence or a personal call at our warerooms, to those intending to build or refit a stable, and feel, taking into consideration the quality of our goods and low prices, that we can give satisfaction.

Will mail on application our large catalogue, covering the complete line of Stable Fittings and Supplies.

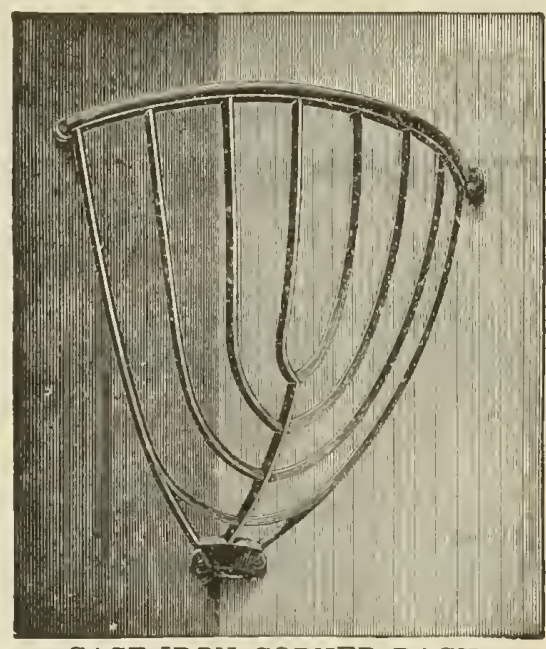

CAST IRON CORNER RACK.

Net price . . . . . \$I.75

\section{SALT DISH.}

Net Prices.

No. I. $6 \times 8$ inches, Cast Iron, each $\$ 0.60$ .80

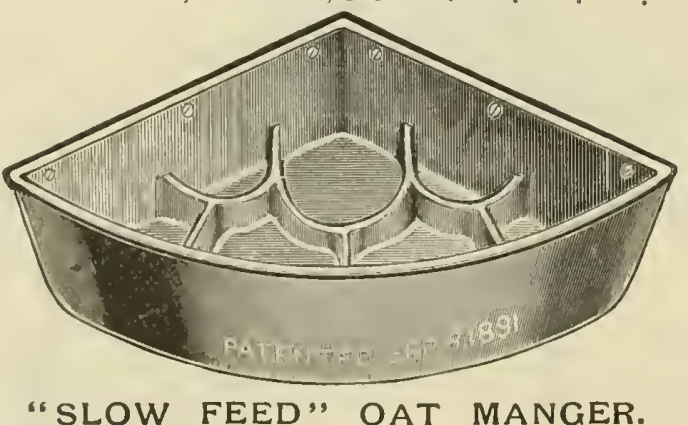

Since ISSr we have sold Iron Mangers of various patterns, but no Feed Boxes, Hay Racks, Patent Overhead Hitches, etc. have ever called out so many letters and words of approval as the "Slow Feed" Manger. It has Seren Small Cells or Pockets, from which the grain cannot be poked, and which prevent a greedy

hore 2 eating the grain too fast.
Weight, 25 lbs. Capacity, 15 quarts. Size, $17 \times 17 \times 6$ deep.

1.75 Each cell in the manger holds one pint. Net price, $\$ 1.60$. See Special Offers on inird page of cover. 


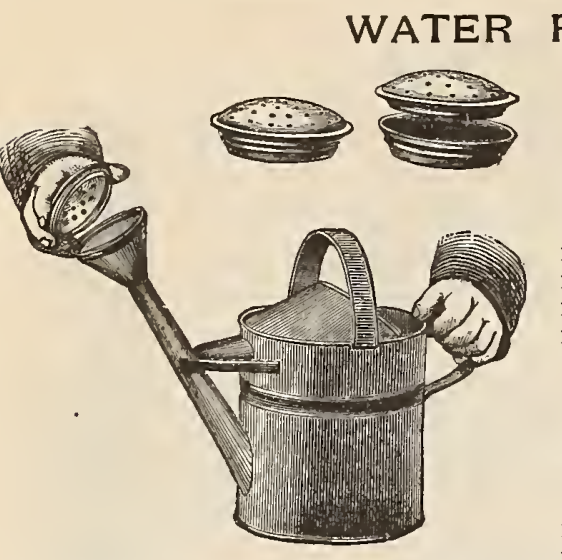

POTS OR SPRINKLERS.

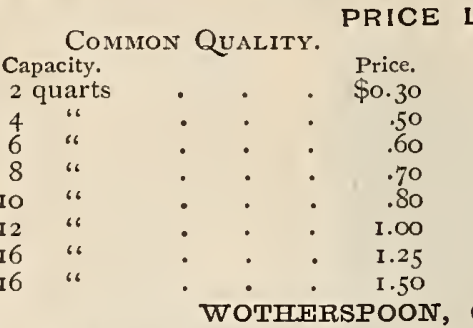

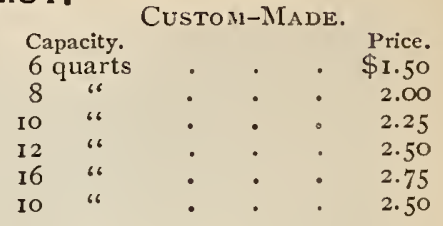

VICTOR SPRAY AND FORCE PUMP.

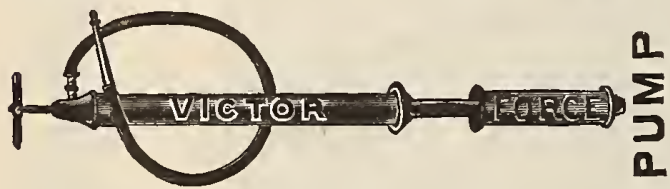

The Victor Force Pumps are made on scientific principles, and have no ancient or moss-backed ideas about them. See them work and you will be convinced that all other pumps of this class are doomed to be remembered in future as relics of the past.

Net cash price, $\$ 3.50$ each.

\section{WATVANIZED.}

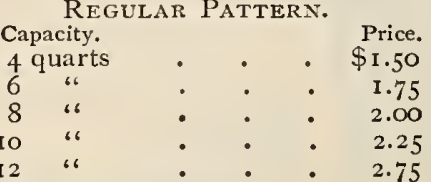

French Pattern.

\begin{tabular}{|c|c|c|c|}
\hline \multirow{2}{*}{\multicolumn{4}{|c|}{ Capacity. }} \\
\hline & & & \\
\hline \multicolumn{2}{|c|}{$\begin{array}{l}\text { Capacity. } \\
4 \text { quarts }\end{array}$} & - & $\$ 1.75$ \\
\hline 6 & - & - & 2.00 \\
\hline 66 & - & - & 2.25 \\
\hline “ & . & . & 2.50 \\
\hline "6 & . & . & 3.00 \\
\hline
\end{tabular}

\section{HOSE REELS.}

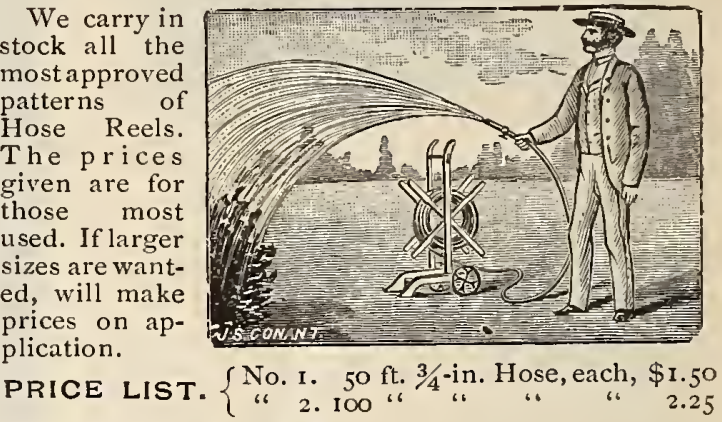

\section{RUBBER AND COTTON HOSE.}

There is no article sold that is more apt to deceive the purchaser than Garden Hose; therefore it is important to buy only of reliable houses. We make as pecialty of selling only those grades of Hose that are adapted to the different water pressures throughout the country. We use every endeavor to have the best quality of Hose only, manufactured for us, and warrant the qualities named below. Please give water pressure when ordering.

\section{PRICE LIST. (Prices include Couplings.)} RUBBER HOSE.

Superior $3 / 4$-inch, 3-ply, suitable for the heaviest pressure, per foot B. B. Co., $3 / 4$-inch, 3 -ply B. B. Co., $1 / 2$-inch, 3-ply, Extra, 3/4-inch, 3-ply, Extra, 1/2-inch, 3-ply,

$\begin{array}{lll}\text { " " } & \text { " } & \text { heavy } \\ \text { " } & \text { " } & \text { ordinary } \\ & & \text { ordinary }\end{array}$
COTTON HOSE.

Cotton, $3 / 4$-inch, suitable for all pressures, per foot Cotton, $1 / 2$-inch,

\section{LAWN SPRINKLERS.}

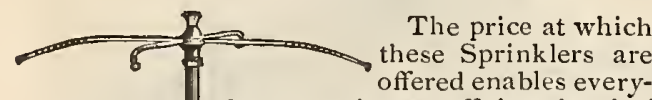
body, having a sufficient head of water, to have a beautiful fountain on the lawn, which not only pleases the sight but is beneficial to the grass. Every Sprinkler warranted.
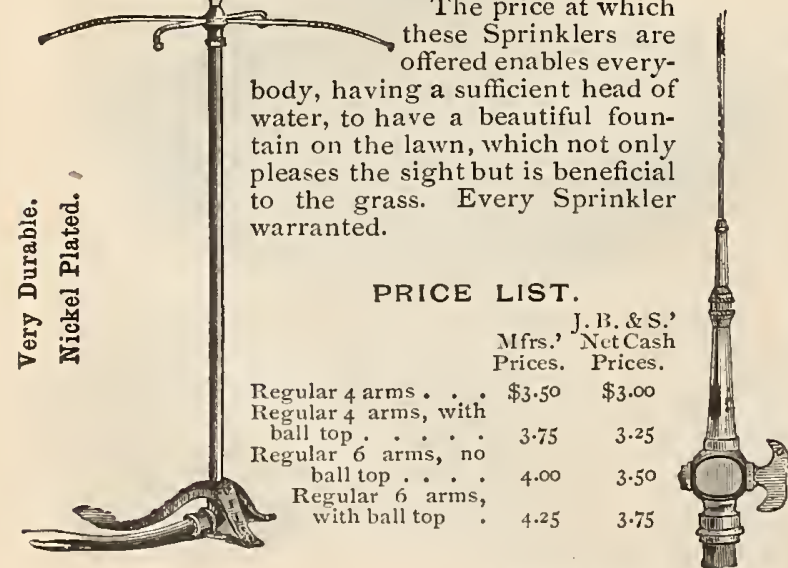

A combination spray and stream nozzle.

Net Price, 65 c. By mail, 75 c.

$$
\text { Gem, 3/4-inch. }
$$

A graduating nozzle, throwing water from a fine mist to a coarse stream.

Net Price, 65 c. By mail, $75 \mathrm{c}$.

Lowell, 3/4-inch.

Similar to the Gem, producing the same effects.

Net Price, 65c. By mail, 75 c.

The "Boss," $3 / 4$-inch.

The best nozzle for Flower Beds. Throws a flat spray or straight stream. Net Price, 65c. By mail, $75 \mathrm{c}$.

Brass Hose Pipe, 3/4-inch. Has detachable tip and rose.

Net Price, $\$$ r.00. By mail, $\$$ r.r.15.

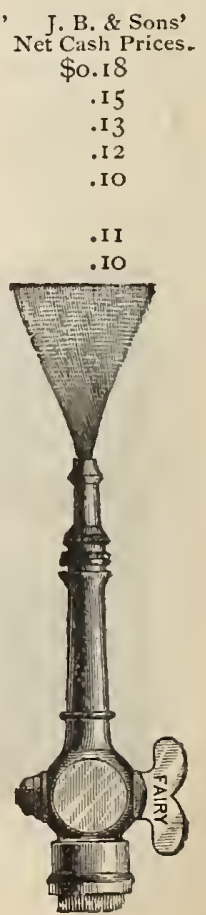


WHEELBARROWS.

PRICE LIST.

No. 2. No. 4 .

BRECK CUSTOM.

$\$ 5.50$

CHALLENGE.

4.00

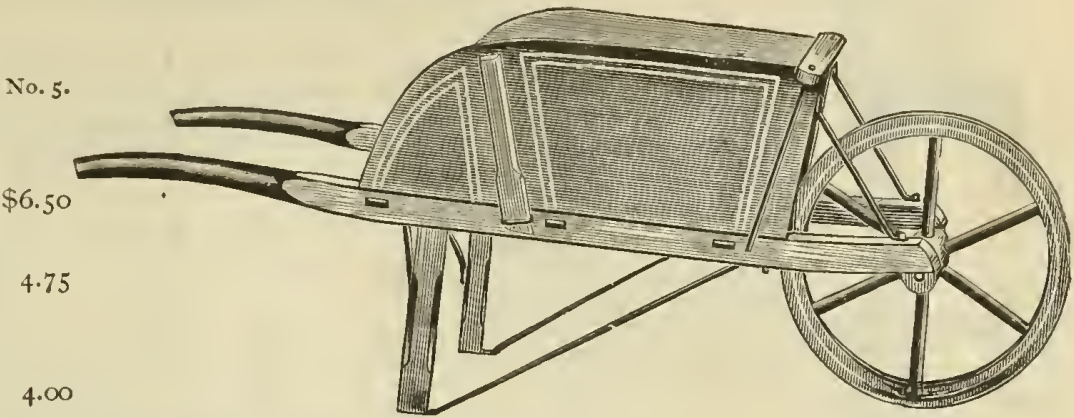

EUREKA.

$\$ 3.25$

$3 \cdot 50$

\section{WATER-BARREL TRUCK.}

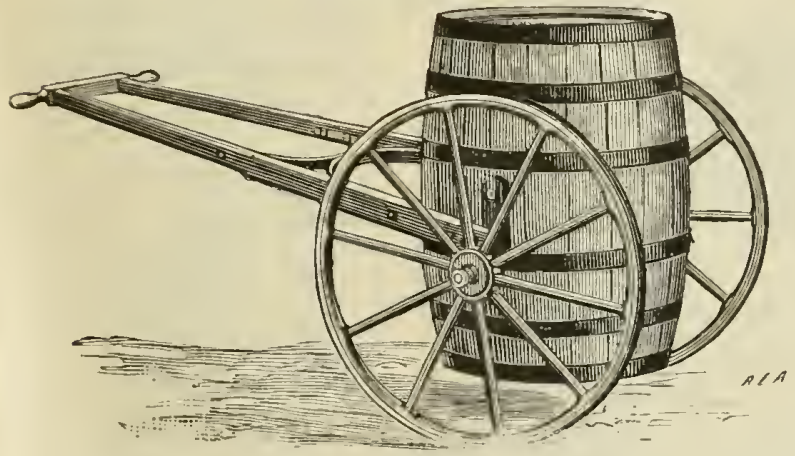

The Water-Barrel Truck is designed for carrying water to the garden or lawn, and will be found of great service during the hot summer months. By its use the flower garden and lawn can be kept well watered with an expenditure of very little time and labor, and instead of the lawn or garden becoming burned and dried up by the scorching sun, the few minutes spent in the morning or evening watering will be amply repaid by the fresh and beautiful appearance of both flowers and grass. Considering the innumerable purposes for which this truck is adapted, it becomes indispensable after once using. The barrel can be raised from the ground, carried to the place desired, and instantly detached, all without handling. $\$ 8.00$ net.

PRICE LIST. Truck complete with Barrel,

\section{GARDEN ROLLERS.}

This implement is very valuable for use in the garden, on the lawn, and around the house. With it the lawn can be nicely rolled, removing all the small stones, and the walks kept nicely smoothed. Being made of iron, it does not clog as easily as a stone roller.

Since the Hand Roller was first introduced it has been greatly improved in style and variety of forms, and by the addition of weights along the shaft, as shown in the cut, greater weight is obtained, while they are so adjusted that when not in use the handle is thrown up from the ground, and kept clean and out of the way.

\section{PRICE LIST.}

Description.

IIanufacturers' J. Breck \& Sons'

\begin{tabular}{|c|c|c|c|c|c|c|c|c|c|c|}
\hline sec & $71 / 2$ in & face & , 15 in & - dia., & th weigh & iDout & 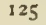 & $10 \mathrm{~s}$ & $\$ 5.00$ & $\$ 7.00$ \\
\hline a6 & 20 & $"$ & 20 & $"$ & " & $"$ & 220 & $"$ & 14.00 & \\
\hline " & 12 & " & 20 & “ & " & " & 300 & "“ & 19.00 & 16.00 \\
\hline “ & 12 & " & 24 & “ & " & “ & 400 & " & 22.00 & 20.00 \\
\hline & 12 & $"$ & $2 S$ & " & “ & “ & 500 & " & 26.00 & 23. \\
\hline
\end{tabular}

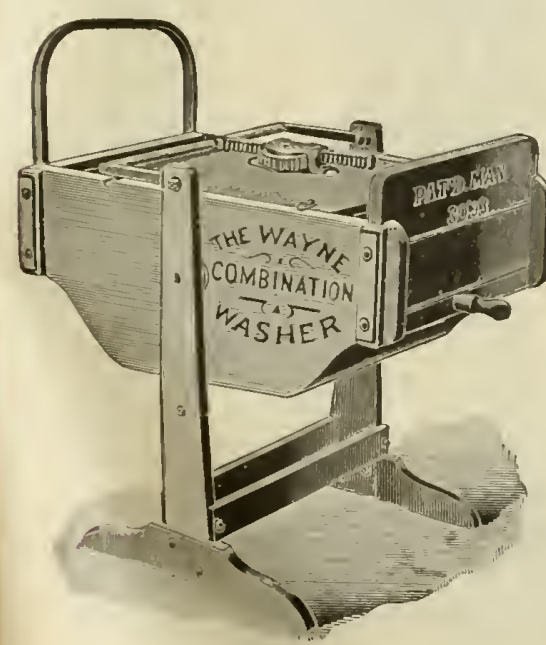

\section{THE \\ WAYNE \\ COMBINATION}

\section{CLOTHES-WASHING MACHINE.}

In all probability the public have been imposed on through the medium of a Clothes Washer to a greater extent than on any other article. In offering the Combination Washer we wish it distinctly understood that we guarantee this machine to work easier and to do better work than any other in the market.

We allow a trial of 30 days, and then if the Washer is unsatisfactory it may be returned at our expense. Circulars mailed on application.

Net cash price

$\$ 6.00$ each.

See Special Offers on third page of cover. 


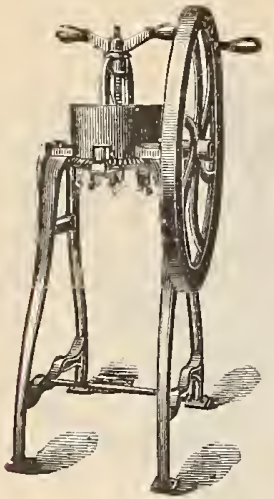

\section{MANN'S BONE CUTTER.}

After long and severe tests, the manufacturer has been enabled to eliminate all the weak parts in this bone cutter, and has thoroughly improved it in every respect. We are now ready to place in the hands of farmers and poultry fanciers a durable and thoroughly practical cutter for utilizing the bones from the market for poultry food. $\Lambda$ man can cut up with this hand cutter from fifteen to twenty-five pounds of green bones an hour.

\section{No. Price List.}

2 Standard bone cutter

6 Post bone cutter

8 Double hand cutter

Small power cutter

14 Large power cutter

16 Made to order

Fully illustrated. Descriptive price-list on application.

\begin{tabular}{ccrr} 
Weight. & Boxed. & List. & \multicolumn{1}{c}{ Net. } \\
I32 & 164 & $\$ 23.00$ & $\$ 18.40$ \\
IOI & 134 & 20.00 & 16.00 \\
180 & 212 & 28.00 & 22.40 \\
174 & 204 & 32.50 & 25.00 \\
374 & & 96.00 & 76.80 \\
6 I0 & & 280.00 & 224.90
\end{tabular}

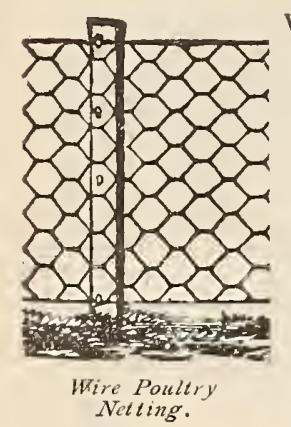

WIRE POULTRY NETTING.

We carry the following widths in stock : $12,18,24,30$, $36,42,48$, 6o and 72 inches. Each roll contains 150 running feet. For full rolls, net price, $5 / 8$ cent per square foot; for less than full roll, net price, I cent per square foot.

Above price applies to No. 19, 2-inch mesh netting only.

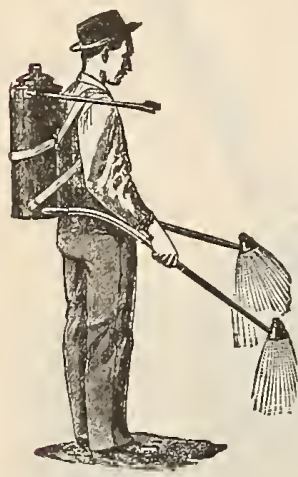

\section{CHAMPION PARIS GREEN SPRINKLER.}

Warranted to do the work of four men, and give entire satisfaction. Will sprinkle two rows at a time. No headache or sore throat in using Paris Green with this sprinkler.

Price, $\$ 3.75$ each.

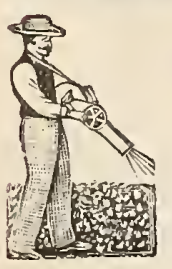

\section{THE CYCLONE EXTERIMINATOR.}

This machine will be found valuable in all sections of the country in destroying insect pests. One trial will prove its utility.

Price, \$6.0o.
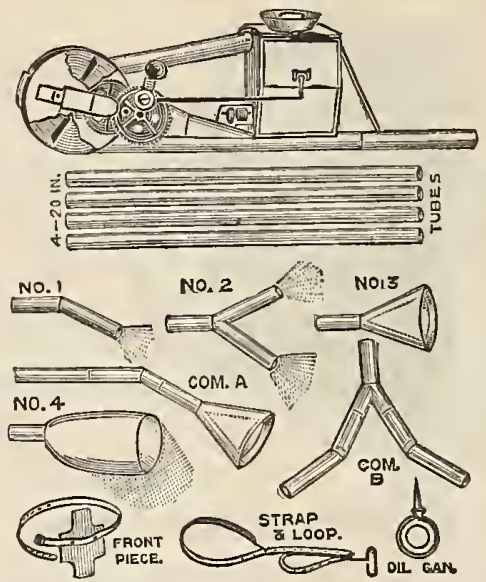

Patented Jan. I7, I888. Feb. 25, I890. Jan. 2. I 894 . Other Patents Pending.

\section{LEGGETT'S PARIS GREEN OR DRY POWDER GUN.}

The distribution of the powder can be so easily regulated that a half pound or a pound of Pure Paris Green or London Purple may be evenly distributed orer an acre of Potatoes. By leaving only a slight opening in the slots at the bottom of the reservorr. the faintest smoke of powder can be forced from the gun.

Hellebore, Insect Powder, slug shot, flower of sulphur or lime can be distributed better and more economically than in any other way.

Price . $\$ 7.00$ each.

FARMERS' FA-

\section{DUTTON'S} ASBESTOS TORCH.

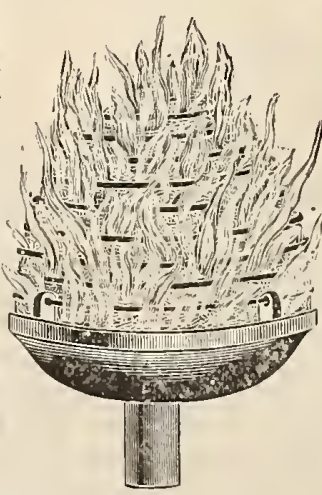
VORITE EXTERMINATOR.

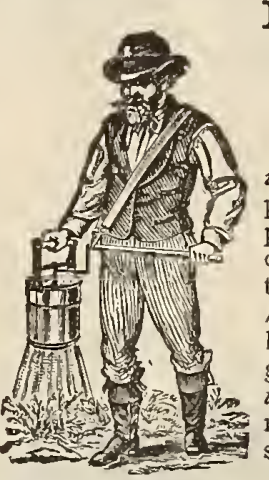

The best machine ever invented for applying poisons mixed with plaster, etc. A shower of $\mathrm{dust}$ is forced through, light or heavy, according to the length of the turn given; from eight to twenty-four inches may be covered as desired.

Price, $\$ 1.50$ each.

\section{SAVE YOUR TREES !}

DESTROY THE CATERPILLARS !

Saturate with kerosene oil, light, and hold under the caterpillars' nests, and pass quickly along the branches and around the trunk of the tree where the insects lodge. The great heat instantly destroys the insect, and will in no way injure the tree.

Price, 50 cents each.

\section{LAWN MOWERS OF ALL KINDS REPAIRED.} Send Machines to us early and avoid the rush. 


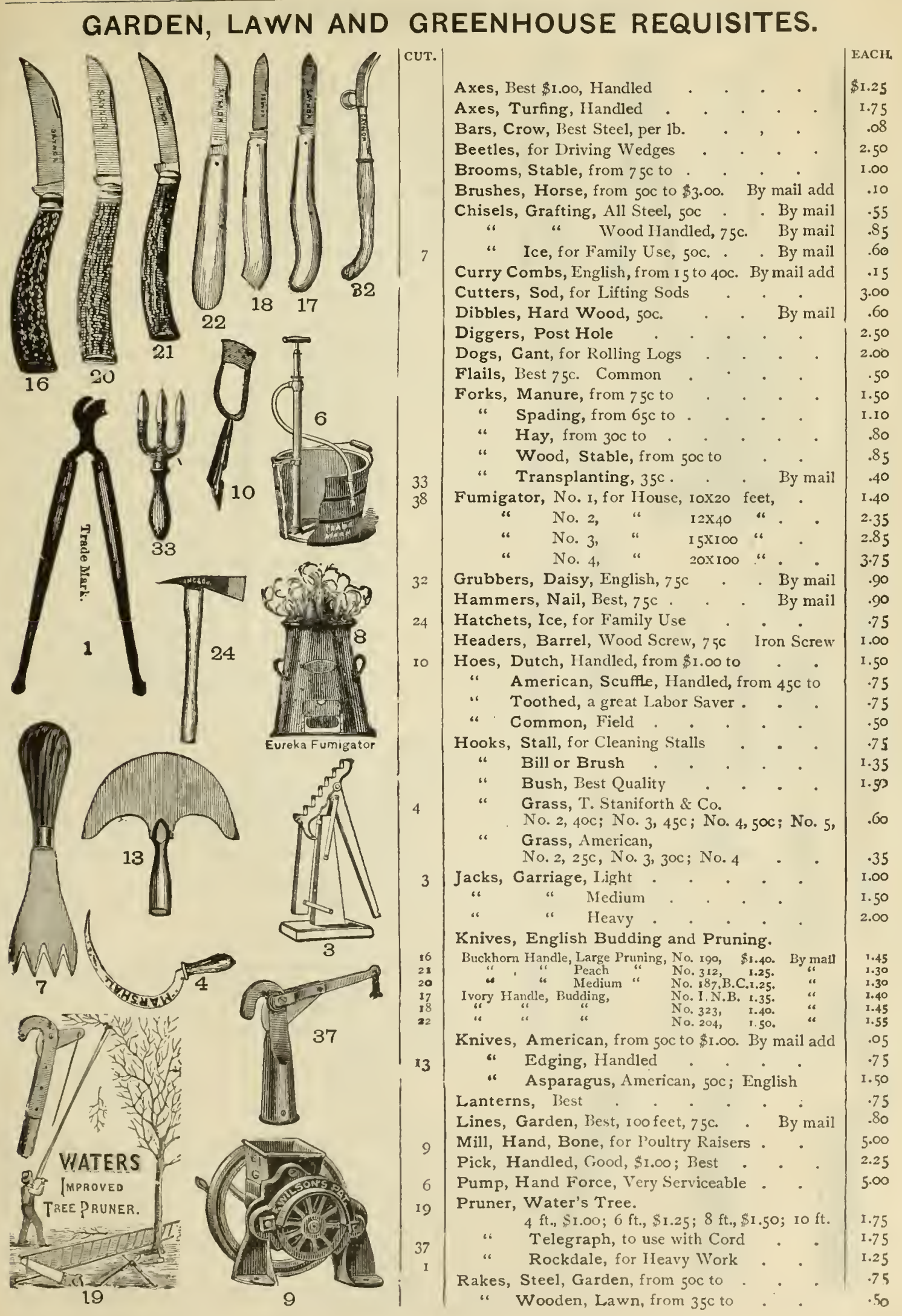

See Special Offers third page of cover. 


\section{GARDEN, LAWN AND GREENHOUSE REQUISITES.}
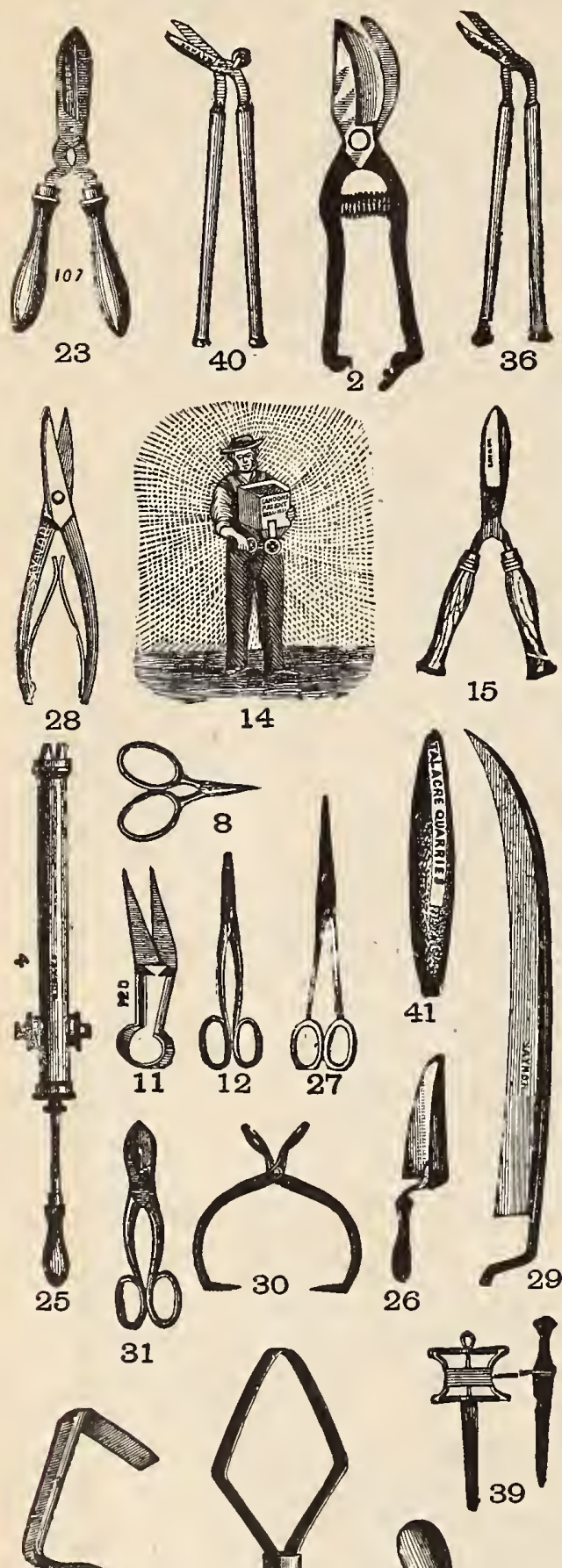

35

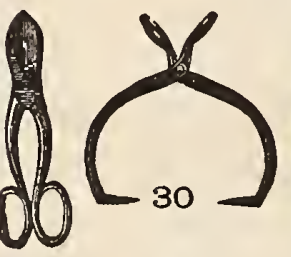

14

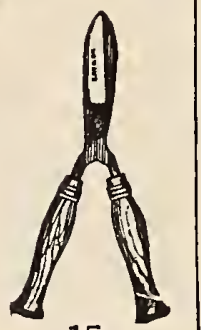

15
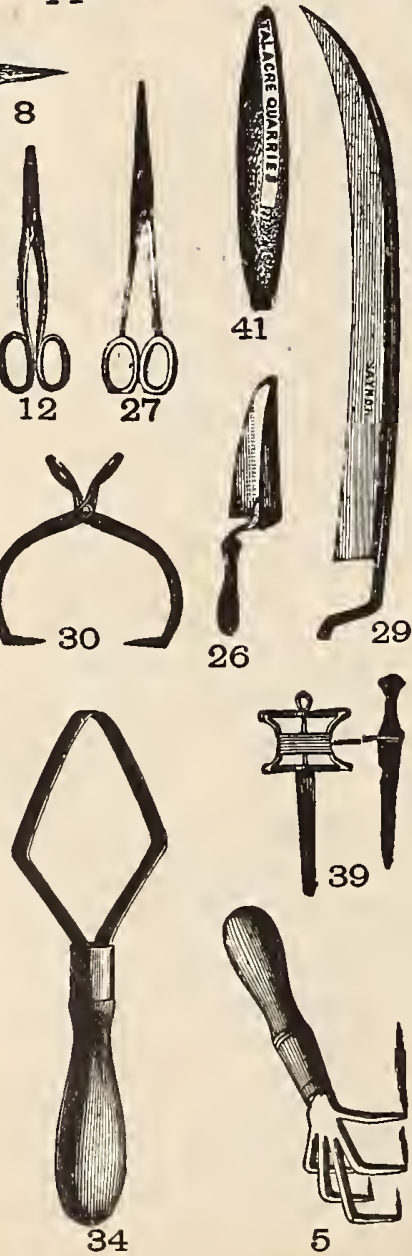

5

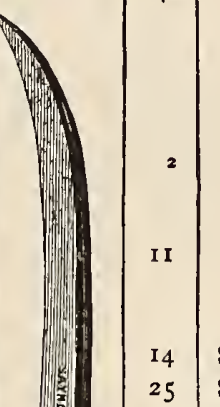

25

\section{son}

39

29

$4 \mathrm{I}$

27
12

31

8

28

I 5

23

36

40

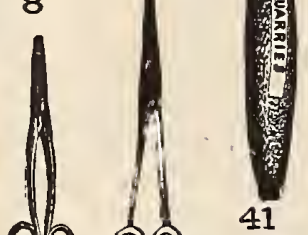

9

Fair quality for grass, $75 \mathrm{C}$. By mail

Syringes, Brass, English.

$16 \times 11 / 3$ in, No, 7 Jet and Rose

${ }^{18 \times 1} \times 1 / 2$ " No. $2^{1 / 2 .}$. Jet and Two Roses

${ }_{18 \times 1} 12 \times 1$ " No. 4 . Jet and Two Koses, Ball Valve and

18xi / No. 4. Jet and Two Koses, Ball Valve and 18xI $1 / 2$ in., No. 5. Jet and Two Roses, Ball $\dot{\text { Valve }}$ and I 4 Xn in. Ladies' Jet and Two Roses .

$18 \times 1 \frac{1}{2}$ " Ziuc, Brass Rose

Syringes, American.

I8xi I-2 in., Extra Heavy Tin

$\mathrm{I}$ 2XI in., Brass Jet and Rose .

Shovels, Ames' Best, Square, \$1.oo, Round .

“ Good Quality, Square, $75 \mathrm{c}$, Round

Spades, Ames' Best, $\$ 1.00$, good quality

Sprinklers, Revolving Lawn, 75c. . By mail Thermometers.

Tin Case, 7 in., $15 c$; 8 in., 20c; Io in., $25 \mathrm{c}$; 12 in., $30 c$. . . . By mail add

Dairy, all glass, $25 \mathrm{C}$. . . . By mail

Tongs, Ice, for Family use . . . .

Trowels, Steel Blade, Riveted Shank, 5 in., I $5 c$; 6in., 20c; 7 in., 20c; 8 in., 25c. By mail add

Trowels, Best Steel Welded Shank, 6 in., $40 \mathrm{c}$; 7 in., 5oc; 8 in., 6oc. . . . By mail add EACH $\$ .75$

.50

.75

.70

1.00

.85

.75

.25

.ro

.05

.05

.10

.80

.80

2.25

2.50

I. 60

3.50

4.50

.60

.10

.ro

I. 65

.90

4.00

$4, \infty$

6.00

8.00

9.00

3.00
1.25

.75

2.00

1.25

1.00

Weeders, Hand.

Haseltine, 25c. . . . . . By mail .30

Noyes, $25 \mathrm{c}$. . . . Bymail .30

Excelsior, 20c. . . . . . By mail .25

See Special Offers third page of cover. 


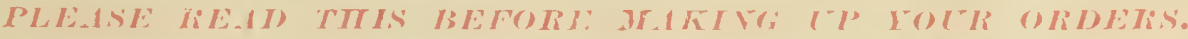

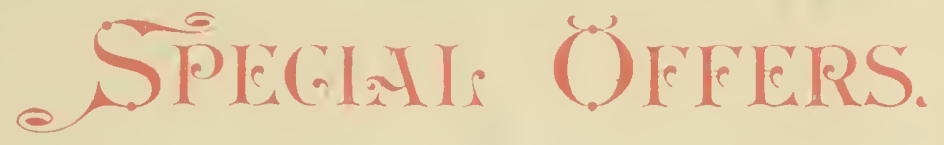

MAIL, EXPRESS, OR FREIGHT CHARGES PREPAID.

We mate the following offers on all orders mude up from our ANNTAL CATALOGIE FOR 1SOA, at the net rush prices therein stuterl (except as notell). SENT IS BI MAIL OR EATIESS, ACCOMPANIED BF CASII.

OFFEK IO. I.

We will send the GWODS PREPAID by Mail, Express, or

Frcight, as uc may deem arlvisable, TO ANT CITI OR, TOWN

I.T THE UNTTED STATES.

OFEER NO. 2.

On rill order's WHERE CUSTOMERS PAY TRANSPORTA-

THOY CIIARGES THEMSELTES wc will allow A DISCOUNT

OF TEN PEIR CENT.

\section{PLEASE REMEMIBER.}

That order's sent in erily SECURE TIIE FIRST SELECTIONS.

That our SPECIAL OFFERS ure POSITIVELI LIMITED to ORDERS IF IAIL or EIPRESS ACCOMPANTED BY CASH, postal note, Iraft on New York or Buston, stumps, express or post-oflicc money ordcr.

THAT these spccial offers BRING TO THE TOWN OR CITY OF THE PUTCILASEIR the choicest stocks of "WTERITHIVG FOR THE FAIII, GAIRDEN, ANT) LAWN", AT TUE SAME LOW IRICES AT WIICII WE SELL THEM IN BOSTON.

That our PATRONS WIO TAKE ADTANTAGE of thcse special offers MAF FELI ASSURED of having TUEIR ORDERS FILLED PRO.MITI HITI GOODS OF THE HIGIEST EXCELLENCE.

Thut our PRICES ASIDE FROMT SPECIAL OFFERS Will COMI'ARE FAITORABLI with those of ANI other REPUTABLE HOUSE in the Triterl states.

Thut we cun afford to offer such extraordinary inducencents for orlers scnt us by mail or express, accomprenied by cresh, becruse u'e cren execute thrm in the quiet of our mail order lepartment with promptness and respatch, and increase the volume of our business without impairing the efficiency of its service.

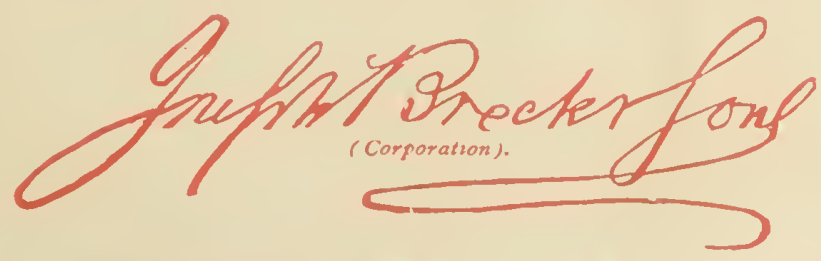




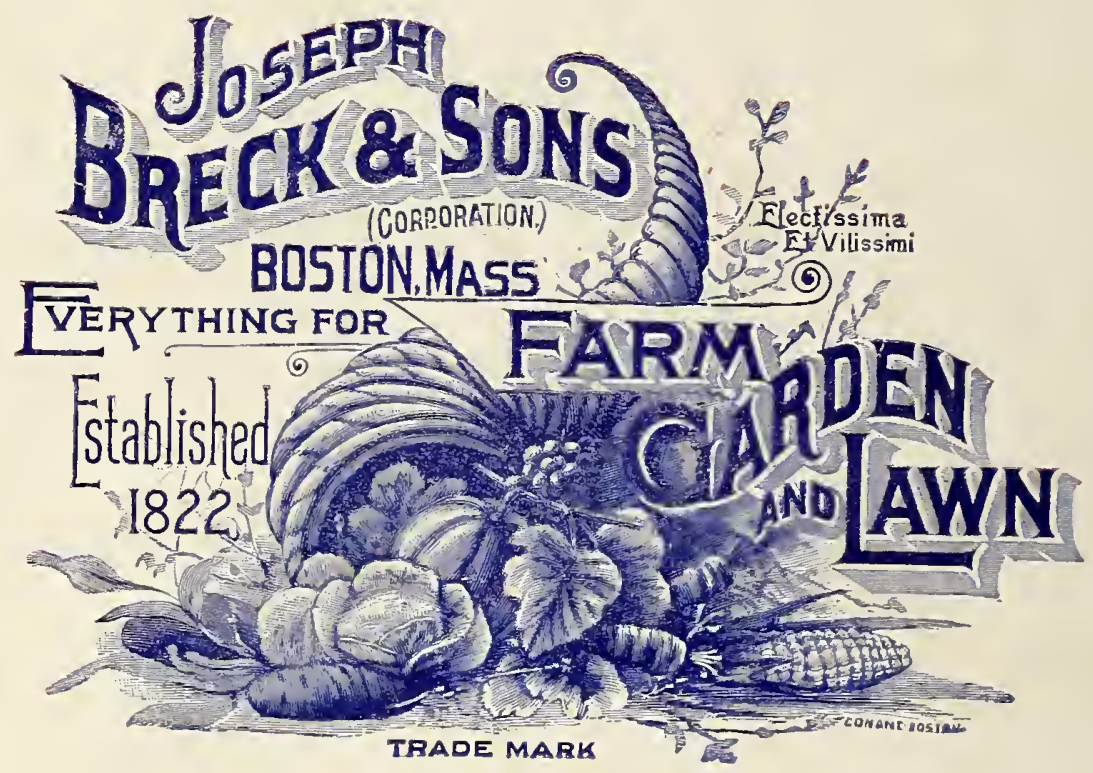

